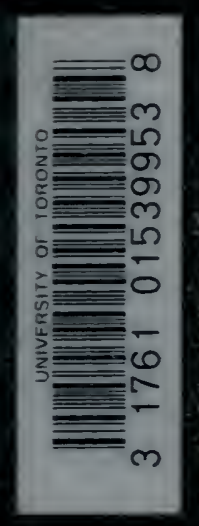

ofycol

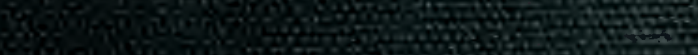

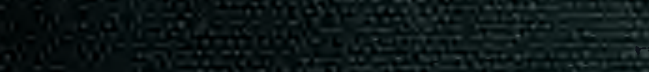

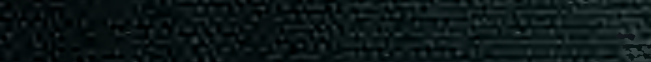
Wa

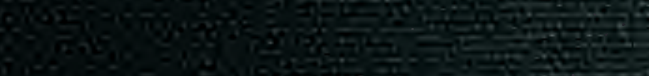

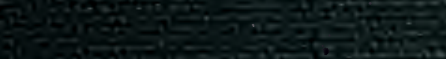

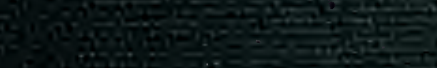

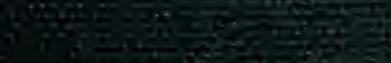






\title{
Farm Weeds of Canada
}

BY

\author{
GEORGE H. CLARK, B.S.A., \\ AND
}

JAMES FLETCHER, LL.D., F.R.S.C., F.L.S.,

With Illustrations by Norman Criddle

SECOND EDITION

Revised and Enlarged by George H. Clark

Published by Direction of

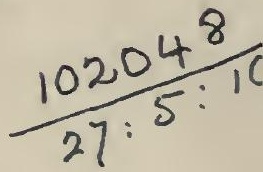

The Hon. Sydney A. Fisher, Minister of Agriculture, Ottawa, 1909

.FOR SALE, BY SINGLE COPIES ONLY,

AT THE OFFICE OF

THE SUPERINTENDENT OF STATIONERY, GOVERNMENT PRINTING BUREAU, OTTAWA.

Price $\$ 1.00$. 


$$
\begin{aligned}
& S B \\
& 613 \\
& C 2 A 4 \\
& 1923 \\
& \text { cop.2 }
\end{aligned}
$$




\section{TABLE OF CONTENTS}

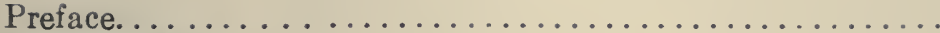

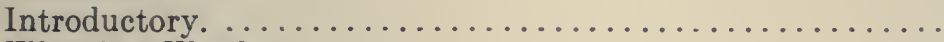

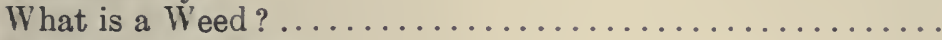

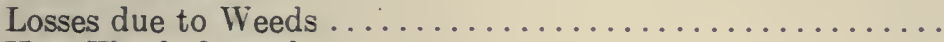

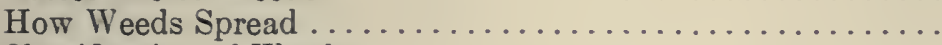

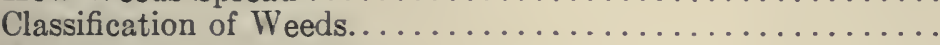

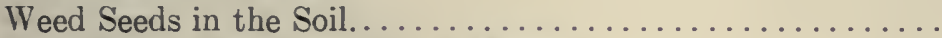

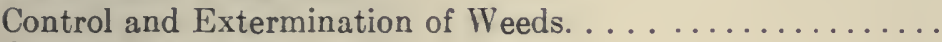

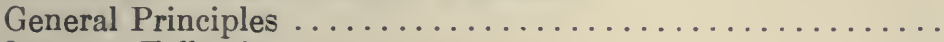

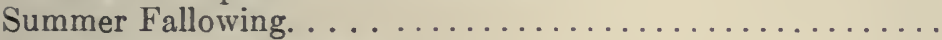

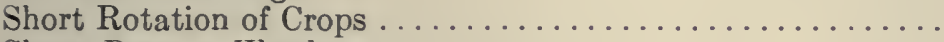

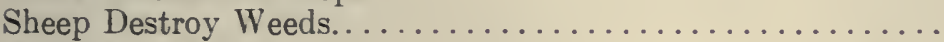

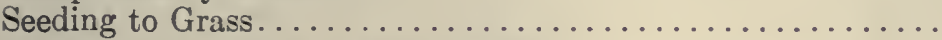

Farm Implements to Destroy Weeds .................

Weed Seeds in Commercial Seeds and Feeding Stuffs ........

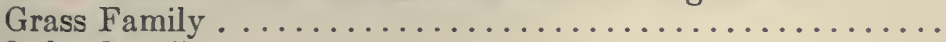

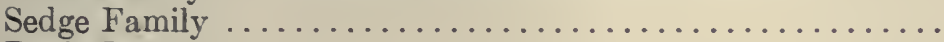

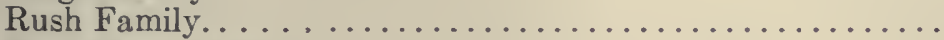

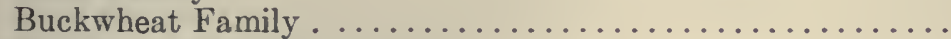

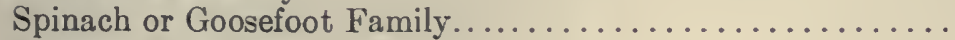

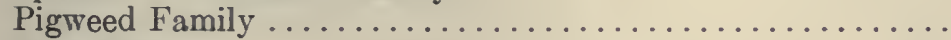

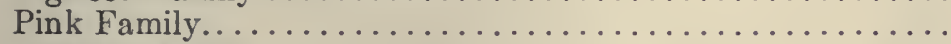

Purslane Family. . . . . . . . . . . . . . . . . . . .

Buttercup Family . . . . . . . . . . . . . . . . . . . . .

Fumitory Family. . . . . . . . . .

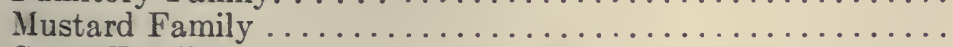

Caper Family

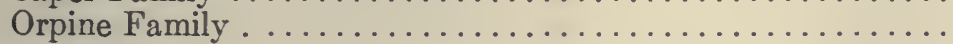

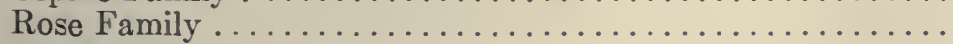

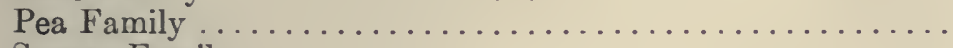

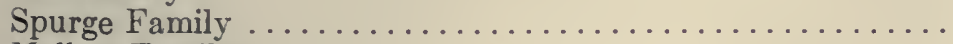

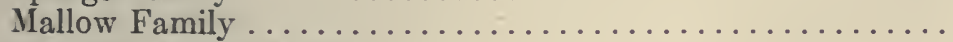

St. John's-wort Family . . . . . . . . . . . . . . . . .

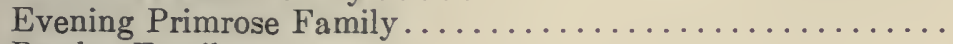

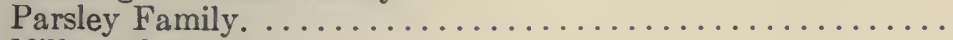

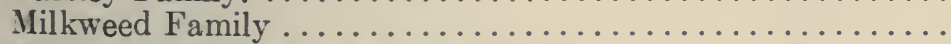

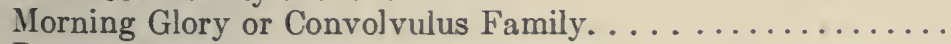

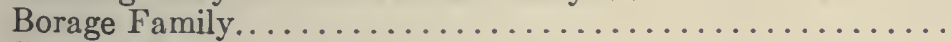

Vervain Family . . . . . . . . . . . . . . . . . . .

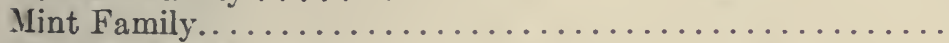

Figwort Family

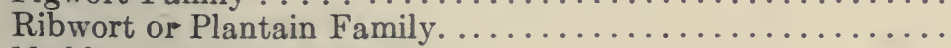

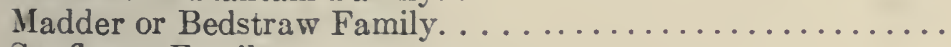

Sunflower Family. . . . . . . . . . . . . . . . . . . . . . .

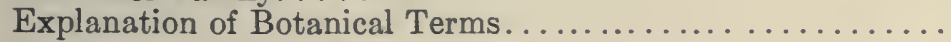

Index. 



\section{PREFACE}

The first edition of "Farm Weeds of Canada" was distributed free to public libraries, universities, colleges, high schools, rural schools, agricultural societies and farmers' institutes and clubs. The book was designed to stimulate interest in the study of farm weeds in general, their habits of growth and the best methods of combating them. It was distributed with a view to make it conveniently available for the purpose of reference, to all who are interested in agricultural pursuits but particularly to farmers and pupils of schools in farming districts.

The second edition has been prepared and published to meet the urgent requests from individuals who desire the book for their personal use. The information presented in the text is useful because the illustrations of weeds and weed seeds make it intelligible to farmers and others who are not expert in the nomenclature of plants. The expense entailed in the preparation, printing and binding of seventysix coloured plates as contained in this volume precludes it from the list of those publications of the Department of Agriculture that are distributed generally and free of charge. The nominal price fixed for its sale will restrict its distribution to those who will preserve and make proper use of it, and will meet a part of the unusual expense incurred in its issue.

The death of Dr. James Fletcher, co-editor of the first edition, caused a temporary suspension of the plans for the publication of the second edition. With his co-operation and supervision, a large number of water colour sketches of weeds were made by Norman Criddle, while employed by the Seed Branch, during the early summer of 1908 . From these sketches selections were made of the illustrations of weeds and weed seeds for the 20 additional plates that are included in the second edition. The tentative general plans for the enlargement, botanical re-arrangement and revision of text for a new edition of "Farm Weeds" had been discussed with Dr. Fletcher in a general way on several occasions during 1907 and the winter and early spring of 1908. It is believed that the nature of the revision is in accord with the views which he held and with the spirit of progressiveness that is clearly evident in all his life work.

Considerable re-arrangement of the matter was made necessary in the second edition in order that the various plant families, genera and species might be adjusted to conform with the recommendations of the International Botanical Congress at Vienna and now generally adopted by botanists. Some additions to the subject matter have been made to include new and important information that has resulted from recent research work. In revising the descriptions of plants and seeds technical terms have been avoided whenever possible.

The book is not intended for use as a text book of botany. Inasmuch as the primary object of its issue is to present information per- 
taining only to those plants that are commonly characterized as weeds, it will be obvious that several plant families of importance in the study of the science of botany, are not treated with in this publication. Nor has it seemed practicable to illustrate, describe or even mention more than those species that are known to be quite widely distributed and generally troublesome weeds in Canada.

Some of the weeds herein illustrated and described have been introduced within recent years, and it is to be expected that many others and equally troublesome weeds may be introduced from time to time and distributed in future years. Additional information concerning weeds and methods of combating them will doubtless also accrue from further research work. It is thought reasonable to expect that later revised editions of "Farm Weeds" may be necessary to bring it up to date for future years.

"Farm Weeds of Canada" was one of the last of the many contributions to agriculture from the late Dr. James Fletcher. It is desired that this second edition of the book will further perpetuate to his memory that large measure of appreciation of his unselfish personality and zeal for useful service which he so richly deserved.

Recognition for much arduous detail work in the compilation and revision of the descriptions of weeds and weed seeds as contained in this volume is due to Mr. George Michaud, Botanist in charge of the Seed Laboratory. Valuable assistance was rendered by Prof. John Macoun, who was frequently consulted in connection with the work of re-classification and botanical nomenclature. Information as to the best methods that may be employed in the control and extermination of particular weeds was provided by many experts in the practice of agriculture, among them being T. G. Raynor, W. C. McKillican, J. H. Grisdale, Henry Glendenning, T. N. Willing, T. B. R. Henderson, Angus MacKay, S. A. Bedford, James Murray, W. H. Fairfield and Archibald Mitchel.

The illustrations of farm implements to destroy weeds were selected with a view to show the type of implements referred to in the text. There are numerous implements of approximately the same general type, but of somewhat different design, which are equally desirable and effective as weed destroyers.

Numerous quotations from old writings which treat with farm weeds and other plants are inserted in space not required for the principal text. The quotations from Tusser, Grahame, Jethro Tull, Sinclair, Dickson, Worlidge, Fitzherberts, Hale and Blith were contributed by Principal R. Patrick Wright, Glasgow, Scotland, and R. B. Greig, Marischal College, Aberdeen, Scotland. The subject matter as well as the text itself of many of the oldest of the quotations will doubtless prove interesting and some of them even instructive when studied in relation to the subject matter of this volume. They may convey to the mind of the reader a fairly clear idea of the general knowledge of plants that was possessed by the students of the natural sciences in past centuries.

S. A. F.

G. H. C. 


\section{FARM WEEDS OF CANADA.}

\section{INTRODUCTORY.}

The annual losses due to the occurrence of pernicious weeds upon farm lands, although acknowledged in a general way, are far greater than is realized. These losses can be appreciably lessened, however, by treatment based upon an accurate knowledge of the nature of each weed.

Most farmers give little critical attention to the weeds growing among their crops. Some think that, because many of these plants are unfamiliar, the exact recognition of all of them is impossible. This, however, is not the case, and, as the different kinds vary greatly in their power of robbing the farmer, it is certainly advisable that more attention should be given to weed pests. Although several hundred kinds of plants grow wild in almost every locality, and many of these may appear among cultivated crops, comparatively few give serious trouble -not more than there are different kinds of crops grownand every cultivator of the soil knows the difference between wheat, barley, oats, rye, peas, turnips, beets, etc. It is no more difficult to learn the names, nature and appearance of Stinkweed, Hare's-ear Mustard, False Flax, Canada Thistle, Field Sow Thistle, Sweet Grass, Quack, etc., than to recognize the familiar cultivated plants.

In the official bulletins which have been widely distributed during recent years, the weeds have been named uniformly, though many of them have other local names. It is therefore clearly important that those for whose benefit the bulletins have been prepared should know the plants by the names officially recognized, so that they may be able to make the fullest use of the information. 
The prevalence of some species of weeds in certain parts of the Dominion must be viewed with the gravest alarm, for they have taken such possession of the land as to seriously affect profitable farming. Such aggressive enemies are: Wild Mustard, Quack or Couch Grass and Canada Thistle in parts of almost every province; Ox-eye Daisy in the Maritime Provinees; Field Sow Thistle in the Maritime Provinces, Quebec, Ontario, and the Red River Valley in Manitoba; and Stinkweed or Penny Cress, Ball Mustard and Hare's-ear Mustard in all the Prairie Provinces.

The increase of weeds is frequently due to the fact that through ignorance of their noxious nature and power to spread, farmers have neglected them.

"Many of our farmers have only a limited knowledge of weeds, and in many cases do not recognize those that are dangerous on their first appearance. Hence we have 'One year's seeding, seven years' weeding.' There are some weeds so noxious that if farmers knew their real character and recognized the plants on their first appearance, they would postpone all other business until they were destroyed. . . Self-interest should be a sufficient incentive to farmers to destroy weeds if it is clearly shown that it will pay them to do so."-H. Mackellar.

WHAT IS A WEED?

There are many definitions of the word, but perhaps from a farmer's standpoint the best one is, "Any injurious, troublesome or unsightly plant that is at the same time useless or comparatively so." As a general statement, it may be said that our most troublesome and aggressive weeds have been introduced into Canada from other countries; but it is also true that, under special circumstances, some of our native wild plants may increase and become "noxious weeds."

LOSSES DUE TO WEEDS.

It is impossible to determine accurately the losses to the individual farmer, or to an agricultural district or country 
as a whole, from weeds growing upon cultivated land. In various ways they lower the yield, depreciate the quality and value of crops, and add to the cost of production.

1. Weeds rob the soil of plant food and of moisture, thus increasing the effects of drought by taking up water from the soil and wasting it by evaporation.

2. Weeds crowd out more useful plants, being hardier and, as a rule, more prolific.

3. Weeds are a source of expense. From the time farmers begin to prepare their land for a crop, these enemies increase the cost of every operation-of plowing, harrowing, seeding cultivating, cutting, binding, carrying and threshing, as well as in cleaning, freighting and marketing the produce. Direct losses are the larger consumption of binder twine necessary when weedy crops are harvested, the extra wear and tear on machinery due to coarse-growing weeds, and the depreciation in the market value of the crop because of the presence of weeds in hay or of weed seeds in grain.

4. The eradication of the worst weeds is costly in labour, time and machinery, and frequently prevents a farmer from following the best crop rotation, or even compels him to grow crops which are less advantageous.

5. Many weeds are conspicuous and all are unsightly on farm lands. They thus, in a varying degree, according to their several natures, depreciate the value of land.

6. Some weeds are harmful to stock, being poisonous, as Water Hemlock; others are injurious to their products, as burs in wool, or Wild Garlic and Stinkweed, which taint milk. The horny or barbed seeds of some grasses, as Porcupine Grass and Skunk-tail Grass in the Northwest, cause irritation or painful wounds by penetrating the flesh, particularly the mouth parts.

7. Weeds attract injurious insects and harbour fungus diseases. Weedy stubbles or summer-fallows are breeding 
grounds for cut-worms, and the rust of small grains may pass the winter on several kinds of grasses.

\section{HOW WEEDS SPREAD.}

In the present age of easy communieation with all parts of the country, and indeed with the whole world, there are frequent opportunities for the introduction of weed seeds into previously uninfested districts.

1. By natural agencies. The wind carries seeds long distances, not only in summer, but with drifting soil and over the surface of the snow in winter. Streams distribute them along their eourses. They are also distributed by seed-eating birds and herbivorous animals, through the stomachs of which the seeds pass undigested; or they attach themselves by special contrivances, such as hooked and barbed hairs, spines, gummy exeretions, ete., to passing animals.

2. By human agencies. New weeds are introduced on farms with grass, elover or other commercial seeds, and commercial feeding stuffs usually eontain some vital weed seeds. They are spread from district to district through various transportation facilities, such as railways, and beeome disseminated within a locality in stable manure from towns and cities, and through threshing machines and farm implements. The illustrations of weed seeds on the last five plates of this volume will aid in the identification of impurities common in commercial seeds and feeding stuffs.

\section{CLASSIFICATION OF WEEDS.}

Weeds, like all other plants, may be classified, according to the length of time they live, as anuuals, or one-year plants; biennials, or two-year plants; and perennials, or many-year plants. In eradicating weeds, it is of the greatest importance to ascertain under which of these heads they come, because the treatment is usually to prevent annuals and biennials from seeding and perennials from forming new leaves, roots and underground stems. 
Annuals complete their growth in a year. As a rule, they have small fibrous roots and produce a large quantity of seed. Examples of this class are Wild Mustard, Lamb's Quarters, Wild Buckwheat, Purslane, Ragweed and Wild Oats. Some weeds, called Winter Annuals, are true annuals when the seeds germinate in the spring, but they are also biennial in habit; that is, their seeds ripen in the summer, fall to the ground, germinate and produce a certain growth before winter sets in, and then complete their development the next spring. Of these may be mentioned Shepherd's Purse, Peppergrass, Stinkweed, Wormseed Mustard, Ball Mustard, Hare's-ear Mustard, Canada Fleabane and Blue Bur.

Biennials require two seasons to complete their growth, the first being spent in collecting and storing up a supply of nourishment, which is used the second season in producing flowers and seeds. Examples of these are Burdock, False Tansy, Common Evening Primrose and Viper's Bugloss or Blueweed.

Perennials are those plants which continue to grow for many years. Perennial weeds are propagated in several ways, but all produce seeds as well. They have two distinct modes of growth; some root deeply, while with others the root system is near the surface. The most troublesome are those which extend long underground stems or rootstocks beneath the surface of the ground, as Canada Thistle, Perennial or Field Sow Thistle, Field Bindweed, Bladder Campion, White-stemmed Evening Primrose, Blue Lettuce and some wild sunflowers. Representatives of the second class or shallow-rooted perennials are Pasture Sage, Yarrow and Couch Grass. Some perennials extend but slowly from the root by short stems or offsets, but produce a large quantity of seed. Of these, Ox-eye Daisy, Dandelion, Goldenrod and Yarrow are examples.

Weeds might also be grouped, according to their manıer of distribution, into two general classes:-

a. Weeds distributed in time are those which, when mature, discharge their seed close to the mother plant. The seeds of 
such weeds as the mustards, cockles and pigweeds, when fresh, possess a protective coat that is almost impervious to water. As a rule, the seeds of such weeds retain their vitality for a number of years and germinate only when the hard seed coat has become disintegrated by continued exposure to the action of the sun, air or other climatic or soil conditions. Thus are such weeds naturally distributed in time.

b. Weeds distributed in space are those the seeds of which, when mature, are provided with means for natural distribution by wind or other agencies. The thistles, hawkweeds and dandelions are examples of weeds distributed in space. The seeds of such weeds, as a rule, do not retain their vitality for more than a few years.

\section{WEED SEEDS IN THE SOIL.}

The ability of the seeds of many species of plants to retain their vitality when embedded in the soil for a period of years is one of the principal factors which brings them within the category of noxious weeds.

It is commonly asserted by farmers that seeds of several species of the Mustard and other families will retain their vitality for an indefinite period. The apparent absence of mustard in old pastures, roadways or lands left waste during many years, and the re-appearance of the plant when the land is brought under cultivation, forms the usual evidence to bear out such assertions. An examination of permanent pasture or waste lands that are known to have been polluted with mustard will, however, show occasional inconspicuous plants that give promise of ripening a few seeds.

Duval, of Washington, D.C., in December, 1902, buried 112 different kinds of seeds in clay soil in earthen pots, to depths of six, eighteen and thirty-six inches, and compared their vitality with control samples kept in proper storage. When dug up in November, 1903, practically all the seeds of cultivated plants were decayed, many of them having first germinated, even at 
a depth of thirty-six inches. The buried weed seeds showed a decided loss of vitality when compared with the control samples that were kept in storage. The latter germinated fifty-three per cent. on the average; those buried to a depth of six inches germinated twenty per cent.; eighteen inches, twenty-six per cent.; and thirty-six inches, thirty-one per cent.

Ewart, of the University of Melbourne, Australia, made exhaustive vitality tests of six hundred different species of seeds taken from a collection that had been compiled and stored in a dry, airy and dark cupboard by Prof. McCoy in 1856, and a large number of specimens of seeds, of varying ages, from the national herbarium and other reliable sources. In his deductions from the results of over 3,000 tests, Ewart gives a list of those relatively few species that may be expected, under favourable conditions, to retain their vitality beyond fifteen years, nearly all of which species are included in the following botanical families: Leguminosae, Malvaceae, Myrtaceae, Nymphaeaceae, Labiatae and Irideae. Forty-eight specimens of seeds of the genus Brassica (the Mustard family) were tested. The fresh seeds gave a germination as high as eighty-six per cent. and one lot twelve years old gave a germination of thirty per cent. None of the Brassica samples fifteen years old or more germinated, although six of them were less than twenty years old.

CONTRUL AND EXTERMINATION OF WEEDS.

In adopting a method of extermination, the nature of the plant and its habits of growth must first of all be considered. Some experience is necessary to know the best time to work certain soils or to deal with special weeds, as well as to recognize them in all their stages. Some weeds, Russian Thistle and Stinkweed, for instance, have a very different appearance when young and when mature. No general rule can be given, as the treatment must vary with different districts, different soils, and different climatic conditions. What may be successful in one place may fail in another. 
Annuals may be cradicated from land, however badly infested it may be, through any method by which germination is hastened and the young plants destroyed before they produce seed.

Biennials must be either plowed or cut down before they flower. Mowing at short intervals in the second year, so as to prevent the development of new seeds, will clear the land of this elass of plants; but a single mowing will only induce them to send out later branches, which, if not eut, will mature many seeds. Where plowing is impracticable, such plants should be eut off below the crown of the root.

Perennials are by far the most troublesome of all weeds and require thorough treatment, in some instances the cultivation of special crops, to insure their eradication. Imperfect treatment, such as a single plowing, often does more harm than good, by breaking up the rootstocks and stimulating growth.

For shallow-rooted perennials, infested land should be plowed so lightly that the roots are exposed to the sun to dry up. For deep-rooted perennials, on the other hand, plowing should be as deep as conveniently possible. The nature of the land must determine the depth of plowing. In light or gravelly soils shallow plowing may be preferable as deep plowing might interfere with the mechanical texture of the soil, which is so important in the storing of moisture.

The rootstocks of some perennial weeds are very persistent. Small sections or cuttings from them will quickly take root when they are distributed by plowing or cultivation. Where such persistent perennials have become well established, it is usually advisable to adopt the most convenient method of cultivation that will bring the rootstocks to the surface. They should then be gathered and burnt or otherwise destroyed. Most perennial weeds will, however, suceumb to continued thorough cultivation that will prevent the growth of leaves.

Plants take in most of their food through their leaves. Perennial plants, which live for many years, have special reser- 
voirs where some of this food, after elaboration, is stored in such receptacles as bulbs, tubers and fleshy rootstocks. The first growth in spring, particularly flowering stems, is produced mainly by drawing on this special store of nourishment. Plants are therefore in their weakest condition when they have largely exhausted their reserve supply of food and have not had time to replenish it. The stage of growth, then, when plowing will be most effective is when their flowering stems have made full growth but before the seeds, which would be a source of danger, have had time to mature.

GENERAL PRINCIPLES.

1. There is no weed known which can not be eradicated by constant attention, if the nature of its growth be understood.

2. Never allow weeds to ripen seeds.

3. Cultivate frequently, particularly early in the season, so as to destroy seedlings.

4. Many weed seeds can be induced to germinate in autumn by cultivating stubbles immediately after harvest. Most of these seedlings will be winter-killed or can be easily disposed of by plowing or cultivation in spring.

5. All weeds bearing mature seeds should be burnt. Under no circumstances should they be plowed under.

6. All weeds can be destroyed by the use of ordinary implements of the farm, the plow, the cultivator, the harrow, the spud and the hoe.

7. Be constantly on the alert to prevent new weeds from becoming established.

SUMMER FALLOWING.

The practice of summer-fallowing land, to the exclusion of all crops throughout the season, whatever may be said against it, affords the best opportunity to suppress noxious weeds. For 
lands foul with persistent growing perennials, a thorough summer-fallow will usually be the most effective and, in the end, the least expensive method of bringing the weeds under control.

The amount and nature of the cultivation of a summerfallow will depend on the habits of the weeds, the kind of soil, and the climatic conditions. In some extreme cases of perennial weeds, it may be advisable to allow the plants to exhaust their reserve vigor by growth until the flowers are formed, then cut and remove the surface growth, plow to a depth of four or five inches, and bring the rootstocks to the surface befure they have had time to renew growth. After cutting and removing the surface growth cultivators may, after several applications, be forced to the bottom of the furrow, thus unearthing the network of rootstocks. Much machine labour in working out and destroying the rootstocks before they have had time to renew growth after the first plowing will be most economical in the end. Perennial weeds having deep rootstocks may require a second and deep plowing before all the underground vegetation can be unearthed. If perennials alone are to be dealt with, they may be treated as above directly after an early hay crop.

Periodical cultivation of the summer-fallow throughout the growing season is effective in bringing weed seeds to the surface, stimulating their germination and destroying the secdling plants. When the destruction of annual weeds is the chief purpose of cultivation, deep plowing two or three times during the summer, with surface cultivation each week during June and July and less frequently later in the season, should secure the germination and destruction of the maximum number of seeds. On account of the soil and climate, one plowing of summer-fallow is favoured in the Prairie Provinces. In moist seasons a second decp plowing is apt to stimulate too rank a growth of straw and delay the ripening of the grain. The germination of weed seeds is stimulated most by cultivation during the early growing season, and summer-fallows intended primarily 
for that purpose should be brought under cultivation early in the season.

\section{SHORT ROTATION OF CROPS.}

To keep farms free from weeds, few methods give such good results as a systematic short rotation of crops, with regular seeding down to grass or clover at short intervals.

Weeds are most in evidence in districts where the production of cereal grains predominates and where the systematic alternation of crops is not generally practiced. Many weeds ripen their seeds with cereal grains and the seeds are scattered during harvest. When a cereal crop is followed by early clover, the weeds in the clover may be cut before they are mature. The hay crop of the second year after seeding is not infested with weeds because a fresh supply of the seeds has not been brought to the surface by cultivation. The removal of the hay crop of the second year affords an opportunity for a summerfallow, preparatory to the production of a hoed or some other cleaning crop.

The following short rotation is recommended for the eastern provinces by J. H. Grisdale, Agriculturist of the Central Experimental Farm:-

"To destroy weeds, probably the best rotation possible is one of three years duration including clover and mixed hay, followed by roots or corn, the land shallow-plowed in fall and sown to grain the next spring with ten pounds of red clover and twelve pounds of timothy per acre. (When the land is heavy or clayey, the ten pounds of red clover may be replaced by six pounds of red clover and two of alsike.) If a portion of the arable land must be used for pasture, then the land might be allowed to remain under grass or hay for two years instead of one year, the second being used for pasture, thus extending the threeyear into a four-year rotation. The pasture land in the fouryear rotation, or the hay land in the three-year rotation, should be broken up early in August and cultivated at intervals to destroy the successive growths of weeds as they appear. The 
land should be again plowed or preferably ridged in the fall. These rotations may be expected to give good results anywhere in Canada east of Manitoba."

\section{SHEEP DESTROY WEEDS.}

When an abundance of succulent pasture of the finer grasses is provided, weeds can scarcely be said to be favoured by sheep as a staple part of their diet. Sheep will, however, even when good pasture is provided them, vary their diet by nipping off seedling plants or the fresh growing parts, and the bloom with its content of sweets, from older plants of many of our common weeds. When their pasture is depleted, sheep feed readily on Wild Mustard, Ox-eye Daisy, Yarrow, Plantain, Perennial and Annual Sow Thistle, Wild Vetch or Tare, Docks, Sorrel, Lamb's Quarters, Milkweed, Ragwort, Burdock and Shepherd's Purse. In fact, there are few weeds that sheep will not eat, to the extent of preventing them from seeding, if there is not enough of their favorite grasses to satisfy them. It is only when the supply of food is unusually short that sheep will feed on plants having leaves and stems covered with bristly hairs or spines, or with a flavour that is obnoxious to them. When the plants are young and tender, however, sheep have been observed to eat such weeds as Ragweed, Blue-weed, Cockles, Orange Hawkweed, Hound's Tongue, Stickseed, Mullein, Canada Thistle, Stinkweed, Toadflax, and others that are bristly or have a pungent flavour. Thorough cultivation with a systematic rotation of crops, combined with the maintenance of as many sheep as can be kept to advantage, is a certain and profitable means of keeping weeds under control.

\section{SLEDING TO GRASS.}

Lands foul with some kinds of weeds, particularly annuals, may advantageously be seeded to grass for hay or pasture. The cultivation of hoed crops becomes too expensive for labour when the soil is polluted with weed seeds. Grain crops may also be unprofitable because of weeds, and they afford an oppor- 
tunity for the weeds to increase. A thorough summer-fallow would do much to bring the weeds under control, but this is not always convenient. Seeding to grass and cutting the hay crop early would prevent most kinds of weeds from ripening more than a relatively small number of seeds, and the number of vital weed seeds in the sub-surface soil would rapidly decrease from year to year. If perennial weeds are also prevalent, it would be well to pasture with sheep and mow the roughage closely each year, before the spring growth has formed seeds.

\section{FARM IMPLEMENTS TO DESTROY WEEDS.}

The best time to destroy weeds is within two or three days after the first pair of leaves has formed on the seedling plant. In friable soils the "weeder" is a useful implement. for that purpose. The "tilting" harrow is also satisfactory for comparatively loose soils and is preferred as a weed destroyer on firm or clayey land. Weeds are irregular in time of germination; consequently it is necessary to apply the weeder or harrow frequently throughout the growing season. Fields of potatoes, corn and cereal grains, when sown with a drill, may advantageously be treated with these weed destroyers once or twice before the crop distinctly shows above ground, and again, with corn and ordinary grain crops, when the plants are three to six

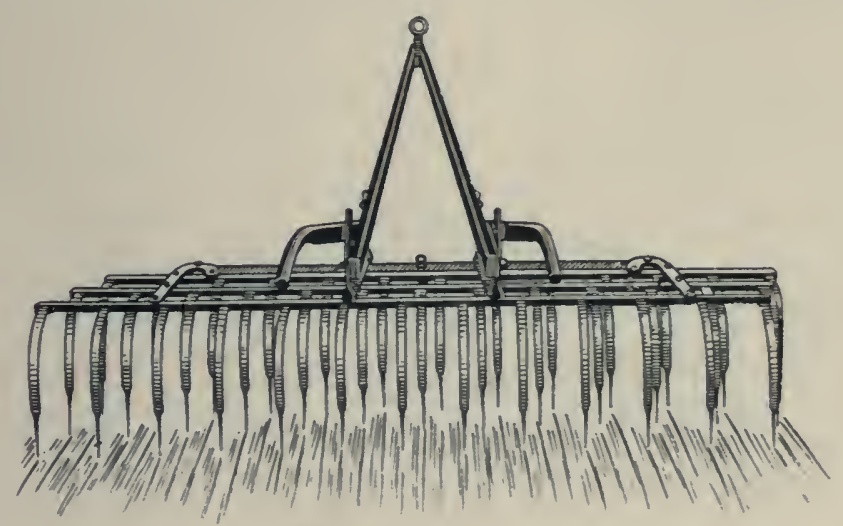

THE WEEDER 


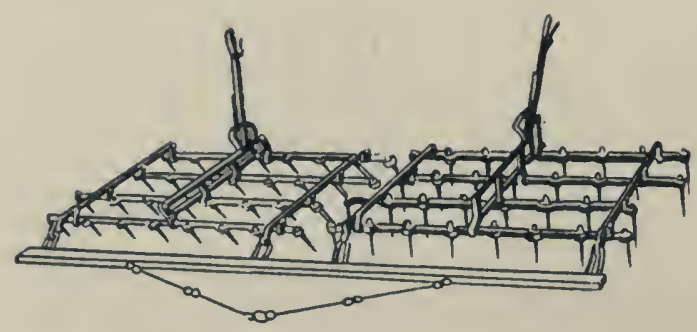

THE TILTING HARROW

inches high. Even relatively heavy harrows ordinarily in use will do little damage to the potatoes, corn or grain plants if the land is not wet, and the loosening of the surface soil benefits the crop in addition to the destruction of the weeds.

For perennial weeds, or seedlings that have become well rooted, a cultivator having "diamond" shaped or other relatively broad shares is needed for hoed crops. The "dise" is a favoured implement for destroying weeds in summer-fallow or in preparing a seed bed. When, however, it is desired to unearth and remove the rootstocks of perennial weeds such as Couch Grass, a narrow-toothed cultivator, that will loosen the soil and bring the underground vegetation to the surface, is preferred to an

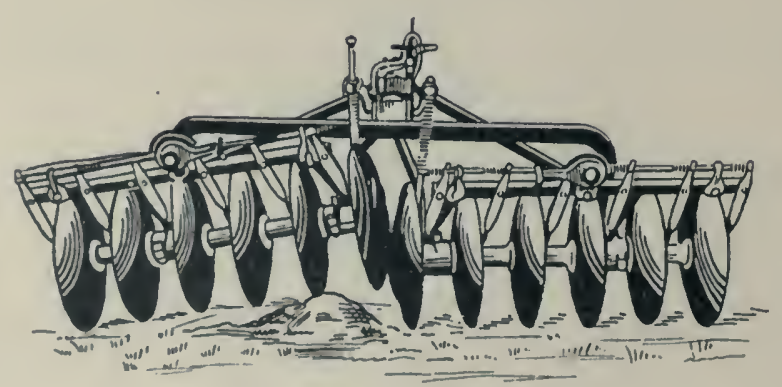

THE DISC 


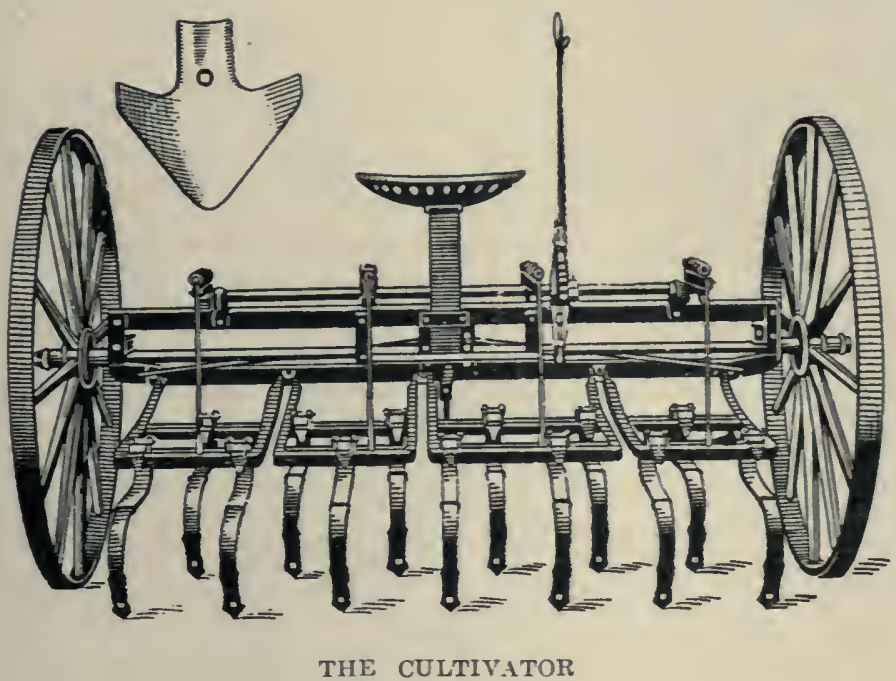

implement that will cut the rootstocks, the small cuttings of which may be exceedingly persistent in growth.

WEED SEEDS IN COMMERCIAL SEEDS AND FEEDING STUFFS.

Commercial seeds and feeding stuffs are fruitful sources of weed introduction and distribution. Stable manure from cities and towns is often polluted with weed seeds; but its distribution is not so general as the seeds of clovers, grasses and cereals or ground meal for feeding.

Too much care cannot be taken to procure clean seed. An additional cost of fifty cents per acre for seed known to be clean is cheap insurance against losses caused by the introduction of noxious weeds. Where possible, it is advisable to procure seed from lands that are known to be free from noxious weeds. Commercial seeds should be carefully examined and the kinds and nature of any weed seeds included therein clearly understood before they are sown. Absolutely pure seeds are not obtainabie in quantity for commerce and many samples that appear to be clean contain seeds of the most objectionable weeds. Clover seeds foul with Foxtail are often less harmful 
than apparently clean samples that contain a few seeds of Bladder Campion or Perennial Sow Thistle.

Commereial feeding stuffs usually find a better sale when not too finely ground. The records of analysis of a large number of samples of meals, manufactured principally from coarse grains of various kinds, show that vital seeds of noxious weeds are usually present. The ground sereenings from grain used for milling are a common ingredient of feeding stuffs. Many of the small weed seeds contained in them will retain their vitality until spread on the land with farmyard manure. Such small weed seeds should be separated from the coarser grains by screening, and burnt or finely ground apart from the grain.

\section{THE GRASS FAMILY (Gramineae).}

True grasses may be annual, biennial or perennial. They represent the most widely distributed plant family, which includes all our cereal grains and many valuable fodder plants as well as some of our worst weeds. The native grasses indicate to botanists the eharacter of the soil and climate of the locality where they are found, perhaps more than plants of any other family. Numerous species are persistent in farm crops, but only a comparatively few are characterized as noxious weeds.

Grasses are tufted or "bunched" when numerous stems rise from a single base or from short rootstocks, and ereeping when the rootstocks are long. Flowering stems and fibrous roots are developed from the joints or nodes at the base of the stem or along the rootstocks.

The stems of grasses are usually herbaceous and hollow, with thick, hard joints or nodes. In relatively few species the stem becomes woody, as in the bamboos, or filled with pith between the nodes, as in maize. The height varies from the tall bamboo to the dwarf mosslike species found within the Aretic Circle. 
The mode of flowering is by wide variation of spikes, as in Foxtail and Couch Grass, and also by panicles, according as the spike is more or less branched, as in Sweet Grass and Wild Oats. Both spikes and panicles are composed of spikelets, enclosed in scales or glumes, bearing one or more inconspicuous flowers.

The seed. What is commonly called a grass "seed" is composed of two distinct parts: 1. The kernel or caryopsis, which is really the seed as it contains the germ or young plant in a dormant state. 2. The scales or glumes, which are not an essential part of the seed but merely form a protective covering. Wheat, rye, hulless barley and corn, which belong to the Grass family, when threshed, are called true seeds, as the kernel or caryopsis is free from the glumes. The kernel or caryopsis of oats and the common grasses generally remains enclosed within the glumes. Occasionally both forms are found together as in timothy, which almost always contains both hulled and unhulled seeds.

The seeds of grasses are produced in abundance. They retain their vitality for a relatively short period. The various species have different contrivances for natural distribution. Those which give trouble as noxious weeds are distributed principally by human agencies. The seeds of all the weeds of the Grass family occur in commercial seeds of clovers, grasses, forage plants and cereal grains.

The annual and biennial grasses are propagated by seeds alone; the perennial species by seeds and rootstocks.

\section{OF GuLD.}

Gif thi malar (tenant) puttis guld (weeds) in thi land and will nocht deliuer it and clenge it he aw to be punyst puniri sicut seductor qui ducit exercitum in terra domini Regis vel baronis (hanged).

And gif thi natiff man or thi bonde (servant) haf fylit thi land with guld for ilk plant of it he sall gif to the or ony other lord a mutone (wether sheep) to be forfalt and neuer the les he sal clenge the land of the guld. 


\section{GREEN FOXTAIL (Setaria viridis (L.) Beauv.)}

Other English names: Pigeon Grass, Bottle Grass.

Other Latin names: Panicum viride L.; Chamaeraphis viridis Porter; Ixophorus viridis Nash; Chaetochloa viridis Scribn.

Introduced from Europe. Annual, tufted, stems erect, simple or branched from the base, leafy. The part of the leaf embracing the stem is smooth and hairless, while the margins of the extended portion are generally rough. Panicle thick, spikelike, its central axis bearing long soft hairs. Spikelet singleflowered, or with one perfect and one barren flower. From 1 to 3 persistent green bristles, upwardly barbed, inserted on the short footstalks just below the florets.

The seed (Plate 72, fig. 2) is generally found enclosed in a tough hard husk, 1/12 of an inch long, oval, with the outer scale rounded and folded over the polished rounded edges of the inner scale, which is flattened in the middle. Both scales of the husk are roughened crosswise with narrow ridges. The colour is very variable according to the degree of ripeness; yellow, gray, brown or purplish, the darker seeds mottled with darker spots. The kernel is greenish white, convex on the outer face, which bears the germ, and flattened on the inner face.

Time of flowering: June to September; seeds ripe by July.

Propagation: By seeds.

Occurrence: Abundant in eastern Canada; occasional in the West. The seeds are a common impurity in red clover seed.

Injury: A troublesome persistent weed in all crops on land not worked under a short crop rotation with clean cultivation. It seeds profusely from harvest to late autumn in cereal stubble lands, hoed crops, new meadows and clover seed crops. The presence of this seed as an impurity materially reduces the value of red elover seed for commerce.

Remedy: Thick seeding with clovers and grasses will help to suppress Foxtail in the autumh stubble and subsequent clover crop. In clover seed crops, the patches that have been winterkilled should be mown while the Foxtail is still quite green. 
The cut thus taken may be of value as fodder and the increased market value of the clover seed will more than repay the cost of the labour. Bare stubble should be plcwed shallow or disced to prevent the further ripening of seed directly after the grain crop is removed. Frequent and clean cultivation of hoed crops is needed to prevent Foxtail becoming established. The hoe should also be used to destroy late plants after cultivation of the crops becomes impracticable. Any practice that will prevent this annual from seeding will reduce and ultimately eradicate it.

ALLIED SPECIES: Yellow Foxtail (Setaria glauca (L.) Beauv.) Very similar to Green Foxtail. The branches, however, are more spreading, the whole plant is rather larger and more succulent, the spikes less compound and slenderer, with larger seeds. The bristles of the spike are distinctly yellow. The young plant has a broad pale-green leaf and the base of the stem shows a characteristic yellow colour.

The seeds are similar to those of Green Foxtail but larger. They are a common impurity in all kinds of grass and clover seeds, seed grain and feeding stuffs. Like most of the millets, they require a warm soil for growth, and the Foxtail plants are not much in evidence during the early spring months.

Closely allied to the Foxtails are the widely distributed Panic grasses (Panicum). While they are of various habits of growth, they differ essentially from the Foxtails by the absence of the persistent bristles below the florets.

The seeds of all of them have similar characteristics, such as the free grain enclosed in the horny scales, the margins of the outer one being more or less enrolled.

Most common in our crops is Old-witch Grass (Panicum capillare L.), a stout annual with hairy leaves and a large loosely spreading panicle about half the length of the whole plant.

The seed (Plate 72 , fig. 1) is about $1 / 16$ of an inch long, spindle-shaped in outline, highly shiny, olive green, with white parallel nerves, more yellowish when unripe. It occurs often and in large quantities in the seeds of timothy and other grasses. 
SWEET GRASS (Hierochloë odorata (L.) Wahlenb.)

Other English names: Indian Hay, Vanilla Grass, Seneca Grass, Holy Grass, incorrectly called Couch or Quack Grass.

Other Latin names: Holcus odoratus L.; Hierochloa borealis Roem. and Schultes; Savastana odorata (L.) Scribn.

A native grass, sweetly aromatic, with the fragrant principle of the Tonka Bean and Sweet Clover (Coumarin).

Perennial, deep-rooted, with wide-spreading white rootstocks, which produce in summer many barren shoots with long, flat, shining leaves of a deep green, over a foot in length. Flowering stems are thrown up early in spring, the first flowers opening when the stems are only a few inches out of the ground. Panicle pyramidal, 1 to 3 inches high, loose during flowering, with spreading branches, contracting and becoming dark golden-brown as the seeds ripen, when the stems are 12 to 18 inches high. Spikelets drooping, with shining papery outer scales, which are yellowish tinged with purple, 1-seeded but 3-flowered, two male flowers between scales, the margins of which are fringed with hairs, and one female flower in the centre inside two smooth scales.

The seed (Plate 72, fig. 3) is enclosed in the inner smooth scales. The naked seed closely resembles timothy, but is thinner, more cylindrical, and sometimes bears at its apex the remainder of the dried-off style (the elongated part of the pistil). The miniature root of the germ is more prominent.

Time of flowering: April to May; seed ripe by the beginning of June.

Propagation: By seeds and running rootstocks.

Occurrence: Rare in the eastern provinces, growing mostly in damp places by streams and rivers. Under-ripe stems of this grass are gathered, cured and sometimes stained by Indian women for weaving baskets, mats and other ornaments. In 


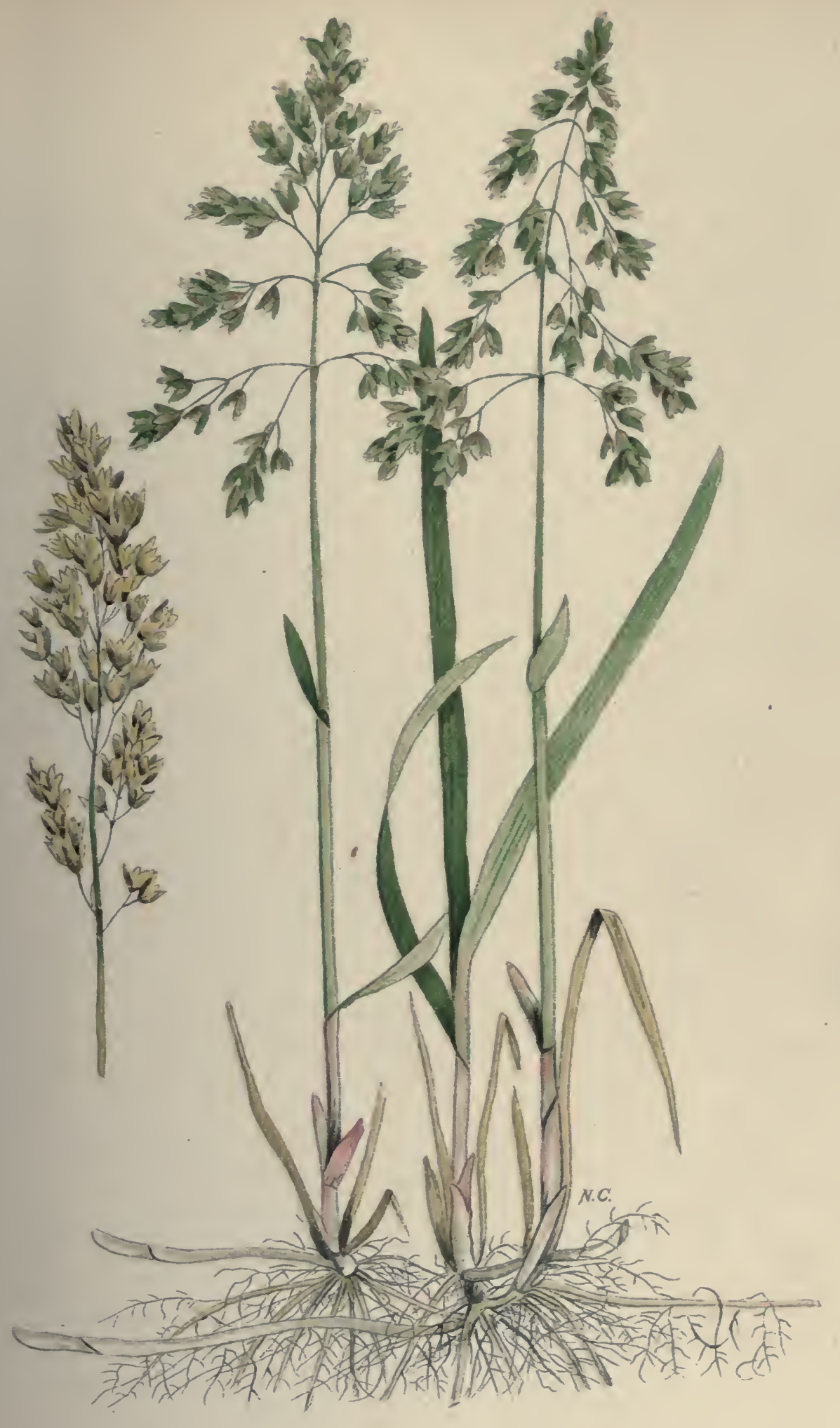

Plate 2

SWEET GRASS OR HOLY GRASS

(Hierochloe odorara(L) Hahlemb) 

Manitoba, Saskatchewan and Alberta it is widely distributed and seems to thrive on all kinds of soil.

Injury: Where it has become firmly established it crowds out any cultivated crop. It is a rapid grower and on the prairie quickly spreads over cultivated lands. On account of its deep and persistent rootstocks, it is a difficult weed to suppress.

Remedy: Mow and burn while the grass is in bloom in May, to destroy the seeds. Then plow deeply to get below the rootstocks, which may be brought to the surface by thorough cultivation, continued through the summer. This will be made more effective by deep plowing as late in the fall as the frost will allow.

Good results have been obtained in Manitoba by plowing deeply in spring when the Sweet Grass is in flower and at once seeding down heavily to barley.

For Saskatchewan, Angus MacKay recommends as follows:"The first plowing should be done when the ground is dry and the weather hot; early in August gives the best results. Plow deep and leave the ground rough for a few days, then harrow and repeat the plowing in another week if the weather is warm and dry. Plowing when the ground is wet only spreads the weed."

The Diseases and ill Accidents of Corn, are worthy to be enquired, and would be more worthy to be enquired, if it were in men's power to help them; whereas many of them are not to be remedied. The Mildew is one of the greatest, which (out of question) cometh by closeness of Air; and therefore in Hills, or large Champain-Grounds, it seldom cometh.... This cannot be remedied, otherwise than that in Conntreys of small enclosure the Grounds be turned into larger Fields: Which I have known to do good in some Farms. Another Disease is the putting forth of Wild Oats, whereinto Corn oftentimes (especially Barley) doth degenerate. It hapneth chiefly from the weakness of the Grain that is sown; for if it be either too old or mouldy, it will bring forth vild Oats...... Another Disease is Weeds; and they are such, as either choak and over-shadow the Corn, and bear it down, or starve the Corn, and deceive it of nourishment. 


\section{WILD OATS (Avena fatua L.)}

Other Latin names: Avena fatua L., var. glabrata Petermann; Avena fatua L., var. glabrescens Cosson.

Introduced from Europe. Annual, smooth, 2 to 4 feet high, growing in erect tufts. Plant closely resembles some varieties of cultivated oats. Panicle is compact when it appears but quickly opens, spreading in all directions, 6 to 12 inches long.

The seeds (Plate 72, fig. 4) vary greatly in size and in colour; they are brown or gray of different shades, sometimes yellowishwhite. They are similar to those of the common cultivated varieties of oats, but generally slimmer, harder, of a horny appearance, and show the following characteristics of differentiation:-

1. The strong, twisted, right-angled awn, frequently broken off by threshing.

2. The stiff bristles surrounding the basal scar, which, however, are not always present in threshed grain.

3. The slanting horseshoe-shaped scar at the base of the seed, which is sometimes broken off by the thresher or other machine.

4. The minute stalk (rachilla) which bears the second or "bosom" grain, but which remains attached to the lower grain, is larger and thicker. The free end is slanting, roughly triangular and shows a marked depression.

5. The abundance and roughness of the hairs covering the kernel.

Time of flowering: Uneven, commencing about the last of June; some seeds ripe by the middle of July.

Propagation: By seeds only. Plants cut off when in flower throw up secondary flowering stems very quickly.

Occurrence: Widely distributed throughout Canada; most abundant and troublesome where cereal crops predominate. 


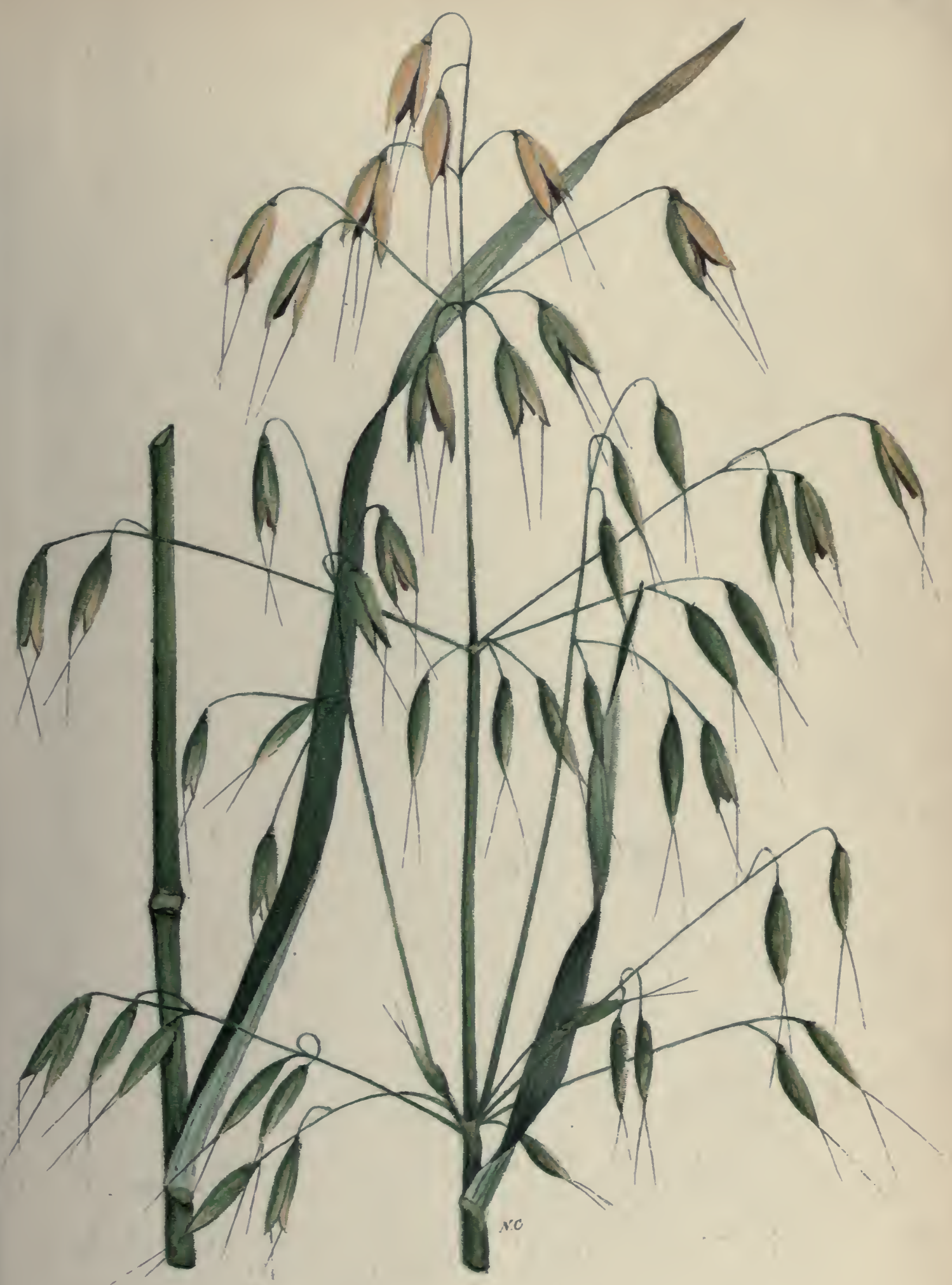

Plate 3

WILD OATS .

(Avena farua L) 

Injury: Wild Oats are hardier and more vigorous than cultivated varieties of cereals. Unlike those of the latter, the Wild Oat seeds retain their vitality for several ycars, though probably not longer than seven years even in the dry soils of the western plains. The seeds on the upper part of the head and on the tips of the branches ripen earlier than those less exposed. The earlier seeds are dropped before or during harvest; thus Wild Oats tend to increase on lands where the production of cereal grains predominates. The later maturing seeds are harvested with the crop and remain in commercial wheat, oats and barley. They are the most prevalent impurity in westerngrown grain and the annual loss entailed thereby is enormous.

Remedy: Sow clean seed grain. In the eastern provinces lands polluted with Wild Oats may be seeded to grass for hay or pasture for five years. Surface cultivation after harvest will start germination of the seeds scattered during harvest. Any method of cultivation or arrangement of crops that will induce the seeds in the soil to germinate and permit the destruction of the plants before they have produced seed will eventually exterminate Wild Oats. A short crop rotation, with clean cultivation of the hoed crop and seeding to clover or grasses, with a soiling or other crop in which Wild Oats can not mature and drop their seeds, will do much to clean the land of this pest.

To eradicate Wild Oats in the Prairie Provinces, the land should be plowed shallow or disced immediately after an infested crop is harvested; the best method is to have the disc follow behind the binder. The purpose of this is to cover the seeds of Wild Oats. Some of them will germinate in the autumn; the remainder will start in the spring. As soon as they appear in the spring, the ground should be plowed shallow to destroy them and to start another growth. This should be followed in about two weeks by deep plowing, to bring up the seeds lying at a greater depth. Harrow after each plowing, to start growth. During the remainder of the summer Wild Oats should be kept down by the use of the disc or broad-shared cultivator. The 
next season, stray plants should be hand-pulled; or, if they are still thick in a few spots, they should be cut and burnt. \& to

Instead of continuing the summer-fallow, sow in June, after the second plowing, a crop for green feed. This crop, however, must be cut before any of the Wild Oat seeds approach maturity. Sometimes early barley is sown in the hope of ripening grain, but this is risky. Cattle and sheep may be pastured on infested land with good results. Their tramping packs the soil and stimulates germination, and they eat off the young plants.

Seed is often allowed to ripen on the edges of fields and in fence corners, and thus the object of much faithful work is defeated.

\section{CHESS (Bromus secalinus L.)}

Other English names: Cheat, Wheat Thief.

Introduced from Europe. Winter annual, stems erect, simple. The portion of the leaf that embraces the stem is smooth, strongly nerved. Panicle loose, its branches somewhat drooping, with many flowered, hairless spikelets, which are so distinct as to show openings between them along the stalk, when viewed from the side.

The seed (Plate 72, fig. 5) is about $1 / 3$ inchlong, enclosed in scales of the same length. The outer one is convex, thick and, unrolled at the margin when ripe, provided with a short bristly awn. The inner scale is bordered with stiff hairs and adherent to the kernel. The footstalk of the grain above is strongly curved and club-shaped.

Time of flowering: June, seeds ripen in July.

Propagation: By seeds.

Occurrence: Widely distributed wherever winter wheat or other fall or winter crops are grown. 


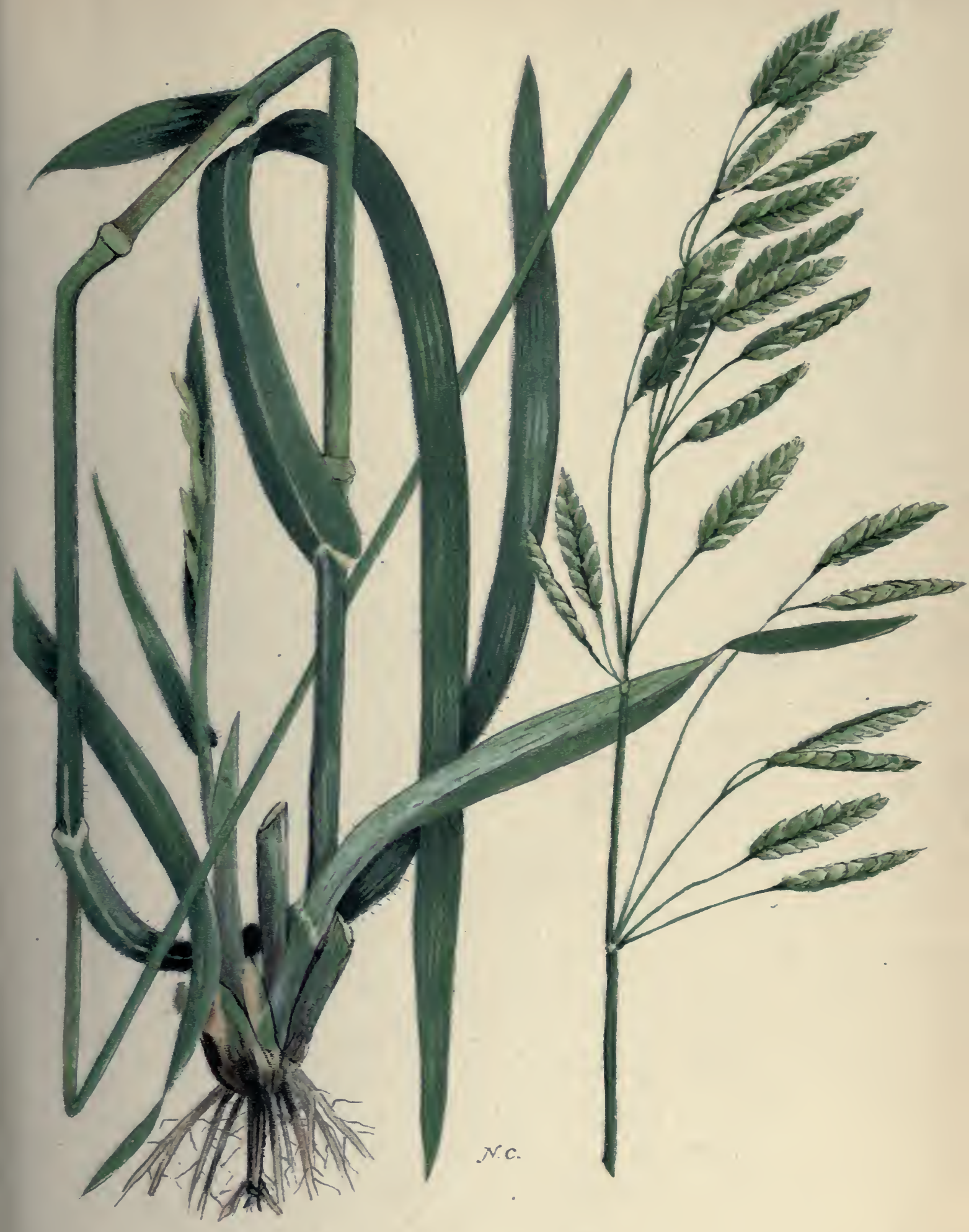

Plate 4

CHESS OR CHEAT

(Bromus secalinus 1 ) 
$\therefore$

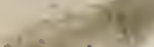

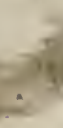


Injury: Chess is hardier than wheat, and where the young winter wheat has been killed out the Chess is seldom injured. Being a vigorous grower, it stools freely and becomes much in evidence where the wheat has been partially destroyed. This appearance of Chess, apparently only in those patches where the wheat has been winter-killed, has led some farmers to the erroneous conclusion that Chess is a degenerate form of wheat. It is a common impurity in winter wheat, and, to a less extent, in winter rye and other grains and seeds of commerce, and in feeding stuffs. Chess is objectionable in wheat for milling as it gives the flour a dark colour and a disagreeable fla vour. Removing it by cleaning causes considerable loss of the smaller grains of wheat.

Remedy: Use clean seed. The seed of Chess is short-lived. When buried in the soil it will not retain its vitality for more than three or four years. A four years rotation of crops, exclusive of winter grains, will clean the soil of its seeds. Cut and destroy all patches of Chess where the grain crop has killed out. Do not allow the seeds to become mixed with manure and be transported again to the fields. Farm stock or birds, when given an opportunity to feed on mature Chess or its seeds, will do much to distribute vital seeds. For a field badly infested, thick seeding with early red clover is recommended. The first crop of hay should be cut before Chess has had an opportunity to produce seeds.

ALLIED SPECIES: Soft Chess (Bromus hordeaceus L.) is occasionally found in fields and waste places in the eastern provinces. It is shorter, and the whole plant is of a soft hairy character. It seldom gives trouble as a weed.

Slender Chess (Bromus tectorum L.) is another species sometimes met in waste places, rarely in fields. It is characterized by slender stems, soft hairy leaves and long awns. 


\section{COMMON DARNEL (Lolium temulentum L.)}

Other English names: Poison Darnel, White Darnel, Ivray, Poison Rye Grass, Bearded Darnel.

Other Latin name: Lolium arvense With.

Introduced from Europe. Annual, smooth, stems 2 to 4 feet high, simple. Leaves smooth beneath, rough above, the portion embracing the stem is purple when the plant is young. Spike 6 to 10 inches long; somewhat resembling that of Couch Grass, but having the edges of the spikelets resting against the stalk instead of the broadsides, as in Couch Grass. Spikelets 3 to 7-flowered, solitary, stalkless and alternate, with their edges fitting tightly into grooves on either side of the stalk; each spikelet in the axil of a long, rigid, strongly-nerved, persistent empty scale, which nearly equals or is sometimes much longer than the spikelets.

The seed, somewhat swollen, resembles small barley, with blunt ends and a shallow wide groove on the inner surface. The inner scale is minutely bristly on the edges but not coarsely bristly along the margins, as in Chess; the outer scale is hard and flinty, as in the chaff of wheat, and either with or without a long awn. The footstalk of the grain above on the spikelet is long, flat, smooth, straight-cut on the top. The kernel, after the husks have been removed, is greenish-brown, often tinged with deep purple. Darnel seeds are found in western wheat.

Time of flowering: July; seeds ripe in August.

Propagation: By seeds.

Occurrence: Abundant in parts of the Red River Valley, Manitoba, and occasional throughout the Prairie Provinces. Most common in moist land.

Injury: The scales cover the seed very tightly, the inner one being adherent to it; in that condition it is nearly the same size and weight as small grains of wheat and is exceedingly difficult to separate by machinery. Darnel has become a 


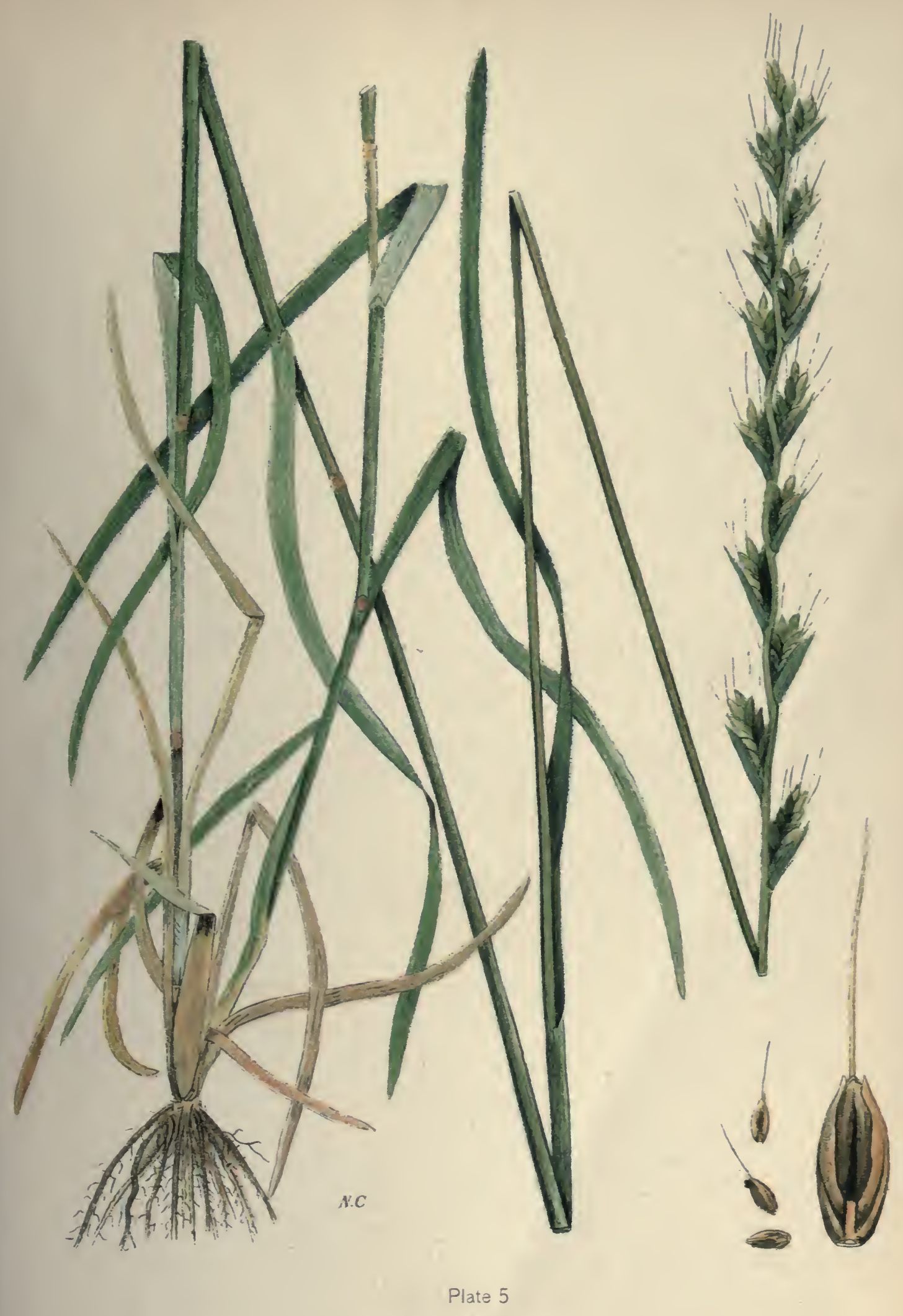

COMMON DARNEL

(Lolium temulentum $L$ ) 

serious pest in wheat fields in some localities where it has been recently introduced. The market value of wheat is materially reduced by the presence of Darnel seeds in quantity.

The seeds of Darnel are reputed to be poisonous. In "The True Grasses," by Edward Hackel (translated), is the following :-

"The grain contains a narcotic principle (Loliin), soluble in ether, which causes eruptions, trembling and confusion of sight in man and flesh-eating animals, and very strongly in rabbits; but it does not affect swine, horned cattle or ducks."

Dr. E. M. Freeman, of the University of Minnesota, has shown, however, that there are two races of the plant, one with a fungus and another without, and that there is apparently no transference of the fungus from one race to the other. In referring to the results of his investigations, he says: "If the seeds are really poisonous, it may be that those with the fungus are poisonous, while those without fungus are not. I have attempted recently to determine this, but have failed to get any conclusive results."

Remedy: Sow clean seed. It is not definitely known how long the seeds will retain their vitality. Lands badly infested with Darnel may be seeded to grass to advantage. That will prevent it from spreading in seed grain and will ultimately destroy the vitality of the seeds in the soil. Feed grain containing Darnel should be finely ground. It is distributed principally in seed grain, feeding stuffs and by other human agencies. The method of eradication outlined for Wild Oats will be effective for Darnel. 


\section{COUCH or QUACK GRASS (Agropyron repens (L.) Beauv.)}

Other English names: Scutch, Twitch, Quitch Grass. Other Latin name: Triticum repens L.

Introduced from Europe. Perennial, by wide-spreading but shallow fleshy rootstocks, forming large matted beds. Flowering stems rather freely produced, smooth above, downy below. Flowers in 3 to 7 -flowered spikelets, forming a narrow spike with the spikelets lying flat against the stalk. Leaves dark green, rather distinctly ribbed, and more or less hairy below.

The seeds in the scales (Plate 72 , fig. 6 ) are about $3 / 8$ of an inch long. The kernel is shaped like a small grain of wheat $3 / 16$ of an inch long, with wide-open groove. The basal end which bears the germ is pointed, while the other end is blunt and fuzzy The seeds are a common impurity in seeds of the coarser grasses, and in litter from hay or straw containing mature Couch Grass.

Time of flowering: About the end of June; seeds ripe in July.

Propagation: By seeds and creeping rootstocks near the surface of the ground. When the rootstocks are broken by plow or cultivator, each segment is capable of forming a new plant; these pieces may be carried from field to field on farm implements.

Occurrence: Widely distributed throughout Canada and a most injurious weed in all kinds of soil. Abundant east of the Prairie Provinces and also in a few localities in the West.

Injury: A most persistent weed in all deep-plowed lands and in all crops, with great power of spreading and choking out other plants.

Remedy: Let the plant exhaust its substance in the production of a hay crop, which should be cut and removed as soon as the head is formed and before it is in bloom. Plow shallow and cultivate until the rootstocks have been brought to the surface by implements that can be forced, after repeated appli- 


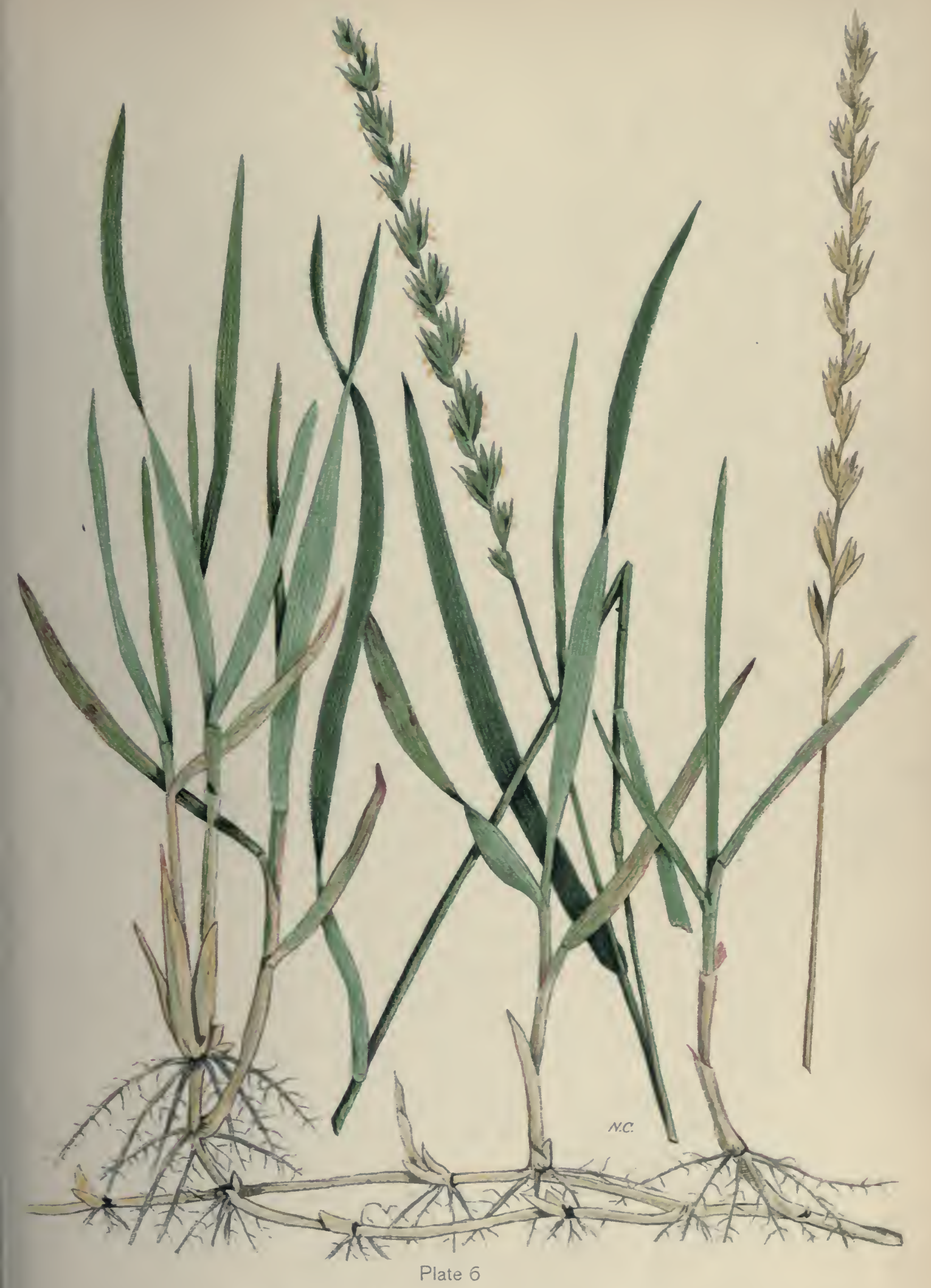

COUCH, QUACK OR SCUTCH GRASS

(Agropyron repens (Imsam.) 

cations, to the full depth of the furrow. A disc is not satisfactory because the cuttings from the rootstocks are difficult to gather and they perpetuate the growth, wherever transplanted. When brought to the surface the rootstocks should be gathered and burnt or removed. This should be done at once before the plant has had an opportunity to renew its growth. For Manitoba, S. A. Bedford recommends plowing up the Couch Grass late in the spring and seeding at once to barley, three bushels to the acre.

Rape, buckwheat or millet, sown after the land has been well cultivated and the rootstocks removed, is a good cleaning crop for late sowing. The land may be put under hoed crop, corn, potatoes or roots the following year.

\section{ALLIED SPECIES: Blue Joint or Western Couch Grass} (Agropyrum glaucum R. \& S. var. occidentale V. \& S.) is a native of the western prairies, where it is hardy and persistent and prevalent everywhere. It is differentiated from the common Couch Grass by the decided grayish-green colour of its foliage. It is often troublesome when breaking is done carelessly, but continued thorough cultivation of the land will exterminate it in a few years. It gives trouble on the prairies among trees and shrubbery and should be thoroughly subdued before such plantations are laid out.

\footnotetext{
Slack neuer thy weeding, for dearth nor for cheap, the corne shall reward it, yer euer ye reape: And speciallie where, ye do trust for to feed, let that be well used, the better to speed.
}

-Thomas Tusser, Five Hundreth Pointes of Husbandrie, 1557.

There is an opinion in the Countrey, That if the same Ground be oft sown with the Grain that grew upon il, it will, in the end, grow to be of a baser kind. It is certain, that in very Sterile Years, Corn sown will grow to an other kind. And generally it is a Rule, that Plants that are brought forth by Culture, as Corn, will sooner change into other Species, than those that come of themselves: For that Culture giveth but an adventitious Nature, which is more easily put off. 


\section{SKUNK-TAIL GRASS (Hordeum jubatum L.)}

Other English names: Skunk Grass, Squirrel-tail Grass, Wild Barley, Tickle Grass, and, inaccurately called Foxtail.

Native. Perennial, not flowering the first year, forming tufts 8 to 12 inches high. Leaves grayish-green. Flowers in beautiful, silky, bristly heads, 3 to 4 inches long, pale yellowishgreen often tinged with red. When ripe, the spikes break up into 7-awned clusters of three flowers. The central long-awned flower is the fertile female one; on each side of it and attached to its base are two barren flowers, each with three shorter awns.

The seed produced by the female flower is slender, sharp pointed, somewhat resembling a miniature seed of barley, and provided with a long, upwardly-barbed awn.

Time of flowering: July; seeds ripe July to August.

Propagation: By seeds. This grass is frequently said to be an annual or biennial; but all the plants grown in Ottawa from western seed during the past twenty years are certainly perennial, forming large tufts but sending out no running rootstocks.

Occurrence: From Lake Superior westward, particularly in alkaline soil where better grasses can not thrive. Occasional in eastern Canada.

Injury: This grass is a serious enemy to western stockmen, being a source of much injury to horses, cattle and sheep. The barbed seeds and awns penetrate the soft tissues of the mouth, causing irritation and inflamed ulcers; they work down beside the teeth, producing inflammation and swelling; and they are also said to work into the wool about the eyes of sheep, then into the tissues surrounding the eye, and even into the ball itself, in many instances causing total blinchess.

Remedy: T. N. Willing, of Regina, Sask, sums up the best methods of dealing with Skunk-tail Grass as follows:- 


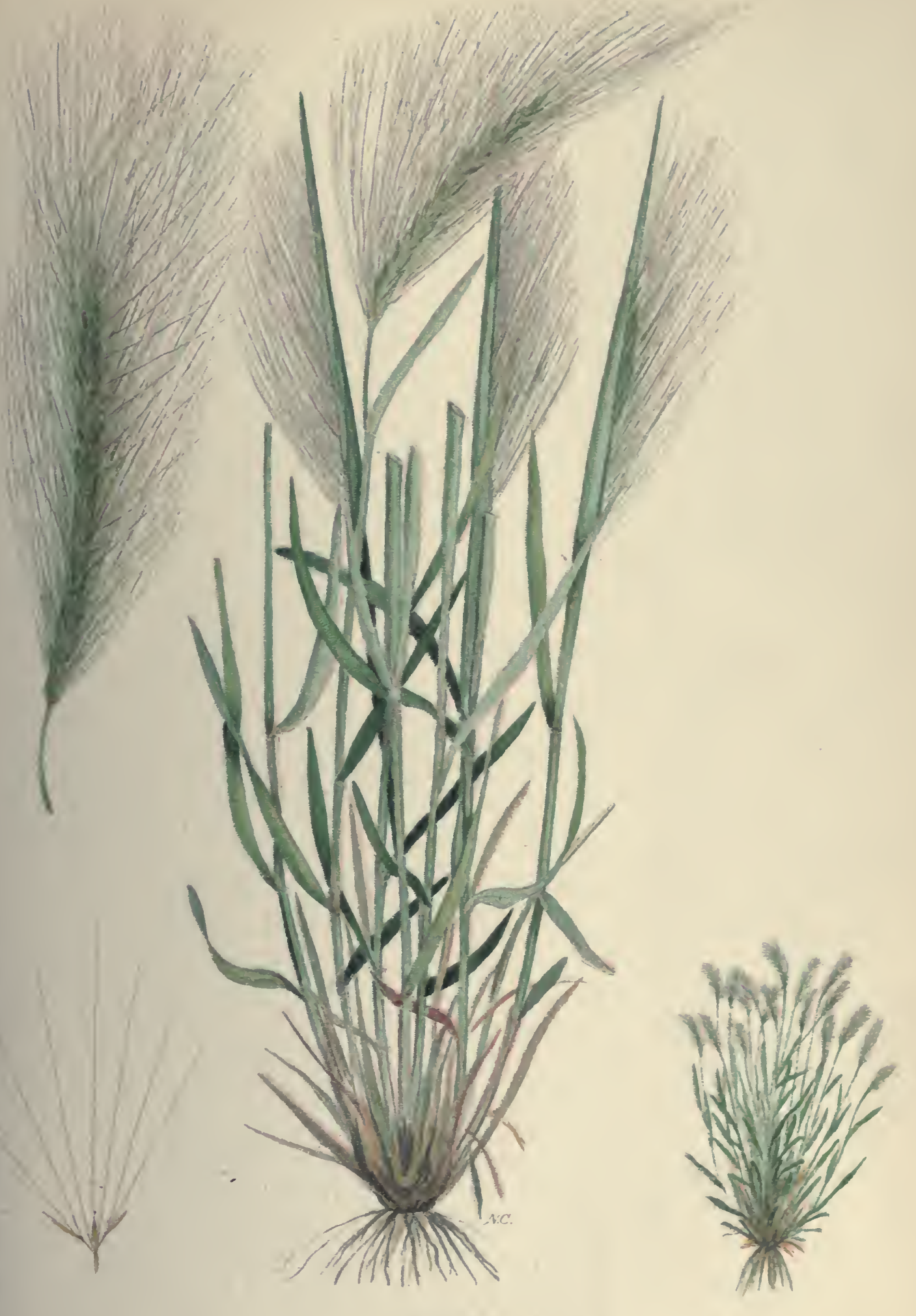

Plate 7

SKUNK GRASS. WILD BARLEY OR SQUIRREL-TAIL GRASS

(Hordeum jubarum $L$ ) 

"There is no difficulty in eradicating this grass from any land which can be plowed, as the usual method of breaking in June will destroy it. It gives most trouble in waste places where it ripens its seed, which is spread abroad in every direction by wind and water. It grows freely about the edges of hay sloughs on the prairie and is generally ripe before any hay is cut. The remedy in this case would be cutting before the seeds were formed. In a wet season probably a second cutting would be necessary to prevent any seed ripening. When fields of awnless brome grass are badly infested, it is best to break and backset and then take a crop of grain before re-seeding; or the fields may be burnt over in the fall to destroy such seeds of the Wild Barley as may have fallen; early in the following spring plow the sod shallow and then harrow and roll. In this way the brome grass may be renewed without re-seeding, and most of the weed will have been destroyed."

The face of Nature smiles serenely gay;

And even the motley race of weeds enhance

Her rural charms: Yet let them not be spared;

Still as they rise, unconquered, let the hoe

Or ploughshare crush them. In your fields permit

No wild-flower to expand its teeming bloom:!ri? In wood and wild, there let them bud and blow By haunted streamlet, where the wandering bee, Humming from cup to bell, collects their sweets.

-James Grahame, British Georgics, 1812.

When the farmer has been at the Charge of enriching and tilling his Ground, he expects the advantages of his labours and Expence; and wishes the improvements he has made in the land may give all its Fertility to his Crop; but he is to consider Nature sows while he is sowing; her provision for keeping up the Species of Plants is very wonderful; their Seeds are Scattered to great Distances, and where they fall they grow. While the Seeds of some Plants are winged with Down to make them float upon the Air, the roots of others are so full of life, that the least Morsel of them remaining in the Ground will grow. Tis not with Plants as with Animals: in these the loss of a limb or other essential Part cannot be restored, except in some few particular Kinds: but in Plants, while anything remains the whole will be renewed. Hence is the origin of Weeds to be trac'd by the Farmer, and hence he will find them universal. 


\section{ERGOT on COUCH, RYE and TIMOTHY}

(Claviceps purpurea (Fr.) Tul.)

There are often found among grains of rye, rarely among those of wheat, and abundantly among the seeds of some grasses, blackish or purplish solid bodies, commonly called ergot. Fresh specimens are of a waxy or oily consistency, purplish white inside. They are the storage organs or resting stage of a parasitic fungus belonging to the genus Claviceps. Ergot grains vary in size and form, according to the species of grain or other grasses on which they develop. Each of these solid bodies is called a sclerotium (plural sclerotia), derived from a Greek word skleros, hard or dry, in allusion to their nature. They are a part of the vegetative system, the "spawn" of the fungus, in a resting condition, but capable of growth in the spring under such favourable conditions of warmth and moisture as they get when sown with crop seed, or when lying on the ground at the bases of the stems on which they were formed the previous summer. In the spring small toadstool-like bodies, on violet stalks, with round, orange-coloured heads, about the size of mustard seed, are produced from the sclerotia lying on the ground. These develop enormous numbers of microscopically small spores (organs analogous to the seeds of higher plants), at the time when grasses and grains are in flower. The minute spores, carried by currents of air or by insects, lodge in the flowers of the grasses and grow; in a short time they completely destroy the seed and form from them the horn-like sclerotia. During the summer spores are formed on these horns; at the same time appears a sugary secretion, very attractive to insects, which carry off on their bodies many of the summer spores to the flowering heads of other grasses and thus spread the infection. Late in the summer the production of spores stops, and the sclerotia or storage organs begin to lay up a kind of starch found only in fungi and known as fungus starch, as well as oils, to serve as food for the growth 


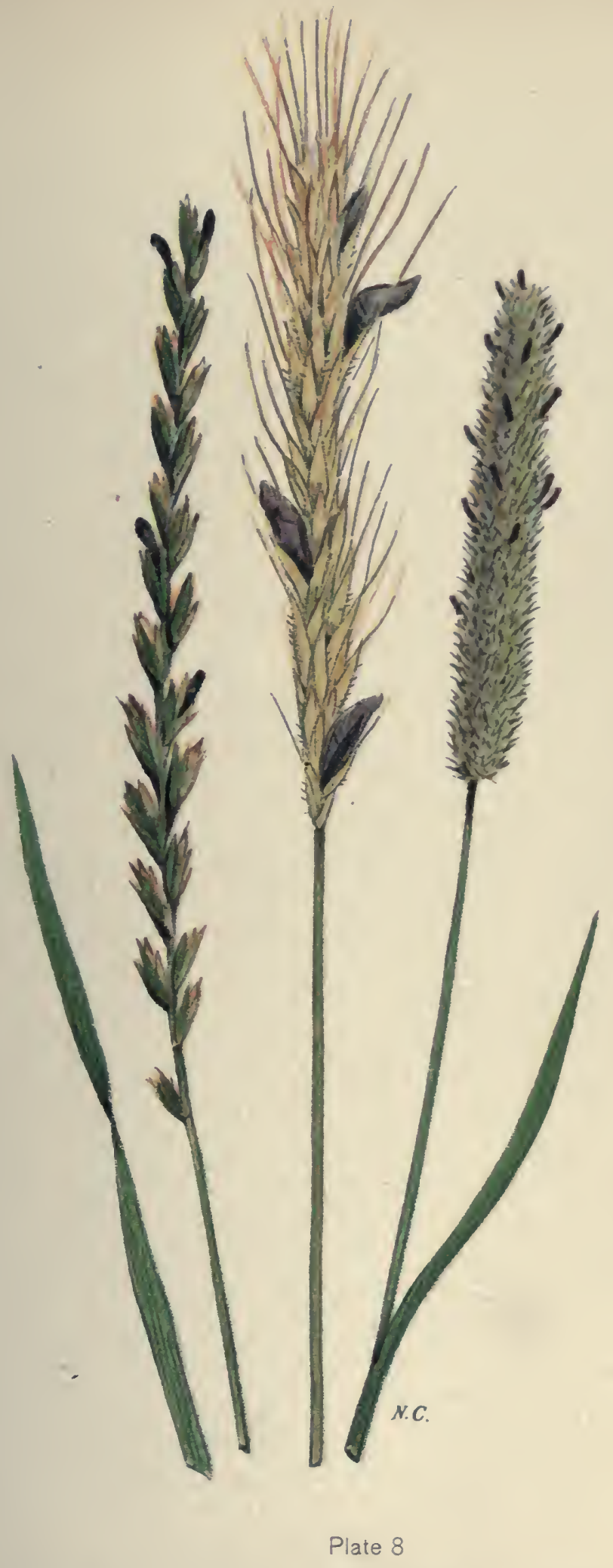

COUCH OR QUACK GRASS, RYE AND TIMOTHY attacked by Ergor 

of the fruiting organs to be sent out the following spring. They then harden up, turn dark purple, and fall to the ground or are carried away with the grain or hay.

The sclerotia are common on many grasses, particularly on rye, wheat, barley and wild rice, as well as on Western Couch Grass and other prairie grasses cut for hay. They all contain an alkaloid and other violent poisons. Some are used in medicine under the name of "Ergot of Rye." Bread made from flour containing ergot may cause a serious disease known as ergotism; and animals which feed on grain or hay containing ergot may also be severely poisoned, as is sometimes the case on our western plains. Abortion is one well known result of cows feeding on ergotized grain.

Hay containing much ergot should not be fed. Ergotized grain should be thoroughly screened and the sclerotia destroyed. Seed from an ergotized crop should not be used if any other can be procured.

\section{THE SEDGE FAMILY (Cyperaceae).}

The sedges are similar to the grasses in general appearance, with fibrous roots and mostly solid stems. The part of the leaf embracing the stem is closed. Galingale (Cyperus diandrus Torr.), Nutgrass (Cyperus esculentus L.) and other species are troublesome weeds, particularly in hoed crops on wet lands. Nutgrasses spread by short rootstocks and are exceedingly difficult to eradicate. Land where sedges give trouble should be thoroughly drained; they will then succumb to autumn fallow with clean cultivation followed by hoed crop. Some of the sedges as Awned Sedge (Carex trichocarpa Muhl. var. aristata (R. Br.) Bailey) and a few of the allied species, are valuable fodder plants for wet lands.

In general those Weeds are most numerous which rise from Seeds; and those most, difficult to be extirpated which come from Roots. 


\section{THE RUSH FAMILY (Juncaceae).}

Like the sedges, the members of the Rush family are common in wet lands and bogs. The so-called Poverty-grass or Slender Rush (Juncus tenuis Willd.), which is perennial, sometimes gives trouble in low places in fields and pastures. The rushes are of practically no value as forage plants. Wherever found, they indicate the need of drainage. In pastures that can not be thoroughly drained, repeated cutting of the rushes and thick seeding with true grasses that thrive in wet soils is recommended.

\section{THE BUCKWHEAT FAMILY (Polygonaceae).}

This family contains several weeds besides a few cultivated plants, such as buckwheat, India-wheat, rhubarb, and a number of ornamental varieties. They are distributed all over the continent in all kinds of soil, though they generally thrive best in low, damp locations.

Their habit of growth varies, but they are nearly all herbaceous plants, with hollow stems swollen at the joints. The leaves are alternate, without any teeth or divisions but with appendages at the base of the footstalk, embracing the stem. The flowers are small, grouped together in spikes or drooping clusters, nearly always supported by jointed stalks, the calyx and the corolla often wanting or not showy.

The seeds are small, generally compressed, angled or lensshaped or winged. They are widely distributed with the seeds of commerce, as they are in many cases of the same shape or size.

The troublesome weeds of this family belong to two genera, the Docks (Rumex) and the Smartweeds or Knotweeds (Polygonum).

Docks are tall-stemmed weeds with tap-roots, perennial, but not spreading from the root except in a few cases, as 
Sheep Sorrel. The seeds are shaped like those of the buckwheat, being triangular in cross section; or, as the name buckwheat (which is merely a corruption of beechwheat) indicates, shaped like small beechnuts. There is no true corolla, the seeds being surrounded merely by the six-parted calyx, three divisions of which are small and the other three large, winglike and variously shaped and veined in the different species. One or all three of these wings may bear a seedlike, corky tubercle on the outside. The seeds of all species are much alike, and the winglike calyx divisions, often found attached to the seeds, are a great help in identifying the different species.

While a certain number of the Docks are native, all the worst varieties have been imported with foreign clover seeds; several are already agricultural pests.

Smartweeds and Knotweeds have various habits of growth, being, with few exceptions, herbaceous plants with fibrous roots, annual or perennial, terrestrial or aquatic, erect or prostrate, climbing or floating. Of the many different groups which can be easily distinguished, three are important as including weeds:-

1. The group "Avicularia": mostly prostrate, smooth annuals with small linear oblong leaves, represented by Doorweed (Polygonum aviculare I.).

2. The group "Persicaria": generally tall, annual, erect, branching plants, with larger lance-shaped leaves, represented by Lady's Thumb (Polygonum Persicaria L.).

3. The group "Tiniaria": twining annuals and perennials, with heart-shaped leaves, typically represented by Black Bindweed (Polygonum Convolvulus L.).

The seeds are lens-shaped or triangular, with blunt edges, generally dark-colored, shiny and have the general characteristics of the family, but the divisions of the enlarged fruiting calyx in which they are enclosed are not winglike as in the Docks. They ripen late and are commonly found in clover and grass seeds. 


\section{CURLED DOCK (Rumex crispus L.).}

\section{Other English names: Yellow Dock, Sour Dock.}

Introduced from Europe. Perennial, with a deep tap-root. Stem 2 to 3 feet, smooth, erect, terminating in wandlike racemes. Root-leaves oblong-lance-shaped in outline with much crested or waved margins, 6 to 12 inches long, on long stalks; stem-leaves on short stalks and much smaller or absent towards the top of the stems. Flowers small, in rather widely separated clusters around the stems. Flower stalks with swollen joints. The 3 inner divisions of the calyx enlarging as the seed ripens, heart-shaped, with the margin only obscurely or not toothed, all with seed-like tubercles on the outside.

The seeds (Plate 72, fig. 7) are $1 / 12$ of an inch long, shaped like a miniature beechnut, reddish brown, shining. They are one of the commonest impurities in clover seeds. European grown clover contains seeds of allied species.

Time of flowering: June; seeds ripe by July.

Propagation: By seeds. The clumps increase slowly by shoots from the crown of the root of old plants.

Occurrence: In fields and waste places. Naturalized from Atlantic to Pacific, very abundant in southern and western Ontario.

Injury: A common weed in meadows, pastures and waste places. It is a pest in new meadows and depreciates the value of the fodder or the clover seed crop. The Docks harbour plant lice. When young and tender the leaves are sometimes used for pot herbs.

Remedy: Sow clean seed. The prevalence of Dock in meadows is due to sowing contaminated grass and clover seeds. Land worked under a short rotation of crops is never badly infested with Docks. When the soil is soft after continued rain, they can be pulled from meadows and pastures. Pull or cut and destroy all seed-bearing plants before harvesting a clover 
seed crop. A handful of salt placed on the crown of Docks, after cutting in dry hot weather, will extract the moisture and destroy the root; this is a remedy sometimes used in lawns and pastures when the soil is too hard and dry to permit pulling them.

ALLIED SPECIES : Veined Dock (Rumex venosus Pursh.) is a perennial which differs from Curled Dock in having running rootstocks and a larger, smoother leaf with prominent veins; the flowers, in short panicles, are larger than those of Curled Dock, pink in colour, and, unlike most of the species of the genus, quite attractive in appearance. It is native to western Canada and gives trouble in some of the lighter soils of southern Alberta and Saskatchewan. The seed is nearly $1 / 4$ of an inch long. The most satisfactory remedy is deep plowing when the plant is coming into bloom.

The seeds of the Docks commonly found in imported clover seeds are strikingly alike, but have the following points of differentiation.

Curled Dock (Rumex crispus L.). Seeds nearly symmetrical, both ends pointed, widest near the centre, the edges very slightly margined, reddish brown and highly shiny.

Clustered Dock (Rumex conglomeratus Murr.). Apex of the seed pointed, base rounded, smaller, plumper, dark reddish brown. The plant is characterized by its oblong, smoothish leaves and its leafy panicle of flowers on short stalks.

Bitter Dock (Rumex obtusifolius L.) Seed unsymmetrical, widest below the centre, edges unmargined, the base with a rough scar, brownish yellow, dull. The lower leaves of the plant are broad and heart-shaped and the stem somewhat roughened.

The seeds of most sorts of weeds are so hardy, as to lie sound and uncorrupt for many years, or perhaps ages, in the earth; and are not killed until they begin to grow or sprout, which very few of them do unless the land be ploughed, and then enough of them will ripen amongst thé sown crop to propagate and continue their species, by shedding their offspring in the ground (for it is observed they are generally ripe before the corn) and the seeds of these do the same in the next sown crop; and thus perpetuate their savage, wicked brood, from generation to generation. 


\section{SHEEP SORREL (Rumex Acetosella L.)}

Other English names: Sour-grass, Field Sorrel, Red Sorrel.

Introduced from Europe. Perennial, very persistent by extensively spreading, yellow, fleshy rootstocks. Stems slender, 6 to 18 inches, erect or nearly so, branched above. Leaves with silvery ear-like appendages, spreading outward from the base, narrowly arrow-head-shaped, toothless, 1 to 4 inches long, quite smooth and rather fleshy, on long stalks. Flowers numerous in panicle-like racemes, of two kinds on separate plants; the male flowers have conspicuous stamens; the female are much less showy and are tipped with three tiny, crimson, feather-like organs (the stigmas).

The seeds (Plate 72 , fig. 8), as they occur among clover and grass seeds, are generally covered by the three larger conspicuously veined calyx divisions which fit closely over the seed. The three small divisions, which alternate with these, fit over the angles of the seed outside the edges of the larger divisions. The naked seed when the calyx divisions are removed, is $1 / 20$ of an inch long and nearly as broad, triangular-ovate, pale brown, shining.

Time of flowering: May to August; seeds ripe July to September.

Propagation: By seeds and shallow running rootstocks.

Occurrence: Naturalized in all parts of the country.

Injury: The seeds are one of the most abundant impurities in clover and grass seeds. The plants increase rapidly in thin or worn-out meadows and pastures, both in uplands and in hay marshes, crowding out the grass and greatly reducing the crop. Sheep Sorrel is also troublesome in gardens.

Remedy: Sheep Sorrel is said to be an index of soil character. It seems to thrive best on sandy or gravelly soils deficient in lime. An application of lime to slightly acid soils produces a more vigorous growth of cultivated crops and curtails the oppor- 
tunities of the Sorrel to grow and spread. Old meadows and pastures that are over-run with it and that cannot well be brought under cultivation may be pastured with sheep for two or three years to prevent it from seeding freely.

The seed is exceedingly difficult to separate from alsike seed, and lands foul with Sorrel should not be used for the production of this crop.

A three-year rotation of crops with good cultivation, including shallow plowing directly after hay crop and frequent cultivation until autumn to prepare for hoed crops, will keep Sheep Sorrel well under control even on lands that seem to be specially suited to its growth.

In addition to the application of lime and good cultivation, the liberal use of farmyard manure, plowing down clover or other green crops, or any other means of enriching the soil, will stimulate field crops to a more vigorous growth and thus do much to smother out and suppress this pest.

ALLIED SPECIES: Garden Sorrel (Rumex Acetosa L.) is a common field and garden weed in some parts of the Atlantic Coast provinces. It differs from Sheep Sorrel in its more erect habit of growth and its broader, arrow-shaped, oblong leaf, with the ear-like appendages directed downward.

"An old custom takes place in this parish called Goolriding which seems worthy of observation. The lands of Cargill were formerly so very much over-run by a weed with a yellow flower that grows among the corns, especially in wet seasons, called Gools and which had the most pernicious effects, not only upon the corns while growing but also in preventing their winning when cut down, that it was found absolutely necessary to adopt some effectual method of extirpating it altogether. Accordingly, after allowing a reasonable time for procuring clean seed from other quarters, an act of the baron-court was passed, enforcing an old act of parliament to the same effect, imposing a fine of $3 \mathrm{~s} 4 \mathrm{~d}$ or a wedder-sheep, on the tenants for every stock of gool that should be found growing among their corns at a particular day, and certain persons styled gool riders were appointed to ride through the fields, search for gool and carry the law into execution when they discovered it. Though the fine of wedder-sheep is now commuted and reduced to $1 \mathrm{~d}$ sterling, the practice of gool riding is still kept up and the fine rigidly exacted. The effects of this baronial regulation have been salutary beyond what could have been expected. Five stocks of gool were formerly said to grow for every stock of corn through all the lands of the barony and twenty thraves of barley did not then produce one boll. Now the grounds áre so cleared from this noxious weed that the corns are in high request for seed; and after the most diligent search the gool riders can hardly discover as many growing stocks of gool the fine for which will afford them a dinner and a drink." 


\section{* LADY'S THUMB (Polygonum Persicaria L.)}

Other English names: Persicary, Smartweed.

Introduced from Europe. Annual, stem erect, fleshy, nearly smooth, hairless. Leaves lance-shaped, pointed, nearly stalkless, the surface roughish, often dotted and marked with a dark triangular or round spot near the centre. The mode of flowering is an ovoid or short cylindrical spike, dense, erect, composed of pink or dark purple flowers.

The seed (Plate 72 , fig. 10) is about $1 / 12$ of an inch in diameter, ovate, heart-shaped, hollowed out on one side or roundly triangular, jet black, shining.

Time of flowering: July to September; seeds ripe by August.

Propagation: By seeds.

Occurrence: Common all over the country, especially in low fields and meadows.

Injury: Although Lady's Thumb and others of the Knotweeds and Smartweeds are widely distributed, they are not seriously noxious in most field and garden crops. Knotweed is most abundant in yards and along paths where the soil is well trodden. Smartweeds thrive best in a rich, moist soil and are usually plentiful in grain or clover fields where the crop has killed out. The seeds of Lady's Thumb, in particular, are common in clover seeds. Smartweeds, like many other weeds, help to perpetuate nuisances even more injurious than the weeds themselves. They harbour insects, particularly plant lice, and fungus diseases, such as mildews, smuts and rusts.

Remedy: Lady's Thumb should not be permitted to seed. The plants in clover seed crops should be hand-pulled or cut before coming into full bloom. Destroy the screenings that accumulate when grain is threshed or fanned. The seeds do not retain their vitality long, and by cutting the plants two or three times during the season for a few years the pest may be eliminated from waste places.

\footnotetext{
* Lady's Thumb very elosely resembles Pale Persicary, illustrated on plate opposite
} 
ALLIED SPECIES. The seeds of the following allied species occur in commercial seeds:-

Knotweed or Doorweed (Polygonum aviculare L.) accompanies civilized man everywhere. It is found along roads and trails, forming mats of spreading wiry, jointed stems, with a leaf, a pair of silvery scales and a small cluster of flowers at each joint; each flower producing a slender, reddish-brown, triangular seed, $1 / 12$ of an inch long.

Knotweed or Doorweed may be eradicated from lawns by repeated raking and close cutting. In the autumn the trodden soil may be loosened, without inverting it, to the depth of a digging fork. This should be followed in early spring by an application of well-rotted manure and a thick seeding of grass, including some of the coarser and more vigorous growing, though short-lived, species, such as perennial rye grass. A liberal application of salt on gravel walks will kill it.

Pale or Dockleaved Persicary (Polygonum lapathifolium L.). A common, tall-growing and rather aggressive weed among grain and clover on rich low land in all parts of eastern Canada. The seed (Plate 72, fig. 9) is $1 / 10$ of an inch long, more roundly heartshaped, chocolate brown, hollowed on both sides and never triangular.

Glandular Persicary (Polygonum pennsylvanicum L.). A larger seed (1/8 inch), sometimes triangular, blackish, closely resembling both of the preceding but more frequently bearing the remainder of the upper part of the pistil at the tip.

The evil results from permitting coarse-growing herbaceous weeds to thrive in nooks about farmyards, gardens, fences and other waste places arise mainly from the fact that these succulent plants are a breeding ground in summer, and a harbour during winter, for insect and fungus pests. Fences and waste places are evils that should be reduced to a minimum. Where it is not possible to eliminate them, the land should be made as clean as possible, seeded with vigorous growing grasses, and the weeds kept closely cut until the grass has full possession of the soil. 


\section{WILD BUCKWHEAT (Polygonum Convolvulus L.)}

Other English name: Black Bindweed.

Introduced from Europe. Annual. A twining vine with rather rough branching stems and thin, smooth, arrow-shaped leaves. Flowers greenish, drooping, on short slender stalks, in small clusters, arising from the axils of the leaves, and in loosely flowered terminal racemes. Calyx 5-parted, persistent.

The seed (Plate 72, fig. 11) is dull, black, triangular, about $1 / 8$ inch long, bluntly pointed at the apex and almost twice as long as broad, widest just above the middle; the germ is club-shaped, small, curved and lies along one angle of the seed in a groove. When found in commercial grain the seed is often without its black coat and appears naked, white, wax-like, with slightly rounded angles.

Time of flowering: From June throughout the summer, the seeds ripening irregularly from about the middle of July.

\section{Propagation: By seeds.}

Occurrence: General in cereal crops throughout Canada. Most prevalent in the Prairie Provinces.

Injury: A pest in fields of cereal grain. The vines twine about the stems for support and interfere with the reaping machinery. The crop, when matted with this weed, is more apt to lodge during a storm and when once down is not able to recover. Seeds embedded deeply in the soil germinate late in the season, when the general cultivation of hoed crops is no longer practicable. Thus the plant is a nuisance in fields of potatoes, field roots and corn, where it seeds freely in the autumn months. Although the seeds from the early bloom have ripened and dropped before or during the harvesting of grain crops, they are frequently present in large quantities in commercial wheat and oats. In addition to reducing the yield, the grading and market value of the grain is depreciated by their presence. 


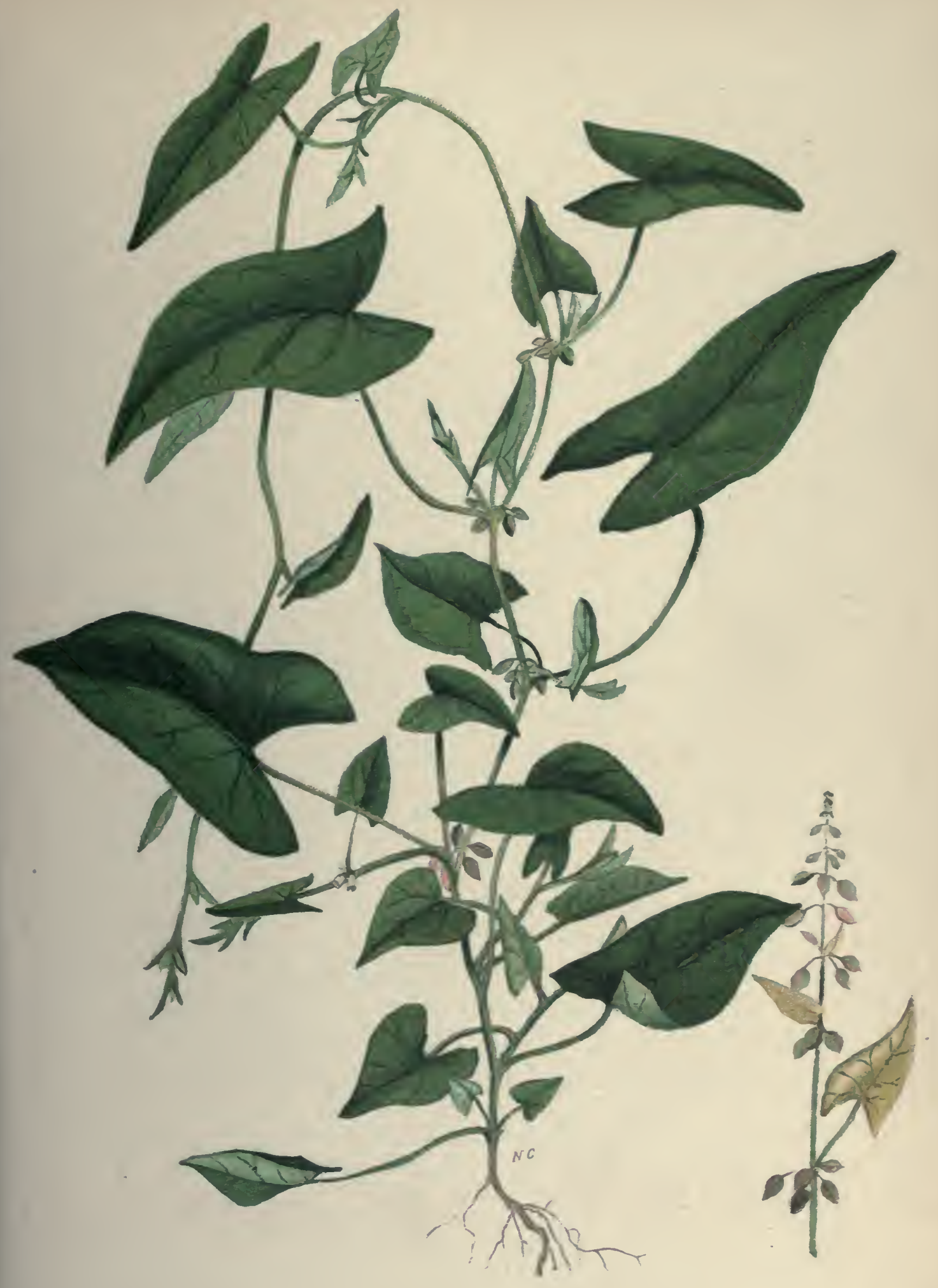

Plate 12

WILD BUCKWHEAT OR BLACK BINDWEED

(Polysonum Convolvulus \&.) 

Remedy: Sow clean seed grain. The seeds retain their vitality for a relatively short period, probably not longer than three years, except in the dryer soils of the western plains. The suppression of this pest is therefore largely dependent on the prevention of a continued supply of fresh seeds to the soil. This weed gives little trouble on land under a short rotation of crops, including hay for.two years.

The seeds of Wild Buckwheat do not germinate in the spring until the soil is quite warm. Most of the early plants can be destroyed in grain crops by an application of the harrow when the grain is about three inches high. The young plants soon root firmly and the harrowing, to be effective, must be done just as they emerge from the ground. Cultivation after harvest, as described for Wild Oats, will stimulate germination of the seeds that have dropped. A large proportion of Wild Buckwheat seeds can be induced to grow during the autumn and the seedling plants will be destroyed by frost. Plowing of summer-fallow should be done before any of the seeds have developed enough to ripen after being turned down and care should be taken to completely cover all the plants.

If given access to fields of corn or potatoes after cultivation has been discontinued, sheep will feed on the seedling plants and will do little injury to the crop.

The seeds of this weed have a feeding value only slightly inferior to cultivated buckwheat; but before being used for feed, screenings containing Wild Buckwheat or other weed seeds should be finely ground to destroy their vitality. Unless first carefully screened, oats that are simply "crushed" for feeding may contain large numbers of whole seeds of this pest, many of which are returned to the fields in a vital state.

I will go root away

The noisome weeds, that without profit suck The soil's fertility from wholesome flowers. 


\section{THE SPINACH OR GOOSEFOOT FAMILY (Chenopodiaceae).}

The Spinach family is widely distributed and contains some field crops and other valuable plants, as spinach and beetroot, as well as many troublesome weed pests. The plants adapt themselves to a variety of soils; they seem to thrive best on deep, rich, loamy land well supplied with mineral constituents.

They are more or less succulent herbs, mostly of erect habits of growth, with alternate leaves devoid of the rough appendages at the base of the leaf stalks, as are found in the Buckwheat family. The flowers are very small, generally green, and borne in clusters at the axils of the leaves, each flower producing a single seed.

The seeds, which are produced in enormous numbers, are enclosed in bladder-like envelopes called "utricles." The most important genera are: Chenopodium, Atriplex and Salsola.

\section{LAMB'S QUARTERS (Chenopodium album L.).}

Other English names: Pigweed, Fat-hen, White Goosefoot.

Introduced from Europe and native. Annual. Extremely variable in every character. Mostly tall, succulent and herbaceous, with a slender, erect, grooved, much-branched stem, 2 to 6 feet high, with angular-ovate, pale green, coarsely toothed leaves, narrowed at the base and borne on slender footstalks. Flowers in compound spikes from the axils of the leaves. The whole plant of a more or less white or pinkish mealy appearance. Plants late in the season are a much darker green and have less angled leaves.

The seed (plate 72 , fig. 12) is about $1 / 20$ of an inch in diameter, circular in outline, more or less flattened on one side, strongly convex on the other, edges bluntly rounded, the lower 
convex face grooved from the margin to the central scar, minutely wrinkled; colour shining black. The seeds, as found among crop seeds, have a thin envelope closely adhering to them, as a brown or gray mealy deposit, which gives them a granularroughened appearance; they also often have the dried 5-angled calyx closed tightly over them. When plants are cut or shaken roughly after the seeds are ripe, but while the plant is still green, the seeds fall out of the calyx very easily. Seeds from which the brittle black coat has been partially broken away, showing the yellow ring-like germ, may sometimes be found in screenings of grain.

Time of flowering: From June to frost; seeds ripe August to November.

Propagation: By seed.

Occurrence: Everywhere in rich land.

Injury: A gross feeder and a vigorous rapid grower in field and garden crops. It is most conspicuous in fields of potatoes, corn, and other hoed crops, where the seeds germinate and the rapid-growing plants mature after general cultivation has been discontinued. The succulent plants are a harbour for plant lice and other insects destructive to field and garden crops, particularly to mangels. They also provide a breeding ground for mildews and for the spot fungus disease (Cercospora) common on the leaves of beets and mangels. The seed is abundant in commercial seeds and grains.

Remedy: The seeds germinate at considerable depth in the soil, and those buried deeply do not retain their vitality for more than three or four years, unless the soil continues very dry. In eastern Canada, land badly infested might be seeded to grass for three years or more. An application of the harrow to cereal grain fields before the crop appears above the ground, and again when it is three inches high, will destroy most of the seedling plants. If the field is to be seeded to clovers and grass, the seed should be sown quite thickly directly in front of the harrow. Sheep readily eat the leaves of the plant and the seedlings. Seed-bearing plants should be pulled and removed from the clover seed crop before it is cut. Late plants in hoed crops 
should be cut with a hoe from time to time during the summer. In western Canada, the harrowing of the grain crops, combined with periodic clean suminer-fallowing, will keep this weed in check.

ALLIED SPECIES: Maple-leaved Goosefoot (Chenopodium hybridum L.). A plant very similar to Lamb's Quarters, with large green, very coarsely 2 to 6 -toothed leaves. Its seed is larger ( $1 / 15$ of an inch in diameter), of exactly the same appearance as that of Lamb's Quarters, and is sometimes found in crop seeds.

\section{RUSSIAN PIGWEED (Axyris amarantoides L.).}

Introduced from Europe. Annual. A tall, coarse plant, from 2 to 4 feet high, erect and widely branching, very leafy. When young much like Lamb's Quarters, but paler green with a more wand-like habit of growth, and, instead of being mealy in appearance it has soft, short, star-shaped hairs. When fullgrown the whole plant forms a large pyramidal compound raceme; the stems, bracts and the papery calyx segments turn white and make it very conspicuous.

The seed (Plate 72, fig. 15) is oval, flattened, 1/12 of an inch long, gray or brown with a silky lustre, surface minutely lined and wrinkled lengthwise, basal scar a short thin groove across the lower end; many seeds have a close-fitting papery envelope, projecting above the top as a 2-lobed wing.

Time of flowering: June; seeds ripe July-August.

Propagation: By seeds.

Occurrence: The species was first noticed in Canada in 1886, by the roadside at Headingly, Man., 14 miles west of Winnipeg, where it is said to have been brought direct from Russia. It is now found along the railways throughout the West, and has even been detected on a railway bank as far east as St. John, N.B. 


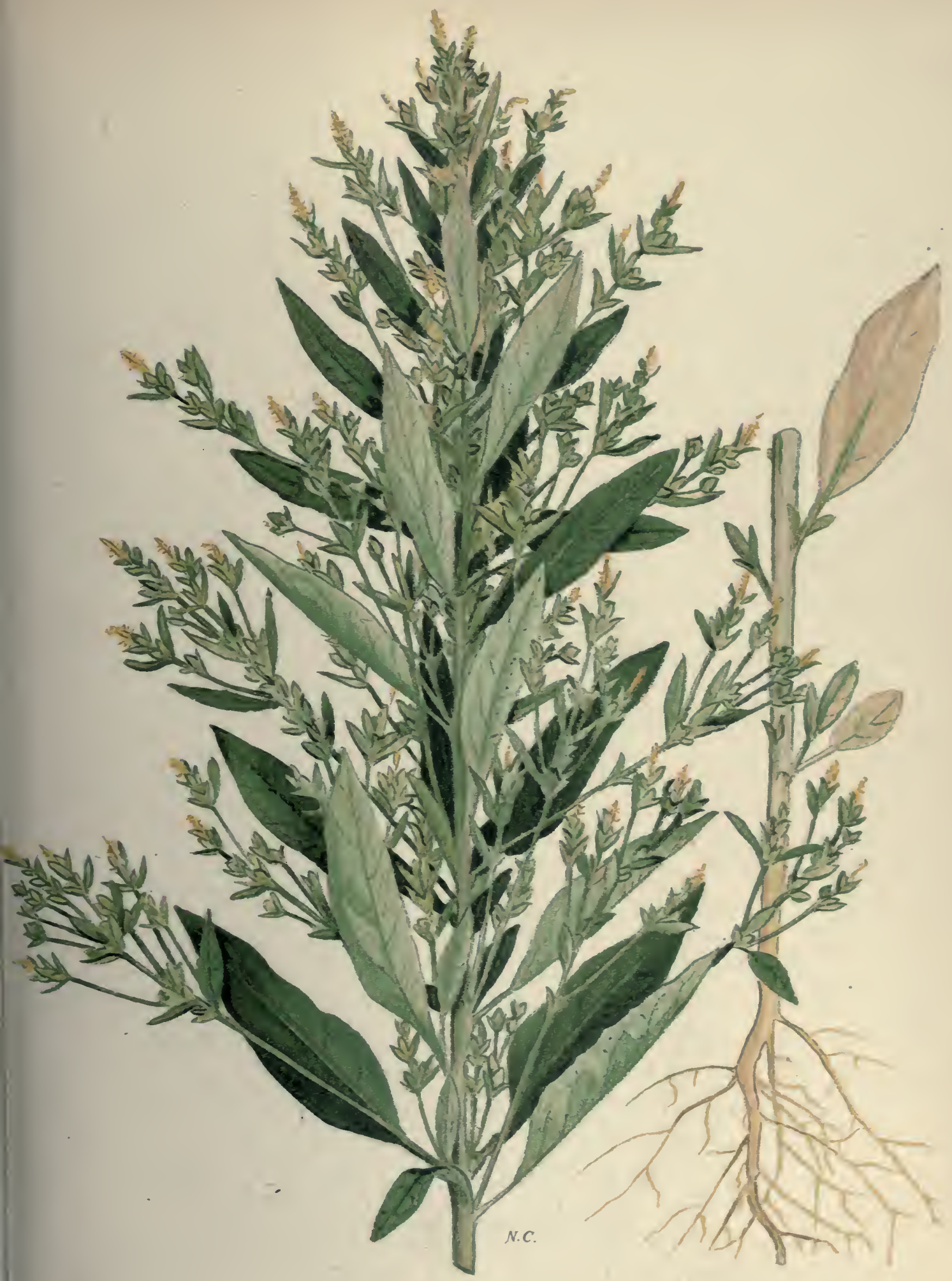

Plate 14

RUSSIAN PIGWEED

(Axyris amarantoides 1. ) 

Injury: A leafy, gross-feeding, wide-rooting annual, which crowds growing crops and gives a weedy appearance to farm lands: The thick woody stems are troublesome when crops are harvested. The abundant seeds, somewhat like small, gray, flax seeds, are found in grain from a few districts infested by this rank-growing weed. It is therefore important that it should be prevented from spreading from roadsides and waste places, as it has every characteristic of an aggressive enemy. Like Lamb's Quarters, it harbours injurious insects and fungus pests common to the cultivated species of the same family.

Remedy: Waste places should be made as clean as possible and thickly seeded to grass; weeds should be kept cut until the grass has taken complete possession of the soil. Infested fields should be thoroughly summer-fallowed and the succeeding grain crops treated with the harrow, as recommended for Lamb's Quarters. Seeding to grass for five or more years will do much to suppress this pest by destroying the vitality of the seeds. Hand-pulling should be employed to prevent scattered plants from maturing their seeds; a single plant is capable of producing as many as twenty-five thousand seeds.

The sixth help of Ground is, by Watring and Irrigation, which is in two manners; The one is by Letting in, and Shutting out Waters, at seasonable times; for Water, at some seasons, and with reasonable stay, doth good; but at some other seasons, and with too long stay, doth hurt. And this serveth only for Meadors, which are along some River. The other way is to bring Water from some hanging Grounds, where there are Springs, into the lover Ground, carrying it in some long Furroves; and from those Furroves, drawing it traverse to spread the Water: And this maketh an excellent improvement both for Corn and Grass. It is the richer, if those hanging Grounds, be fruitful, because it washeth off some of the fatness of the Earth; but howsoever it profiteth much. Generally where there are great overflows in Fens, or the like, the drowning of them in the Winter, maketh the Summer following more fruitful: The cause may be, for that it keepeth the Ground warm, and nourisheth it. But the Fen-men hold, that the Severs must be kept so, as the Water may not stay too long in the Spring till the Weeds and Sedge be grown up; for then the Ground will be like a Wood which keepeth out the Sun, and so continueth the wet; whereby it will never graze (to purpose) that year. 
RUSSIAN THISTLE (Salsola Kali L. var. tenuifolia G.F.W. Mey.).

Other English names: Russian Tumbleweed, Russian Cactus. Mog.

Other Latin names: Salsola Tragus L.,Salsola Kali var. Tragus

Introduced from Asia. Annual. Bushy, of a prickly appearance, due to the long, thin, thread-like, prickle-tipped leaves which characterize the young plant, and the short, triple, spiny bracts on the flowering branches of the older plants. It varies in appearance at different stages of growth. The young plant is dark green; the slender leaves, about two inches long, drop off soon after the seed is formed. The somewhat spherical branched top of the mature plant, when broken away from the root, is blown about by the wind and scatters its seeds widely. It is not a thistle and could be more appropriately called a tumbleweed. Flowers solitary, borne in the axils of the leaves.

The seed (Plate 72 , fig. 13 ) is about $1 / 16$ of an inch in diameter, cone-shaped, the large end concave with a well marked protuberance in the centre of the cavity. The coat is thin and transparent, showing the grayish-brown, coiled germ. It is generally enclosed in a papery envelope, the divisions of which are winglike and help to disseminate the seed.

Time of flowering: July to September; seeds ripe by August.

Propagation: By seeds. The seeds are distributed by the tumbling plants, which are driven by the wind. As the seeds do not shell readily, they are carried long distances.

Occurrence: Abundant in several localities in the dryer parts of southern Alberta and Saskatchewan, chiefly along roadsides, fire-guards and in neglected fields. Frequently found, though not seriously troublesome, in the eastern provinces.

Injury: Russian Thistle is a large, succulent weed and thrives where the land is too dry for other plants. It thus uses up moisture where it is.scarcest and most needed. Owing to 
its stout woody character and sharp spines, it is almost impossible for horses to work where it abounds, unless their legs are well protected. It is hard on harvesting machinery and wasteful of binder twine.

Remedy: Hand-pull wherever practicable. Harrowing growing crops is an effective remedy; it is easily killed when young by this method. The harrow should be applied just before the grain emerges from the ground and again when the crop is three inches high.

Where winter wheat is grown successfully, there is little difficulty with Russian Thistle, as it is very susceptible to frost and plarits started in late summer will be destroyed before they produce seed. Spring crops should never be sown on land that contains live Russian Thistle seeds unless there is sufficient moisture in the soil to produce a vigorous growth. Scientific dry farming, with a well tilled summer-fallow every third year, will conserve the moisture in the soil so that the crops will be strong enough to crowd out the Russian Thistle. Work on summer-fallow should begin early, not only to conserve the moisture but because these plants, if allowed to become full grown, are so cactus-like as to make it almost impossible to put horses among them.

For thilke ground, that beareth the wedes wick, Beareth eke these holsome herbes, as full oft Next the foule nettle, rough and thick,

The rose wexeth, soote, smooth, and soft, And next the valey is the hill a loft, And next the derke night the glad morrowe, And also joy is next the fine of sorrow.

-Geoffey Chaucer, Troilus and Crescide, 1350.

Columella, author of De Re Rustica, written in the first century A.D., says "if these (weeding and sarcling - a kind of hoeing) are neglected, the produce of the fields will be greatly diminished; in my opinion he is a very bad farmer who allows weeds to grow along with corn: for the produce will be greatly lessened if weeding is neglected." 


\section{THE PIGWEED FAMILY (Amaranthaceae).}

The Pigweeds are a small family of plants, mostly of tropical origin, closely allied to the Spinach family. Each plant produces enormous quantities of small, highly-polished, lens-shaped, more or less margined seeds. The flowers are small and inconspicuous; leaves simple and borne on a stalk. Some of the exotic members of this family are gorgeously coloured and are grown for their ornamental foliage or flowers, as the Cockscombs (Celosia), Rainbow Amaranth (Amaranthus tricolor L.) and the well-known Love-lies-bleeding (Amaranthus caudatus L.).

The seeds are borne singly, as in the Spinach family, enclosed in a thin, cartilaginous covering known botanically as a "utricle." Unless closely examined, they may sometimes be confused with rubbed seeds of Lamb's Quarters. The surface of the Pigweed seeds is always more highly polished and smoother. The scar is the easiest point for distinguishing them; this is a central point, with a long groove on one side, in Lamb's Quarters and a notch in the margin in the Pigweeds.

\section{REDROOT PIGWEED (Amaranthus retroflexus L.).}

Other English names: Rough Pigweed, Chinaman's Greens.

Introduced from tropical America. Annual, with a rosypink tap-root. Stems erect, simple or branched, rough hairy. Lcaves on long stalks, ovate, bristle-pointed. Flowers inconspicuous, numerous, erowded into thick compound spikes at the ends of the branches and in the axils of the leaves. Bracts of the flowers, bristlc-pointed, longer than the green calyx divisions.

The seed (Plate 72, fig. 14) is highly polished, reddish black to jet black, about the same size as that of Lamb's Quarters. 
circular or egg-shaped in outline, much flattened and equally convex on both sides. An immature or shrunken seed has a narrow, slightly flattened marginal band, which marks the location of the ring-like germ. The basal scar appears, as a light point on the edge of the seed separating the ends of the germ.

Time of flowering: July to September; seed ripe by August.

Propagation: By seeds.

Occurrence: In all crops. Thoroughly established in all the settled portions of the Dominion. Abundant in waste places around farm buildings and in gardens. Widely spread by the seeds, which occur commonly in all commercial seeds.

Injury: A pestiferous weed in gardens and fields; especially troublesome in potato and field root crops. It is a coarse, vigorous grower, and when it has attained to full size, is difficult to destroy by pulling or cutting. A medium-sized plant will produce fully twelve thousand seeds.

Remedy: When embedded in the soil, the seeds retain their vitality for several years, though probably not more than five in a moist soil, and produce seedling plants only when brought by cultivation within about two inches of the surface. Late cultivation in hoed crops should be made as shallow as practicable; after general cultivation is discontinued, plants of this and other weeds that have escaped should be cut with the hoe from time to time during the late summer months. Like other annual weeds, it can rapidly be suppressed by preventing the production of a fresh supply of seeds.

ALLIED SPECIES: Green Amaranth (Amaranthus hybridus L.) is quite similar to Redroot Pigweed, but smoother and deeper green in colour, with spikes more slender-cylindrical, and bracts with rather long awns. The seed is much like that of Redroot Pigweed and, although averaging rather smaller, about $1 / 32$ of an inch in diameter, can not always be distinguished from it when found among crop seeds. 
Tumble Weed (Amaranthus graecizans L.) is another Amaranth very abundant throughout the country, but particularly so in the West. It is a bushy annual, branched, erect or creeping, but not rooting at the nodes, with whitish stems and small oval leaves, gradually narrowed towards the base. Small clusters of flowers or fruits are borne in the axils of most of the leaves. When mature, these plants break off at the ground and are blown long distances by the wind, scattering their seeds as they go.

Spreading or Low Amaranth (Amaranthus blitoides Watson). This species resembles Tumble Weed, but has rather larger, rounder leaves with prostrate, diffusely branching, somewhat fleshy stems, which form large mats attached to the central root. This is a native of the western prairies but is frequent along railways in the East. The seed, which is often found in alfalfa, clover and grass seeds from the western states, can be easily distinguished from that of Tumble Weed by its larger size, $1 / 15$ of an inch in diameter, which is nearly twice that of the other species. It is the same size as Maple-leaved Goosefoot seed.

The darnel, hemlock, and rank fumitory,
Doth root upon,...... and nothing teems
But hateful docks, rough thistles, kecksies, burs,
Losing both beauty and utility.
And as our vineyards, fallows, meads, and herlges,
Defective in their natures, grow to wildness;
Even so our houses, and ourselves, and children,
Have lost, or do not learn, for want of time,
The sciences that should become our country.
-Shakespeare, Henry V, Act V, sc. ii, 1599.

Weeds are nourished by the same food that would nourish useful plants; and therefore, when allowed to grow along with them, must rob them of part of their food. Altho' it is allowed, that the food of all plants is not exactly of the same kind; yet as plants take in whatever juices, or sinall particles of matter are touched by their roots, it may be justly said, that all kinds deprive the earth of that vegetable food which would nourisl others. Experience convinces the farmer of the truth of this; for he finds, that his crop is barl in proportion to the quantity and kinds of weeds with which his land is infested. 


\section{THE PINK FAMILY (Caryophyllaceae).}

The Pink family is widely distributed all over the world, most of its members however belonging to the temperate and cold climate. It contains several beautiful garden flowers, amongst them the innumerable kinds and varieties of carnations, and also embraces some troublesome weeds, the seeds of which are frequently found in clover and grass seeds. The characters of all the weeds belonging to the Pink family are well marked. They are herbs with brittle stems, articulated and thickened at the joints, frequently forked. Leaves without teeth or divisions, generally opposite and joined round the stem at the base. The flowers are regular. The calyx is always persistent and the corolla sometimes wanting. The fruits are capsules or pods.

The seeds, usually many, are attached to the base or to : central column of the solitary 1-celled, (rarely 3 to 5-celled) toothed pod, which opens at the top. They are often kidneyshaped and embossed with tubercles. The germ in most of the seeds is curved so that the apex and base come close together. The seeds do not develop mucilage when soaked in water.

They are covered with a hard protective coat, through which the water will penetrate slowly, thus keeping the vitality of the seed and delaying its germination for many years when embebbed in the soil.

They are two tribes of these plants: the Chickweeds (Alsineae), low herbs in which the calyx divisions are distinct or nearly so, and the corolla divisions provided with short claws; and the Cockles (Sileneae) with large and showy flowers, with the corolla divisions united in a tube and provided with long claws.

The plants belonging to the genera Saponaria and Agrostemma are said to possess a poisonous principle (sapotoxin) to a greater extent than the other members of the Pink family. It is 
a matter of common observation that all the members of this large family possess a pungent flavour objectionable to all classes of live stock, and the presence of the plants, either in pastures or in cured fodder, entails considerable waste. Definite information as to the baneful effects, if any, resulting from the consumption of the plants or the seeds is not available, although it is known that wheat screenings, composed largely of cockle seeds, are ground with coarser grains and sold as feeding stuffs.

\section{SPURREY (Spergula arvensis L.).}

Other English names: Corn Spurrey, Sandweed, Pickpurse.

Introduced from Europe. Annual. Stems curving upward, branching from the base, 6 to 18 inches high, almost smooth, sparingly hairy above. Leaves narrowly linear, 1 to 2 inches long, apparently in a circle around the joints of the stem but really in two opposite sets of 6 to 8 together, with scale-like, modified leaves between them. Flowers white, opening in sunshine, $1 / 4$ inch across, in terminal forked cymes; the fruit hanging abruptly downward.

The seed (Plate 72, fig. 16) is dull black, lens-shaped or round and compressed, with the margin extended into a narrow pale wing. The surface is more or less roughened with small, palecoloured, elongated protuberances, like gland-tipped hairs. Both the small protuberances and the wing are sometimes absent when the seeds occur among commercial seeds.

Time of flowering: July; seed ripe July-August.

Propagation: By seeds.

Occurrence: Frequent in grain fields in the eastern provinces and in parts of British Columbia and occasional in fields and 

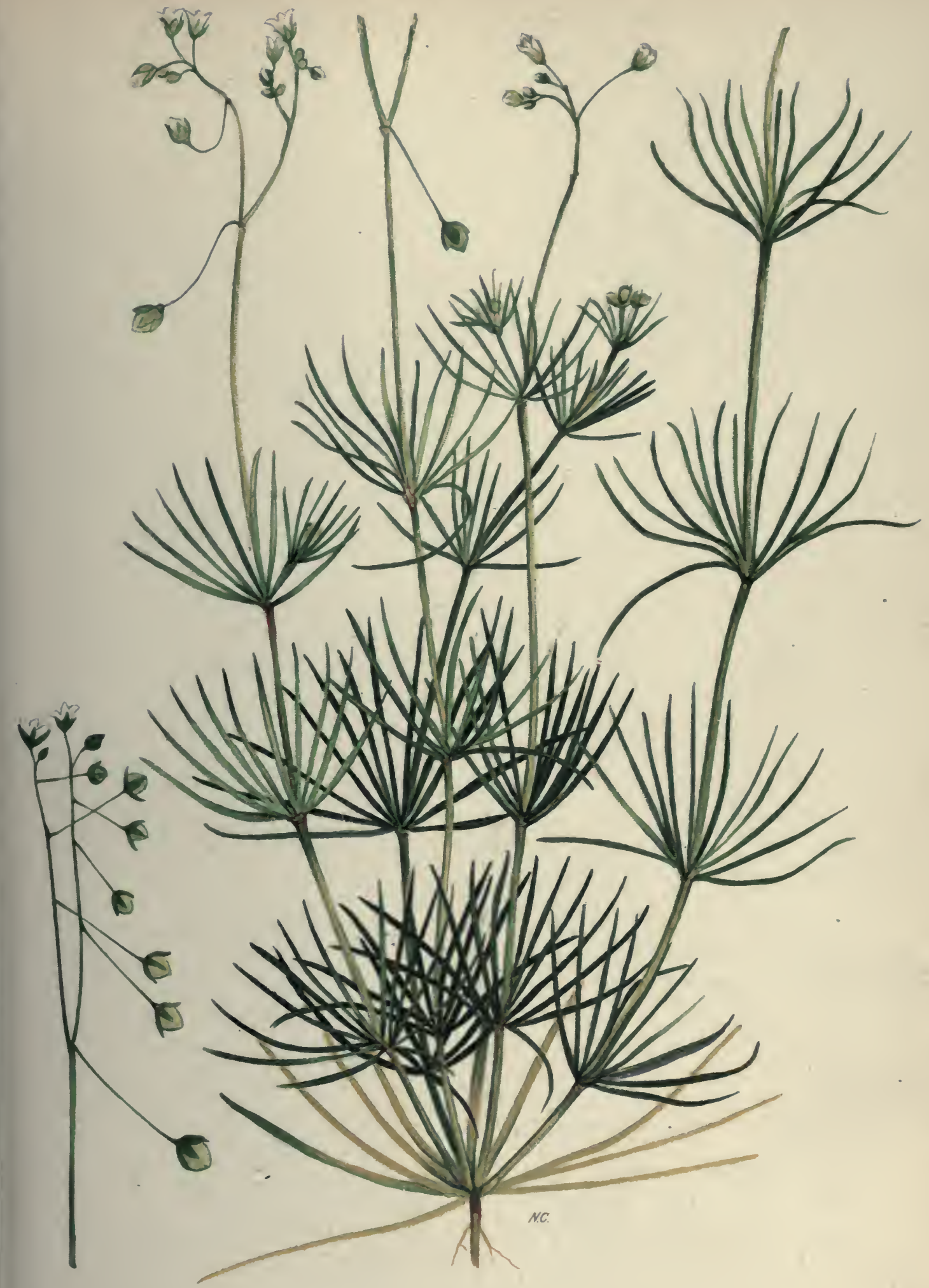

Plate 17

CORN SPURREY

(Spergula arvensis $L_{\text {. }}$ ) 

waste places throughout Canada. Sometimes sown as feed for sheep or as a binder of soil on sandy land.

Injury: Troublesome on sandy soils in the eastern provinces and the Pacific coast. Common in grain and clover fields. The seed is a frequent impurity in grass and clover seeds and cereal grains grown on lands infested with it. Spurrey is cultivated as a forage crop on some of the light, sandy soils of European countries. When sown in the fall it produces a large yield of fodder for spring feeding. It is said to be a nutritious food and liked by cattle and sheep when once they have become accustomed to it.

Remedy: The seeds are produced in abundance and mature early. An application of the weeder or harrow destroys seedling plants in the spring grain. Spurrey will not give serious trouble on lands worked under a systematic crop rotation. Shallow cultivation of stubble lands will start germination and the young plants can be easily destroyed in cultivating for spring seeding.

\footnotetext{
Some the hoe prefer,

Which female hands, or, if of lighter make,

The childish grasp can wield; even his small hands,

Of years so simple, that he grieves to hurt

The pretty flowers, which, strung about his neck,

He wears with more delight than kings their crowns.

Thus too, the crop itself (soon as the plants

Four leaves spread fully forth) is duly thinned.
}

-James Grahame, British Georgics, 1 S12.

We ought to learn more about each plant than we do, the time of its appearance and flowering, what it does with itself in the winter, whether dropping its leaves.... or disappearing beneath the ground like Snowdrop or Hyacinth, or facing the cold with a tuft of leaves Iying close upon the earth like a Foxglove. What sort of locality does it love-field, marsh, rock? How does it treat other plants when it encounters them? Does it twine round them like a Convolvulus, creep over them like many trailing plants, or bear itself erect like a Buttercup? How does it wither? Shabbily and untidy like the Pansy, or in the neat, decorous mode of the Gentianella? These and all other facts which we can learn about a plant have a value in an imaginative point of view; they tell us something about it, and so enable us to understand it, to read its true meaning and character. 
COMMON CHICKWEED (Stellaria media (L.) Cyrill.).

Other English name: Chickweed.

Other Latin name: Alsine media L.

Introduced from Europe. Annual. Succulent, stems diffusely branching, curving upward with a tendency to lie down. Roots, hair-like and exceedingly tough. Leaves ovate, the footstalks of the lower ones hairy on the margin. Stems bearing a conspicuous stripe of articulated hairs down one side. Flowers $1 / 4$ inch in diameter, star-shaped, numerous, solitary from the axils of the leaves, in old plants in terminal leafy cymes; corolla white, about the length of the thin-margined calyx. Fruit capsules, cone-shaped, spreading or hanging down, longer than the calyx.

The seed (Plate 72, fig. 17) is small, $1 / 24$ of an inch in diameter, yellowish brown to dark brown, wedge-kidney-shaped, flattened and covered with coarse tubercles arranged in regular curved rows, about 5 on each side and 4 on the edge.

Time of flowering: At all times of the year except during frost; seed ripening continuously.

Propagation: By seeds.

Occurrence: This well-known little weed occurs in all parts of Canada where the soil is moist and rich.

Injury: A persistent grower, most troublesome in garden and field hoed crops. Its habit of seeding early and throughout the season, combined with the protective seed coat which cnables the seed to retain its vitality for several years, makes it an exceedingly difficult pest to exterminate. The seeds are frequently present in grass and clover seeds. Chickweed harbours plant lice.

Remedy: This weed can be suppressed by clean eultivation of hoed crops - the last general cultivation should be shallow, so as not to bring a fresh supply of seeds to the surface-and discing of bare stubble lands directly after harvest, to check 


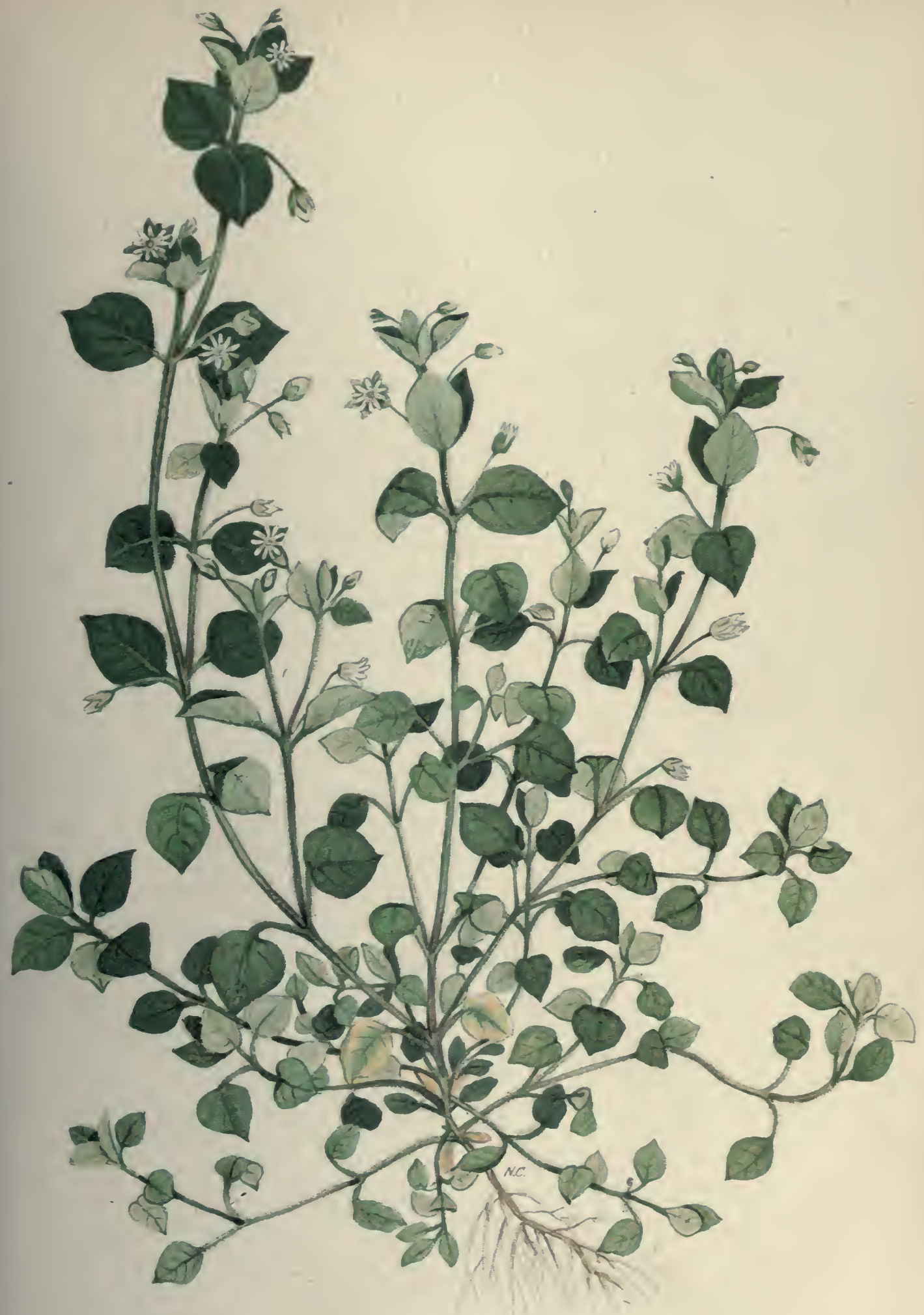

Plate 18

COMMON CHICKWEED

(Stellaria media (ujortil) 

further seeding. Good drainage of infested areas is also helpful. Thick seeding with clovers and grasses is effective in smothering it out.

ALLIED SPECIES: Grass-leaved or Lesser Stitchwort (Stellaria graminea L.) is a weed found occasionally in the Maritime Provinces. It is a wide-branching plant, 1 to 2 feet high, with many grassy leaves in pairs along the slender stems and bearing many starry white flowers nearly $1 / 2$ inch across.

The seed is often found in clover and grass seed; it is the same size as Common Chickweed seed but more nearly circular in outline. The surface markings are quite different; instead of bearing tubercles, the surface is thickly covered with short curved ridges in more or less regular rows.

The Mouse-ear Chickweeds (Cerastium), two or three of which occur in Canada as weeds, are somewhat similar to Common Chickweed but easily distinguished from it. These plants have much the same habit of growth as Common Chickweed but are covered all over with downy hairs, which in some species are glandular, giving a dirty appearance to the plants by reason of the dust which adheres to them.

Field Mouse-ear Chickweed (Cerastium arvense L.) in some places is a troublesome and persistent weed. A native form occurs abundantly throughout the western prairies but gives little trouble. In some parts of Ontario, Quebec and the Maritime Provinces there is a kind with smoother leaves, and copious rootstocks which enable the plant to become a persistent enemy. Pastures or meadows invaded by it must be broken up and cleaned by a short rotation of crops. The flowers of Field Chickweed are large and conspicuous, more than $1 / 2$ inch across, and borne on erect flowering stems, 3 to 6 inches high. In the West the plant is sometimes grown for its beauty.

The seed is larger than that of the other chickweeds here described, almost round and covered with coarse tubercles.

Common Mouse-ear Chickweed (Cerastium vulgatum L.) is a perennial plant which occurs in cultivated land, pastures and 
lawns throughout Canada. The pods are much elongated and curved upwards.

The seed (Plate 72, fig. 18) resembles that of Common Chickweed but the tubercles are fewer, less regularly arranged, and more of the nature of short ridges than of low prominences, as in the former species. It is rather more angular and not much more than half the size.

\section{PURPLE COCKLE (Agrostemma Githago L.).}

Other English name: Corn cockle (used in England, where cereals are generally spoken of as "corn").

Other Latin name: Lychnis Githago Scop.

Introduced from Europe. Annual and winter annual. Erect, 1 to 3 feet high; branches few; whole plant covered with soft, silky hairs; not viscous. Leaves 2 to 5 inches long, narrow and pointed. Flowers purple, borne at the tips of the stems and branches, $1 \frac{1}{2}$ inches across; the corolla divisions notched at the apex, paler toward the centre; calyx ovoid, much swollen in fruit, with the ribs prominent and the teeth long and conspicuous. Fruit capsule ovoid, with 5 teeth at the apex.

The seed (Plate 72 , fig. 19) is pitchy black, from $1 / 12$ to $1 / 8$ of an inch in diameter, somewhat flattened, rounded triangular; the thin edge notched by the scar of attachment; rough, covered with rows of short teeth.

Time of flowering: July; seed ripe in August.

Propagation: By seeds.

Occurrence: In grain throughout Canada.

Injury: A weed common to wheat fields and other cereal crops. It is difficult to separate the seeds from wheat without a heavy loss of the grain. When ground with wheat, the seeds give the flour a dark colour and a bad flavour. Bread made from wheat infested with this and other cockle seeds is unwhole- 


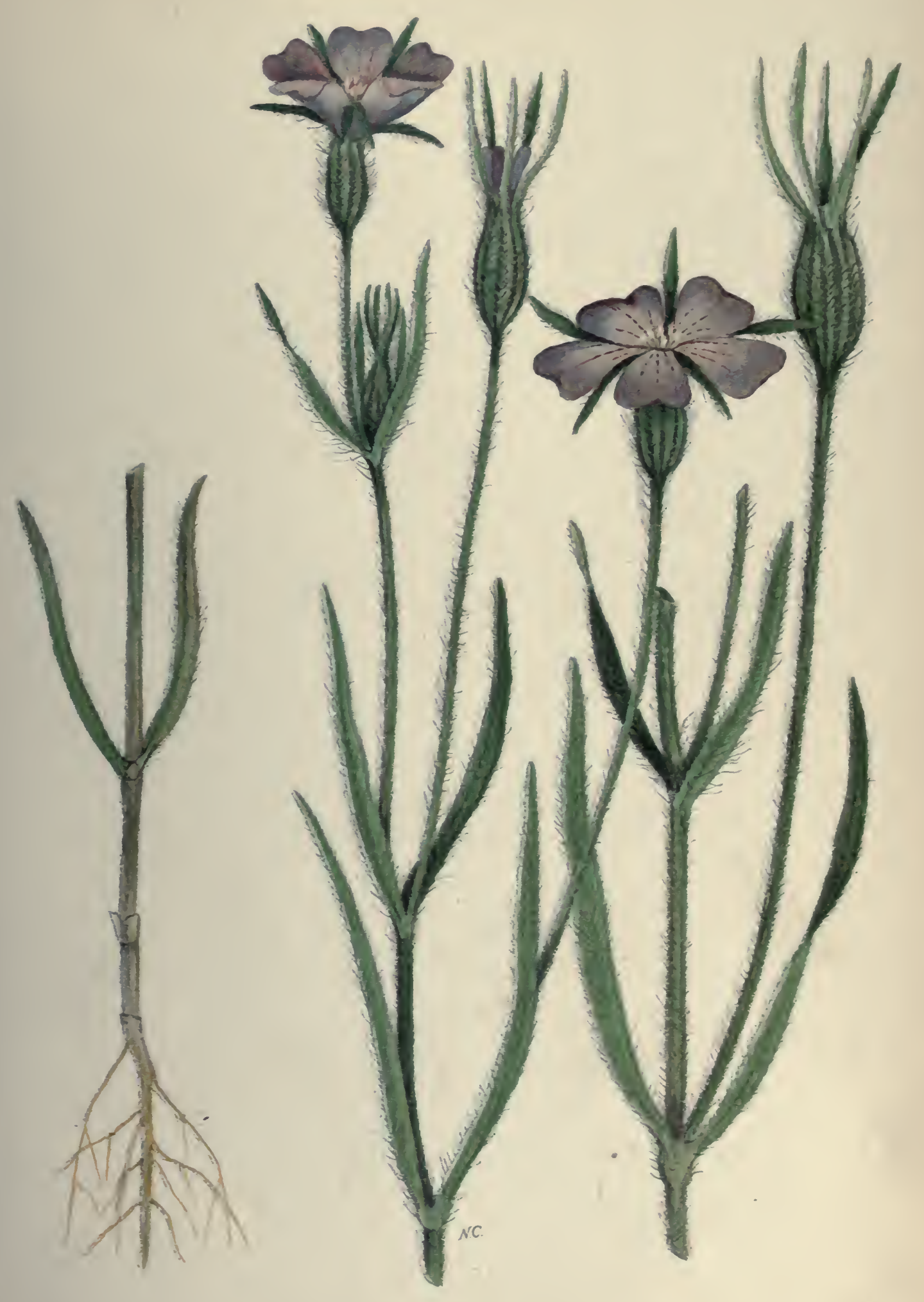

Plate 19

PURPLE COCKLE OR CORN COCKLE (Agrostemma Githago L) 

some owing to a poisonous principle in the plant and seeds. When eaten in quantity, the seeds are poisonous to young chickens.

Remedy: Sow clean seed wheat. It is quickly suppressed and ultimately eradicated on lands brought under a short rotation of crops. In eastern Canada, when this weed is abundant, wheat should be omitted from the rotation for four years.

In the Prairie Provinces, harrowing the grain crop just before it emerges from the ground and again when it is three inches high keeps down this weed. Where the land is infested with Purple Cockle, a thorough summer-fallow is the best method of getting rid of it. Preparation for a summer-fallow should start in the fall, by cultivating the land immediately after harvest. This can be accomplished by having the dise follow immediately behind the binder and thus cultivate the open strip between the standing grain and the sheaves. Early in the spring the land should again be disced or harrowed, to start the weeds as early as possible. The plowing should be deep and should be begun as soon as seeding is completed and finished not later than the end of June. Harrow immediately after plowing and repeat from time to time during the summer. Hand-pull any Purple Cockle that may be found in the crop after the summer-fallowing. Hand-pulling is also practicable when this weed first makes its appearance.

Besides the plough and hoe, the sweeping scythe Will much avail to wage the weeding war. If o'er your leas the yellow ragwort spread A gaudy forest; or the seedy dock

Uprear its stalk prolific; or the tribe Of thistles fenced with prickly arms,-spare not

The emblem dear, but ruthless lay it low, With all its brother cumberers of the ground: For, if allowed to stand, the down-winged seed Flies far, a pastime to your playful elves, To you a cause of meikle loss and bale. Let none of all the intrusive race even form

-Their seed; for know-the fructifying stage Of vegetation most exhausts the soil;

And, though cut down before they shed their fruit, Mixed with the compost mound, they but create

A magazine of poisons for your fields. 


\section{WHITE COCKLE (Lychnis alba Mill).}

Other English names: Evening Lychnis, White Campion.

Other Latin names: Lychnis vespertina Sibth.; Silene pratensis Godr. \& Gren.

Introduced from Europe; sparingly distributed in Ontario. Biennial or short-lived perennial. Rootstock thick, sending up a few short barren shoots and long branching flowering stems, 1 to $2 \frac{1}{2}$ feet high. Whole plant rather viscous hairy but not so much so as Night-flowering Catchfly. It resembles the latter somewhat, but is wider branching, has many stems, the leaves are larger, the flowers more numerous, pure white, and with a more conspicuous crown of short white scales around the centre; the male and female flowers are on separate plants. The fruit capsule has 10 teeth at the top instead of 6 , as in Night-flowering Catchfly, and is much larger and more swollen.

The seed (Plate 72, fig. 20) is pale gray, about as large as that of Bladder Campion and Night-flowering Catchfly. It is roughened by regular concentric rows of tubercles, which are farther apart than those characteristic of allied species. The point of attachment of the seed is usually depressed.

Time of flowering: June; seeds ripe in July.

Propagation: By seeds only.

Occurrence: Grain crops and meadows. White Cockle is not a common weed in Canada but has been introduced occasionally with seeds imported from Europe. In the vicinity of Guelph it is abundant and troublesome.

Injury: A persistent weed that is exceedingly difficult to eradicate, once it is established; a nuisance in all field crops. The seeds are common in grass and clover seed from land where the weed is plentiful. 


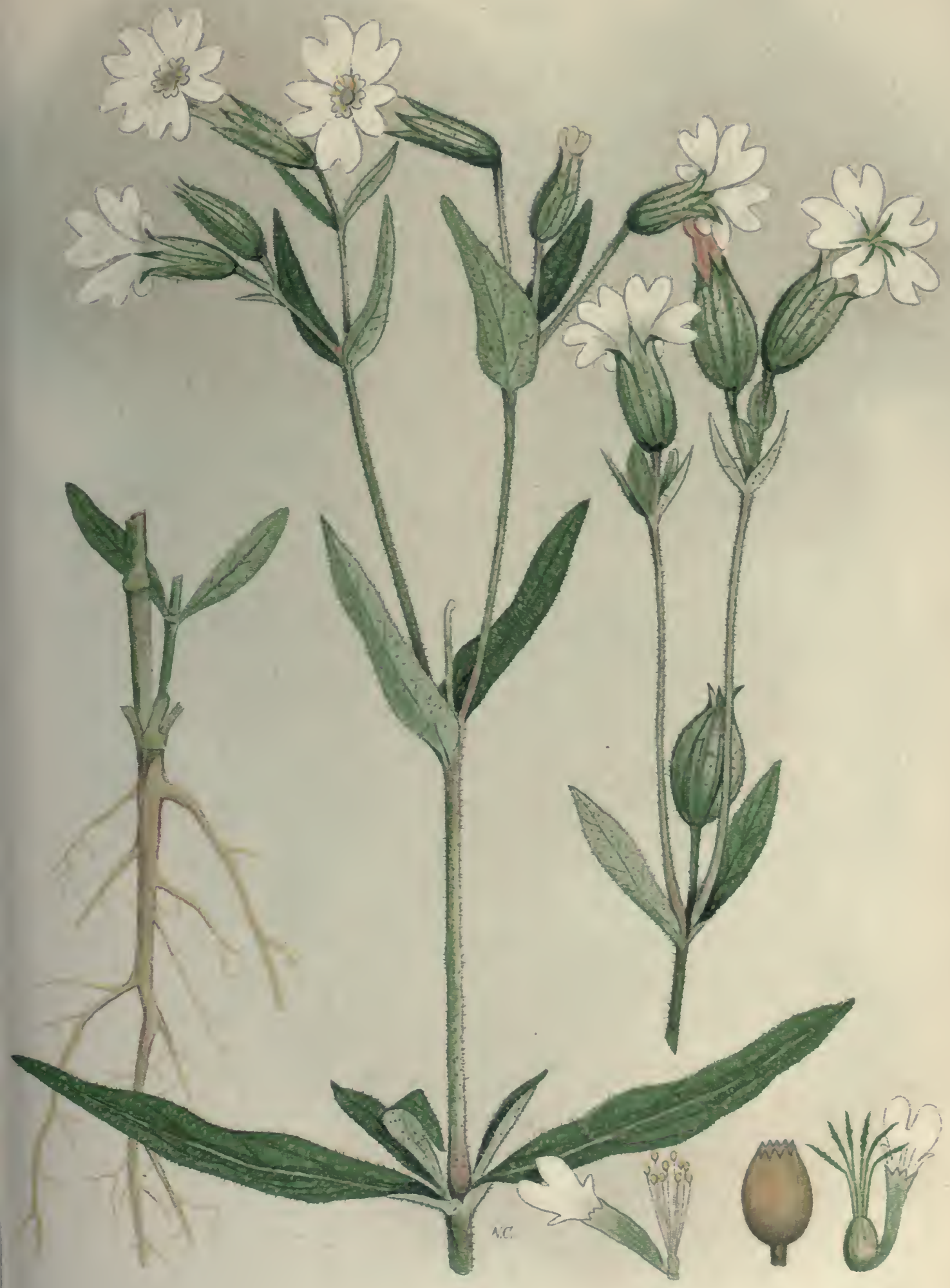

Plate 20

WHITE COCKLE

(Lychnis alba $.1 / 2 l l$ ) 

Remedy: A bare summer-fallow, with thorough cultivation, will suppress it. Prof. G. E. Day, of the Ontario Agricultural College, Guelph, states that the roots are fleshy and hard to kill unless dragged right up to the surface of the soil. If there is a little earth covering any part of them, they will continue to grow and try to produce seed. When spudded below the surface, they will grow again but do not produce seed that season. A short rotation of crops will keep it in check. Discing bare stubble will help prevent it from seeding late in the season. Thick seeding with clovers will restrict it by smothering. Pastures following a single cut of early clover should be trimmed with a mower about the middle of August to prevent the maturing of seeds.

ALLIED SPECIES: Several species that are found growing as weeds have escaped from gardens.

Dusty Miller (Lychnis coronaria (L.) Desr.) is a showy plant with crimson flowers and white foliage.

Ragged Robin (Lychnis Flos-cuculi L.) is occasionally met about old gardens in the Maritime Provinces. It has a slender stem and rose or pink flowers, the corolla divisions 4-cleft.

Scarlet Lightning (Lychnis chalcedonica L.) is also sometimes found naturalized in localities where it has escaped from cultivation.

Red Campion (Lychnis dioica L.) is a coarse, hairy, somewhat viscous plant, quite common in some localities in the eastern provinces where it has become naturalized, apparently from cultivated forms.

Drummond's Pink (Lychnis Drummondii Hook. Wats.) is characterized by narrow leaves, small pink flowers, and a stem almost leafless above; quite common in Manitoba.

All weeds, as such, are pernicious, but some much more than others; some do more injury, and are more easily destroyed; some do less injury and are harder to kill; others there are which have both these bad qualities. 


\section{NIGHT-FLOWERING CATCHFLY (Silene noctiflora L.)}

Other English name: Sticky Cockle.

Other Latin name: Melandrium noctiflorum Fries.

Introduced from Europe. Annual and winter annual. Erect, 1 to 3 feet high, somewhat branching; whole plant covered with soft, spreading, glandular hairs. Lower leaves ovate, narrowed at the base; stem-leaves lance-shaped. Flowers few, erect, in a branching cyme, nearly an inch across, pinkish inside, yellowish white outside, opening at night, corolla divisions deeply divided; fruit capsule clongate ovoid, with 6 teeth at the top; calyx at first cylindrical, afterwards broadly ovoid, with 5 long teeth at the apex, and marked with 10 prominent green nerves.

The seed (Plate 73, fig. 21) is about the same size as that of Bladder Campion, grayish-brown, with a tiny black tip to each tubercle. These tubercles are not in regular concentric rows, but are evenly spread and cover the whole seed without regular arrangement.

Time of flowering: June to autumn; seed ripening in July and till frost.

Propagation: By seeds only.

Occurrence: Throughout the Dominion. Abundant in the East, particularly in thin clover fields; rather rare in the West, where it is of comparatively recent introduction.

Injury: A rank grower and heavy seeder; particularly troublesome in clover fields. On account of its pungent flavour and woody texture, it is objectionable to live stock, whether in pastures or cured fodder, and when at all prevalent in hay a considerable waste results. The seed is a common impurity in clover and grass seeds; alsike seed frequently contains large quantities of it.

Remedy: Farmers who sow clover and grass seed free from the seeds of Catchfly will not long have trouble with it on lands worked under a short rotation of crops. The appearance of this cockle in alsike fields is largely due to its being sown with the clover seeds. For alsike seed crop, only clean land and the purest obtainable seed should be used. Hand-pull before cut- 


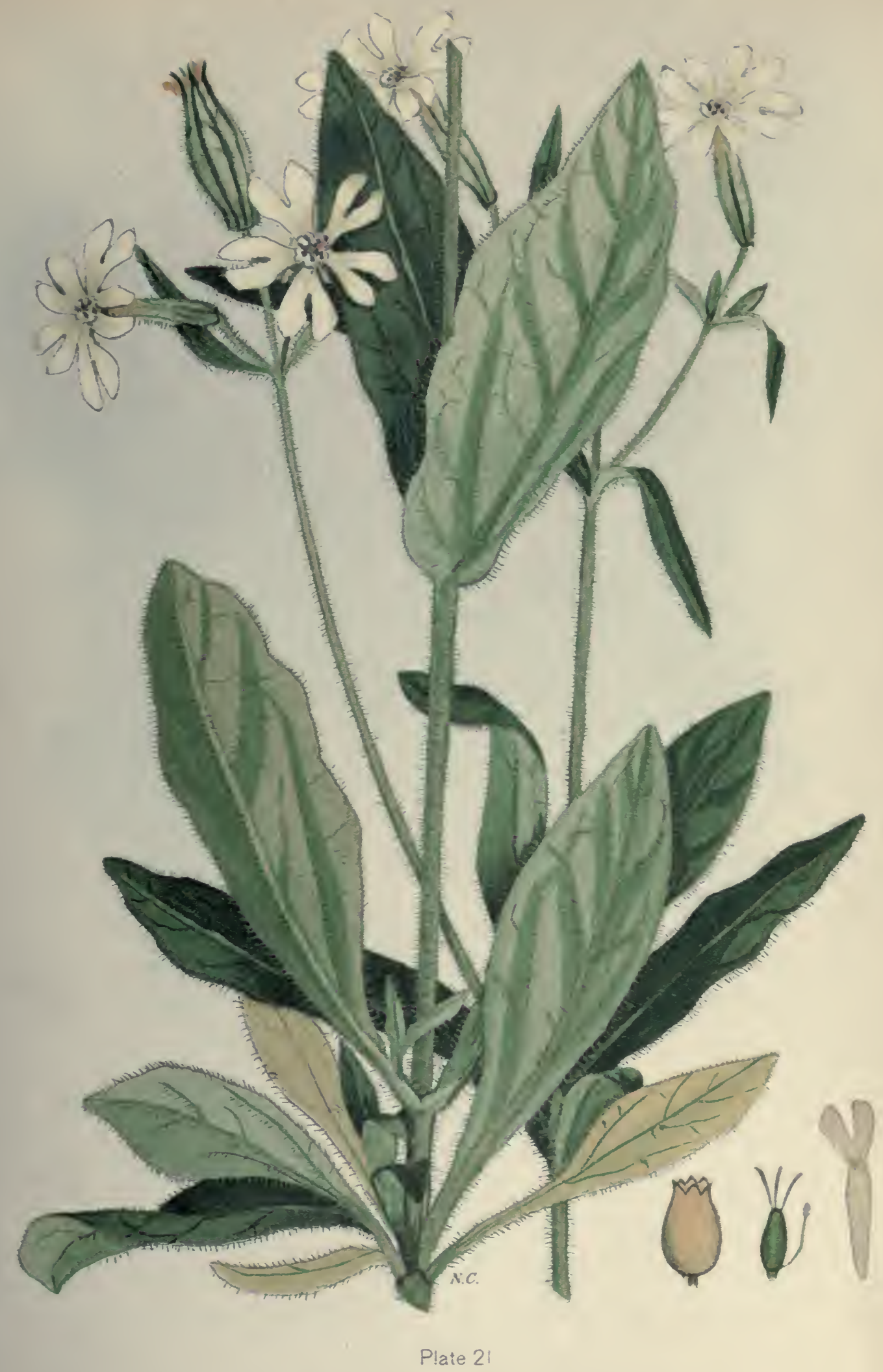

NIGHT-FLOWERING CATCHFLY OR STICKY COCKLE

(Silene noctiflora 

ting clover seed crops; the increased value of the seed will pay for the labour. Fields of alsike so badly infested as to render hand-pulling impracticable should be cut for hay and the land put under a system of cultivation calculated to clean it of the weed seeds. A rotation of crops exclusive of alsike seed should be adopted for six or eight years. Grass or clover seeds containing Catchfly should be thoroughly cleaned in mills equipped with screens specially designed to remove this impurity, and should not be used on land that may later be required for the production of alsike seed.

ALLIED SPECIES: The genus Silene embraces a tribe of herbaceous plants represented by more than three hundred species, relatively few of them are cultivated for decorative purposes, the greater number being useless wayside weeds.

Conical Catchfly (Silene conica L.) is occasionally met in southern Ontario in fields and waste places. It is a small plant, with small pink or purple flowers and a cone-shaped fruit capsule. The seed is about $2 / 3$ the size of that of Night-flowering Catchfly.

Sleepy Catchfly (Silene antirrhina L.), probably introduced with imported clover seed, is quite widely distributed. It has a slender stem which frequently shows purple colouring, about 2 feet in height, with narrow leaves. The flowers are quite small and pinkish-white. The seed is of the same form as that of Night-flowering Catchfly, about half the size and darker in colour; it is difficult to separate from timothy seed, and is occasionally present in commercial samples of various kinds of grass and clover seeds.

Garden Catchfly (Silene Armeria L.) : is frequently found growing in fields near old gardens from which it has escaped. It is an annual, with pink and white flowers, and seldom gives serious trouble.

Small-flowered Catchfly (Silene gallica L.) is quite common in the eastern provinces and on the Pacific coast. It is about 15 inches high, branched; flowers small and white. The seed is similar to that of Sleepy Catchfly in size and colour and is noticeably depressed on each side adjacent to the scar. 
BLADDER CAMPION (Silene latifolia (Mill.) Britten \& Rendle).

Other English names: Cow-bell, White Bottle, Rattle Weed.

Other Latin names: Cucubalus Behen L.; Silene Cucubalus Wibel.; Silene vulgaris (Moench) Garcke; Silene inflata Smith; Behen vulgaris Moench.

Introduced from Europe. Perennial, with deep running rootstocks, which send up many barren shoots and branched flowering stems, erect or nearly so. The whole plant is pale green and in the common form perfectly smooth. Stems 1 foot to 18 inches high, forming large tufts. Leaves ovate-lanceshaped, in pairs, meeting round the stems. Flowers white, nearly an inch across, drooping, the corolla divisions deeply divided. Calyx much inflated, pale green veined with light purple, 5-toothed at the contracted apex. Capsule globularovoid, included in the calyx, opening by 5 short backward curved teeth.

The seed (Plate 73, fig. 22) is round-kidney-shaped, about $1 / 20$ of an inch in diameter, covered with concentric rows of small, cone-shaped tubercles. The seeds of this species and of Night-flowering Catchfly and White Cockle are so similar that they can be separated only by an expert. On plates 72 and 73 , the average characteristics of the seeds of each species are represented. Note specially the arrangement of the tubercles.

Time of flowering: May to July; seeds ripe in July.

Propagation: By seeds and rootstocks.

Occurrence: By roadsides, on railway banks, in pastures, hay and grass fields, throughout the eastern provinces.

Injury: This weed has become widely distributed during recent years and has proven to be the most troublesome of the cockles. Wherever established, it crowds out cultivated plants and is difficult to suppress by cultivation. It seeds freely and the seeds are hard to separate from red clover seed. 


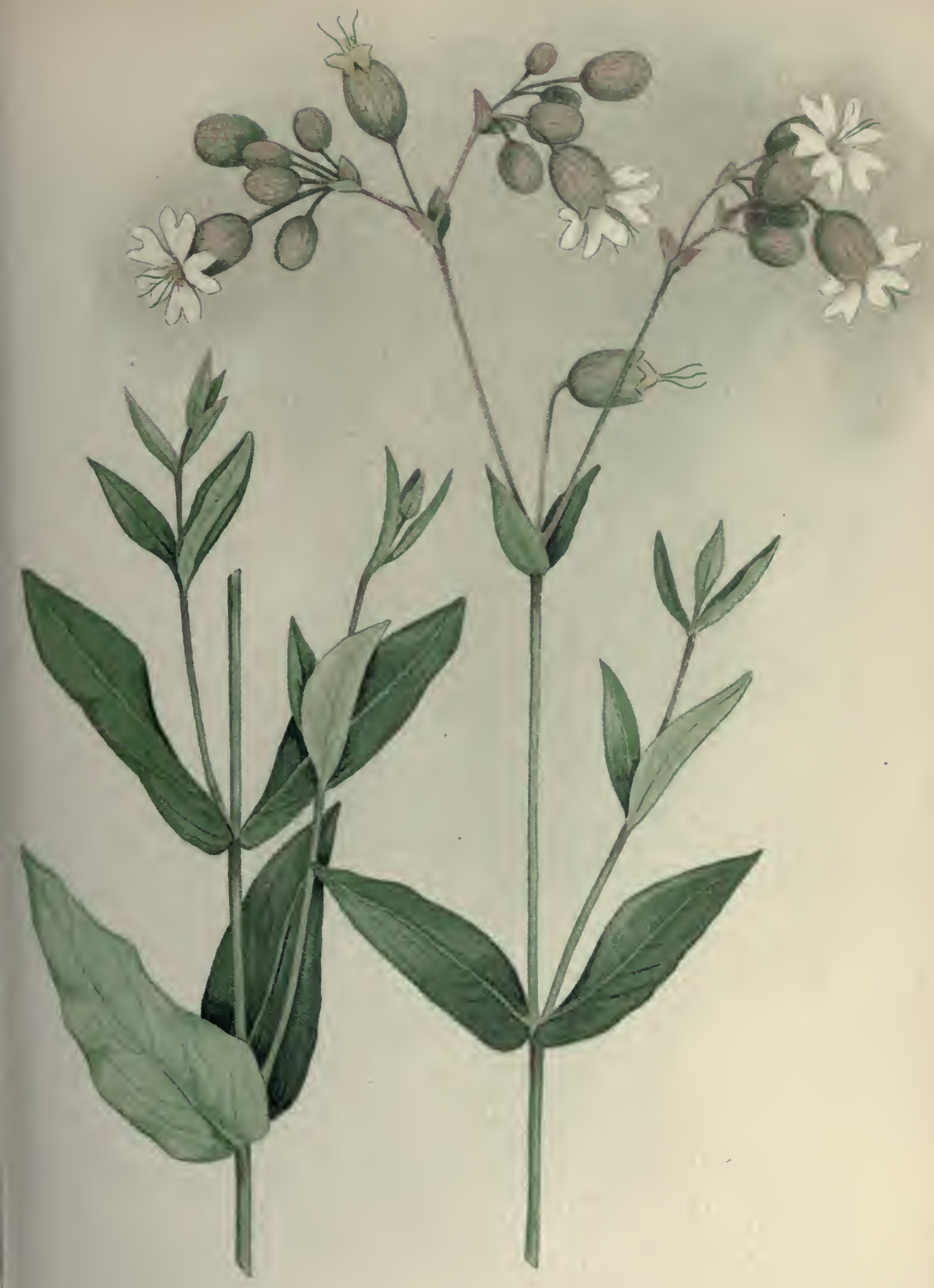

Plate 22

BLADDER CAMPION

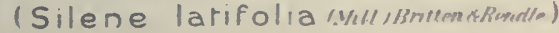



Remedy: A clover crop in which this cockle is prevalent should be cut early for hay, then deeply plowed and thoroughly fallowed during the balance of the season, preparatory to a hoed crop. Clover seed should not be sown on land polluted with this weed. Seeding to clovers and grasses gives it an opportunity to establish itself. A rotation of crops calculated to suppress it should allow for deep and thorough cultivation each spring before seeding and again as soon as the crop is removed, as could be given by sowing peas, vetches or other crops to cut green for fodder, followed by a hoed crop, and the third year cereal grains. On account of the occurrence of the seed in commercial grass and clover, this weed is almost certain to be introduced on farms from time to time, and it will require close scrutiny of clover crops to detect occasional plants. When found, these can be destroyed by applying a handful of salt to the root after cutting in hot dry weather.

For truly from all sorts of Herbes and Flowers we may draw matter at all times not only to magnifie the Creator that hath given them such diversities of formes, sents and colours, that the most cunning Worke-man can imitate, and such virtues and properties, that although wee know many, yet many more lye hidden and unknowne, but many good instructions also to ourselves.

-Parkinson, 1629.

To thy corn fields thou dost go, Which, though well soiled, yet thou dost know That the best compost for the lands

Is the wise master's feet and hands.

-Herrick, 1648.

Some Herbs are but Annual, and die, Root and all, once a year; as Borrage, Lettuce, Cucumbers, Musk-Melons, Basil, Tobacco, Mustard seed, and all kinds of Corn; some continue many years, as Hyssope, Germander, Lavender, Fennel, \&c. The cause of the Dying is double; the first is, the tenderness and Weakness of the Seed, which maketh the period in a small time; as it is in Borrage, Lettuce, Cucumber, Corn, \&c. And therefore none of these are hot. The other cause is, for that some Herbs can worse endure cold, as Basil, Tobacco, Mustard-seed; and these have all much heat. 


\section{COW COCKLE (Saponaria Vaccaria L.).}

Other English names: Cowherb, China Cockle.

Other Latin names: Vaccaria Vaccaria (L.) Britton; Vaccaria vulgaris Host.

Introduced from southern Europe. Annual. Stem simple, branching above or much branched from the base, 1 to $2 \frac{1}{2}$ feet. The whole plant is smooth, succulent and of a grayish-green appearance, like the leaves of a cabbage. Leaves ovate-lanceshaped, clasping the stem. Flowers pale rose-pink, $1 / 2$ inch across, in loose corymb-like cymes. Calyx ovate, 5-ribbed and much inflated, winged and angled in fruit. The smooth roundish fruit capsules contain about 20 seeds each.

The seed (Plate 73, fig. 23), is round, hard, dull black, about $1 / 12$ inch in diameter, and is often confounded with the seeds of wild vetches. It can be distinguished from vetch seeds of a similar size by its minutely roughened surface, or by cutting it open after soaking, when the germ, which lies in a circle around the seed just beneath the seed-coat, will be seen. It in no way resembles the inside of a vetch or pea, which, when the seed-coat is removed after soaking, can be easily separated into similar halves.

Time of flowering: July; seeds ripe in August.

Propagation: By seeds only.

Occurrence: As a troublesome weed, only in the Prairie Provinces.

Injury: A pestiferous weed in grain crops in the Prairie Provinces. The succulent plants rob the crop of moisture. Being a vigorous grower, the large branched top occupies much space and crowds out the grain. The seeds are a common impurity in commercial wheat and are almost as objectionable to the miller and baker as are those of Purple Cockle. 


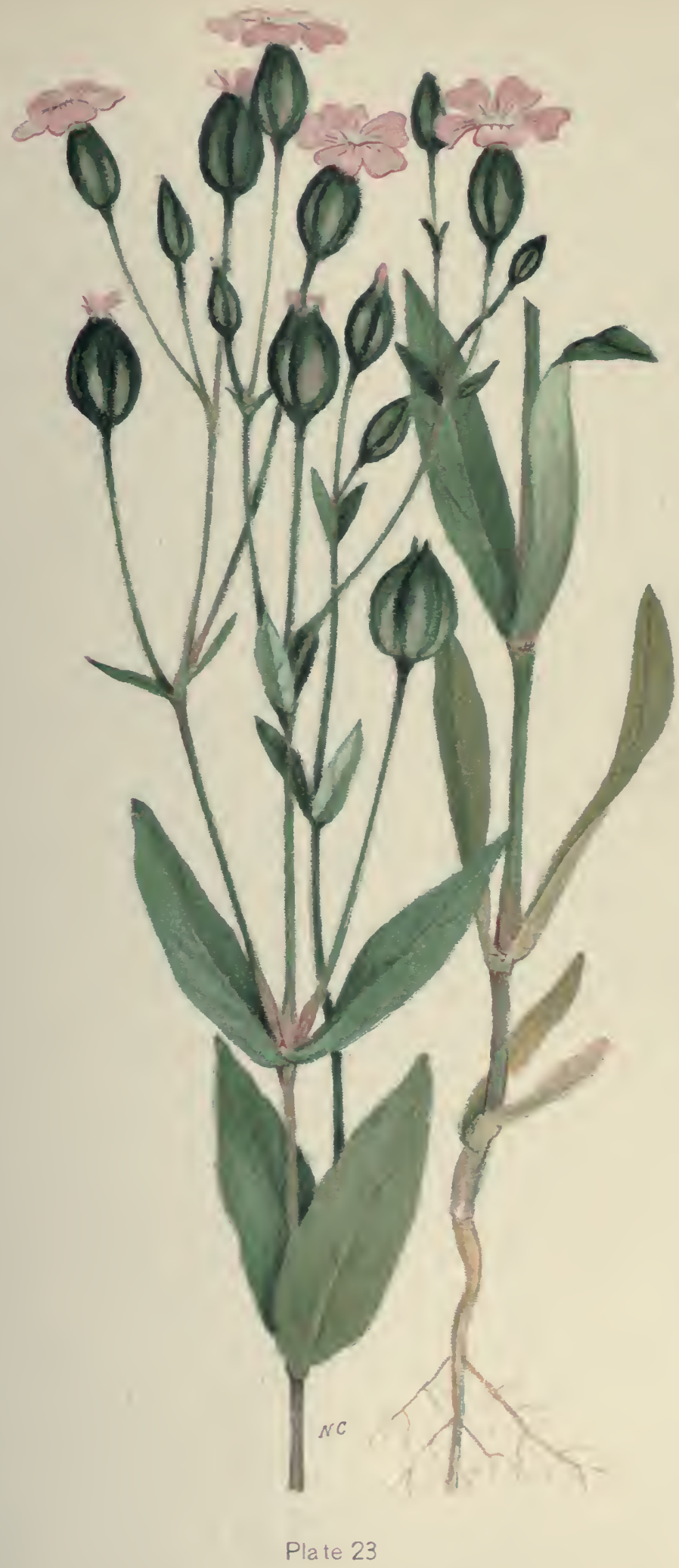

COW COCKLE OR COW - HERB

(Saponaria Vaccarıa L.) 

Remedy: Sow clean seed. Prevention is the best and least expensive method of fighting it. It is a large showy plant and when not present in excessive numbers can be easily hand-pulled. The seed will not retain its vitality long; when land is seeded to timothy or western rye grass and left for a few years, the supply of vital seeds in the soil will be greatly reduced, if not entirely exhausted. Where land is badly infested with Cow Cockle, a thorough summer-fallow, as outlined for Purple Cockle, is the most effective method of exterminating it. Harrowing grain crops just before the grain emerges from the ground, and again when it is three inches high, will kill any seedling weeds.

ALLIED SPECIES: Bouncing Bet (Saponaria officinalis L.) is a showy plant about 2 feet in height. Flowers light pink, in compact panicle-like cymes. A common perennial weed along roadsides and waste places; varieties of this species are cultivated in gardens. Sometimes called Soapwort because the roots can be used for washing instead of soap.

\section{THE PURSLANE FAMILY (Portulacaceae).}

This small family of plants comprises about twenty species, all low, fleshy herbs, with mostly alternate thick leaves. The seeds are borne in great numbers in cone-shaped capsules. The flowers are sensitive to sunlight and close at night or when completely shaded. Rose Moss (Portulaca grandiflora Hook), of which there are several improved varieties, is cultivated for decorative purposes. Purslane is a typical and well-known representative of this family and the only one that gives serious trouble.

Thry fallow betime, for destroying of weed, least thistle and docke, fal a blooming and seed: Such season may chance, it shall stand thee upon; to till it again yer summer be gon. 


\section{PURSLANE (Portulaca oleracea L.)}

Other English names: Pusley, Wild Portulaca.

Introduced from Europe. Annual. A fleshy, prostrate, perfectly smooth plant, freely branching from a single central root, with fleshy reddish stems and dark green, alternate, obovate or wedge-shaped leaves mainly clustered at the ends of the branches. Flowers stalkless, solitary, about $1 / 4$ inch across, yellow, opening only on sunny mornings. Fruit capsule membranous, many-seeded, the top coming off as the lid of a box.

The seed (Plate 73, fig. 24), black, roughened but shining, about $1 / 40$ of an inch in diameter, narrowly kidney-shaped, much as in the Pink family, and, like the seeds of most of the members of that family, with a curved germ running around the outside of the seed.

Time of flowering: July till frost; seeds ripening during the greater part of that time.

Propagation: By seeds. The fleshy leaves and stems give it such vitality that flowering plants hoed out and left on the ground will continue ripening seeds for weeks.

Occurrence: In rich land, particularly in gardens. Most abundant in the eastern provinces, constantly being introduced into new localities with seeds. It is now found in gardens in most parts of Canada.

Injury: The noxious nature of this persistent pest is due to its ability to produce large numbers of seeds that retain their vitality for several years. The seeds do not germinate until the soil has become quite warm, and they are able to produce seedling plants only when brought quite close to the surface. It is especially troublesome late in the season in gardens and hoed crops. When young and tender the plants are sometimes used as a pot herb and are of value as green food for pigs.

Remedy: Bare summer-fallow with frequent cultivation. Clean cultivation of hoel erops; the late general cultivation 
should be unusually shallow to aroid bringing the seeds to the surface. Frequent attention with the hoe is needed after general cultivation has ceased. Seeds that have formed will develop and mature on the fleshy stems of the plant after it has been cut; it is therefore necessary to remove and destroy the plants that have formed seeds. A revolving pea rake may be used to gather the plants from stubble lands. The plants so gathered may be used as green food for pigs, but care should be taken that the seeds are not returned to the fields in the manure. Constant raking, to raise the prostrate stems, followed by close cutting, is recommended for lawns in which this pest gives trouble. A three-year rotation, including summer-fallow directly after the removal of a crop of early clover, followed by hoed crop and again by cereal grain for the third year, will keep it in check. If given access to corn and potato fields, sheep will feed on late plants, and if their pasture is short, will prevent many of them from seeding.

\section{THE BUTTERCUP FAMILY (Ranunculaceae).}

A hardy family of plants, generally distributed in moist places in temperate and cold climates. Mostly perennials. The Ramunculaceae are herbaceous or woody plants, generally containing a colourless, acrid juice. The leaves are often compound or dissected, with the leaf-stalks swollen at the base. The fruits are variable: they may be berries, pods or dry seed-like fruits. This family contains a few weeds of secondary importance as well as the more virulent Larkspurs (Delphinium) and Monkshoods (Aconitum) of the western plains. Crocus Anemone (Anemone patens L., var. Wolfgangania (Bess.) Koch.) has caused losses in flocks of sheep. Owing to its early flowering and its succulence, the hairy stems are eaten and the copious hairs, remaining undigested, form balls in the stomachs of the sheep. White or Pennsylvanian Anemone (Anemone canadensis L.) sometimes increases so much in low pastures that it crowds out the grasses and necessitates breaking up the sod. The seed (Plate 73, fig. 26) is sometimes found with the seeds of grasses. 
TALL BUTTERCUP (Ranunculus acris L.)

Other English names: Tall Crowfoot, Meadow Buttercup.

Introduced from Europe. Perennial, with fibrous roots. Stem erect, generally hairy. The leaves in 3 divisions, each division stalkless, 3-cleft or parted, with deeply lobed segments. Flowers yellow. The dry seed-like fruits are in heads.

The seed (Plate 73 , fig. 25) is about $1 / 8$ of an inch in diameter, flat, nearly round in outline but unsymmetrical with a somewhat wing-like margin; both the tip and the scar ends are pointed and very prominent, the former generally hooked. The colour varies from greenish-brown to nearly black; dull from the roughened surface.

Time of flowering: June to August; seed ripe by July.

Propagation: By seeds.

Occurrence: Throughout Canada, especially in moist lands.

Injury: A noxious weed with a poisonous, acrid, blistering juice; common in pastures and meadows. Farm stock will not feed within range of the leaves. When cured in hay it appears to be less objectionable. It does not give trouble in well-drained soils cultivated under a systematic short rotation of crops, but it is difficult to suppress on lands left to permanent pasture or hay. The seeds are commonly found in grass and clover seed.

Remedy: When possible bring land under cultivation and good drainage. Summer or autumn fallowing, when the land is dry, is efficacious. Postpone seeding to grass until the weed is completely suppressed. Pasture lands that cannot be cultivated should be gone over two or three times each year and the plant closely cut, first when in early bloom and again about July or August. If continued for two or three years, this practice will usually suppress it.

ALLIED SPECIES: Several allied speeies are prevalent in many districts as weeds of secondary importance. 


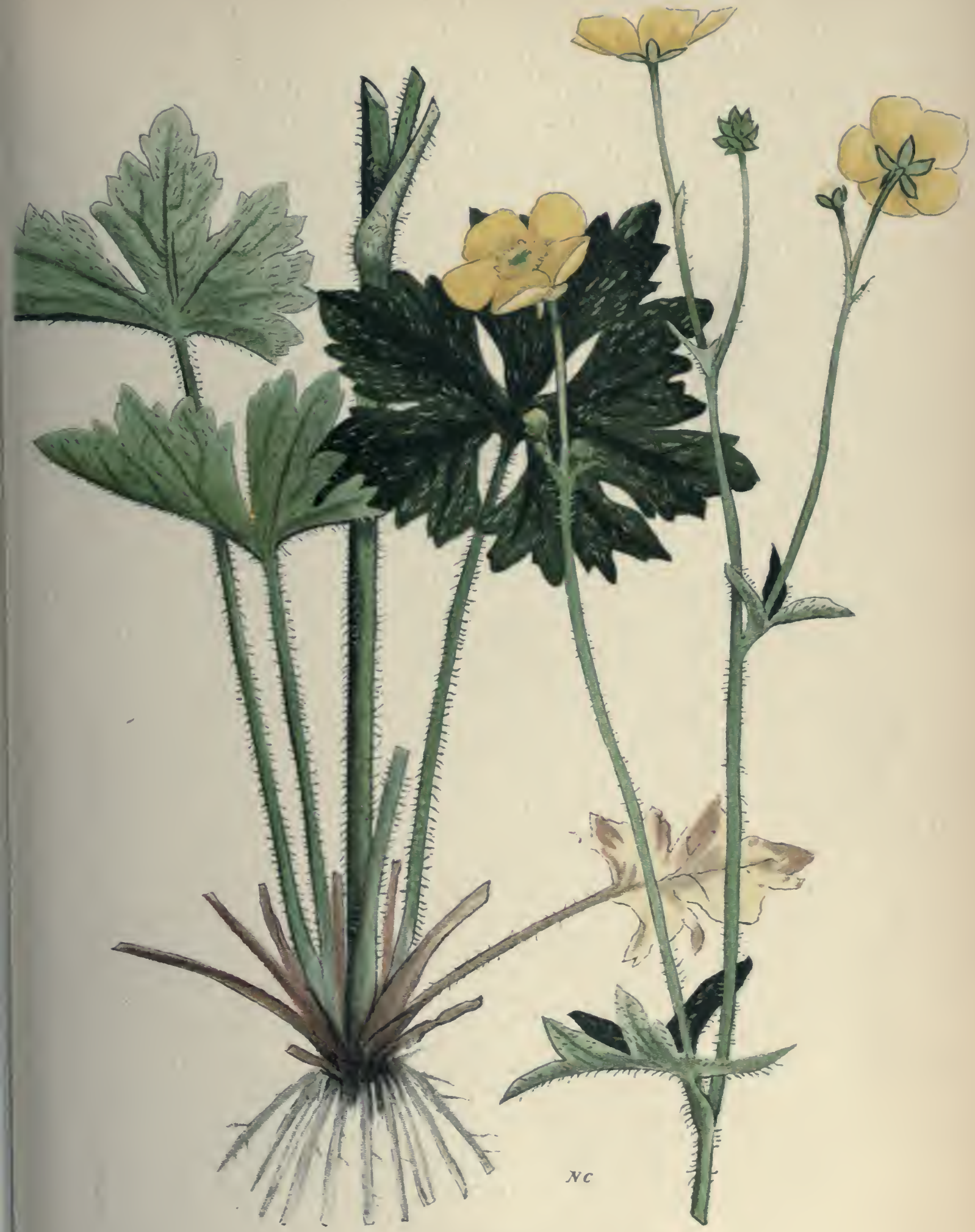

Plate 25

TALL BUTTERCUP OR CROWFOOT (Ranunculus acris $/$.) 

Cursed Buttercup or Ditch Crowfoot (Ranunculus sceleratus L.) is abundant along ditches, creeks and ponds; occasionally found in wet pastures. It may be distinguished from Small-flowered Buttercup by its thick hollow stems.

Small-flowered Buttercup (Ranunculus abortivus L.) is common in old pastures and open woods, less frequent in meadows and cultivated fields. Its lower leaves are smooth, and round or kidney-shaped.

\section{THE FUMITORY FAMILY (Fumariaceae).}

This family is represented by Golden Fumitory (Corydalis aurea Willd.), an occasional weed in the wheat fields of Manitoba. The plant sometimes appears in low lands and restricted areas in such numbers as to crowd out grain crops sown on stubble. It is a succulent biennial, smooth, hairless and branching, with finely dissected leaves and golden-yellow flowers. Spring or fall plowing or discing stubble lands before sowing will eradicate it.

The seeds (Plate 73 , fig. 27) are about $1 / 12$ of an inch in diameter, shining black, rounded-kidney-shaped, borne in manyseeded, somewhat knotty, curved pods which split down one side to shed the seeds. Sometimes found in commercial seeds.

\section{THE MUSTARD FAMILY (Cruciferae).}

Few families of plants are of such great economic importance as the Mustard family, not only from the large number of troublesome weeds it contains, but also from the fact that not a single unwholesome plant is found in it. Many species form well-known and excellent articles of food, as the cabbage, turnip, radish, watercress, etc. Some of our worst weeds, however, most of which have been introduced into Canada, belong to this family. Their characteristics are easily recognized. Many of the Cruciferae have in their roots, stems or seeds, odours or flavours which help 
to identify them. The leaves and stems of many bear small, star-shaped hairs. The flowers are regular, composed of four free calyx divisions and four free corolla divisions, arranged in two opposite pairs and forming a cross-shaped flower, from which the whole family takes its name, Cruciferae. The flowers are borne on footstalks and clustered at the tips of branches which gradually elongate, forming long, upright racemes, often with fully formed and even ripe pods below, before the topmost flowers have opened. When ripe the seed pods, which are of various shapes, usually consist of two outside walls separated by a thin white partition, to the sides of which the seeds are attached.

The seeds as a rule are small and numerous. Their surface is usually rather dull and more or less granular. Many, when placed in water, develop a coat of mucilage, by which, when dry, they remain attached to passing objects or adjacent surfaces. This is an important factor in their distribution. The quantity of mueilage developed varies; on some seeds it remains after drying as a covering of hair-like points or threads. The seedcoat is generally thin and close-fitting, the position of the germ showing plainly through it.

\section{WOOD WHITLOW GRASS (Draba nemorosa L.).}

Other English name: Yellow Whitlow Grass.

Native. Annual and winter annual. Slightly downy. Stem low, branching below, leafy to the elongated raceme. Leaves stalkless, oblong-ovate or lance-shaped, somewhat toothed. Flowers whitish yellow. Pods elliptical-oblong, half the length of the footstalks, which are almost horizontal at maturity.

The seed (Plate 73, fig. 28) is small, 1/16 of an inch long, egg-shaped, flattened, redclish brown, with a rough surface.

Time of flowering: Early June; seeds ripe by end of June.

Propagation: By seeds. 


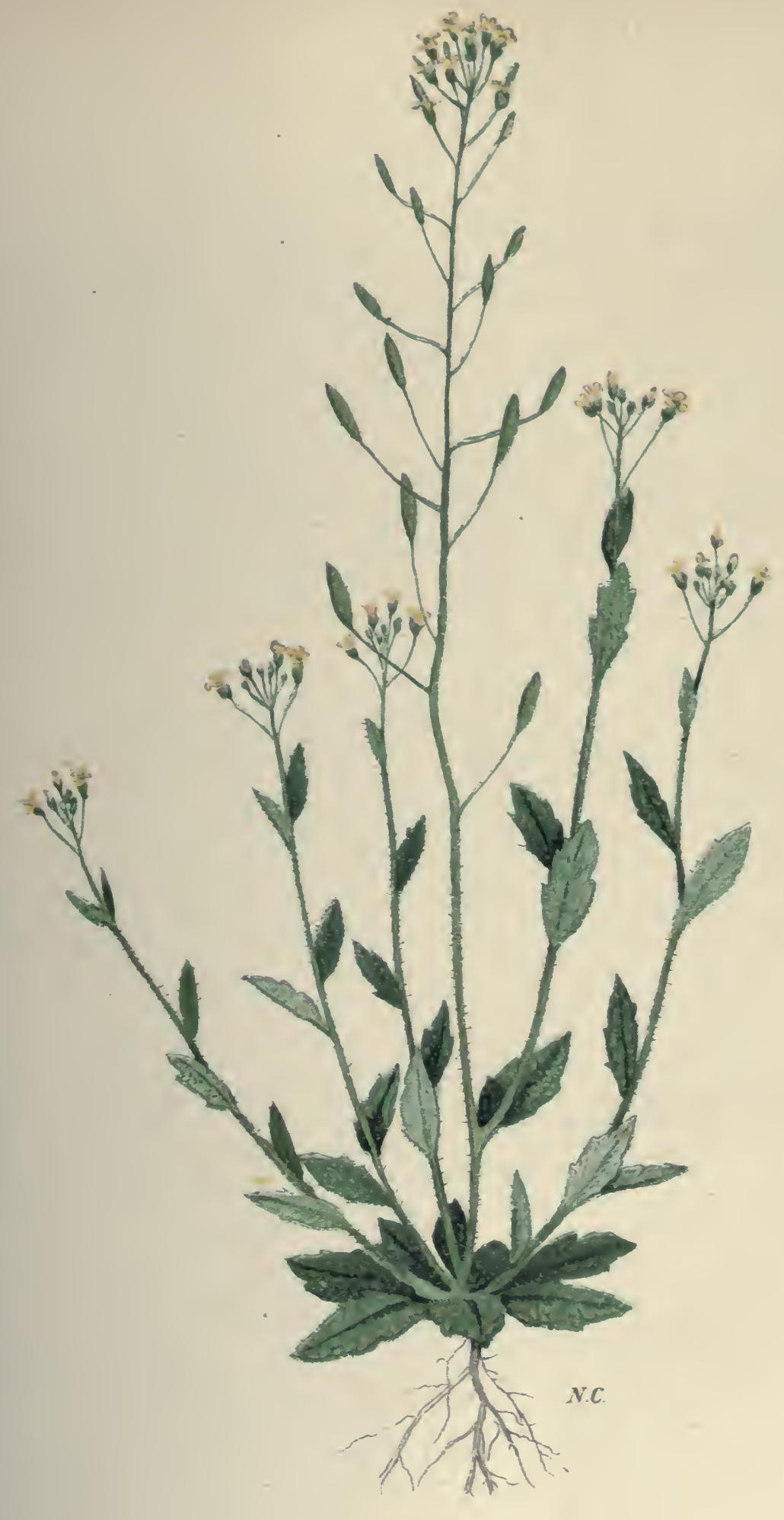

Plate 26

WOOD WHITLOW GRASS

(Draba nemorosa /.) 

Occurrence: Abundant in parts of western Ontario and northward. Found occasionally in the Prairie Provinces. The Whitlow Grasses include a large number of species widely distributed throughout Canada. Macoun's catalogue includes twenty-five species and varieties. They are mostly weeds of secondary importance. Some varieties are cultivated for decorative purposes.

Injury: Most frequent in waste places, neglected fields, old meadows, lawns, and along roadsides. It is not a serious pest, but the genus is of importance because of the large number of species which it contains and their wide distribution.

Remedy: The whitlow grasses do not long continue in evidence on farms worked under a short rotation of crops. Summer-fallows should be plowed before the seed is formed. Continued raking and close cutting will suppress them on lawns. Grass lands over-run with them may be devoted to sheep pasture.

ALLIED SPECIES: Vernal Whitlow Grass (Draba verna L.) and Carolina Whitlow Grass (Draba caroliniana Walt.) and varicties are prevalent in many localities in the eastern provinces.

Now 'tis the spring, and weeds are shallow-rooted; Suffer them now, and they'll o'ergrow the garden, And choke the herbs for want of husbandry.

-Shakespeare, 2 Henry VI, Act III, sc. i, 1592.

"That there are many seeds which lie long in the ground without any visible signs "of germination is not to be disputed." And I see no impossibility against their having lain so from the deluge, if not from the creation of the world (I mean such of them as lie deep in the earth, and have never been exposed to the sun, air, \&c.). 


\section{STINKWEED (Thlaspi arvense L.)}

Other English names: Penny Cress, French Weed, Mithridate Mustard.

Introduced from Europe. Annual and winter annual. Stem erect, simple or branching. Whole plant bright green and quite smooth. Root leaves borne on footstalks; stem leaves spear-shaped, coarsely toothed, clasping the stem with the arrowshaped base. Flowers clear white, $1 / 8$ of an inch across; at first in a small, flat cluster at the top of the leafy stem. Racemes elongated in fruit. Pods flat, $3 / 4$ of an inch across, containing from 8 to 16 seeds, on slender, upward-curved footstalks, pale green and winged, notched at the top. Just before the seeds ripen the pods turn a characteristic greenish-orange shade, easily noticed when this weed is growing among crops.

The seed (Plate 73, fig. 29) is about 1/12 of an inch across, a little longer than broad, deep purplish-brown, unsymmetrically oval in outline, flattened, with rounded edges. The flattened surface has 5 or 6 loop-like lines, which start at the basal scar or notch and run concentrically around a central groove. No mucilage develops on these seeds when soaked in water.

Time of flowering: Plants in bloom when winter sets in freeze up, but as soon as they thaw out in spring they continue to grow and mature their seeds without the slightest injury, and continue ripening until frost. The seeds of these early plants are ripe early in July. Plants which grow from seed in the spring are not ripe until some weeks later. After the middle of June they are too far advanced to be plowed down.

Propagation: By seeds.

Occurrence: Stinkweed is now found in every province in Canada, but nowhere else is it such a terrible pest as in the Prairie Provinces, where it was introduced with the first settlers. 


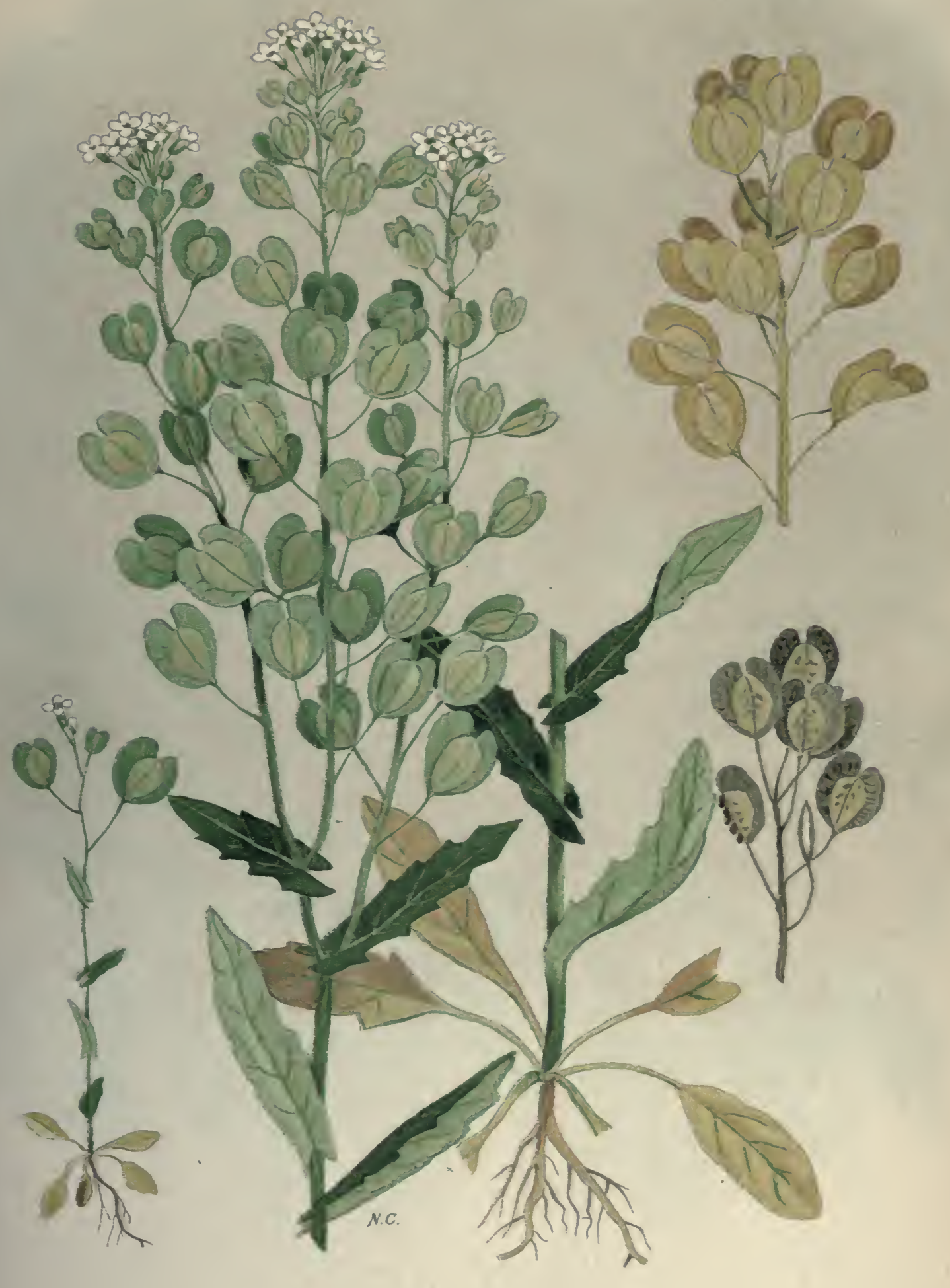

Plate 27

STINKWEED OR FIELD PENNYCRESS

(Thlaspi arvense L.) 

Injury: A most persistent and aggressive enemy of the western farmer. This pest is found in the greatest abundance in the rich lands of the Red River Valley, where it flourishes with remarkable vigour and where it is difficult to control it on account of the distribution of its seeds by spring floods. When once established the soil soon becomes polluted with it, and on prairie lands it crowds out cereal grains almost to the limit of profitable production.

Remedy: Hand-pulling and burning is probably the best way to stamp out Stinkweed in new localitics and in small quantities, but when it is thoroughly established more drastic measures must be adopted. They are all based on some method by which the seeds are covered up to make them germinate; then the young plants are destroyed with the harrow, cultivator or plow before seeds ripen. The land should be cultivated as soon as a fresh growth of the weed develops. Great care must be taken not to plow down any full-sized pods, even though they may be green, as it has been proven that in the dry climate of the West such seeds can ripen beneath the soil. On land to be summer-fallowed, if there is a heavy growth of this weed with fully formed seed pods, the plants should be mowed down, removed from the field and piled on a piece of hard land, where, after drying, they can be burnt. T. N. Willing says truly: "Close attention should be given to any portion of a farm where Stinkweed has been noticed and careful persistent work will be required to eradicate it; but it will pay well to drop all other work and fight this weed when it is first noticed."

The most important measure to clear the land of Stinkweed is harrowing the growing crop to kill the seedlings. The harrowing should commence before the crop emerges from the ground, be repeated when the grain is about three inches high, and repeated again in bad cases when the grain is five or six inches high. Experiments in the Red River Valley have shown this method to be most effective; and clean fields, giving crops of forty bushels per acre, may there be seen, close to others bearing not more than from ten to twelve bushels per acre, 
the difference being entirely due to the presence of Stinkweed in the one case and to its having been harrowed out in the other.

Running the disc or harrow over stubble immediately after the binder, so as to start into growth the seeds near the surface, gives good results. The following spring, harrow or eultivate these plants down as soon as a fresh growth starts, then plow and harrow at once. This land may be sown late to a green feed erop, or it may be kept under a clean fallow for the whole season if the land can be spared. The following spring any plants that appear should be cultivated before sowing the crop. An excellent plan, which will enable the farmer to take a rest in this fight, is to seed down with timothy or western rye grass. Such fields require mowing occasionally during the season to prevent seeds ripening. The grass will choke out even the Stinkweed after the first year. When the sod is plowed up again some seeds may still be vital, but these can be dealt with as before.

\section{PEPPERGRASS (Lepidium apelalum IVilld.)}

\section{Other Latin name: Lepidium intermedium Gray.}

Native. Annual and winter annual. Stems erect, profusely branching above, 6 inches to 2 feet high, somewhat hoary with short appressed hairs. Autumn plants produce a rosette of dark-green, deeply indented leaves, much like some specimens of Shepherd's Purse but more succulent. Stem-leaves with a few coarse teeth, narrowed at the base. The many nearly erect and spreading branches give this plant, when in seed, the appearance of a miniature tree, the numerous, small, nearly round, flat pods taking the place of leaves; the real leaves fall away when the seeds begin to ripen. The flowers are minute; the seed-pods about $1 / 10$ of an inch wide, heart-shaped, slightly longer than wide, notched at the top and at maturity separate into halves. 


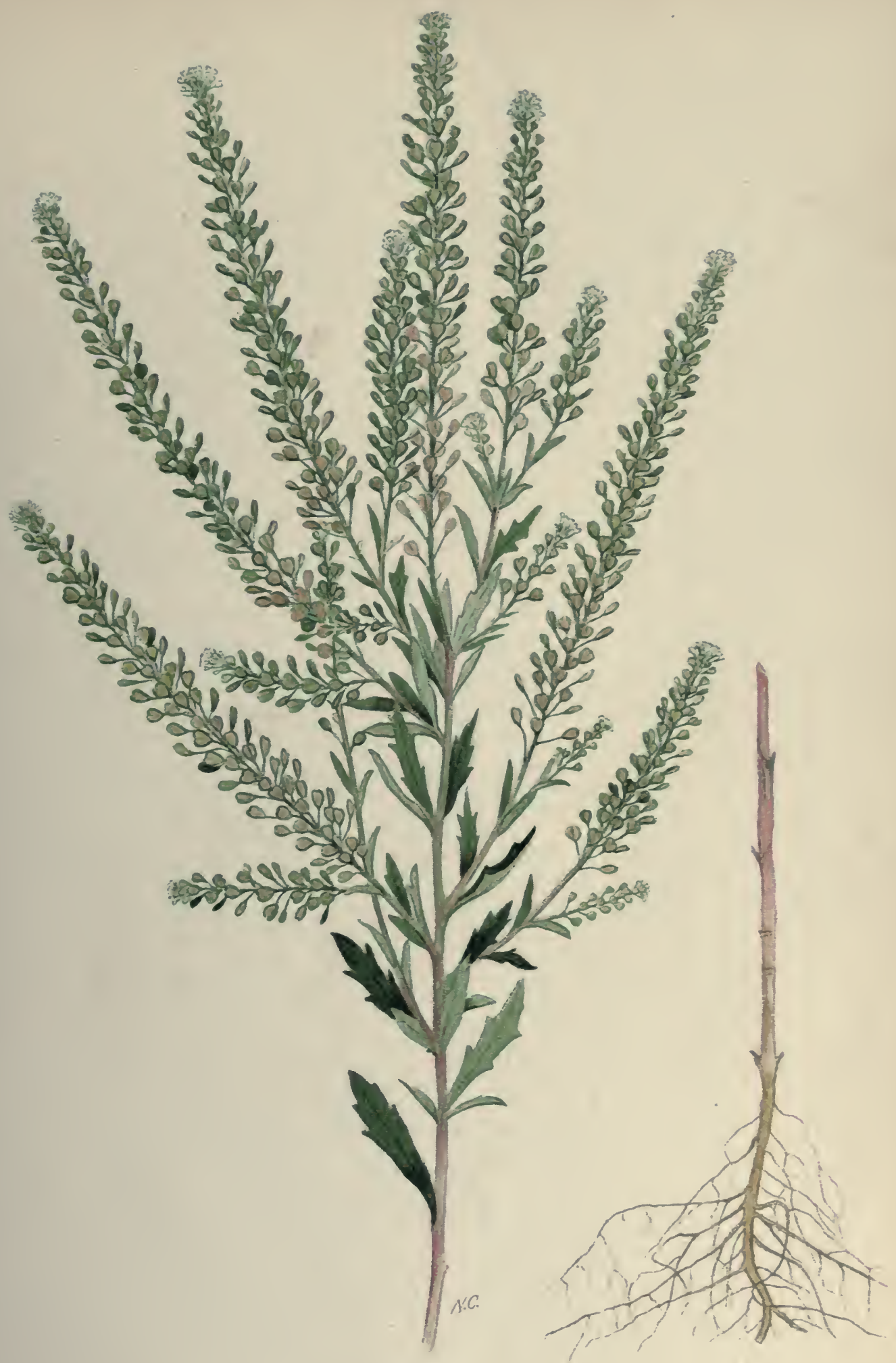

Plate 28 


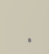

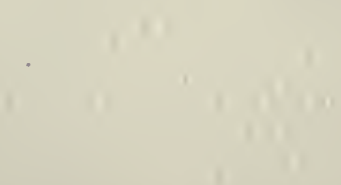


The seed (Plate 73 , fig. 30 ) is about $1 / 16$ of an inch in length, bright reddish-yellow, egg-shaped in outline, much flattened, blunt on the straight side and very thin or slightly winged on the rounded side; both sides show a rather deep groove in the middle. When moistened the seeds develop a large amount of mucilage. Although there are only two seeds in a pod, each plant produces thousands of seeds.

Time of flowering: June, July; seed ripe on early plants by the end of June.

Propagation: By seeds.

Occurrence: Widely distributed throughout the Dominion. Most abundant on light sandy soils in eastern Canada.

Injury: In the West it crowds out grain crops grown on stubble, particularly on light land and in a wet spring. This is from the autumn plants, which get a start before the grain and choke it out with their thick, vigorous growth. It gives trouble in clover fields and new meadows where the crop is winter killed. The seed is a frequent impurity in grass and clover seeds.

Remedy: Only the autumn plants which live through the winter give trouble in grain. Thorough surface cultivation in the spring, with the plow, disc or broad-shared cultivator, is efficacious. Immature seeds may ripen in the pods when plowed down. Badly infested fields in the eastern provinces should be diseed or plowed directly after harvest, cultivated from time to time until winter, and again until late in June, when they may be planted, or sown with a late fodder crop.

ALLIED SPECIES: Field Peppergrass or Cow Cress (Lepidium campestre (L.) R. Br.). A biennial yet rare in Canada, occurring in the clover-growing districts of Ontario. The plant grows with two or three stems from the same root. These are branched above, forming corymbs, with a few nearly erect branches. The lower leaves are oblong and toothless; those of the stem are spear-shaped with blunt ends, a few have large, shallow 
teeth and an arrow-shaped base. The thick pods are broadly ovate, boat-shaped, being rounded below and hollowed out above. Each pod contains two seeds.

The seed is $1 / 12$ of an inch long, egg-shaped, but pointed at the scar end. The surface is finely roughened and dull, with a mealy appearance. Two grooves, often filled with mucilage, extend from the sharp basal end almost to the other end of the seed.

SHEPHERD'S PURSE (Capsella Bursa-pastoris L.).

Other Latin names: Bursa pastoris Weber; Thlaspi Bursapastoris L.

Introduced from Europe. Annual and winter annual. Few plants are so variable in size and appearance. It may be bright green and nearly smooth, or gray from very short appressed hairs. A seed-bearing plant may be a dwarf, little more than an inch or two high, or a vigorous, branching plant, three feet high, with many pods. There may be at the base a vigorous rosette of leaves, or none at all. The leaves may be deeply cut, pinnatifid, or without any teeth or division. The stem-leaves are for the most part arrow-shaped, with two sharp, ear-like projections, one on each side of the stem. The flowers are small and white. The only part of the plant which seems to be constant is the seed-pod, which is flat, triangular in shape, $1 / 4$ of an inch long, wedge-shaped at the base, notched at the top, with the outer angles rounded. Each pod contains about 20 seeds.

The seed (Plate 73 , fig. 31 ) is small, $1 / 24$ of an inch long, oblong, reddish brown, the surface dull and punctured. When put in water it develops a large amount of mucilage and a covering of rather long but very fine, transparent hairs. 


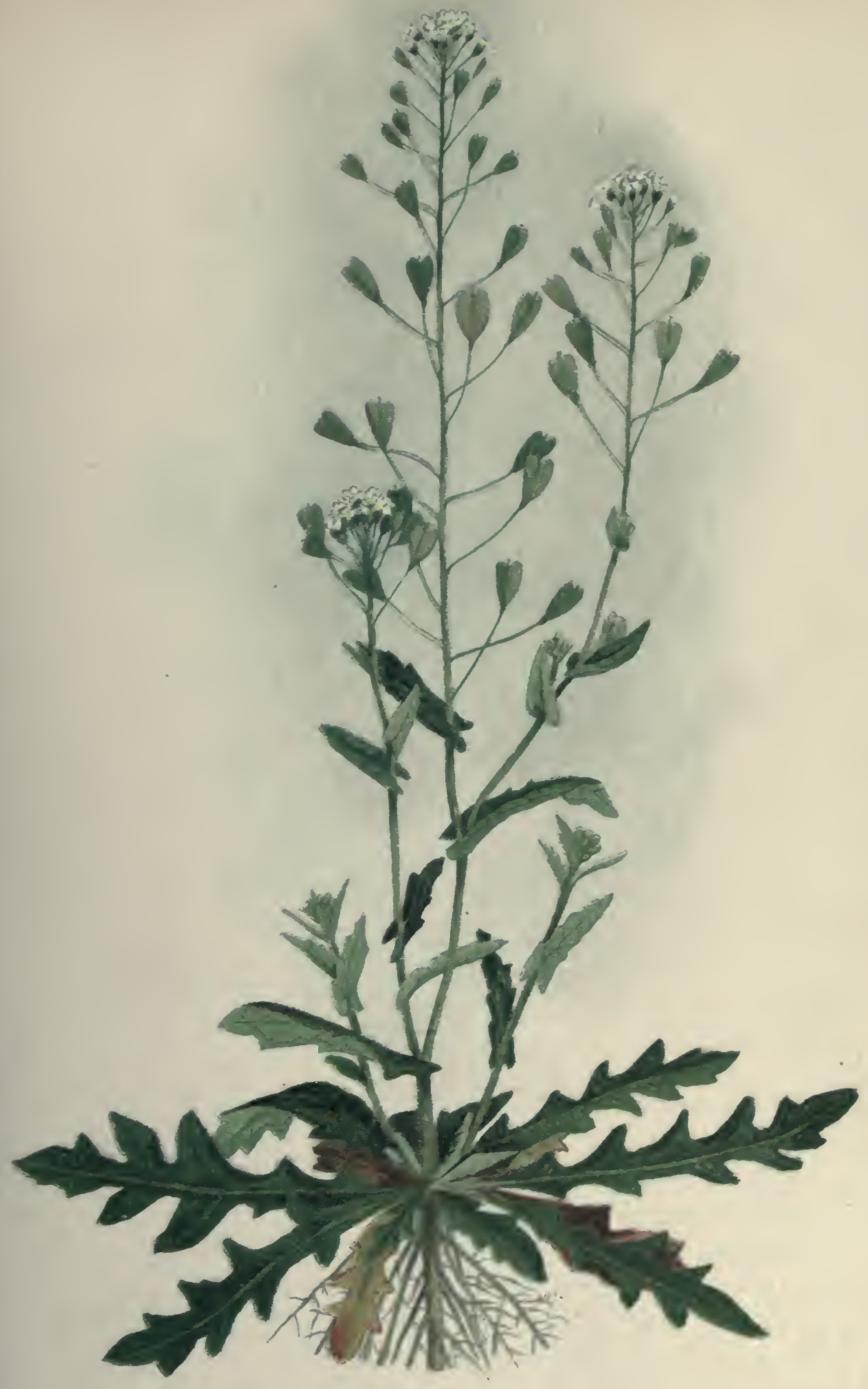

Plate 29

SHEPHERD'S PURSE

(Capsella Bursa-pastoris (L.L.Moriar) 

Time of flowering: Throughout the season. At all times of the year when it is not actually freezing, this plant is growing and ripening its seeds.

Propagation: By seeds.

Occurrence: Throughout Canada, in all soils. The seed is found in all small commercial seeds.

Injury: It has an enormous power of propagation; a single plant will ripen 50,000 seeds. It will thrive in all kinds of soil, is of a succulent nature and absorbs much moisture. In meadows which have been thinned by winter, the vigorous rosettes of autumn-started plants will crowd out grass and clover. It is frequently attacked by fungus diseases and harbours those common to cabbage, turnips and other members of the Mustard family.

Remedy: The same general treatment as given for Peppergrass. Waste places should be cleared as far as practicable and seeded to grass. It does not give serious trouble on lands worked under a short rotation, with clean cultivation of hoed crops. Sow clean grass and clover seeds.

\footnotetext{
Grasse, thistle, and mustard seed, hemlock and bur, tine, mallow and nettle, that keep such a stur:

With peacocke and turkie, that nibbles off top, are very ill neighbors, to seely poor hop.
}

-Thomas Tusser, Five Hundreth Pointes of Husbandrie, 1557.

For Goose Tansey, or Hoare Tansey like Weed, I must needs make Proclamation That he that can tell the destruction of it, shall show a very acceptable service; and for my selfe I should be very thankfull for the Communication thereof, for I can say no more than this, Never Plough your Land too long, nor out of heart or strength by no meanes, for this occasioneth it to grow more thick and fruitfully; and also load your land hard with cattle in the spring and when it doth grow high and strong, Mow it downe about the end of Mid summer Moon, or in the dryest and hottest time of Summer, but the earlier the better, and other meanes I can proscribe none other, but in all your Plowings soyle it well with good Dung, and lay it down rich, and full of spirit, I hope some man. of experience herein will help me.

Walter Blith, The English Improver Improved, or The System of Husbandry Surveyed, 1652. 


\section{FALSE FLAX (Camelina sativa (L.) Crantz).}

Other English names: Gold of Pleasure, Balloon Mustard.

Other Latin names: Myagrum sativum L.; Camelina Macrocarpa Reich.

Introduced from Europe. Annual and winter annual, 2 to 3 feet high, erect, branched above. Root-leaves lance-shaped and narrowed into a footstalk; upper leaves arrow-shaped, sharply pointed. The lower leaves and the lower part of the stem downy with star-shaped hairs. The upper part of the stem smooth and covered with a fine bloom. Racemes much elongated in fruit. Flowers numerous, small, 1/8 of an inch across, pale greenish yellow. Pods $3 / 8$ of an inch long, balloon or pearshaped, margined and tipped with a slender beak, on slender footstalks, curving upward, each containing about 10 seeds.

The seed (Plate 73 , fig. 32 ) is variable in size, about $1 / 12$ of an inch long, pale yellowish brown. The miniature root of the germ very prominent, lying along the seed. Seed-coat finely pitted. Scar of attachment a white point in a notch at the base of the seed. When soaked in water the seeds develop a thick coat of mucilage. The seeds have been used as food on account of their mucilage and oil, both of which resemble those of linseed. The plant has been cultivated for these products in Germany and France.

Time of flowering: June to August; seed ripe July to September,

Propagation: By seeds.

Occurrence: Throughout Canada in waste places and along railways. A noxious weed in the West and in western Ontario.

Injury: In western Canada it is in evidence in grain sown on stubble land that has not had clean cultivation before spring seeding. It is a noxious pest in fall wheat and is prevalent in 


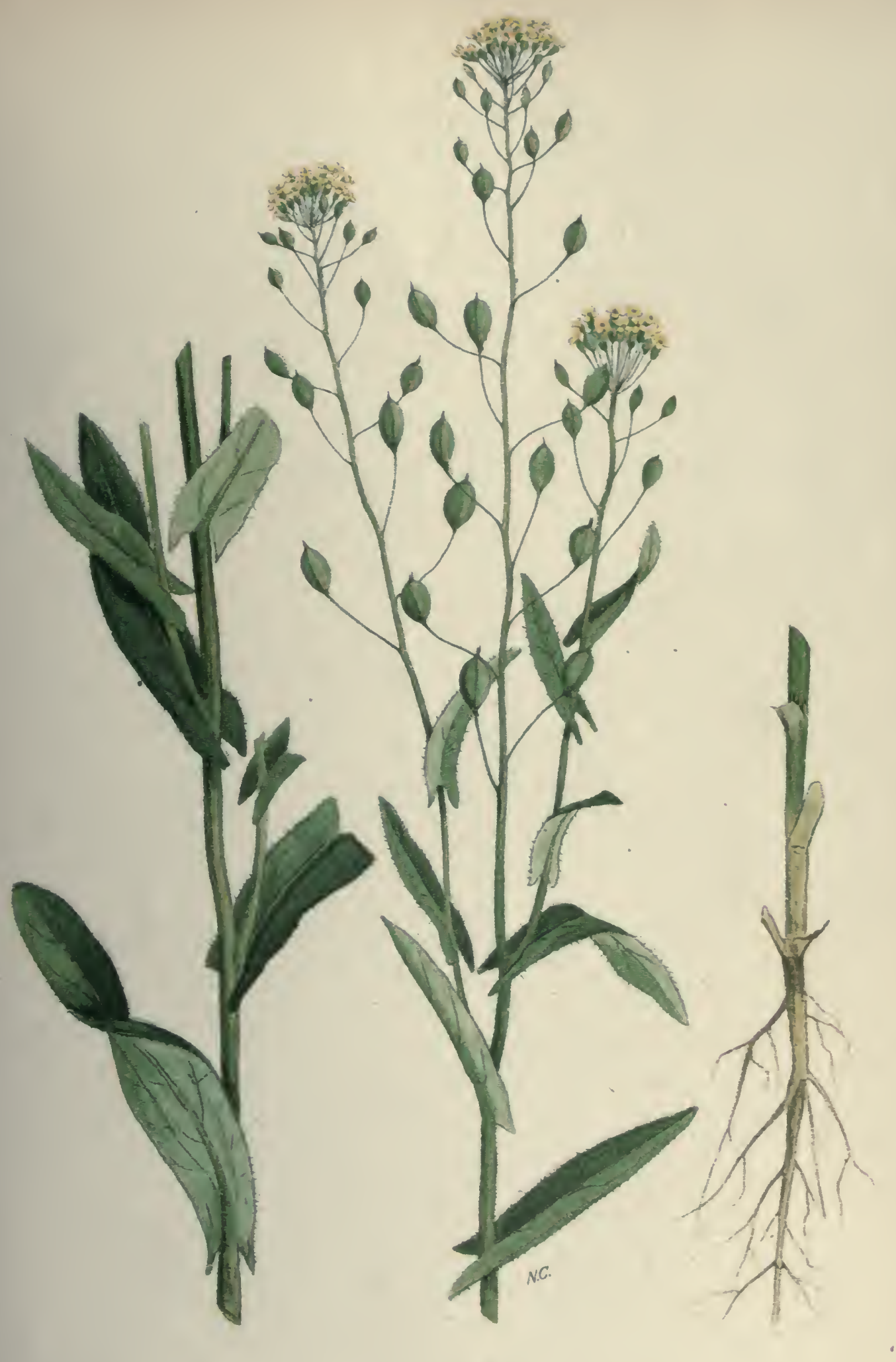

$$
\text { Plate } 30
$$

FALSE FLAX

(Camelina sariva (turimulz) 

clover fields and new meadows in fall wheat districts. Its disagreeable odour and flavour render it objectionable to all farm stock but sheep.

Remedy: Hand-pull small areas when practicable. Avoid winter crops on land polluted with seeds of this weed. Prairie soils infested with this winter annual should receive a thorough discing or shallow plowing in the spring before seeding. When a crop of winter wheat is infested with False Flax, harrowing in the spring kills the young plants without injuring the wheat. A thorough summer-fallow, with cultivation the previous fall and continuous cultivation throughout the summer, is recommended for fields badly infested with this weed.

ALLIED SPECIES: Small-seeded False Flax (Camelina microcarpa Andrz.) resembles common False Flax, but is more slender and has smaller pods. The first cutting of red clover containing this weed should be taken early. The first crop of alsike in the fall wheat districts usually contains some False Flax and should not be taken for seed unless the weeds are first hand-pulled and destroyed. This pest does not long give serious trouble where a short rotation of crops is practiced and where thorough cultivation and seeding to grasses is done with spring grains instead of fall wheat. The seeds (Plate 73 , fig. 33 ) are only about $1 / 20$ of an inch long, oblong in outline, plump, dark reddish brown. They often occur in large quantities in alsike clover and timothy seeds.

Round-seeded False Flax (Camelina dentata Pers.) was introduced into Manitoba in 1906 with imported flax seed. The seeds (Plate 73 , fig. 34 ) vary much in form and size, being generally larger than those of common False Flax, irregularly oval or oblong in outline, thickly flattened and pale yellow in colour.

\footnotetext{
In May get a weedhook, a crotch and a gloue, and weed out such weeds, as the corne doth not loue: For weeding of winter corne, now it is best, but June is the better, for weeding the rest. 
BALL MUSTARD (Neslia paniculata ( $\left.\mathrm{I}_{\text {.. }}\right)$ Desv).

Other English names: Yellow-weed, Neslia.

Other Latin name: Myagrum paniculatum L.

Introduced from Europe into the West about the same time as Tumbling Mustard, Hare's-ear Mustard and Cow Cockle. A tall annual or winter annual. Stems ereet, very slender; strong plants throwing out a few long branches. Whole plant yellowishgreen and eovered with small, appressed, star-shaped hairs. Lower leaves lance-shaped, narrowed at the base; stem-leaves arrow-shaped elasping the stem at the base, blunt-pointed. Flowers small, $1 / 8$ of an inch across, orange-yellow; racemes very long.

The seed (Plate 73, fig. 35) is enclosed in small, round, one seeded, shot-like pods, eommonly called "seed," which are borne on slender footstalks, about $1 / 2$ of an ineh in length, standing out from the stem in all direetions. These pods, when mature and dry, are about $1 / 12$ of an inch in diameter, roundish, greenish-brown, roughly net-veined, somewhat like a small piece of dry earth. The contained seed is yellow, with the miniature root of the germ prominent. The whole pods are generally found in grain, as they do not open to discharge the seeds.

Time of flowering: June to August; seeds ripe July to September.

Propagation: By seeds.

Occurrence: Very prevalent in northern Alberta; rapidly becoming more abundant in the other Prairie Provinees. Common in eastern Canada along railway lines, waste places and wherever western grain is carried.

Injury: A noxious weed in the grain crops of Manitoba, Saskatchewan and Alberta. The wrinkled pods or balls eontaining 


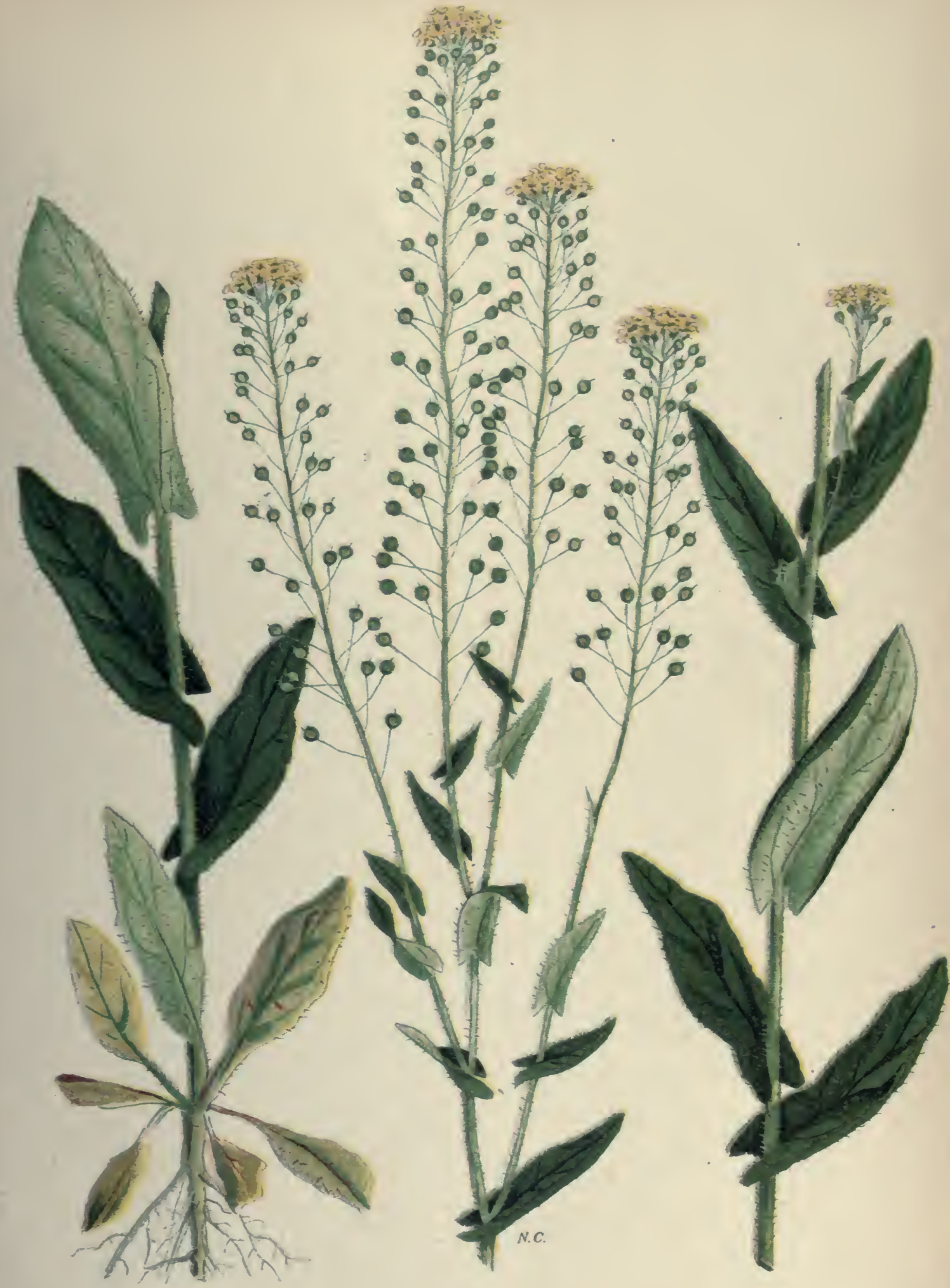

Plate 31

BALL MUSTARD

(Neslia paniculata (LIDesi) 

the small seeds are common in threshed grain, frequently necessitating dockage and recleaning at points of inspection and storage.

Remedy: Sow clean seed. This weed will not long give serious trouble where crop rotation is practiced. Where cereal grains follow cereal grains, plowing or discing in the fall and clean cultivation in the spring, with a disc or broad-shared cultivator, is recommended. Harrow the crop before the plants emerge from the ground, and again when they are three inches high, to destroy seedling weeds. Badly infested areas should be summer-fallowed; disc and harrow early in the spring and plow early in June. Seeding to grass for three or four years will greatly reduce this pest. The edges of prairie grain fields should be trimmed with the mower before these weeds have passed the flowering stage.

In some of the more northerly districts of the Prairie Provinces, where summer-fallowing is not expedient, growing grain for fodder gives an opportunity to clean the land of this pest. As with summer-fallow, begin with discing or early plowing immediately behind the binder in the fall. This should be followed by cultivation with disc or harrow early in the spring. The land should be plowed in June, thoroughly worked up, and seeded with oats, barley or timothy. Be sure to cut the crop before any of the mustard seeds mature.

Ball Mustard seeds are usually present in western oats sold for seed in Ontario, Quebec and the Maritime Provinces. Where clean seed can not be obtained, the fanning mill will eliminate these seeds by screening. The alternation of crops commonly practiced in mixed farming will usually keep this weed in check in eastern Canada. Sheep will feed on the young and tender plants of this weed and of most others of the Mustard family. 


\section{WILD RADISH (Raphanus Raphanistrum L.)}

Other English names: Jointed Charlock, Jointed Radish, Wild Turnip, often wrongly called Wild Mustard, Cadluck or Kale in Nova Scotia.

Introduced from Europe. Annual and winter annual, 1 to 2 feet high, with a few long branches starting low down. The root is slender, not swollen as in the garden radish. Leaves pale yellowish-green, deeply lobed, and, like the stem, bearing a few stiff bristles. The flowers are fewer and larger than in Wild Mustard, noticeably paler yellow, conspicuously veined. The constricted seed pods (Plate 73, fig. 36) are the most distinctive characteristic; with these, no mistake can be made in identifying the two plants. In Wild Radish the seed-pods have no valves but are composed of two joints, the lower one small, 1/10 of an inch, and seedless, which remains attached to the footstalk; the upper cylindrical, $1 \frac{1}{2}$ inches long, with several one-seeded cells formed by transverse partitions. This seed-bearing portion separates from the first joint, leaving it attached to the footstalk; in threshing, it is often broken up into single-seeded sections.

The seed itself (Plate 73, fig. 36) varies much in size and shape, being about $1 / 8$ of an inch long, oval, irregular, slightly flattened, reddish brown, the surface very finely netted.

Time of flowering: June to September; seeds ripe by August.

Propagation: By seeds.

Occurrence: Abundant in the Maritime Provinces and recently introduced with English seed oats into Ontario.

Injury: A coarse, vigorous weed, not less objectionable than Wild Mustard though not so difficult to suppress. Grain crops polluted with this weed are troublesome to harvest; the 


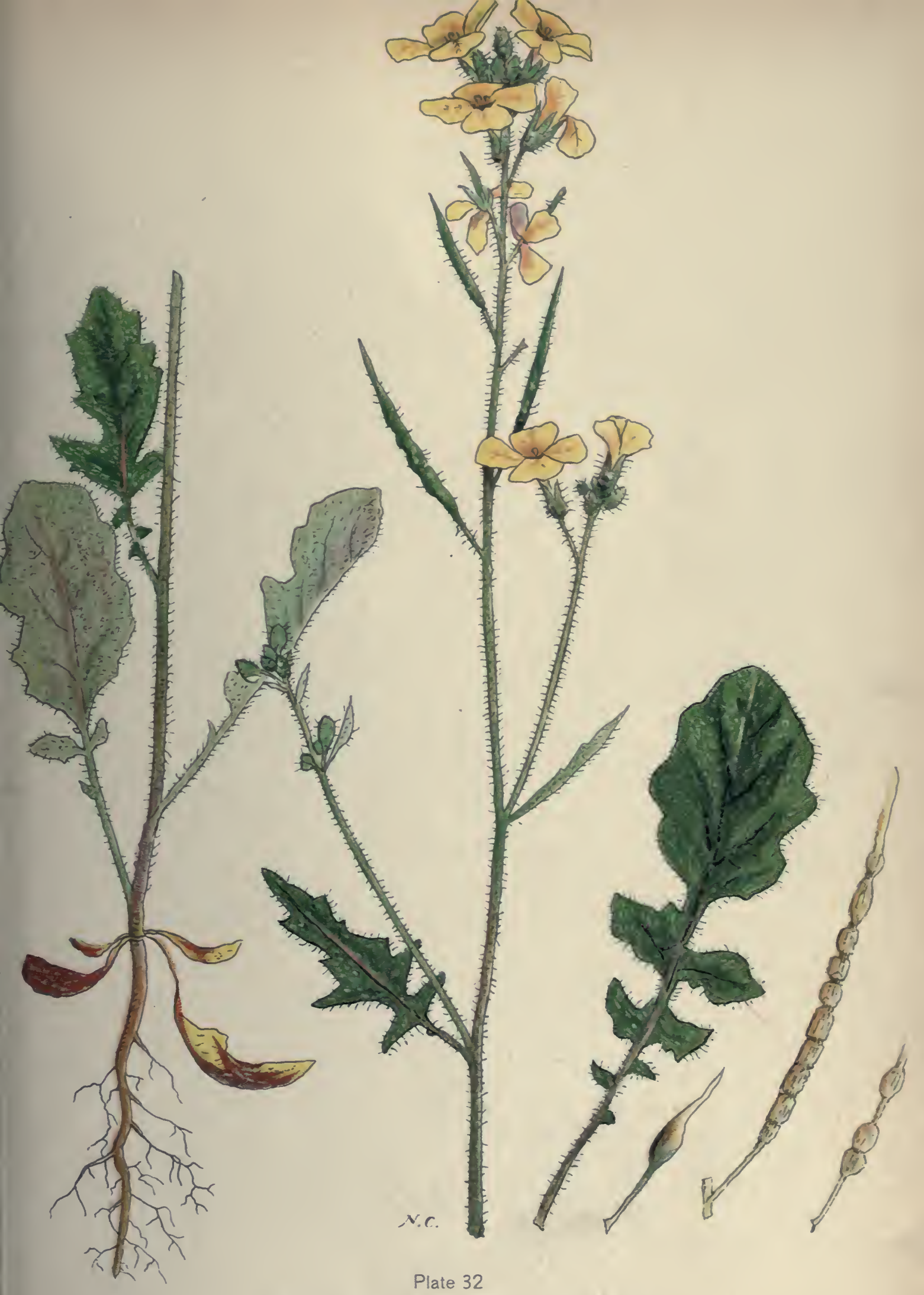

WILD RADISH OR JOINTED CHARLOCK

(Raphanus Raphanistrum $\mathrm{L}$.) 

bulky nature of the plants prevents the elevation of the grain in self-binders and greatly increases the amount of binder twine required. The broken seed pods, containing the seeds, are common in oats and reduce the market value of the grain.

Remedy: Sow clean seed grain. Hand-pull if at all practicable. If the weed has become established, a summer-fallow, with thorough cultivation at short intervals, will greatly reduce it. Hoed crops with clean cultivation, followed by a fodder crop, such as mixed grain to cut green, before Wild Radish has passed the flowering stage,- with early clover for pasture or hay the third year and a grass crop for hay the fourth year, is a rotation that will prevent this weed from seeding and will ultimately suppress it. If grain is desired after a hoed crop, it would be well to defer spring seeding and give thorough cultivation with the disc and broad-shared cultivator until the soil is sufficiently warm to produce a vigorous growth; then sow early-maturing, six-rowed barley, at the rate of three bushels per acre, and harvest the crop on the green side. If weather permits, apply the weeder or harrow when the barley commences to show above the surface, and again when the crop is from three to six inches high. The harrow will destroy most of the seedling plants of this and other annuals. The clover and grass seed should be sown in front of the harrow at the last application. Examine imported seeds for the broken pods of this weed. Sheep feed readily on the young plants of Wild Radish and if their pasture is short will prevent it from seeding.

Small herbs have grace; great weeds do grow apace:

.... Sweet flowers are slow, and weeds make haste.

-Shakespeare, Richard III, Act II, sc. iv, 1594.

In the later ende of May is tyme to wede thy corne. There be divers maner of wedes, as thistles, kedlokes (charlock), dockes, cocle, darnolde, gouldes, and dog fenell. The thystle is an yll wede, and there be other wedes, as dee nettylles, dodder, and suche other that doo moche harme. 


\section{WILD MUSTARD (Brassica arvensis (L.) Ktze.)}

Other English names: Charlock, Herrick, Cadluck, Fieldkale, Ontario Mustard.

Other Latin names: Brassica Sinapistrum Boiss., Sinapis arvensis $\mathrm{L}$.

Introduced from Europe. Annual. Stems ereet, branching, 1 to 3 feet high, rough, with stiff, somewhat downward directed hairs. The purple at the junction of the branches with the stem is a striking characteristic. Lower leaves stalked, usually deeply indented or lobed, with the terminal lobe large; upper leaves mostly stalkless. Flowers bright yellow, fragrant, $2 / 3$ inch across. Seed pods 1 to 2 inches long, knotty or slightly constricted between the seeds, ribbed and rising obliquely on short, thick footstalks, tipped with a long empty or 1-seeded, 2-erged beak, which breaks away whole from the ripe pod. Each pod contains about 15 to 17 seeds.

The seeds (Plate 73 , fig. 37 ) vary somewhat in size but are generally about $1 / 16$ of an inch in diameter, quite round, dark brown or reddish black, almost smooth and without mucilage.

Time of flowering: June to September; seed ripe by August. Propagation: By seeds.

Occurrence: General throughout Canada in farm crops and waste places.

Injury: A gross feeder and a troublesome weed. The commonest and one of the most injurious weeds belonging to the Mustard family.

Remedy: Sow clean seed and hand-pull to prevent it becoming established on new or clean land. When ripe the pods split and much of the seed is left on the land at harvest time; thus the plant rapidly increases on land devoted to cereal grain, particularly oats. Harrowing or discing the stubble lands 


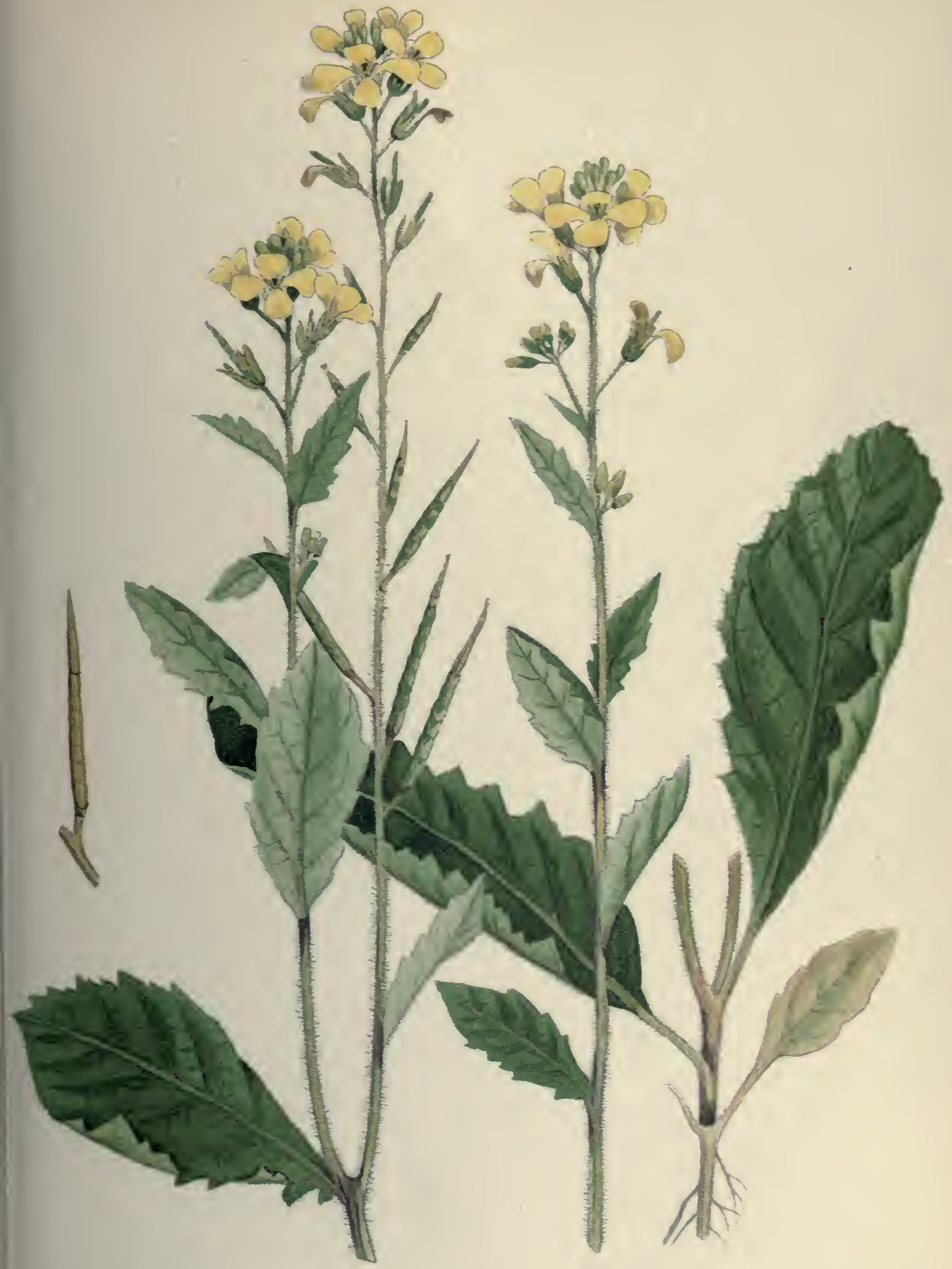

Plate 33

WILD MUSTARD OR CHARLOCK

(Brassica arvensis (u)hita) 

directly after harvest will induce the seed of this and other annuals to germinate; the plants make good feed for sheep or may be destroyed by cultivation or frost. A rotation of crops such as recommended for Wild Radish will suppress this pest. On lands where the production of spring cereal grains predominates, two or more applications of the weeder or harrow, preferably a tilting harrow, once when the grain begins to show above ground and once or twice when the crop is between three and six inches high, will destroy the seedling mustard plants and prevent them from choking out the grain. Some claim that this practice of harrowing spring crops slightly delays maturity, but this can be obviated by thicker seeding. Applications of clover and grass seed may be made directly in advance of the harrow when last applied. When the soil is too wet to use the luarrow, as it frequently is during the early growing season, in the eastem provinces, the growth of Wild Mustard may be checked and most of the plants killed by spraying with a solution of $t$ wo pounds of bluestone in ten gallons of water, applied at the rate of about fifty gallons per acre in a fine spray. The seeds are longer-lived than most others of the Mustard family. Recent research work showed that they do not retain their vitality beyond fifteen years.

ALLIED SPECIES : Indian Mustard (Brassica juncea (L.) Cosson) differs from Wild Mustard in being smooth, nearly hairless, somewhat covered with a fine bloom. The upper leaves are narrower, the lower ones pinnatifid with a large terminal lobe. The pods are slightly shorter on spreading footstalks. This weed has been detected in a few places in Manitoba and Ontario.

Black Mustard (Brassica nigra (L.) Kóoch). Although found occasionally in all the provinces, the true Black Mustard does not seem to be a troublesome weed in Canada. It may be at once known by its long spreading branches, covered with short square pods only half an inch long, which are erect and closely appressed to the stem.

Bird or German Rape, Rutabaga (Brassica campestris L.) including Turnip (BrassicaRapa L.) and Rape (Brassica Napus L.) 
resembles Wild Mustard, but only the root-leaves are hairy. The stem, the upper leaves which clasp the stem by an ear-shaped base, and the long pods on spreading footstalks, are smooth and waxy, like the leaves of eabbage. This form is abundant in Manitoba and in some parts of Quebec and Ontario. Bird Rape, _unlike Wild Mustard, ean not be killed by spraying with bluestone solution, on account of its smooth leaves to which the solution will not stick.

Rocket or Rocket Salad (Eruca sativa Lam.) has recently been introduced into Ontario, probably with European alfalfa seed. It is a hairy annual, somewhat resembling Wild Mustard. The leaves are pinnatifid, with a large terminal lobe. The flowers are yellowish-white, characteristically netted with dark purple veins, aromatic. The pods are shorter than those of Wild Mustard, upright, the beak broad and flat. The seed is about the size of that of Bird Rape, flattened, olive-brown, the miniature root of the germ generally lighter in colour. It is pungent and bitter, with a flavour characteristic of radish. The seed is occasionally present in European alfalfa seed. The plant is seldom referred to as a noxious weed in Europe, where it is sometimes cultivated as a pot herb. It should not be allowed to mature its seeds in cultivated crops.

HARE'S-EAR MUSTARD (Conringia orientalis (L.) Dumort.).

Other English names: Rabbit-ear, Hare's-ear Cabbage, Klinkweed.

Other Latin names: Erysimum orientale R.Br.; Brassica orientalis L.; Brassica perfoliata Lam.

Introduced from Europe, probably with flax seed, about 1892. Annual and winter annual. Stems erect, with a few branches, 1 to 4 feet high. Whole plant perfectly smooth, and, when young, covered with a fine bloom like that of cabbage. Leaves fleshy, without teeth, the root-leaves obovate, gradually 


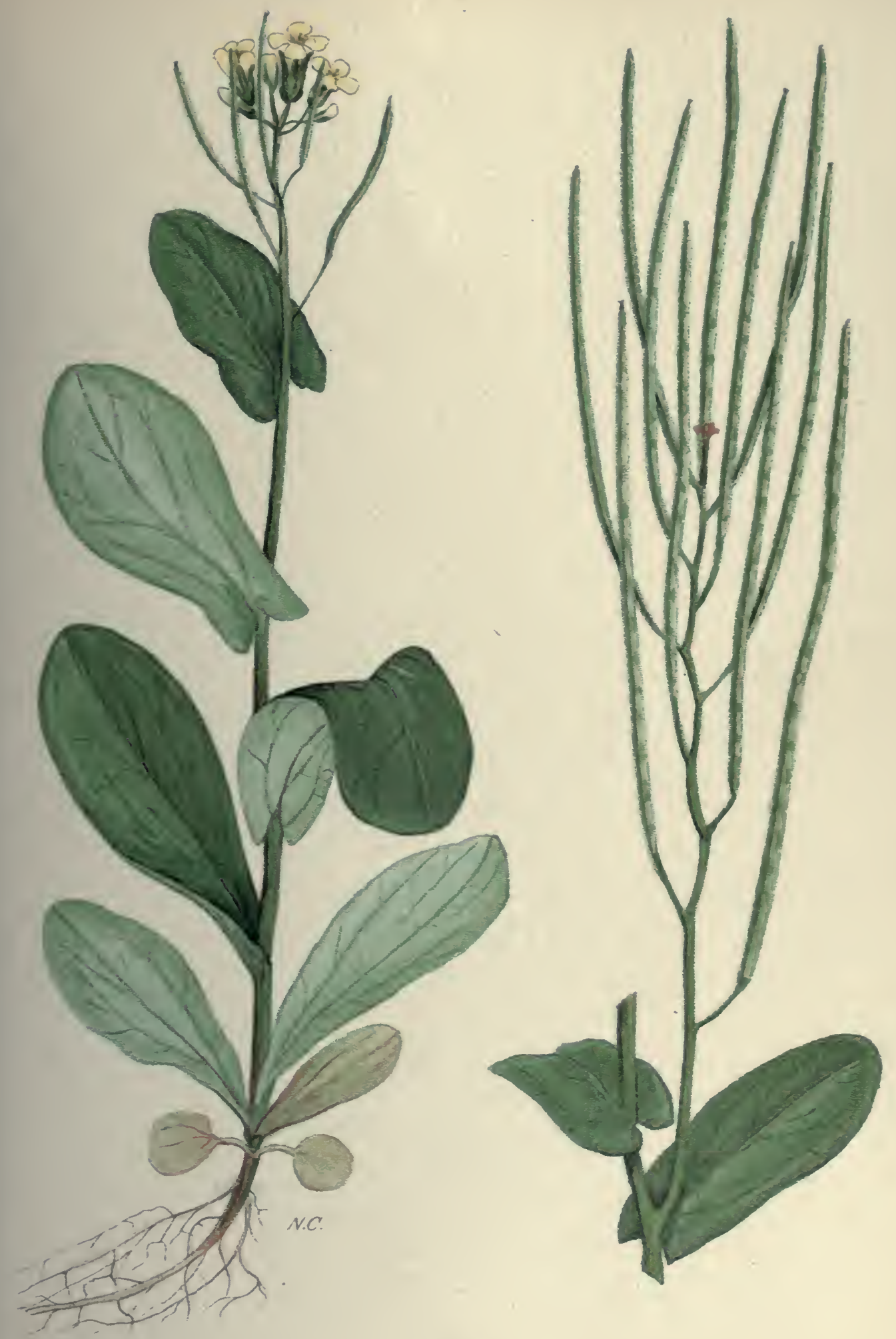

Plate 34

HARE'S-EAR MUSTARD

(Conringia orientalis "in)mment) 

narrowed to the base; those on the stiff stems, which become wire-like when ripe, oblong oval, shaped like a hare's or a rabbit's ear, clasping the stem by two rounded, ear-like lobes. Flowers creamy-white, $1 / 4$ inch across. Pods square, 3 to 4 inches long.

The seed (Plate 73, fig. 38) is dark brown, rounded-oblong, pointed at the scar end, 1/12 of an inch long, granular roughened; when soaked in water, covered with short, erect, white, mucilaginous hairs. In shape it resembles the seed of common False Flax.

Time of flowering: End of June; seeds ripe AugustSeptember.

Propagation: By seeds.

Occurrence: Quite general throughout the West, especially in southern Alberta, in grain fields, on stubble and by roadsides; spreading rapidly.

Injury: A coarse growing weed which occupies much space. The succulent plant absorbs moisture from the soil and little grain can grow where there is a patch of it. The wiry stems are hard to bind and are bad for reaping and binding machines; an infested crop requires more labour to handle and more twine to bind. The seeds are common in commercial grain and in flax; clean virgin soil is often polluted with it through sowing flax on newly broken land. The plant is a harbour for insect and fungus pests injurious to cultivated crops of allied species, particularly to turnips and cabbage.

Remedy: Sow clean seed. Hand-pull small. patches when the weed makes its first appearance. When the grain is three inches high, use the harrow to destroy the seedling weeds. This practice, combined with discing immediately after harvest and thorough summer-fallowing once in three years, will keep this weed in check and ultimately exterminate it. Badly infested areas may be seeded to grass for three or four years as few plants will mature seeds in a well-established timothy or western 
rye grass sod. When embedded in moist soil the seeds do not long retain their vitality.

Hare's-ear Mustard has frequently been introduced into mixed farming distriets but does not long give serious trouble where systematie erop rotation is praeticed. Sheep seem to like the young succulent plants almost as well as rape and other eultivated speeies belonging to this family.

TUMBLING MUSTARD (Sisymbrium altissimum L.).

Other English names: Tall Sisymbrium, Tumble Mustard.

Other Latin names: Sisymbrium sinapistrum Crantz; Sisymbrium pannonicum Jaeq.

Introduced into the Prairie Provinees from eentral and southern Europe about 1887. Annual and sometimes winter annual; 2 to 4 feet high, stem branehing, the lower part and the root-leaves downy and glandular, with a nusky odour; upper part of the stem and the mueh-divided leaves smooth. The young plants form a rosette of soft, pale green, downy leaves, shaped much like those of Common Dandelion. On the flowering plants the leaves ehange very much in shape from the root up, no two being alike. Flowers pale yellow, $1 / 3$ ineh in diameter. Seed pods 2 to 4 inehes long, very slender and produced abundantly along the branches. Each pod contains about 120 seeds, and a single plant has borne as many as $1,500,000$ seeds. When the seeds are ripe the whole head of the plant breaks off and is blown aeross the prairie, seattering the seeds far and wide. The seeds, as in many "tumbling weeds," are not easily shed from the tough pods; consequently a head of this weed may blow about the prairie for a whole winter, dropping a few seeds at intervals for many miles.

The seed (Plate 73, fig. 39) is small, 1/25 of an inch long, olive brown or greenish yellow, minutely roughened with muei- 
laginous glands, oblong, angular, cut off transversely at the scar end, sometimes almost square from compression in the pod, grooves conspicuously darkened. The miniature root of the germ prominent and plainly visible through the thin skin.

Time of flowering: June to July; seed ripe in August.

Propagation: By seeds.

Occurrence: In grain fields, roadsides and neglected fire guards in the West. Occasionally found along railways and in waste places in other parts of Canada, but not as a farm weed.

Injury: This is one of the mustards with all the bad characteristics of these aggressive enemies of the farmer; enormously prolific, with great power to spread, owing to its tumbling habit, a coarse conspicuous plant and a gross feeder. When abundant it seriously interferes with cutting and elevating the crop by self-binders and greatly increases the amount of twine required. The seeds give an objectionable flavour to ground grain, and farm stock, with the exception of sheep, refuse to eat it when it is present in quantity.

Remedy: Harrowing spring grain, as recommended for other mustards, is effective; if this is done, Tumbling Mustard will give little trouble. Discing in the fall immediately after harvest and clean cultivation before seeding in the spring are recommended. Screenings containing the seeds should be destroyed. Plants about the edges of fields, along roadsides and fireguards should not be allowed to mature. New and reasonably clean fields may be kept clean by hand-pulling.

\section{ALLIED SPECIES: Hedge Mustard (Sisymbrium officinale} (L.) Scop.) is a common weed along roadways and waste places, widely distributed throughout Canada. It seldom gives serious trouble in fields. The plant is from 2 to 3 feet high and of a ragged appearance, with small, lobed leaves, small pale yellow flowers and thick-walled slender pods, which become hard and brittle when mature and are closely pressed to the few-branched stem. This weed is easily destroyed along roads and waste places by cutting to prevent it from seeding. 
GREEN TANSY MUSTARD (Sisymbrium incisum Engelm., var. filipes Gray)

Other English name: Cut-leaved Tansy Mustard.

Other Latin name: Sophia incisa (Engelm.) Greene.

Native. Biennial; in the first season, a rosette of finely divided leaves lying on the ground. Stems, 3 to 4 feet, erect, widely branching at the top and bearing an enormous number of narrow, smooth, slightly curved pods, from $1 / 2$ to $3 / 4$ inch long, on slender, spreading footstalks. Whole plant bright green and somewhat glandular. Leaves pinnatifid, each division sub-divided into 2 or 3 linear-oblong segments, with or without teeth. Flowers yellow, $1 / 8$ inch across in an elongated raceme.

The seed (Plate 73, fig. 40) is small, 1/25 of an inch long, oblong, sometimes compressed at the scar end, reddish brown, minutely roughened with mueilaginous hairs.

Time of flowering: July; seeds ripe in August.

Propagation: By seeds.

Occurrence: In grain crops in the Prairie Provinces and British Columbia. A wayside weed in eastern Canada, where it is common along railways and where western grain or mill feeds have been' distributed.

Injury: A weed of rank growth and branching habits that crowds out grain, greatly redueing the yield. Its bulky nature makes the operation of harvesting machinery difficult and extra binder twine necessary.

Remedy: The prevalence of this biennial mustard in grain fields of the Prairie Provinces is largely due to the practice of sowing cereal grains on stubble land, with only surface cultivation in the fall or spring to produee a suitable tilth for a seer-berl, without first destroying weed growth by plowing, thorough discing or the use of a broal-shared cultivator. Summer-fallows 


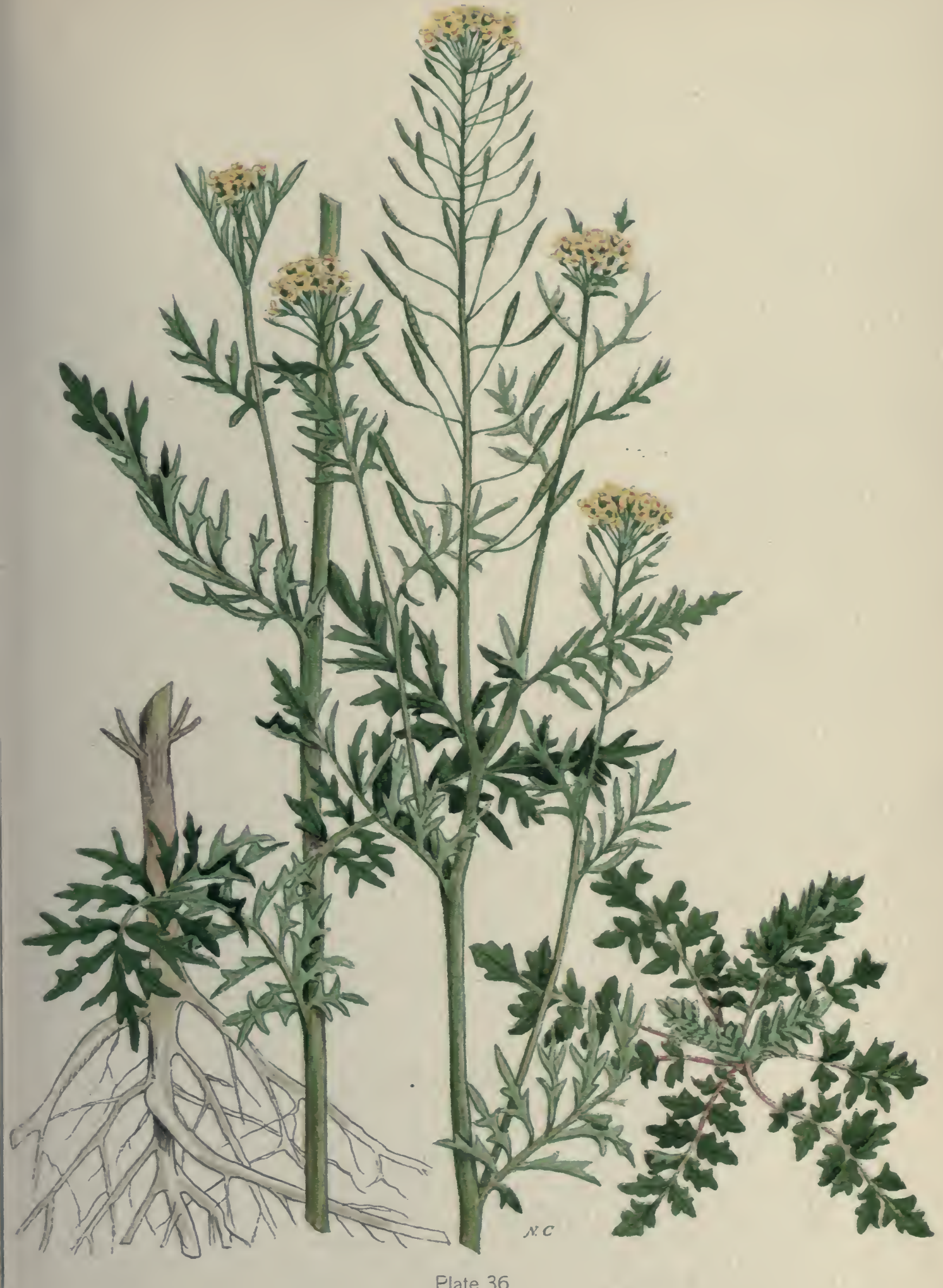

Plate 36 

where this weed gives trouble should receive clean cultivation until late in the fall. Where Tansy Mustard is troublesome in winter wheat, harrowing in early spring will tear out the rosettes without injuring the wheat. Waste places where it thrives should be sown to permanent grass and the weed growth kept cut until the grass has possession of the soil. Frequent cutting will prevent it from seeding along roadways and the borders of fields.

\section{ALLIED SPECIES: Gray or Crowded Tansy Mustard} (Sisymbrium incisum Engelm., var. Hartwegianum (Fourn.) Watson) is also a tall, coarse biennial, with much divided foliage like the above, but differs by being covered with short, gray, downy hairs and in its more erect habit of growth. It has pods only $1 / 4$ inch long, all crowded close to the slender branches which form a narrow spike-like raceme. Gray Tansy Mustard is the commoner and more widely distributed plant of the two. It flowers and ripens its seed some weeks later.

The seed (Plate 74, fig. 41) resembles that of Green Tansy Mustard in shape and colour but is smaller, a little more flattened by compression in the pods and more abruptly cut off transversely.

These two coarse biennials grow only from seed, but they throw out long branches from their white tap roots and draw nourishment from a wide area. As they stand considerably above the crop, they are a conspicuous advertisement of negligent farming.

Now is the time, before the thistle blow, While gule is in the flower, and charlock breathes Its cloying scent around, the weeding task To urge between the turnip's verdant ranks. Emburied by the double mould-board, down On either side the noxious race are laid. While, by the waves of crumbling earth heared up, The plants are cherished. 


\section{WORM-SEED MUSTARD (Erysimum cheiranthoides L.)}

Other English name: Treacle Mustard.

Native. Annual and winter annual. Stems erect, simple or branching, 6 inches to 2 feet high. Whole plant sometimes slightly hoary with short, star-like hairs. Leaves dark green, lance-shaped, sparsely toothed. Flowers bright yellow, 1/5-inch across, in terminal clusters about 1 inch across, on gradually elongating racemes. Seed-pods slightly curved, from $1 / 2$ to 1 -inch long, obtusely 4-angled, erect on spreading footstalks. Each pod contains about 25 seeds. An average plant will ripen about 25,000 seeds.

The seed (Plate 74, fig. 42) varies somewhat in size and shape, generally pointed at one end, rounded at the other, about $1 / 24$ of an inch long, reddish yellow, with a dull surface but al most destitute of mucilage. Scar end darkened. The miniature root of the germ is conspicuous. The seeds are very bitter.

Time of flowering: June to autumn; seeds ripe July to frost.

Propagation: By seeds.

Occurrence: Frequent in waste places and on cultivated land throughout Canada.

Injury: On account of the pungent flavour, stock will refuse to eat grain in which these seeds are present in any appreciable quantity. It is a common weed in clover fields and is avoided by all farm stock, except sheep, either in pasture or in cured hay. If neglected, it will grow in dense masses and crowd out crops. The seeds are frequently found in grass and clover seeds.

Remedy: The seeds are short-lived, and this mustard is kept well under control on land worked under a short crop rotation with clean cultivation. In districts where cereal grains predonimate, the cultivation of bare stubble land, as recommended for other mustards, followed by discing in the spring before seeding, will keep this pest in check. The seeds can be cleaned from clover seed by screening. 


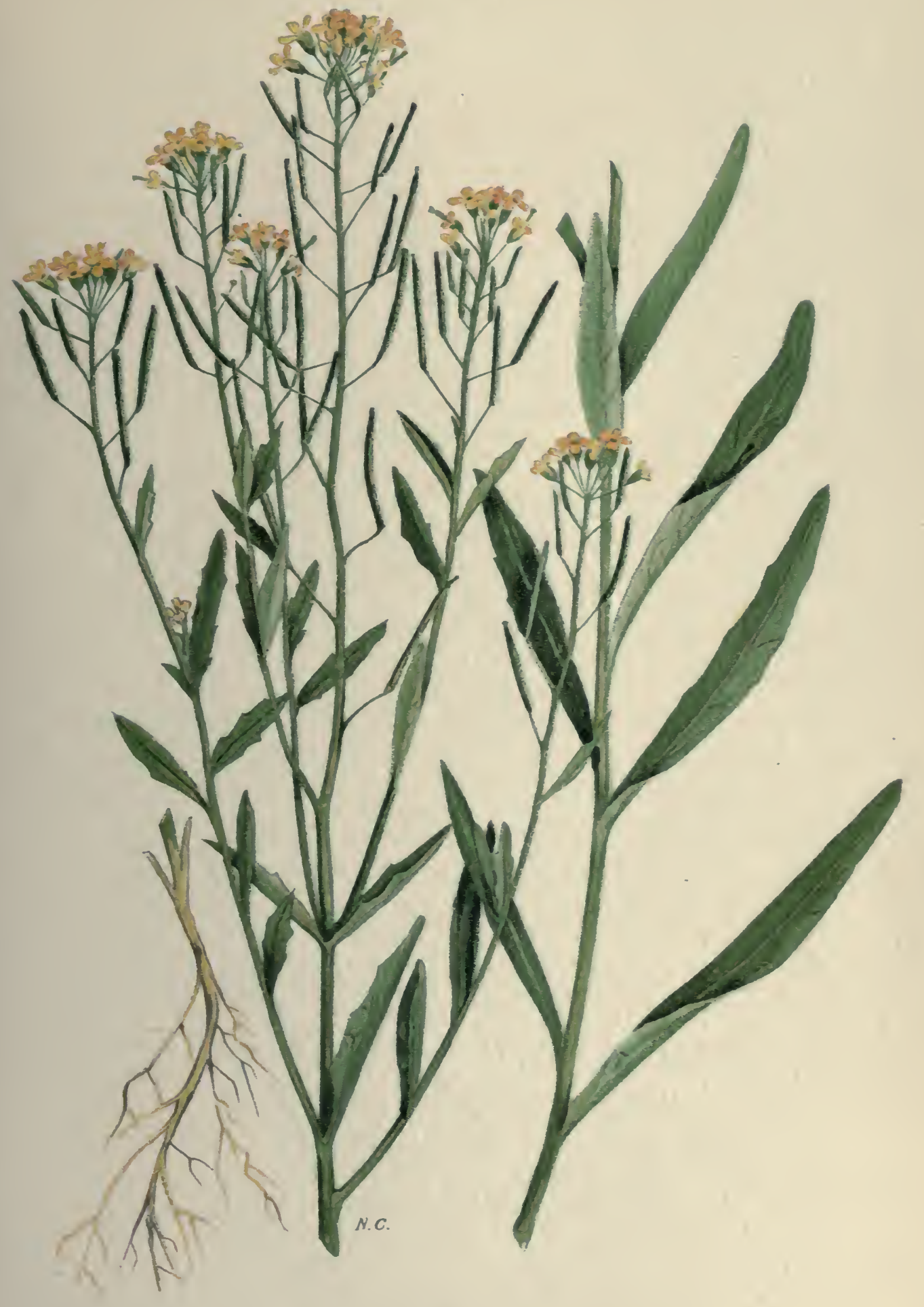

Piate 37

WORM-SEED MUSTARD

(Erysimium cheiranthoides L.) 

ALLIED SPECIES: Small Erysimum (Erysimum parviflorum Nutt.) is a perennial species commonly met in Ontario as a wayside weed, occasionally giving trouble about the edges of fields and in old meadows and pastures. It is widely distributed in western Canada, but not so abundant as Worm-seed Mustard. It is less branched than the former species, the leaves more slender, and the pods much longer, on shorter footstalks.

Western Wall-flower or Prairie Rocket (Erysimum asperum D.C.). A prominent object on dry, gravelly soil throughout the prairie region. The plant is characterized by its minutely roughish-hoary appearance, lance-shaped to linear leaves, bright orange yellow flowers, and long, almost erect pods.

Yellow Rocket or Yellow Weed (Barbarea vulgaris R. Br.). A common and conspicuous wayside weed along the Atlantic Coast. A smooth perennial, lower leaves much divided, the terminal division round and usually large, upper leaves obovate, pinnatifid at the base, pods erect or nearly so, on spreading footstalks.

Rock Cresses (Arabis), many of which are widely distributed throughout Canada, seldom give serious trouble as farm weeds. Tower Mustard (Arabis glabra (L.) Bernh.) is a representative of this genus and is commonly seen along railways and in waste places. The general characteristics of the genus are: long, somewhat flattened seed-pods, leaves seldom divided, and flowers usually white or purple.

A rural charm against dodder, tetter, and strangling weeds, is by placing a chalked tile at the four corners, and one in the middle of our fields, which, though ridiculous in its intention, was rational in the contrivance, and a good way to diffuse the magic through all parts of the area. 


\section{THE CAPER FAMILY (Capparidaceae).}

Closely allied to the Mustard is the Caper family, which has some important characteristics in common with it, such as cross-shaped flowers, seeds in pods, but these without partitions, and of ten aerid or pungent juice. The chief differences between the two families are that in the Mustard family four of the six stamens are long and two short, while in the Caper family all six are equal, and the pods of the former are two-celled and usually divided by a thin partition across the middle.

Spider-flower or Stinking Clover (Cleome serrulata Pursh.) is a native annual, tall, smooth, hairless, with erect stem, branched above and alternate leaves composed of 3 leaflets, spreading from the apex of the footstalk, like the fingers of a hand. Flowers pink or white, showy. The pods are long and narrow, striped, and many seeded.

The seed (Plate 74 , fig. 44) is round-wedge-shaped or elongated-kidney-shaped, with a deep curved groove running up each face $2 / 3$ of the way to the top from just above the sharp-pointed base. When ripe it is dark brown, roughened with pale, seurfy protuberances; the dry unripe seed is yellowish. Sometimes found in cereal grain.

A persistent weed that occasionally gives trouble in cereal crops in the Prairie Provinces. In crops sown on stubble, it frequently forms dense masses that crowd out the grain. Prevent the plant from producing seed on fire-guards and around the edges of fields by mowing in July and August. Areas badly infested should be summer-fallowed. Stubble lands should be shallow-plowed or thoroughly disced in fall or spring.

Clammy-weed (Polanisia graveolens Raf.) is a low-growing wayside weed with an unpleasant smell and sticky, hairy leaves, having 3 oblong leaflets. Common along railways and in waste places in the Eastern Townships of Quebec, Ontario and western Canada; occasionally giving trouble in eultivated erops. 


\section{THE ORPINE FAMILY (Crassulaceae).}

Succulent herbs with flowers having as many or twice as many pistils as calyx and corolla divisions, usually borne in cymes. Leaves stalkless, generally fleshy. Plants of this family are also commonly called Stonecrop.

Live-for-ever (Sedum purpureum Tausch) is a cultivated plant with thick stems about 2 feet high and fleshy oval stalkless leaves. When occurring as a weed it is difficult to suppress. It spreads principally from the root, but parts of the stems distributed by the plow or cultivator will root and rapidly develop into vigorous plants. Where well established, it excludes other cultivated plants.

When under cultivation it should be closely guarded. Occasional plants may be destroyed by the application of salt about the stems in dry hot weather. Where well established, the land should be given over to bare fallow with frequent cultivation of a kind that will unearth the underground regetation, so that it can be burnt or otherwise destroyed.

\section{THE ROSE FAMILY (Rosaceae).}

The Rose family is more remarkable for ornamental and fruit bearing plants than for agricultural pests. It is extensive and contains plants with regular flowers and alternate leaves, generally having appendages on each side of the footstalk, by which their relationship is shown. They present great diversity in their fruit which may be papery and pocket-like as in the meadowsweets, fleshy and urn-like as in the roses, succulently fleshy as in the raspberry and strawberry, or hard and dry as in the cinquefoils.

To this family belong the most troublesome Prairie Roses (Rosa pratincola Greene or Rosa arkansana of Canadian writers, 
which includes Rosa acicularis, var. Bourgeauiana Crépin). In southern Manitoba this dwarf, large-flowered rose is very persistent. Its deep, perennial rootstocks send up many flowering shoots from the axils of the scales.

The seeds (Plate 74, fig. 46) vary greatly in size and shape, averaging about $1 / 6$ of an inch long, generally irregular, angular, with hard, yellowish shells. They are often found in the sereenings of western grain.

To destroy roses, the land should be plowed with a sharp plow in hot weather and then twice disced at intervals of a week or ten days. T. N. Willing recommends deep spring plowing rather than stubble cropping for land infested with Wild Rose and similar shrubs.

\section{HARDHACK (Spiraea tomentosa L.).}

Other English name: Steeple Bush.

Native. Perennial. A pretty, dwarf shrub, 2 to 3 feet, with short-stalked, ovate, thick, toothed leaves, smooth above but lowny beneath. The flowers are pink, rarely white, borne on erect branehes in dense, steeple-like terminal panicles.

The seeds are enclosed, several together, in a downy, papery pocket, whitish at the base, pink to brown from the midldle to the tipped apex. They are linear, about $1 / 16$ of an inch long, white to brownish, with a thin, loose coat.

Time of flowering: July to September; seed ripe September.

Propagation: By seeds.

Occurrence: Especially in low rich soils in open woods, rocky places and about lakes, from Nova Seotia to Georgian Bay; abundant in Quebec.

Injury: This native Hardhack does not long give trouble on land brought under cultivation and crop rotation with frequent 


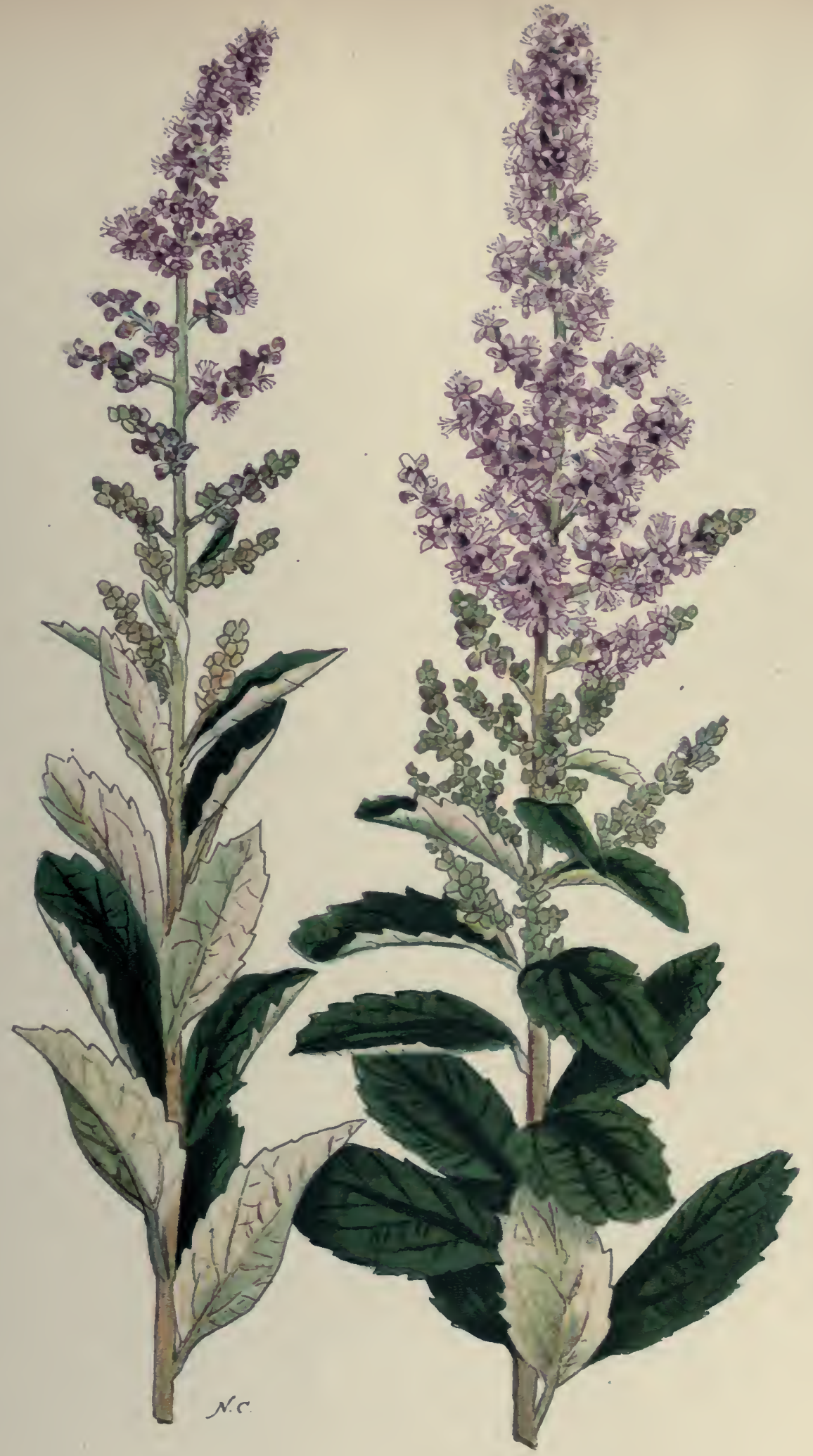

Plate 38

HARDHACK OR STEEPLE BUSH

ISpiraea romentosa /.. 

plowing. It rapidly spreads and takes possession of rich, moist pasture lands.

Remedy: Repeated cutting, to prevent it from seeding, will keep it in check. A handful of salt, applied after close cutting in hot weather when the soil is quite dry, will kill the root; this may be practicable on areas where the pest is not very abundant. Hand-pulling is recommended for loose land in which portions of the roots are not apt to break off and remain in the soil. If at all possible, land over-run with this weed should be cleared and brought under cultivation with a summer-fallow, entailing two or three plowings before it is put under crop. Sheep are said to feed on the young and tender plants when their favorite pasture grasses are short.

ALLIED SPECIES: Meadow Sweet (Spiraea salicifolia L.) in its several forms is occasionally met in low places, from Nova Scotia westward to the Rocky Mountains, where it was found by J. W. Macoun. It has tough, yellowish-brown stems, leaves dentate like a fine saw; flowers white, arranged in contracted, cylindrical panicles covered with matted, woolly hairs.

\footnotetext{
And Fumitory too, a name

Which Superstition holds to fame,

Whose red and purple mottled Flowers

Are cropped by maids in weeding hours,

To boil in water, milk, and whey,

For washes on a holiday,

To make their beauty fair and sleek,

And scare the tan from Summer's cheek.
}

-Clare, 1820.

And because ignorance is the chief cause of neglect of many rare things, which happen to their view at sometimes, which are not to be seen again peradventure, or not in many yeares after, I would heartily advise all men of meanes, to be stirred up to bend their mindes, and spend a little more time and travell in these delights of herbes and flowers, than they have formerly done which are not onely harmlesse, but pleasurable in their turn, and profitable in their use. 


\section{UPRIGHT CINQUEFOIL (Potentilla monspeliensis L.)}

Other English name: Rough Cinquefoil.

Other Latin name: Potentilla hirsuta Michx.

Native. Annual. Erect, branching, rough-hairy. The 3 leaflets of each leaf are obovate; those of the top leaves, which are stalkless are toothed nearly the whole length. The mode of flowering is a leafy, rather close cyme of yellow flowers. The seeds are grouped together on the receptacle, which is long, thin and downy.

The seed (Plate 74, fig. 45) when ripe is leather-brown, dull, about $1 / 30$ of an inch long, bluntly comma-shaped, with curved branching veins running longitudinally. Commonly found in timothy seed.

Time of flowering: June-July; seeds ripe July to September.

Propagation: By seeds.

Occurrence: Widely distributed throughout Canada.

Injury: A weed of secondary importance, common in old meadows and worn-out sandy soils.

Remedy: Repeated close cutting will keep it in check in waste places. It will not long give trouble on land worked under a short rotation of crops, including clover and hoed crops once every four years. Good drainage and enrichment of the soil will stimulate a more vigorous growth of cultivated crops and choke out this weed.

ALLIED SPECIES: The genus Potentilla is widely distributed, comprising many species closely related to the Upright Cinquefoil, as Potentilla monspeliensis L., var. norvegica (L.) Rydb., also commonly called Upright or Rough Cinquefoil. It is distinguished by less hairyness and by somewhat more narrowly oblong leaves. Both occur in similar situations and have about the same distributive range.

The seeds of the cinquefoils are very similar and their identification is sometimes difficult. They vary only slightly 


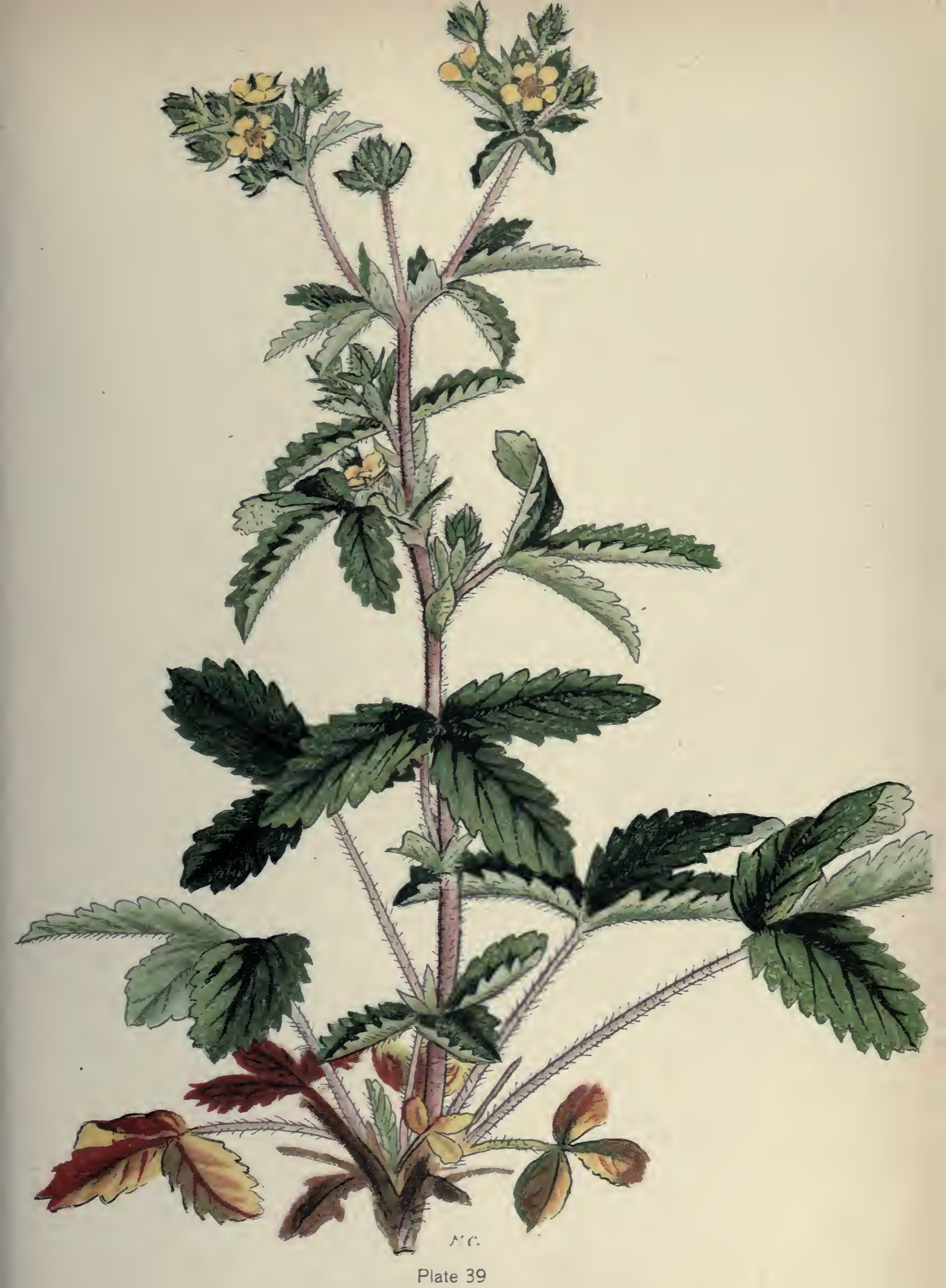

UPRIGHT OR ROUGH CINQUEFOIL

(Potentilla monspeliensis $L$.) 
in size and in the roughness of the net-like veins covering the surface, which sometimes are not apparent, especially when the seeds are not quite ripe.

Silverweed (Potentilla Anserina L.), occasionally mis-named Buttercup, is sometimes found in moist land. It is a perennial with slender, jointed runners, which root and form new plants at each joint like the strawberry. The leaves, silvery hairy beneath, are composed of from 3 to 10 large, oval, sharply-toothed leaflets on each side of the stalk, with very small ones between them. The long-stalked, golden-yellow flowers, nearly an inch across, are followed by a cluster of dry, smooth seeds. Silverweed roots on the surface of the ground and is best controlled by draining the land and plowing down the plants.

\section{THE PEA FAMILY (Leguminosae).}

This large and important family is well represented in Canada and contains many useful plants, such as peas, beans and clovers, as well as some poisonous species, as the Loco Weeds (Oxytropis) and Golden Bean (Thermopsis) of the western plains, and a small number of weeds of secondary importance. All plants of the Pea family collect nitrogen from the air and render it available for plant food.

Every species of this family can be recognized by one of two characteristics; either a butterfly-shaped corolla, such as we find on a large scale in the sweet pea, or a pod, technically called a legume, for a fruit, like that of the same plant or of the garden pea. By far the larger number of the plants have both characteristics.

Rabbit's-foot Clover (Trifolium arvense L.) is a useless member of this family, not common in Canada and of little importance.

The Sweet Clovers (Melilotus alba Desr.and Melilotus officinalis (L.) Lam.), often complained of by farmers, are biennial wayside weeds which are easily subdued by preventing them from seeding, as each plant lives for two years only. 
Black Medick (Medicago lupulina L.), also called Yellow Trefoil, is a useful pasture forage plant and in Europe the seed is frequently sown with mixtures of pasture grasses. The seed is common in clover seeds. It is sometimes mixed with alfalfa and red elover seeds as an adulterant when the latter are high in price. Mixed with red elover or alsike it should be treated as a weed, inasmuch as the plant matures earlier and the stems are hard and woody when the clover is ready to cut for hay. It has little value except as a pasture plant.

The seed-pods of a few members of the Pea family develop into burs and stick to wool, as, for instance, the Spotted and Toothed Medicks (Medicago arabica Huds. and Medicago hispida Gaertn.), neither of which, however, has established itself firmly in Canada. The only plant of the Pea family giving trouble in this way is Wild Liquorice (Glycyrrhiza lepidota (Nutt.) Pursh) which occurs on the prairies.

Loco Weed (Oxytropis Lamberti Pursh.) differs from the Milk Vetches (Astragalus) of the western plains in that the keel of the flower is tipped with a sharp-pointed appendage. All varieties of Loco Weed are common on the plains of Alberta and Saskatchewan and are believed to be the eause of a peculiar mental disorder among horses and eattle.

\section{WILD TARE (Vicia angustifolia (L.) Reichard)}

Other English names: Wild Pea, Wild Veteh.

Introdueed from Europe. Annual, hairless or downy. Stem slender, simple or branched at the base. Leaves are composed of 2-5, rarely 6, pairs of linear or lanee-shaped leaflets. Flowers $1 / 2$ to $3 / 4$ inch long, purple, 1 or 2 in the upper axils of the leaves. Pods black and linear, with the tips sharp and turned upwards, 2 inches long, 4 to 12 -seeded.

The seed (Plate 74 , fig. 48 ) is round, ranging from $1 / 10$ to $1 / 6$ of an inch in diameter, velvety black or olive brown, mottled with white and dotted with fine black spots; the whitish scar 


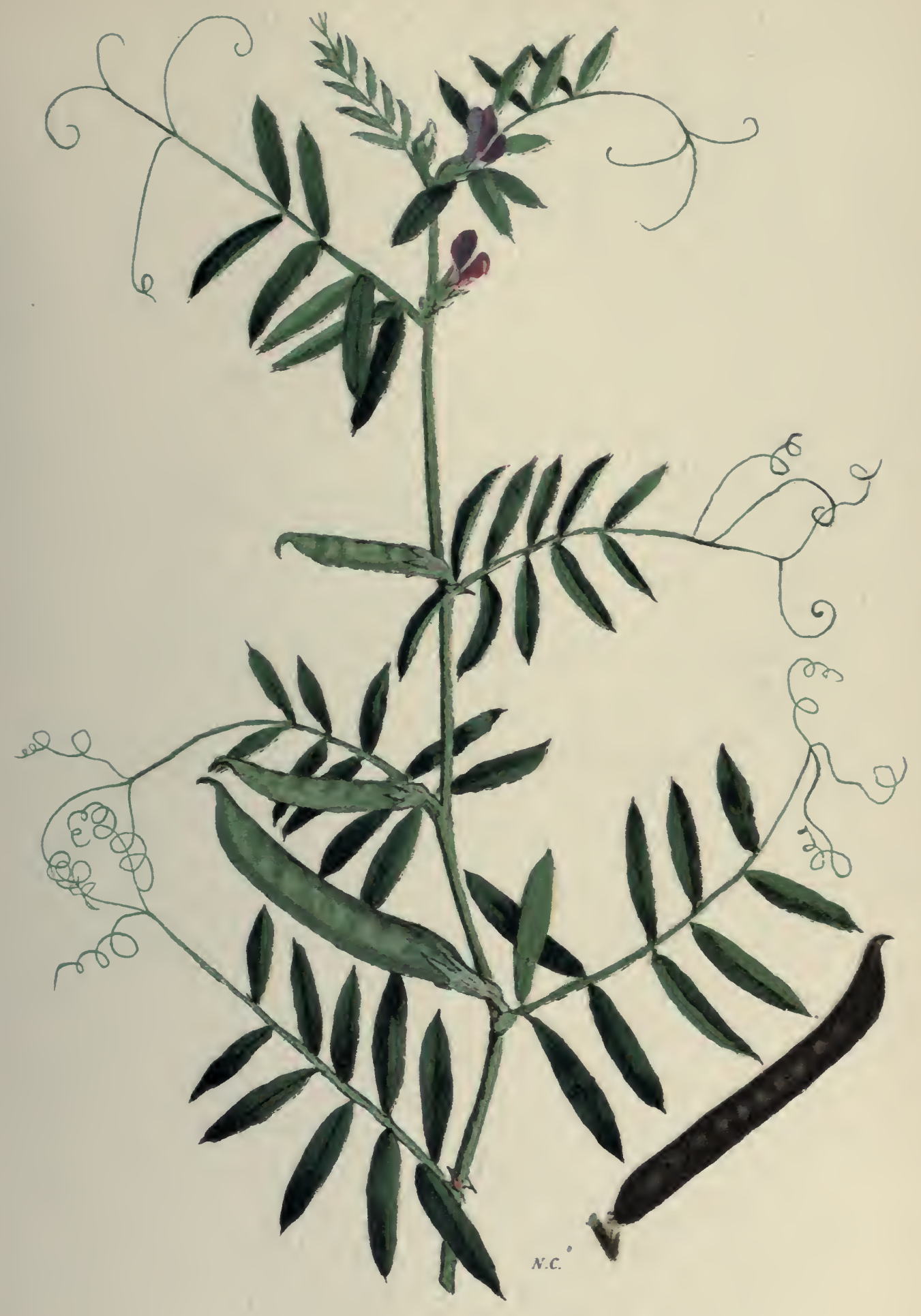

Piate 40

COMMON VETCH OR WILD TARE

(Vicia angustifolia /, rimcharn) 

about $1 / 5$ of the circumference of the seed in length, thin, threadlike.

Time of flowering: June to August; seeds ripe by August.

Propagation: By seeds.

Occurrence: Widely distributed in cereal crops and as a wayside weed throughout eastern Canada.

Injury: When present in quantity, Wild Tares materially reduce the yield of grain; they sometimes mat the crop by twining about the stems of the grain and make it more likely to lodge. It is often difficult to operate self-binders in grain crops matted with this weed. The seeds are exceedingly common in grain and are especially objectionable in oats required for milling.

Remedy: Sow clean seed grain. Adopt a short rotation of crops, including early maturing barley rather than oats, on lands where this weed is prevalent. Cultivate bare stubble directly after harvest, to stimulate germination of seeds, and pasture off the crop so produced. Badly infested fields may be seeded to grass for three or four years, but this will be found necessary only when a crop rotation, to prevent it from seeding, can not be followed.

ALLIED SPECIES: Cultivated Tare or Spring Vetch (Vicia sativa L.), so valuable for fodder and known to some farmers as Vetches or Fitches, somewhat resembles Wild Tare, but has much larger leaves and flowers $3 / 4-1 \frac{1}{1}$ inches long, with brown pods, and does not persist in the land when sown. The seed is nearly $1 / 4$ inch in diameter, generally plain black, the threadlike scar running about $1 / 4$ the circumference or the seed.

Purple Tufted Vetch (Vicia Cracca L.) is a persistent perennial rather difficult to get out of old meadows, but it produces a large crop of rich fodder which is rather beneficial than otherwise in hay. The seed is similar to that of Wild Tare but the scar is much broader and longer, about $1 / 3$ to $1 / 2$ the circumference of the seed. 
Hairy or Winter Vetch (Vicia Villosa Roth.) is a cultivated variety, the seed of which closely resembles that of spring vetch.

The seeds of the above mentioned species are often difficult to identify, owing to their great variation in size, shape and colour. They are common in eereal grain.

\section{THE SPURGE FAMILY (Euphorbiaceae).}

This family belongs to the flora of tropical and temperate climates and is widely distributed as herbs, shrubs and trees. Those common in Canada are prineipally low, prostrate weeds, mostly introduced and naturalized. The abundant, milky, acrid juice they contain is a characteristic of the family. This juice acts as an irritant and is poisonous. The plants are seldom attacked by insects or fungus growths.

Wax-ball or Three-seeded Mercury (Acalypha virginica L.), common in river flats and low fields in Ontario and eastward, belongs to this family. - It is a leafy plant, 1 to 2 feet high, with long-stalked, ovate leaves. It gives trouble in pastures, meadows and fields. On account of its acrid juice it is avoided by live stock and entails considerable waste wherever it occurs. The seed is about $1 / 16$ inch long, yellowish-gray, ovoid in outline, and comparatively soft, sometimes found in clover seeds. Clover fields should be rogued of this weed before the crop is harvested for seed.

Sun Spurge (Euphorbia Helioscopia L.), introduced, is an erect annual, abundant in eastern Canada. Mode of flowering, nearly flat-topped, umbrella-like, surrounded at the base with a whorl of stalkless, obovate, finely and thickly dentate leaves. Porl or capsule smooth and even, 3 -lobed.

The seed (Plate 74, fig. 49) at first sight somewhat resembles the nutlets of plants of the Mint family, or, better, the pods of Ball Mustard in miniature. When examined closely, however, it is easily recognized. It is rounded-oval in outline, rolling freely on a smooth surface, a little flattened on one face, with a sharp central ridge running to the apex. The sides of the seed not angled, as in those of the Mint family, the whole surface coarsely netted; scar kidney-shaped, white and very conspicuous. 
Sun Spurge is a common weed in gardens and waste places. Cultivated in Europe for decoration. Most troublesome on light, sandy soils. The seeds are a frequent impurity in commercial seeds. Clear up waste places and seed to permanent grass. Hand-pull and hoe in gardens. Special care is required to prevent the ripening of seed late in the summer. It will not long trouble lands worked under a short rotation with clean cultivation.

Ridge-seeded Spurge (Euphorbia glypto-sperma Engelm) is an erect, spreading, hairless, annual plant, with linearoblong leaves and sharply four-angled seeds; common on gravelly soils in fields and waste places in Ontario and locally in the Prairie Provinces and British Columbia.

Milk Purslane (Euphorbia maculata L.) is abundant along railways or waste places and in cultivated fields in Ontario and occasionally westward. It is a prostrate plant with minutely downy stems, linear-oblong leaves, pods acutely angled, seeds gray, small, sharply four-angled, with four shallow grooves across each concave side.

Flowering Spurge (Euphorbia corollata L.) is common on dry, sandy soils in western Ontario. Erect, with deep rootstocks, hairless or sparingly hairy. This plant may be distinguished by the showy white appendages, like corolla divisions, of the forked umbrella-like flowering clusters.

\section{THE MALLOW FAMILY (Malvaceae).}

This family is represented by a relatively small number of species of herbs and shrubs. Two species deserve mention as weeds of secondary importance.

Spiny Sida (Sida spinosa I.) is a profusely branched herb, about 1 foot high, covered with soft hairs. Leaves oblong or egg-shaped on long footstalks, dentate, with sharp teeth pointing forward. Flowers greenish-yellow, small and shaped like those of the hollyhock.

Round-leaved Mallow, Common Mallow or Cheeses (Malva rotundifolia L.) is a common garden weed, well known by its round, scalloped leaves, white and pink flowers and the arrangement of the seeds in the form of a cheese. The seeds are unusually long-lived. 


\section{THE ST. JOHN'S-WORT FAMILY (Hypericaceae).}

Herbs and shrubs of some 200 species, widely distributed over the northern hemisphere, mostly in warm climates, represent this family. The leaves are opposite, without teeth or divisions, oblong or lance-shaped, dotted, usually stalkless. Flowers regular, with many divisions, terminal, solitary or disposed in single or compound cymes, commonly yellow. The common name, St. John's-wort, comes from the use of plants of that family in Europe as decoration on St. John's Day.

COMMON ST. JOHN'S-WORT (Hypericum perforatum L.)

Other English names: Amber, Penny-John, Rosin, Rose, Herb-John.

Introduced from Europe. Perennial by runners at the woody base of the erect, much-branched, somewhat 2-edged stem. Leaves opposite without teeth or divisions, elliptic or linear oblong, black-dotted along the margin like the corolla divisions. Flowers deep yellow, grouped into terminal, loose cymes.

The seeds (Plate 74, fig. 50) are borne in 3-celled, ovoid pods. They are about $1 / 25$ of an inch long, cylindrical, rounded at the ends, with a minute point. The surface is rough, pitted, a little shiny, dark brown to black in colour.

Time of flowering: June to September; seeds ripe by July.

Propagation: By seeds and rootstocks.

Occurrence: Common in pastures, old meadows and roadways, from Nova Scotia to Ontario.

Injury: This weed and some of its allied species are troublesome in fields and pasture lands.

Remedy: Close cutting several times during the summer will reduce it in pastures. An application of salt-a small 


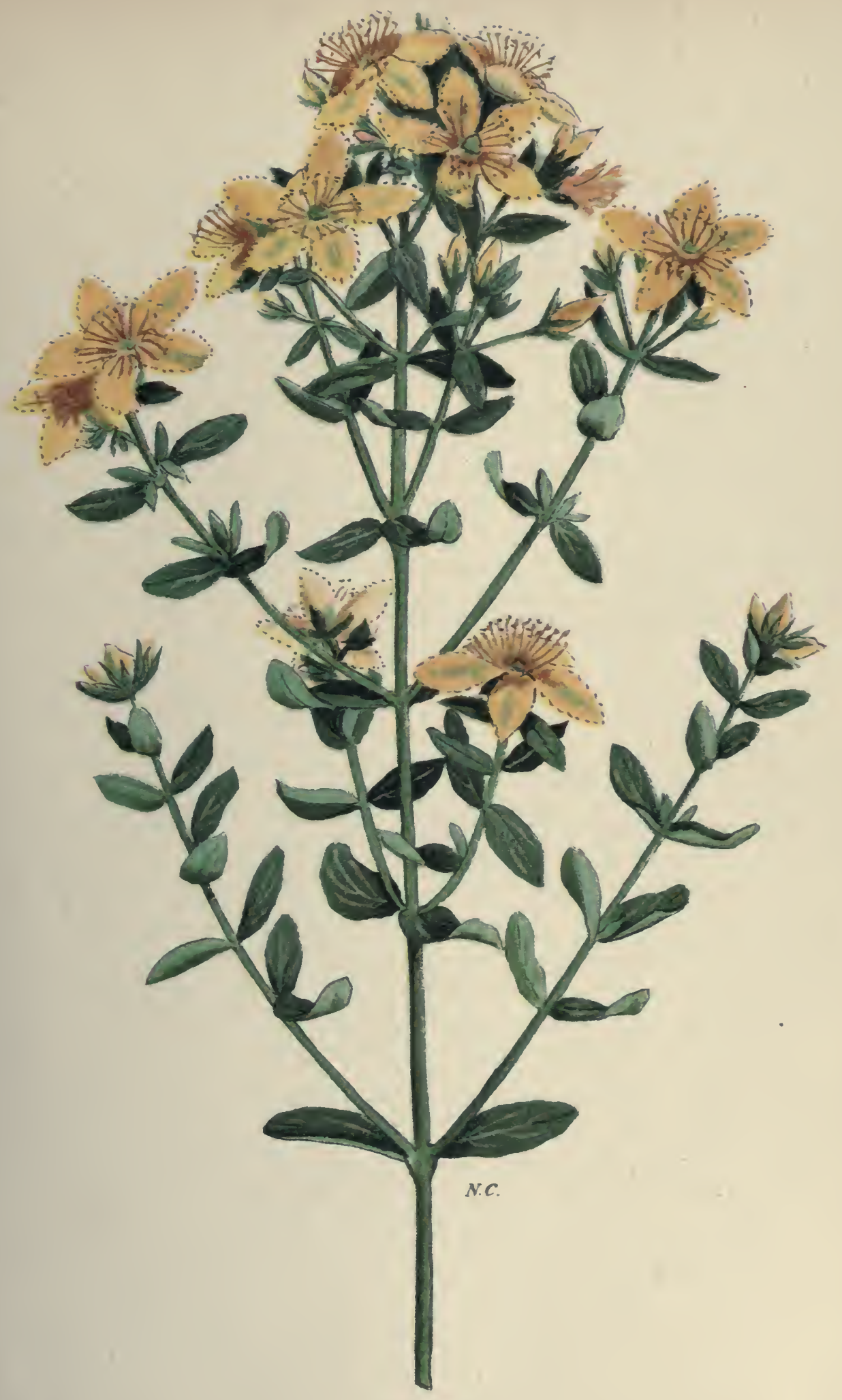

Plate 41

COMMON ST. JOHN'S-WORT

(Hypericum perforatum $L$ ) 

handful to each plant after close cutting in hot dry weatherwill kill it and may be practicable where the pest is not abundant and the land can not be brought under cultivation. Prevent it from going to seed. St. John's-wort is easily suppressed on land that can be cultivated under a systematic rotation of crops. Where it is established, it would be well not to seed to grass until it is suppressed.

ALLIED SPECIES: Great St. John's-wort (Hypericum Ascyron L.) is a common, coarse-growing weed in low rich soils and about swamps in Quebec and Ontario, occasionally occurring in old meadows and pastures along river flats.

Spotted or Corymbed St. John's-wort (Hypericum punctatum Lam.), about 2 feet in height, is abundant in the Bruce peninsula of Lake Huron, and quite general throughout Ontario, Quebec and eastward to Nova Scotia. Like the other named species, it frequently occurs in low meadows, much to the detriment of the hay.

Pale St. John's-wort (Hypericum ellipticum Hook.), with its bright yellow flowers, is common in Quebec, Northern Ontario, and westward to Lake Winnipeg.

\section{THE EVENING PRIMROSE FAMILY}

(Onagraceae).

A few weeds belong to this family and also many showy flowering plants, such as the fuchsias, clarkias and evening-primroses. A few kinds of Willow-herbs (Epilobium), also known as Fireweeds, are noticeable as weeds. The kinds most common in cultivated lands are Great Willow-herb or Fireweed (Epilobium angustifolium L.) and Sticky Fireweed (Epilobium adenocaulon Haussk.). These are rather persistent on wet land, the latter from its running perennial rootstocks and the former chiefly from the great number of downy seeds it produces. Of the Evening Primroses, two species require mention, White Evening Primrose and Common Evening Primrose. 


\section{WHITE EVENING PRIMROSE (Oenothera pallida Lindl.)}

Other English name: White-stemmed Evening Primrose.

Other Latin names: Oenothera albicaulis Nutt. and Canadian authors; Anogra pallida (Lindl.) Britton.

Native. Perennial. Roots white and fleshy, wide-spreading and throwing up flowering stems at intervals, thus forming large patches. Stems mostly simple, shining white, sparsely downy above, erect or nearly so, about 3 feet high. Leaves from 1 to 4 inches long, narrow and waved, sometimes pinnatifid but usually without teeth or divisions in plants found in the West. Flowers axillary, large and handsome, $1 \frac{1}{2}$ inches across, waxy-white, turning pinkish as they fade, open in day time, odour unpleasant. Tips of the calyx divisions at the ends of the buds free, as 4 little points. Capsules narrow and curved, 4 -angled, about 1 inch long with the seeds in single rows in each of the 4 cells.

The seed (Plate 74 , fig. 52) is about $1 / 16$ of an inch long, normally spindle-shaped but angular and somewhat twisted by compression in the pod, smooth and mucilaginous when soaked, yellowish-brown; under the microscope minutely dotted with black and faintly striate lengthwise.

Time of flowering: July-August; seeds ripe in September.

Propagation: By seeds and extensive deep-running fleshy rootstocks, every part of which when broken will throw out shoots and form new plants.

Occurrence: Manitoba and westward to British Columbia.

Injury: This deep-rooted perennial is very persistent in sandy land.

Remedy: Summer-fallow with deep or shallow plowing, according to the nature of the soil, after the growth has been made in summer. Cultivate in fall or in spring before seeding to a crop. 


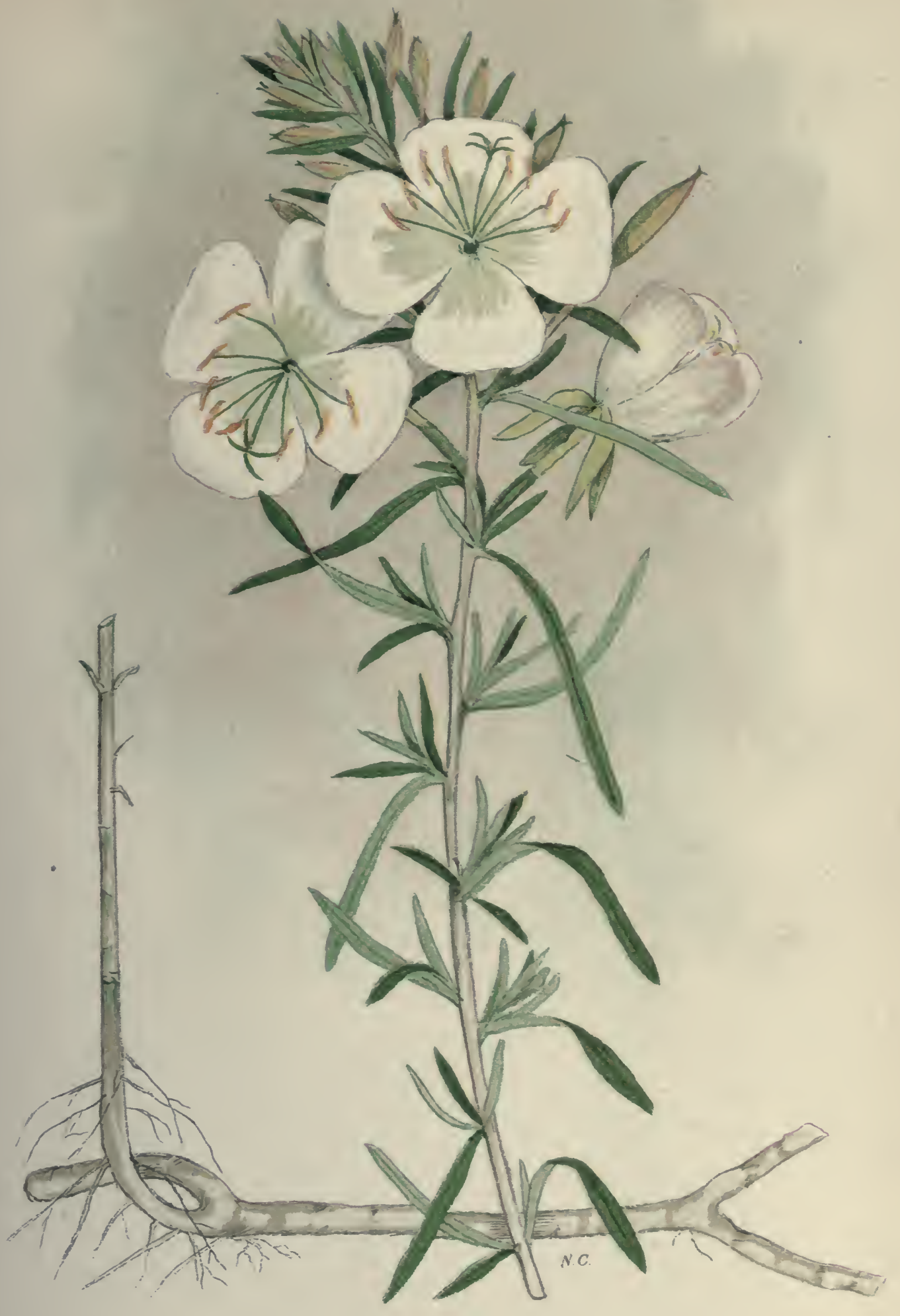

Plate 42

WHITE EVENING-PRIMROSE

(Oenothera pallida Lindl) 

ALLIED SPECIES: Common Evening Primrose (Oenothera biennis L.) is a tall, coarse biennial which occurs throughout the country and is easily recognized by its tall, branching habit (4 ft. by $3 \mathrm{ft}$.), its soft, downy, lance-shaped leaves, and its large, showy, yellow flowers which open in the evening.

The seeds (Plate 74, fig. 51) are frequent in clover seed. They are produced in large numbers in long, tapering, 4-celled capsules, 2 rows of seed in each cell, which are clustered all along the stems. They are about $1 / 16$ of an inch long, dark reddish-brown, and with a roughened surface much angled by compression in the pods.

Common Evening Primrose makes only a rosette of leaves the first year. For this reason it appears only in crops sown in autumn or on stubble. In thin clover fields it sometimes occurs conspicuously and should be either spudded out or cut off below the crown in the first season; or the tall flowering plants should be cut off below the surface and pulled out before the seeds ripen. On stubble land to be sown to grain, the rosette-like plants should be destroyed by fall or spring cultivation. As the pods do not easily shed their seeds and the plants are at all times conspicuous, much contamination of clover seed may be prevented by a little care at harvest time.

\section{THE PARSLEY FAMILY (Umbelliferae).}

This family contains many herbaceous plants of weedy appearance, seldom of much floral beauty, but important as food, either for their large succulent roots, as carrot and parsnip or for their fleshy leaf stalks, as celery. The seeds of many are aromatic and wholesome, as caraway and coriander. Many, like cowbane and hemlock, contain virulent poisons. The leaves are mostly pinnatifid, repeatedly sub-divided, and the flowers are borne in mostly flat-topped, umbrella-like clusters, more or less compound. The corolla has 5 divisions, often unequal in size. 
The fruit when ripe, separates into 2 seed-like halves, commonly called seeds, each having 5 main or primary ribs rumning lengthwise, which, in the different plants, are modified into wings or rows of bristles or prickles, of great value in distinguishing the species; sometimes there are 4 secondary or intermediate ribs. The corky coat of the "seeds" bears several longitudinal cavities filled with resinous or oily substances, which give them their characteristic odours and flavours. The true seed is inside the fruit and is tasteless.

Nearly all the wild forms of the Parsley family are noxious weeds from the fact that they harbour insect and fungus pests that attack celery, parsnips and carrots.

\section{SPOTTED COWBANE (Cicuta maculata L.)}

Other Fnglish names: Cowbane, Water Hemlock, Musquash Root, Beaver Poison, also wrongly ealled Water "Parsnip."

Other Latin name: Cicuta virosa var. maculata Coult \& Rose.

Native. Perennial. Stems stout, erect, hollow and jointed, widely branching, 3 to 6 feet high, quite smooth, pale green, dotted and streaked with purple. Root, a bundle of a few fleshy, spindle-shaped tubers, like small parsnips. Leaves compound, in 2 or 3 divisions, elasping by an expanded base, the lower on long footstalks, the upper stalkless. The leaflets lance-shaped deeply toothed. Flowers small, white, in compound, umbrella-like clusters 1 to 4 inches across; the little footstalks of the many flowered secondary clusters unerual, from 1 to 2 inches long.

The seed (Plate 74, fig. 53) 1/12 of an inch long, smooth, ovate, compressed on the sides, separating into boat-shaped, ribbed halves. When eut across, the seed shows 4 oil tubes between the ribs and 2 on the flat side.

Time of flowering : July-August; seerls ripe AugustSepteinber.

Propagation: Copiously by seeds and by offsets from the erown of the root at the base of the old stem. 

Occurrence: In low land along waterways, probably right across the Dominion.

Injury: Roots intensely poisonous to stock, particularly cattle, which pull them out and eat them freely when grazing in spring. The roots look like small parsnips and, like them, have a strong aromatic odour, which seems to make them attractive to stock. It is claimed that the flowering plants, when cut with hay, may be eaten by animals without any ill effects, but that the seed-bearing plants are dangerous. The whole plant, however, contains some of the poisonous principle, although it is true that this is most abundant in the roots and the seeds. Consequently $n o$ hay containing Spotted Cowbane or other Water Hemlocks (also ealled Water "Parsnips") should be fed.

This plant-and in the West probably two or three allied species closely resembling it, Oregon Water Hemlock (Cicuta vagans Greene), Purple-stemmed Water Hemlock (Cicuta Douglasii C. \& R.) and Wyoming Water Hemlock (Cicuta occidentalis Greene) - is the cause of many deaths in spring among cattle, and unfortunately, in cases where much of the plant has been eaten, no remedy can be applied. On the plains, when mild cases are discovered in time, two or three daily doses of lard or bacon grease are administered, but it is seldom that anything can be done, on account of the intense virulence and quick action of the poison. A piece of the root of Oregon Water Hemlock, about the size of a walnut, is said by Prof. Hedrick, to be sufficient to kill a cow in about fifteen minutes.

Remedy: From the nature of the localities where Water Hemlock grows, hand-pulling is the best treatment for this dangerous weed. This is easily done, particularly if the roots are first loosened with a spud or some other implement. The plants should be carefully piled up to dry and then burnt or otherwise destroyed. The poisonous principle, called cicutoxin, is of a resinous or oily nature and will contaminate water, if, as is sometimes done, the pulled-up plants are thrown into sloughs where they may be trampled upon by stock. It is 
important that stockmen should be able to recognize these plants, so as to destroy them whenever seen, or else to keep their animals away from localities where they grow too abundantly to be pulled out by hand.

ALLIED SPFCIES: Caraway (Carum carvi L.) has escaped from gardens and become a troublesome weed in many places. The roots are thick and fleshy and the whole plant bears a strong resemblance to Wild Carrot. It is frequently prevalent in waste places about gardens.

Wild Parsnip (Pastinaca sativa L.) is a weed that is believed to have escaped from cultivation; it is common about gardens and old dwellings throughout eastern Canada. In appearance it is not dissimilar to the cultivated kinds. The root is poisonous and should be exterminated. If not spread over large areas, the plant may be destroyed by applying a small handful of salt to the root after the top is closely cut in hot dry weather. It will not long survive continued thorough cultivation.

Wild Carrot (Daucus Carota L.) is an objectionable weed along roadsides, waste places, old meadows, and occasionally gives trouble in cultivated fields, though not on land under regular rotation of crops. Old meadows infested with it should be broken up and cultivated for a few years. Sheep will suppress it in pasture lands. The cultivated carrot probably originated from this wild plant.

The seed (Plate 74, fig. 54) is characteristic of the family. The main or primary ribs are inconspicuous while the secondary ones are prominent, winged and armed with long prickles, which, however, are easily rubbed off. Occasional in commercial grass and clover seeds; most common in imported stocks.

Idle weeds are fast in growth. 


\section{THE MILKWEED FAMILY (Asclepiadaceae).}

Milkweeds or Silkweeds are widely distributed throughout North America and are best known by their milky juice, opposite or whorled leaves, and flat-topped clusters of showy flowers. They are persistent perennials in waste places and are difficult to suppress in cultivated land.

Butterfly Weed or Pleurisy-root (Asclepias tuberosa L.) grows from 2 to 3 feet high from long horizontal roots. The whole plant is roughish-hairy and very leafy. The leaves are oblong-ovate, stalkless or with very short footstalks. A showy plant with orange flowers. Abundant in Ontario.

Swamp Milkweed (Asclepias incarnata L.) grows in marshes and ditches from the Atlantic Coast westward to Saskatchewan. About 5 feet high, very leafy, but smooth and with rose-purple or flesh-coloured flowers.

Common Milkweed or Silkweed (Asclepias syriaca L.) is abundant on roadsides, in waste places, pastures and fields from New Brunswick to Saskatchewan. It is taller than the preceding species, covered with soft, fine hairs; leaves oval, pale underneath. The flowers are deep purple to whitish, flower clusters often nodding. This perennial weed spreads by its broad, winged seeds and by its deep, thick, fleshy, persistent rootstocks. Repeated cutting when in flower, continued from year to year, will suppress it. Salt applied to individual plants after cutting in hot dry weather is said to be efficacious. Deep plowing and thorough cultivation with short rotation of crops will eradicate it from fields.

There be Plants that have Milk in them when they are cut; as Figs, Old Lettuce, Sow-thistles, Spurge, etc. The cause may be an inception of Putrefaction: For those Milks have all an Acrimony, though one would think they should be Lenitive. . Lettuce is thought Poysonous, when it is so old as to have Milk, Spurge a kind of poyson in it self; and as for Sow-Thistles, though Coneys eat them, yet sheep and Cattle will not touch them; and besides, the Milk of them, rubbed upon Warts, in short time weareth them away: Which showeth the $M i l k$ of them to be Corrosive. IVe see also, that Wheat and other Corn sown, if you take them forth of the Ground, before they sprout, are full of Milk; and the beginning of Germination is ever a kind of Putrefaction of the Seed. Euphobrium also hath a Milk, though not very white, which is of great Acrimony. And Saladine hath a yellow $M$ ilk, which hath likewise much Acrimony, for it cleanseth the Eyes, it is good also for Cataracts. 


\section{THE MORNING GLORY or CONVOLVULUS FAMILY (Convolvulaceae).}

The plants of this family possess characteristics by which they are easily recognized: i.e., the twining stems, the trumpetshaped flowers, and the fruits which are spherical cartilaginous capsules with distinct divisions. The three following species of Morning Glory are classed as weeds, besides a few varieties of Dodders which are closely allied to them and represent the only genus of the tribe Cuscuteae. These are curious, annual, leafless parasites, occurring as loose, tangled masses of fleshy threads, with clusters of flowers or small, round pods at short intervals, attached to various plants from which they draw their nourishment.

\section{FIELD BINDWEED (Convolvulus arvensis L.)}

Other English names: Bindweed, Small Bindweed, European Bindweed, Small-flowered Morning Glory.

Introduced from Europe. Perennial, deep-rooting, with extensive, creeping, cord-like, fleshy rootstocks; these throw up numerous slender branching and twining smooth stems, which form thick mats on the surface of the land and twist around any plants growing within reach, using them as supports and choking them out. Leaves about 1 to $1 \frac{1}{2}$-inches long on slender stalks, ovate or heart-shaped, arrow-shaped at base. Flower-stalks slender, about the same length as the leaves, provided with miniature leaves at some distance below the large, open, funnel-shaped, pink flowers, which are over an inch across. Fruit a round cartilaginous, 2-celled capsule, containing 3 to 4 seeds.

The seed (Plate 74, fig. 55) is rather large, 1/6 of an inch long, dark brown, pear-shaped; one face convex, the other bluntly angled with flat sides. Surface roughened with small tubercles; 


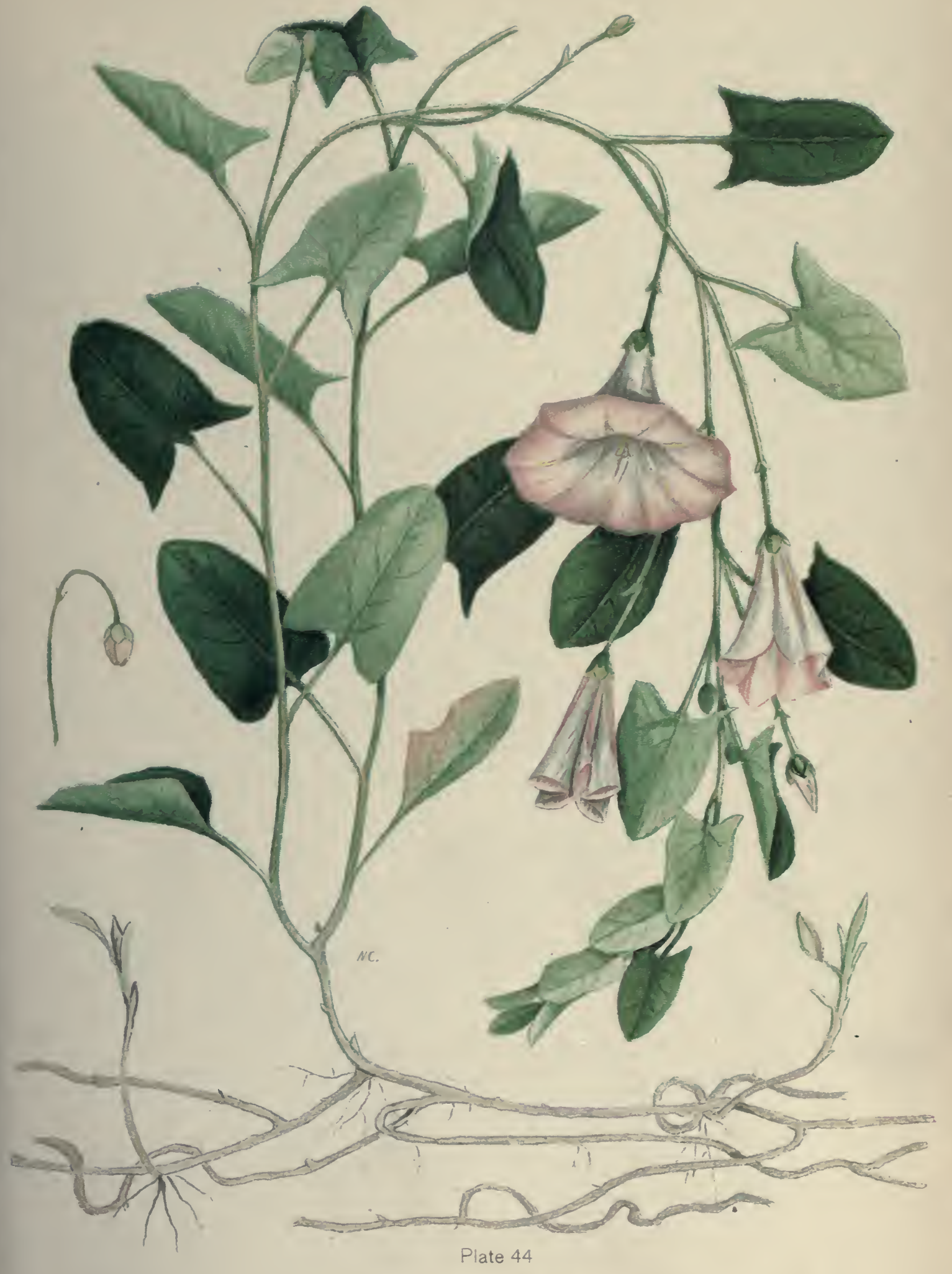

FIELD BINDWEED

(Convolvulus arvensis L.) 

the basal scar is a roughly lined, reddish depression at the lower pointed end. Germ much folded and crumpled inside the seed.

Time of flowering: From June throughout the summer; seeds ripe by August.

Propagation: By seeds and running rootstocks, every portion of which will produce a new plant if broken up by the plow. In many localities, as at Ottawa, this plant produces few seeds. It has, however, everywhere a most persistent habit of growth.

Occurrence: Although widespread throughout the Dominion and in restricted localities very troublesome, Field Bindweed, fortunately, can not as yet be called a common weed of Canada.

Injury: Exceedingly hard to eradicate, from its almost incredible persistence, owing to the vitality of the fleshy rootstocks.

Remedy: A short rotation of crops should be practiced, including late sown roots or other cultivated crops; rape is useful for this purpose. Frequent use of a broad-shared cultivator will destroy new growths and exhaust the vitality of the plants. Sow no crop seeds containing those of Field Bindweed. Applications of salt or lime, sometimes recommended to kill this weed, are useless unless applied in large quantities.

ALLIED SPECIES: Upright Bindweed (Convolvulus spithamaeus L.) is occasionally complained of in sandy land. Hedge or Great Bindweed (Convolvulus sepium L. and varieties) sometimes give trouble for a year or two after land is broken in the Prairie Provinces.

Convolvulus will next in boundless Stores, Cloath the moist vale with yet unfinish'd Flow'rs; These rude Essays were first for Lilly's meant, When Nature on a nobler work intent, First took the pencil and began to paint. 


\section{CLOVER DODDER (Cuscuta Epithymum Murr.)}

Other English names: Love Vine, Lesser or Thyme Dodcler. Other Latin name: Cuscuta Trifolii Bab.

Introduced from Europe. An annual with slender yellowish - and reddish stems, which twine about the host plant and become attached to the clover stems by suckers through which the parasite obtains nourishment from the host. The plant appears to be leafless, the leaves being reduced to small scales. Flowers whitish or pinkish, in clusters along the threacl-like, twining stems.

The seed (Plate 74, fig. 56) is small, from $1 / 30$ to $1 / 20$ of an inch in diameter, yellow or brown, irregularly splerical, and more or less angled on the inner scar-bearing side; the surface granular-roughened. When soakerl, the germ is seen to be spirally coiled, wormlike.

Time of flowering: July to November; seeds ripe by September, when they fall to the ground and germinate the following spring.

Propagation: By seeds.

Occurrence: The abundant occurrence of Dodder seeds among imported alfalfa and clover seeds offered for sale cluring recent years, as well as the presence of the plant in some fields of alfalfa in Ontario, has aroused much interest in these parasitic plants.

Injury: Dodeler spreads rapidly from a single plant. It will destroy quite large patches of clover, giving a field the appearance of having been burnt in irregular patches. There is probably no weed legislated against so much as Dodcler. It is a serious pest in southern Europe, parts of the United States, Chili, and other temperate to warm climates having long summer seasons without frost. During years of shortage in clover seed crop of Canada, it has frequently been introduced and 


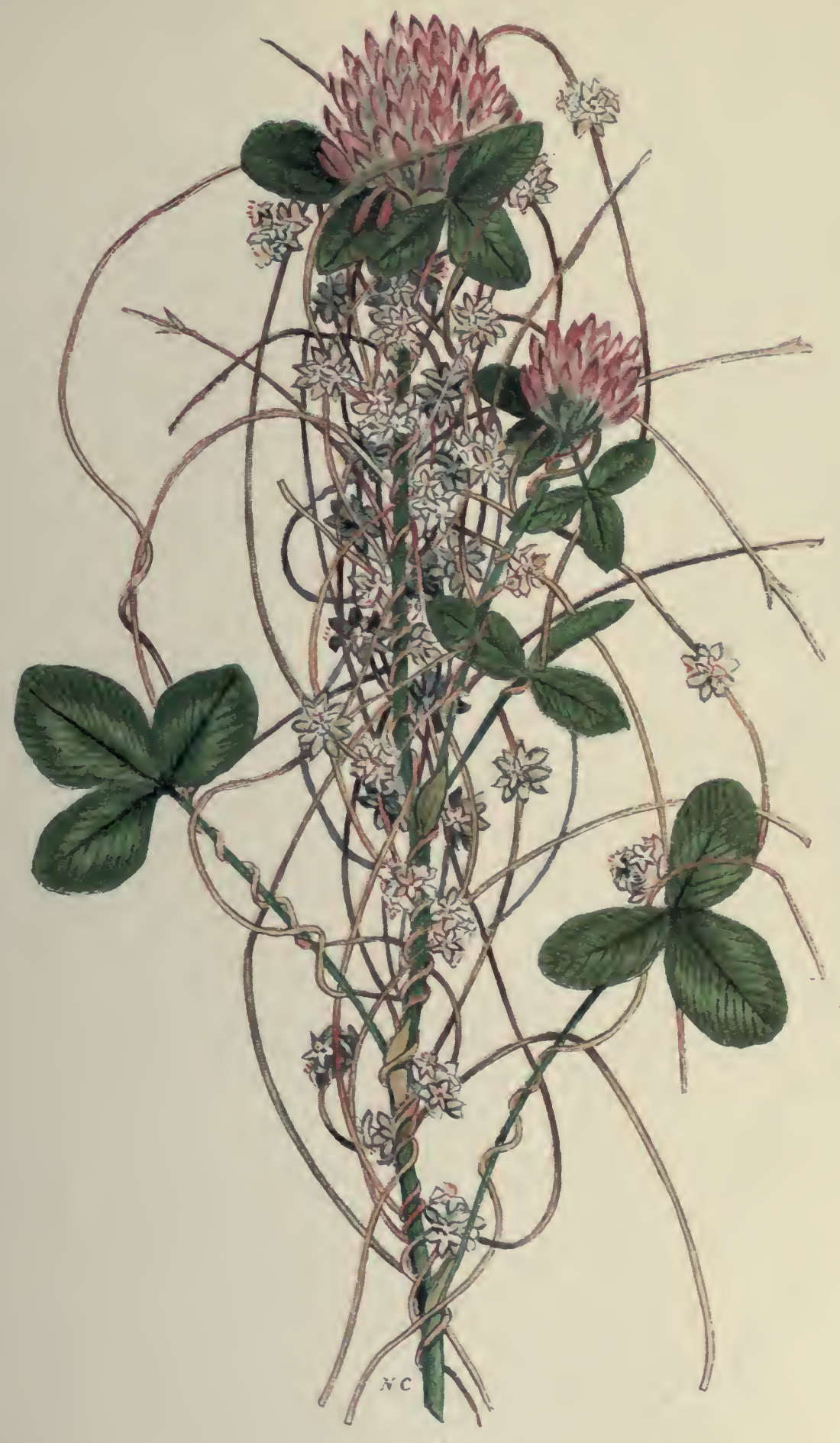

Plate 45

CLOVER DODDER

(Cuscura sp) 

widely distributed in imported seed, but its ravages have been noted on red clover only in a few instances, and those in southern Ontario and the Pacific Coast in years following an exceptionally late fall without frost until October.

Remedy: As soon as the pest is noticed, the infested patches should at once be mown with a scythe and the refuse removed and destroyed. Fields badly contaminated should be plowed before the seed has formed, or the crop cut early for hay and the land then plowed. Clover seed should never be taken from fields infested with this pest.

ALLIED SPECIES: Alfalfa Dodder (Cuscuta species) has given trouble in a few localities in southwestern Ontario, where it is krown to have continued in alfalfa for three years. This is believed to be a different species and earlier than the one which commonly gives trouble in red clover. Alfalfa affords a better opportunity for Dodder to mature its seeds, by which it continues in the crop from year to year. Alfalfa fields badly infested should be brought under cultivation. Dodder may be suppressed in small patches by repeated cutting which prevents it from seeding.

\section{THE BORAGE FAMILY (Boraginaceae).}

The plants of this family are chiefly rough or bristly-hairy herbs with erect, branching stems, alternate simple leaves, without any teeth or divisions, and tubular flowers with 5 corolla lobes and a 5-parted calyx, except in Blue Weed (Echium). The flowers are usually in 1-sided racemes, which, when young, are coiled spirally intrards at the tips but unroll and become nearly straight as the flowers open. The 4 hard 1 -seeded or 2 -seeded nutlets, which contain the true seed, may be rough or highly polished, downy or armed with barbed prickles. The basal scars on the nutlets furnish characteristics useful in identifying the various species in commercial seeds. 
The Borage family contains several weeds, as Hound's Tongue or Common Bur (Cynoglossum officinale L.), a leafy, downy, biennial wayside weed, with reddish purple flowers. The seeds (Plate 74, fig. 57) are barbed nutlets, obovate, about $1 / 4$ inch. long, the barbs more thinly spread over the flat and broad upper surface than on the more rounded scar-bearing surface and on the slight margin. The scar depressed, pearshaped, darker than the grayish brown nutlet. These burs are troublesome in the wool of sheep.

\section{BLUE BUR (Lappula echinata Gilibert)}

Other English names: Stickseed, Sheep Bur, Stickweed.

Other Latin names: Myosotis Lappula L.; Lappula Lappula (L.) Karst; Echinospermum Lappula Lehm.

Introduced from Europe. Annual and winter annual. Erect, branching, whole plant covered with short white hairs, which give it a grayish appearance. Leaves linear-oblong; root-leaves about 3 inches long, narrowed at hase; stem-leaves stalkless. Flowers small, about $1 / 8$ inch across, pale blue, erect, in leafy, more or less 1-sided racemes, and with minute bracts.

The seed (Plate 74, fig. 58) is about $1 / 8$ inch long, dark brown, pear-shaped, with a rough surface, inner face sharply angled, outer face rounded, without spines in the centre but having on the sides a double series of long stiff spines, each of which has at its apex a star of 3 or 4 sharp hooks. This nutlet is often found in clover and other commercial seeds, when many or all of the long harbed bristles may be rubbed off; but there is no trouble in recognizing it from the angled inner face, with the small basal scar at the bottom of the central ridge and the unarmed area on the outer face.

Time of flowering: From June; seeds ripe July.

Propagation: By seeds. 

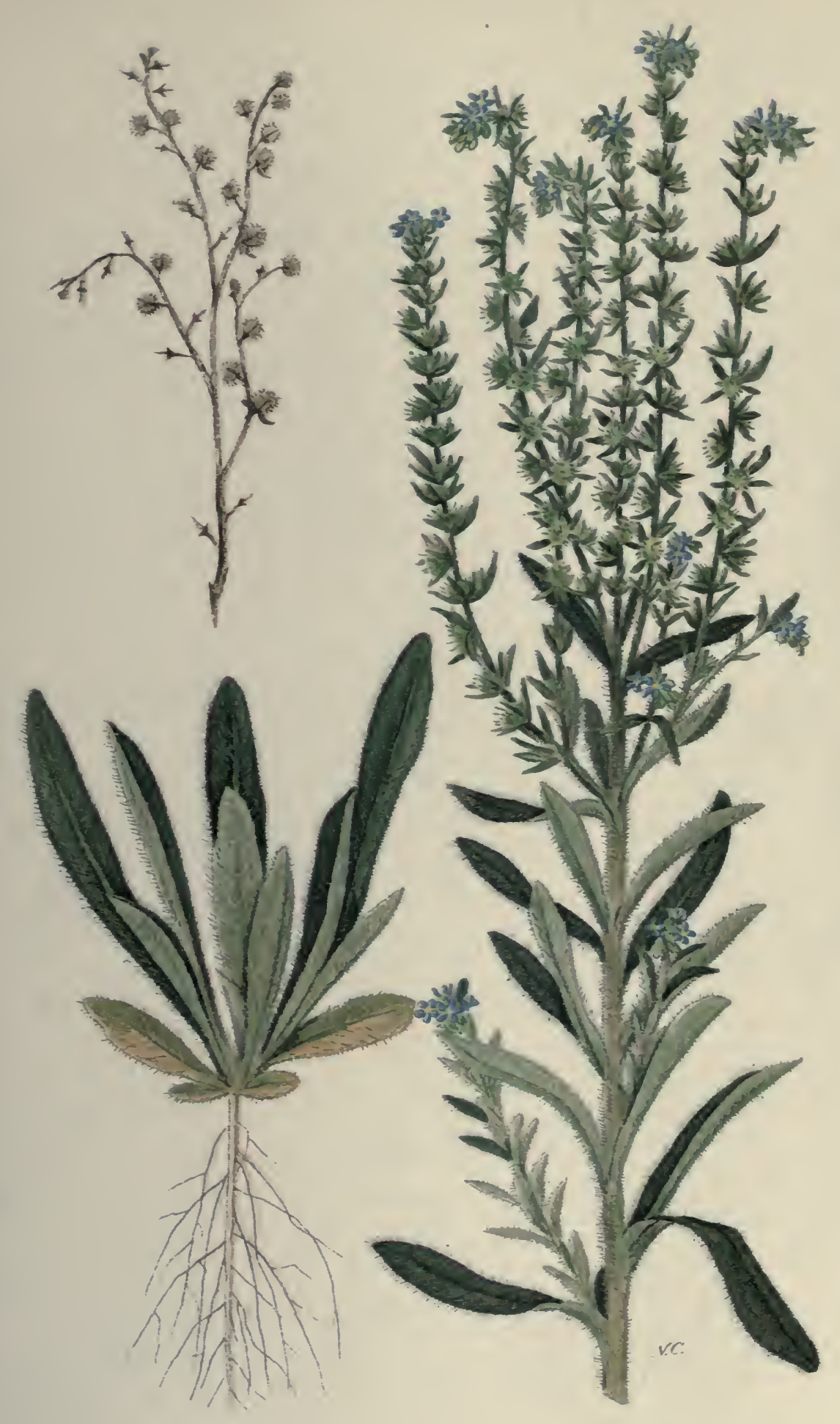

Plate 46

BLUE BUR OR STICKSEED

(Lappula echinara Guthert) 

Occurrence: By roadsides and in waste places in eastern Canada. In the West chiefly in corrals and around buildings but spreading into cultivated land, where it is sometimes abundant on fields left for summer-fallowing.

Injury: An objectionable weed in waste places, roadsides and open woodland pastures. Troublesome to sheep on account of the fleeces becoming matted by the burs. A pernicious weed in fields of grain sown on stubble lands in the Prairie Provinces. The plants have a disagreeable odour and are among the few weeds which sheep refuse to eat, although they have been observed to nip off the fresh flowers of this and other members of the same family.

Remedy: Sow clean seed. Badly infested fields should be summer-fallowed. Thorough spring cultivation with the disc or broad-shared cultivator or shallow plowing is necessary to prevent its abundant occurrence in crops sown on stubble lands. Handpull from clover crops. Close cutting when in early bloom will prevent it from seeding, and, if continued from year to year, will ultimately suppress it in pastures and waste places. Occasional plants should be hand-pulled.

ALLIED SPECIES : Virginian Stickseed (Lappula virginiana (L.) Greene) is quite widely distributed in eastern Canada. It is similar in appearance to common Blue Bur and equally objectionable.

\footnotetext{
Banks newly quicksetted, some weeding do craue, the kindlier nourishment, thereby for to haue: Then after a shewer, to weeding a snatch, more easily weed, with the root to dispatch.
}

-Thomas Tusser, Five Hundreth Pointes of Husbandrie, 1557.

Herbs of the colder sort die yearly both in Root and Stalk; as Lettice, Purslane; also Wheat and all kind of Corn: yet there are some cold Herbs which will last three or four years; as the Violet, Strawberry, Burnet, Primrose, and Sorrel. But Borage and Bugloss, which seem so alike when they are alive, differ in their deaths; for Borage will last but one year, Bugloss will last more. 


\section{BLUE WEED (Echium vulgare I.)} Devil.

Other English names: Viper's Bugloss, Blue-thistle, Blue

Introduced from Europe. Biennial, with a deep, black, taproot. Whole plant bristly hairy, red at the base of the stiff bristles on the stem. Flowering stems erect and wand-like, forming compound spikes of reddish buds and bright blue flowers, 1 to 2 feet high; the spikelets curved at the tips, as is usual in the Borage family. Root-leaves linear-oblong or linear-lanceshaped, narrowed at base, without teeth or divisions, bristly hairy above and below, 6 to 8 inches long, the first year forming dense rosettes of long leaves lying flat on the ground; leaves of the flowering stems stalkless. Flowers tubular-funnel form, not regular, with 5 rounded, spreading lobes; calyx of 5 narrow, bristly divisions.

The seeds (Plate 74, fig. 60), 4 from each flower, are $1 / 8$ inch long, dark brown, hard and rough, irregularly angular and cone-shaped, sharply angled on the inner face and rounded on the outer, with a keel running from the sharp apex half way down the outer convex face; basal scar a large, flat, triangular surface, acutely margined, marked with two little cone-like projections and a small, deep hole close to the inner angle.

Time of flowering: July to September; seed ripe by August.

Propagation : By seeds which are spread by dead plants blown by the wind in winter.

Occurrence: Common by roadsides and in waste places and fields throughout Ontario and the eastern provinces. Chiefly on limestone and gravelly or poor soil.

Injury: An abundant, coarse-growing weed, giving trouble in pasture lands that can not be brought under cultivation and in crops on land not worked under a regular rotation with thorough cultivation. - In sheep pastures it sometimes causes 

the wool to become matted. The seeds are common in clover and other commercial seeds.

Remedy: Continued close cutting from year to year when the plant is in early bloom will suppress it in waste places and pastures. Spudding below the crown of the root will kill it. The seeds are not long-lived in a moist climate and are not likely to produce plants after from three to five years. If the pest is prevented from seeding for three consecutive years, relatively few plants will require cutting thereafter; probably none after five years. This biennial will quickly succumb to a short rotation of crops with fall plowing and thorough spring cultivation before seeding.

ALLIED SPECIES: Pigeon Weed (Lithospermum arvense L.), also called Red Root, Wheat Thief and Field or Corn Gromwell, is abundant in western Ontario and troublesome in fields of fall wheat. It is a widely branching biennial or winter annual with white flowers and produces a large number of early-ripening seeds.

The seed (Plate 74, fig. 59) is similar in size and general shape to that of Blue Weed, but rather less angular and with a much smoother surface. Instead of having rough projections, it is deeply and irregularly grooved, with prominent ridges between the grooves. It may be easily recognized by the basal scar, which is oval or obtusely 3 to 5 -angled; instearl of the pit at the inner angle and the two cone-shaped projections on an excavated surface, it has a convex surface with two lightcoloured distinct cones. These seeds are common in poorlycleaned fall wheat and rye.

Land is best cleaned by a short rotation, including grain sown in spring instead of autumn. Plants which start growth in autumn can be destroyed by fall or spring plowing or discing.

The Buglosse groweth in all gardens, and in sandie champion countrys......it maketh men gladde and merie. 


\section{THE VERVAIN FAMILY (Verbenaceae).}

A family of mostly tropical plants, closely allied to the mints, represented in Canada by only a few weeds and many varieties of ornamental plants.

White Vervain (Verbena urticaefolia L.), probably introduced but indigenous in eastern Canada and common along roadsides, waste places and pasture lands, from New Brunswick to Ontario. It grows from 3 to 5 feet high, has white flowers in slender, branching clusters, and stalked, oval, acute leaves, coarsely dentate with sharp, forward-pointing teeth.

Narrow-leaved Vervain (Verbena angustifolia Michx.) is abundant on dry limestone soils in Quebec and Ontario. It is a low perennial with a deep root; roughish, narrowly lanceshaped leaves tapering at the base, stalkless; flowers in dense spikes, purple, and larger than those of Blue Vervain.

Blue Vervain (Verbena hastata L.) is the commonest weed of this family. It is a tall plant, from 4 to 6 feet in rich, moist soil; stem 4-angled and branched. Leaves stalked, lance-shaped, taper-pointed, with sharp, forward-pointing teeth. Flowers violet blue, small, borne in a cluster of spikes at the summit.

The seed (Plate 75, fig. 61) is brown except the large, whitish basal scar at the bottom of the inner face. The outer face is convex, irregularly ridged lengthwise and sharply angled at the sides. The inner face slopes to the margin from a sharplyangled central ridge. This seed is often found in timothy and other grass seeds.

Vervain is used in easting lots, telling fortunes, and foreshadowing future events by way of prophesie. Of all Hearbes there is none more honoured among the Romans than the sacred plant Vervaine. It is that hearbe our ambassadors use to carry witl then when they declare war, and to give defiance unto our enemies. With this hearbe the festivall table of Jupiter is wont to be swept and cleaned with great solemnitie, with it our houses also be rubbed and halloweed for to drive away ill spirits.... They report that if the dining roome be sprinkled with water in which the herbe hath been steeped the guests will be merrier. 


\section{THE MINT FAMILY (Labiatae).}

This large family contains several weeds, some of them of common occurrence but none of much importance in agriculture. The characteristics of the family are well marked and easily recognized. A noticeable feature is the production of pleasantly aromatic and oily secretions, as in the case of lavender, mint, peppermint, sage, thyme, rosemary, bergamot, patchouli, and many others, which are used in cooking or in the manufacture of perfumes. No plant in this large family is poisonous.

Salient characteristics of this family are: A square stem, often downy; a strong scent when bruised; leaves always opposite and simple; flowers generally clustered in the axils of the leaves; corolla irregular, more or less mouth-shaped, with large, wide-open lips, the lower of which is generally much the larger. The fruit of these plants consists of seed-like nutlets, generally partly keeled through compression, lying free at the bottom of the calyx. Few plants of the Mint family are troublesome enemies of the farmer on properly worked land, but the nutlets of some are often found in commercial seeds.

Many odde old wives fables are written of vervaine tending to witchcraft and sorcery, which you may reade elsewhere, for I am not willing to trouble your eares with reporting such trifles, as honest eares abhorre to heare.

-John Gerard, 1597.

The Rule is certain, That Plants for want of Culture, degenerate to be baser in the same kind; and some:imes so far as to change into another kind. 1. The standing long, and not being removed, maketh them degenerate. 2. Drought, unless the Earth of itself be moist, doth the like. 3. So doth removing into worse earth, or forebearing to compost the Earth; as we see, that Water Mint turneth into Field Mint, and the Colewort into Rape by neglect, etc. 


\section{HEMP NETTLE (Galeopsis Tetrahit L.)}

Other English names: Hemp Dead Nettle, Bee, Dog, Blind or Stinging Nettle, Nettle-wild or Bastard Hemp.

Introduced from Europe. Annual. 'Stem erect, tall, swollen below the joints, rough hairy. Leaves ovate, with strong, forward-pointing teeth, tapering at the end, on slender footstalks. Flowers purplish, white or variegated, grouped into nearly stalkless clusters at the axils of the leaves; corolla dilated at the throat, about twice as long as the calyx; the teeth of the latter needle-pointed, bristly.

The seed (Plate 75, fig. 65) closely resembles that of cultivated hemp, though smaller, about $1 / 8$ inch long. It is broadly egg-shaped in outline, one surface rounded, the other bluntly keeled from the round, flat, depressed scar up to the iniddle. The whole seed is grayish brown, wrinkled from unevenly scattered, whitish tubercles.

Time of flowering: July to September; seed ripe in September.

Propagation: By seeds.

Occurrence: A conimon weed around barns and in rich, damp soil in grain fields in all settled parts of Canada.

Injury: This coarse-growing plant occupies much space and crowds out crops.

Remedy: Hand-pull whenever practicable. Sow clean seed and prevent plants from seeding. Close cutting for a few years will suppress it in waste places, which should be seeded to permanent grass. Thorough cultivation with short rotation of crops will eradicate it.

ALLIED SPECIES: Catnip (Nepeta Cataria L.), an introduced perennial, the seeds of which (Plate 75 , fig. 62 ) are often found in clover seed. They are about $1 / 16$ of an inch long, 
reddish brown, roundly oval, a little flattened on the inner face, which at one end has a conspicuous basal scar with two well defined, white, eye-like cavities.

American Dragon Head (Dracocephalum parviflorum Nutt.), a native annual or biennial, with seeds (Plate 75, fig. 63) much like those of Hedge Nettle, but longer (1/8-inch) and narrower, being twice as long as wide, more angular and somewhat winged and wrinkled along the angles near the apex. The basal scar is large and curved, with a slit in the middle, giving it the appearance of a mouth; whole seed dark brown, the outer convex face distinctly ridged lengthwise and granular-roughened.

Heal-all or Self-heal (Prunella vulgaris L.), native, perennial by runners. The seed (Plate 75 , fig. 64 ) is about $1 / 16$ of an inch long, brown, slightly glazed, longitudinally striped, eggshaped, sharp-pointed at the base, which bears a white, heartshaped scar with a deep depression in the centre. Commonly found in timothy and other grass seeds.

Everything that grows without being sown or planted, among a Crop that has been sown or planted, is in that Place a Weed. The whole Benefit of the Tillage was intended for the Crop, and this robs it of a Part.

-Thomas Hale, The Compleat Bady of Husbandry, 1756.

The whole land

Is full of weeds; her fairest flowers choked up,

Her fruit trees all unprun'd, her hedges ruin'd,

Her knots disorder'd, and her wholesome herbs

Swarming with caterpillars.

-Shakespeare, Richard II, Act III, Sc. iv, 1593.

The Blue Withiwinde hath slender branches and small, by which it climbeth up, and wrappeth or windeth it selfe about trees or poles. The leaves be large and corner'd, lyke to the olde leares of Irye, saving that they be not so hard. The flowers are fashioned like belles, blewe and hollowe, the seed is black, and almost three square, lying in knoppes and huskes, after the same manner as the seede of the white Binde weede. 


\section{HEDGE NETTLE (Stachys palustris L.)}

Other English names: Woundwort, Clown's Woundwort, Clown's Heal, Cockhead, Dead Nettle, Rough Weed, Hairy Mint.

Native.' Perennial by a tuber-like rootstock producing many runners. Stem erect, leafy, its edges with coarse, downward-turned hairs. Leaves stalkless, lance-shaped, oblong, tapering at the apex, rounded at the base, with rounded teeth, hairy. Flowers pale red or spotted, formed into a long, interrupted spike of 6 to 10 flowered whorls at the axils of leaves; calyx $1 / 2$ the length of the corolla, bristly hairy, with spiny teeth.

The seed (Plate 75, fig. 66) is a dark brown or black nutlet, about $1 / 12$ of an inch long, egg-shaped, pointed at the base, which bears a small, shrunken scar. The one side is sharply keeled from the scar up to $2 / 3$ the length of the seed. Surface dull, finely wrinkled. Found abundantly among screenings of western wheat.

Time of flowering: June to September; seeds ripe by July.

Propagation: By seeds and rootstocks.

Occurrence: In moist lands throughout Canada.

Injury: A secondary weed in eastern Canada and northern Alberta, giving trouble only in moist, low lands in grain fields and meadows.

Remedy: Good drainage, clean cultivation with short rotation of crops, will check this weed and enable cultivated crops to smother it out.

To put a gloss upon their practice, the physicians call an herb (which country people vulgarly know by the name of dead nettle) archangel; whether they favor more of superstition or folly, I leave to the judicious reader. There is more curiosity than courtesy to my countrymen used by others in the explanation as well as of the names, as description of this so well known herb. They grow almost everywhere, unless it be in the middle of the street; it makes the heart merry, drives away melancholy, quickens the spirit. 



\section{THE FIGWORT FAMILY (Scrophulariaceae).}

This large family does not contain many weeds. The plants are remarkably variable in appearance and habits of growth. The leaves present almost every form. The flowers are usually in spikes, as the Mulleins, or in panicles, as the rank-smelling Figworts, occasionally axillary and solitary, as the aromatic Musk Flower, but never terminal. In no family, except perhaps the Orchids, are there so many varieties of irregular corollas, which generally have 4 or 5 divisions, either slightly united at the base or completely into a tube. The fruit is a 2-celled capsule, which opens when ripe and allows the numerous seeds to drop out. The Scrophulariaceae are bitterish plants. Some contain a narcotic poison, such as the Foxglove (Digitalis). Among the weeds are the Mulleins (Thapsus); Toad Flax (Linaria vulgaris Hill.); the Speedwells (Veronica), some species of which are troublesome on lawns; Glandular Eyebright (Euphrasia arctica Lange), and Red Bartsia (Odontites rubra Gilib.), introduced, both rather common pasture weeds in Prince Edward Island; and Yellow Rattle (Rhinanthus Crista-galli L.), an annual weed in low meadows.

The Consideration of Weeds is very essential to the Husbandmen, because scarce any of his Land escapes from being abundantly infested with them; and none is ever entirely free. They utterly destroy some crops; and they never fail to injure others in Proportion to their Number and Nature.

-Thomas Hale, The Compleat Body of Husbandry, 1756.

And though theyr soyle be not verie frutefull, nor their aier very wholesome, yet againste the ayer they so defende them with temperate diete, and so order and husbande their grounde with diligente travaile, that in no countrey is greater increase, and plenty of corne and cattell, nor mens bodies of longer lyfe, and subject or apte to fewer diseases. 
TOAD FLAX (Linaria vulgaris Hill.)

Other English names: Butter and Eggs, Ramsted, Wild Snapdragon, Flaxweed, Eggs and Bacon, Yellow Toad Flax.

Other Latin names: Linaria Linaria (L.) Karst; Antirrhinum Linaria L.

Introduced from Europe. A persistent, deep-rooted perennial. Stem erect, slender, becoming wiry. Hairless, slightly waxy. Leaves, stalkless, extremely numerous, mostly alternate, linear, without teeth or divisions, acute at both ends. Flowers nearly an inch long, showy pale yellow with orange lips, borne in erect dense racemes; the 2-lobed corolla closed and mouth-like, but, by gentle pressure at the sides, it opens and closes like the muzzle of an animal.

The seed (Plate 75 , fig. 67 ) is about $1 / 12$ of an inch in diameter -including the wing-dark brown to black, flat, round or oval, disc-like, roughened, with tubercles and surrounded with a circular wing, as broad as the seed itself, finely radiate.

Time of flowering: June to September; seeds ripe by August.

Propagation: By seeds and rootstocks.

Occurrence: Quite common in eastern Canada. Spreading rapidly, especially in light and shallow soils.

Injury: A persistent weed in waste places, roadsides, meadows and erops.

Remedy: Short rotation of crops with deep, thorough cultivation in spring and fall will suppress it. Hand-pulling when the soil is wet is effective in pasture lands that ean not be eultivated. Badly infested meadows or pasture lands should be brought under cultivation by plowing in July, summerfallowing until autumn, and planting with hoed crop the following spring. 


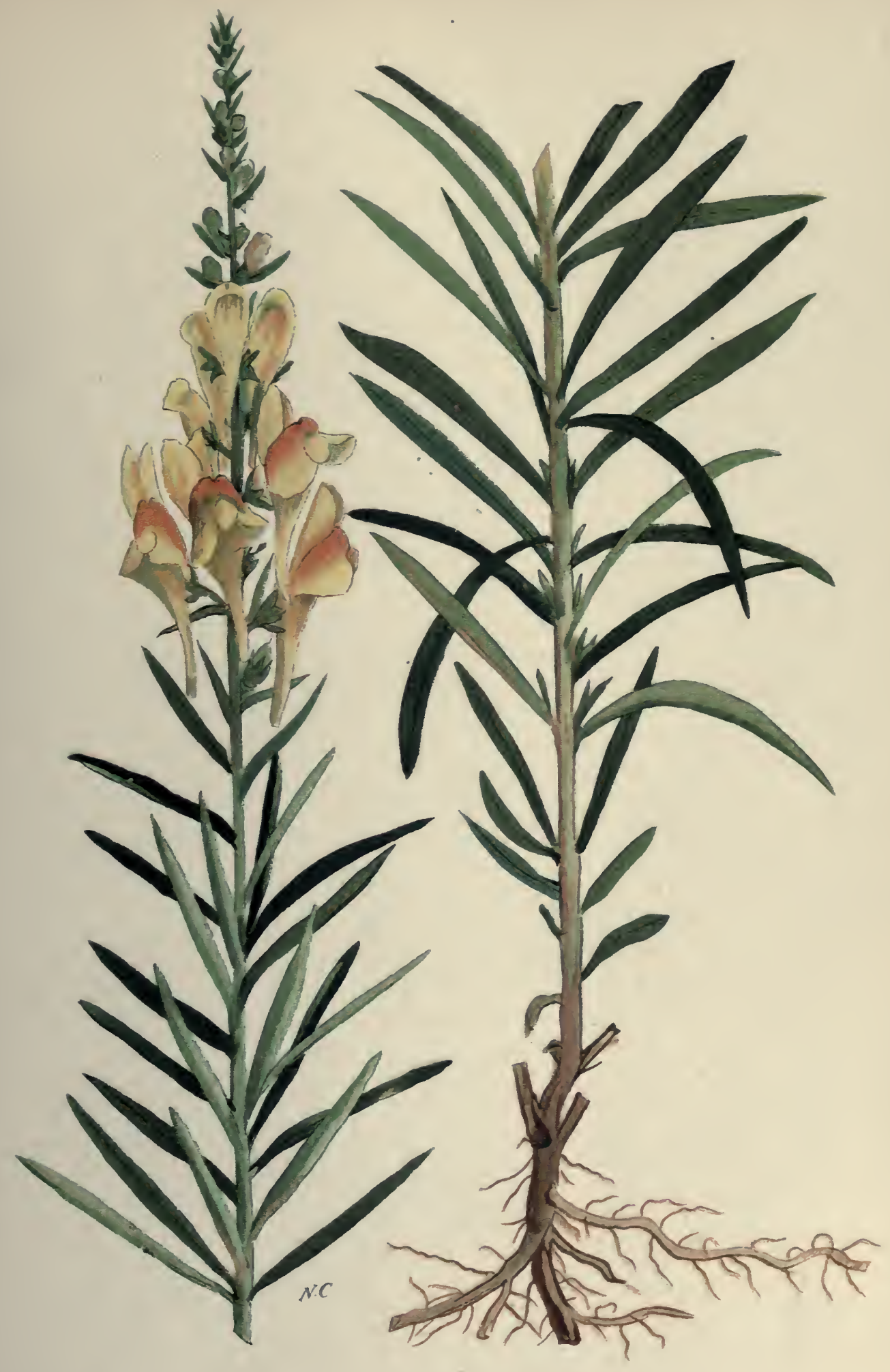

Plate 50

TOADFLAX OR BUTTER AND EGGS (Linaria vulgaris Hill) 



\section{THE RIBWORT or PLANTAIN FAMILY (Plantaginaceae).}

This family embraces a few species of stemless weeds, with inconspicuous flowers borne on long, slender spikes at the top of leafless flowerstalks or "scapes." The fruit is a capsule, the upper part of which, when the seeds are ripe, drops off like the lid of a box. The seeds are not conspicuous by their colour among grass seeds, and on account of their size and shape they are difficult to separate from them. This renders a knowledge of the appearance of the common kinds very important. The seeds of plantains may be roughly separated into two groups, according to their shape; in one division, the seeds are irregularly angular, like small grains of gunpowder, e.g., Common Plantain and Pale Plantain; in the other, they are boatshaped, hollow on one side and rounded on the other, e.g., Narrow-leaved Plantain or Rib-grass and Bracted Plantain. When moistened, all these seeds develop a coat of mucilage, by means of which their distribution is much facilitated.

The maiweed doth burne, and the thistle doth freat, the fitches pull downward, both rie and the wheat:

The brake and the cockle, be noisome too much, yet like unto boddle, no weed there is such.

- Thomas Tusser, Five Hundreth Pointes of Husbandrie, 1557.

All Plants that do draw much nourishment from the Earth, and so soak the Earth, and exhaust it, hurt all things that grow by them;.... So the Colewort is not an enemy (though that were anciently received) to the Vine onely; but it is an enemy to any other Plant, because it draweth strongly the fattest Juyce of the Earth. And if it be true, that the Vine, when it creepeth near the Colewort, will turn way: This may be, because there it findeth worse nourishment; for though the Root be where it was, yet (I doubt) the Plant will bend as it nourisheth. Where Plants are of several Natures, and draw several Juyces out of the Earth, there (as hath been said) the one set by the other helpeth: As it is set down by divers of the Ancients, that Rew doth prosper much, and becometh stronger, if it be set by a Fig-tree: Which (we conceive) is caused not by reason of Friendship, but by Extraction of a contrary Juyce; the one drawing Juyce fit to result sweet, the other bitter. So they have set down likewise, that a Rose set by Garlike is sweeter which likewise may be, because the more Fetide Juyce of the Earth goeth into the Garlick, and the more oderate into the Rose. 


\section{COMMON PLANTAIN (Plantago major L.)}

Other English names: Broad-leaf Plantain, Greater Plantain, Dooryard Plantain, Birdseed Plantain.

Introduced and native. Perennial. Rootstock short and thick, bearing many thick-spreading roots and a large tuft of dark green, oval, long-stalked, coarsely-toothed, spreading or upward curving leaves, strongly nerved underneath, and several dense spikes (3 to 12 inches long) of inconspicuous flowers with purple stamens. Seed capsules oval, dividing about the middle.

The seed (Plate 75 ; fig. 68) is about $1 / 20$ of an inch long, greenish-brown, variable in size and shape according to the number in the capsule (which varies from 8 to 16 ), rounded on the outer face, angular on the inner scar-bearing face; scar pale and conspicuous. The surface of the seed is finely netted with dark brown broken waved lines, which radiate from the scar.

Time of flowering: May, throughout the summer; seed ripe by July.

Propagation: By seeds.

Occurrence: Throughout the Dominion, generally in rich, moist soil. In various forms, some of which may be distinct species, as indicated by the difference in habit of growth and the degree of hairyness.

Injury: A persistent, succulent weed, usually abundant in fields and gardens in low, rich soils and well able to compete with most cultivated crops or natural grasses. Especially objectionable in lawns. Its seeds are common in grass and clover sceds.

Remedy: Hoed crops every four years will keep this weed in check. Working with a broad-shared cultivator, followed by a harrow, to drag the plants with their fibrous roots to the surface, is recommended for spring cultivation. Plantain in 


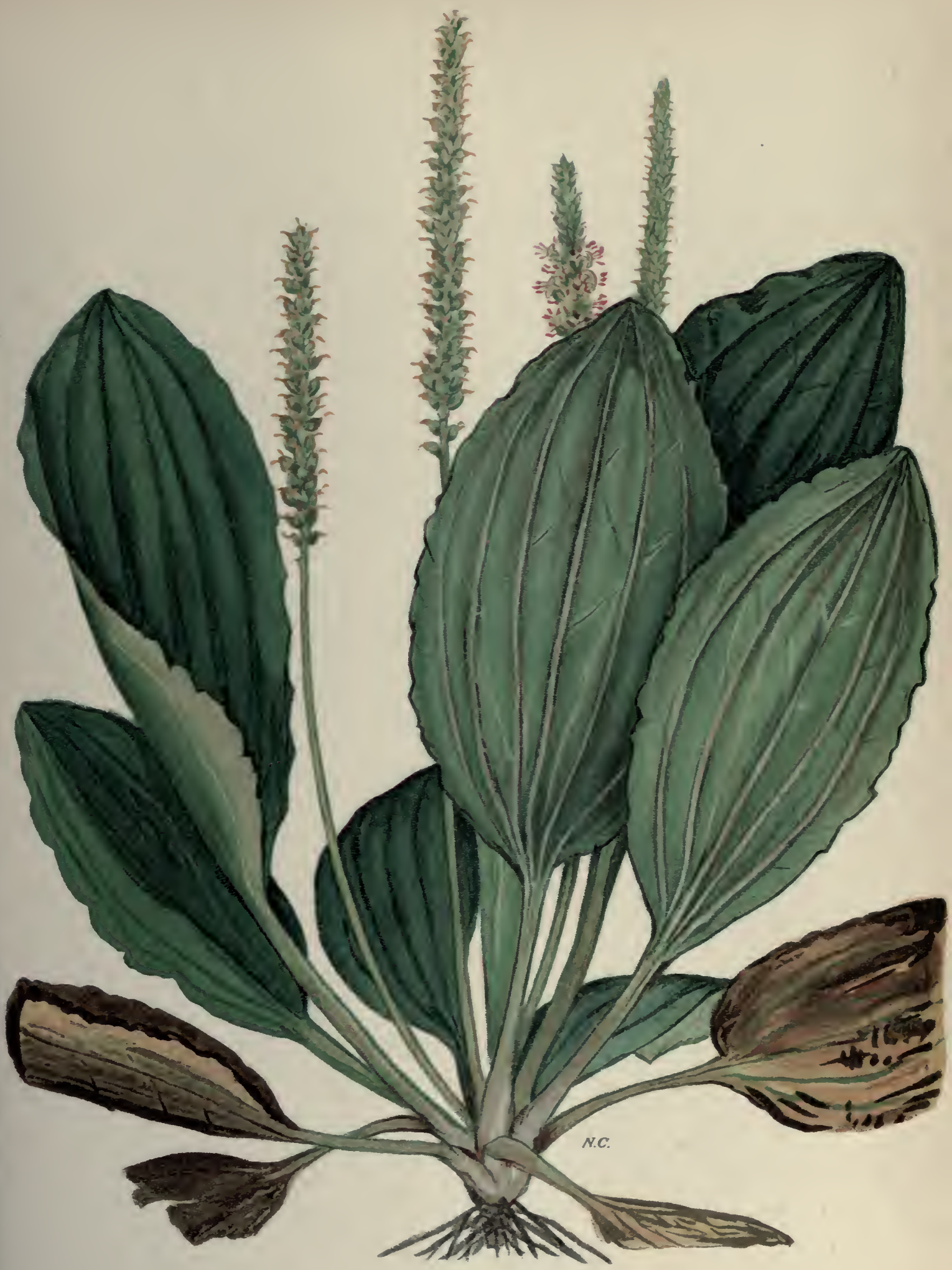

Plate 51

COMMON PLANTAIN

(Plantago major L.) 

tawns may be weeded out when the soil is firm by forcing a small implement like a chisel, with a half-round blade having a point like the tip of a spoon, between the soil and the fleshy crown of the weed to a depth sufficient to break the plant away from its fibrous roots without disfiguring the turf. A teaspoonful of salt applied to the crown of small plants in hot dry weather will kill them without seriously injuring the grass.

ALLIED SPECIES: Pale Plantain (Plantago Rugelii Dene.) often occurs with Common Plantain. It is a rather larger plant with more erect, smooth leaves, of a paler or yellowish green, the leaf-stalks purple at the base. The spikes are longer and the flowers less crowded, the capsules more pointed, 4 to 9 -seeded, opening below the middle.

The seed (Plate 75 , fig. 69) is of the same angular shape as that of the Common Plantain, but about twice as large and nearly black, with the surface merely roughened, not lined and netted. It is common in timothy and alsike seed.

\footnotetext{
Romeo.-Your plantain leaf is excellent for that. Benvolio.-For what, I pray thee? Romeo.-For your broken shin.
}

-Shakespeare, Romeo and Juliet, Act I, Sc. ii, 1591.

For the knowledge of herbes, trees, and shrubbes is not onelye very delectable for a Princes minde but profitable for all the bodies of the Princes hole realme both to preserve men from sickness, sorrowe, and payne that cometh thereby.

-William Turner, Herbal, 1568.

It is needless to go about to compute the value of the damage weeds do, since all experienced husbandmen know it to be very great, and would unanimously agree to extirpate their whole race as entirely as in England they have done the wolves, though much more innocent and less rapacious than weeds. 


\section{RIBGRASS (Plantago lanceolata L.)}

Other English names: Buckhorn, English Plantain, Ribwort.

Introduced from Europe. Perennial or biennial. Rootstock short. Leaves numerous, 2 to 12 inches long, narrowly lance-shaped and distinctly 3 to 5 -ribbed, hairy, with tufts of brownish hair at the base. In the first year the leaves lie close to the ground, forming a dense rosette; on old plants they are erect. Flower stalks stiff, slender and grooved, 1 to 2 feet, much taller than the leaves. Flower heads at first ovoid and rather showy by reason of their numerous yellow stamens, elongating with age and forming dense, cylindrical, black spikes of seed, from 1 to 4 inches long. Capsules oblong, obtuse, 2seeded, opening about the middle.

The seed (Plate 75, fig. 70) is about $1 / 10$ inch long, chestnut brown, minutely granular-roughened but highly polished, boatshaped with rounded ends, the outer face rounded with the edges folded inward around a deep, longitudinal groove, in the centre of which lies the dark-coloured scar which sometimes has a pale ring of dried mucilage around it.

Time of flowering: Throughout the summer; seed ripe by July.

Propagation: By seeds.

Occurrence: Throughout Canada; most abundant in clover crops.

Injury: In Europe, Ribgrass is considered a valuable forage plant for some soils; its seed is an article of commerce and largely used in mixtures for pasture lands. In Canada it is an injurious weed in clover and meadows for hay or seed crop. The seeds are very common in red clover seed.

Remedy: Sow clean seed. In common with other species of plantain, this weed is easily suppressed by hoed crop and short rotation. It is prevalent almost exclusively in clover 


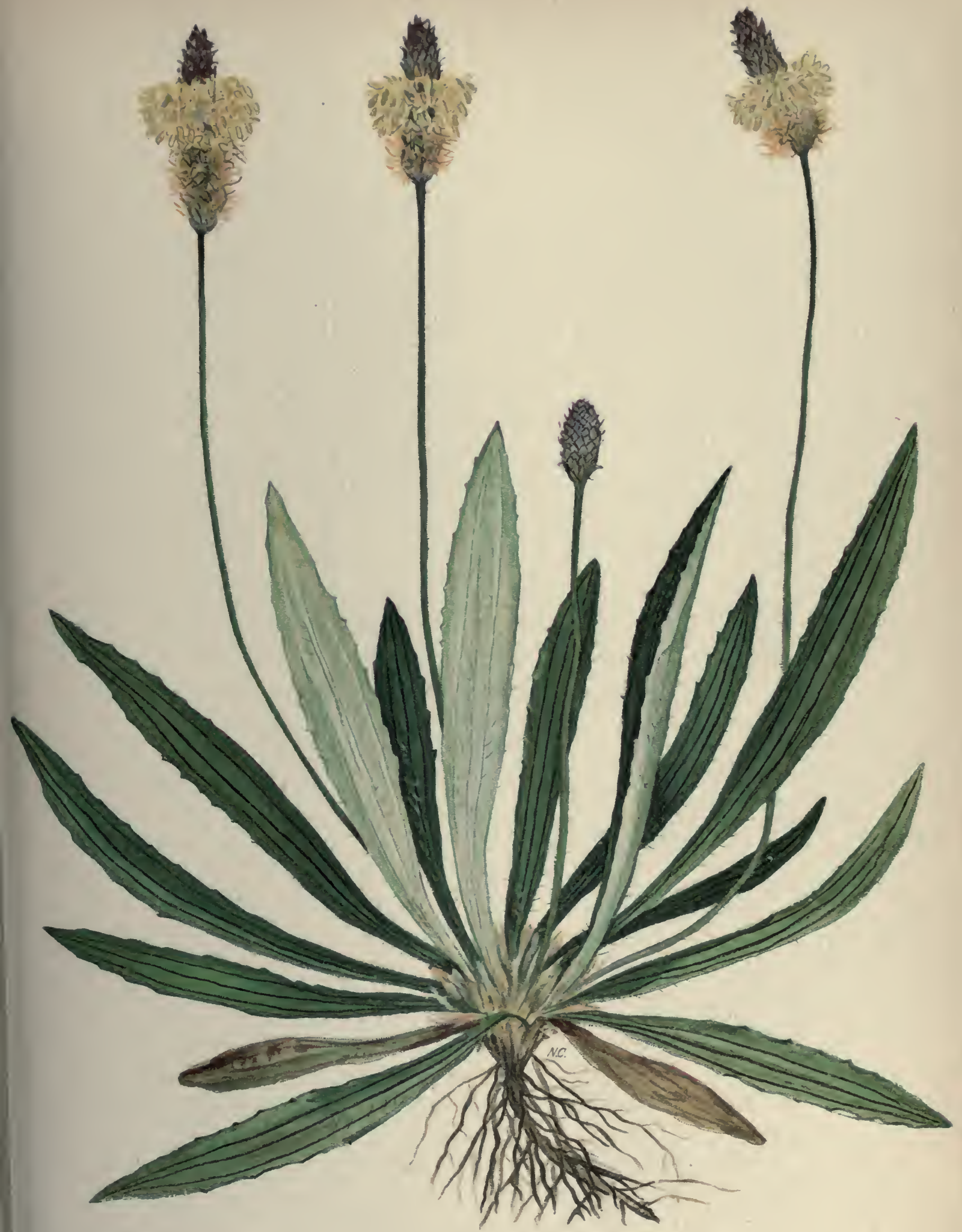

Plate 52

BUCKHORN, RIB GRASS OR ENGLISH PLANTAIN

(Plantago lanceolara.L.) 
crops, in which it increases rapidly by the distribution of its seeds with commercial clover seed, the market value of which is depreciated by this impurity. Farmers who use only first quality red clover seed and who pull the first plants of this weed that occur in their clover seed crop will soon rid their farms of this pest. Special cleaning apparatus is required to separate the seed from red clover seed. Farmers may separate small quantities by spreading the clover seed on damp canvas; the plantain seeds will quickly gum themselves to the cloth and the clover seeds will drop off when the canvas is inverted.

ALLIED SPECIES: Hoary Plantain (Plantago media L.). This plant is much less frequently seen than Ribgrass but it has the same wide range, as the seed is distributed with grass seed. It is deep-rooted and more difficult to eradicate from lawns than the other species here mentioned. Leaves ovate, thickly covered with white hairs, short-stalked and always lying close to the ground in a dense rosette. The flower stalks are slender, about 1 foot high. Flower heads showy by reason of their purple and white stamens, at first oval, gradually elongating to cylindrical spikes 1 to 3 inches long. Flowers pleasantly fragrant. Capsules oblong, 2 to 3 -seeded.

The seed (Plate 75, fig. 72) is of the boat-shaped class, about the same size as that of Ribgrass but thinner and flatter, often somewhat twisted, with the edges not so roundly turned in around the groove which bears the scar. It shows an indistinct, shallow groove or constriction across the outer face just below the middle, indicating the part of the seed which fitted into the top of the capsule.

Hoary Plantain is intermediate in appearance between Common Plantain and Ribgrass, and its seeds are intermediate between those of Ribgrass and of Bracted Plantain.

Bracted Plantain (Plantago aristata Michx.). A western annual which is rather rare in Canada, although its seeds are not uncommon in grass and clover seeds. The whole plant is downy; leaves narrow, linear, grass-like; flower stalks erect, 
bearing thick, cylindrical spikes 1 to 4 inches long, with conspicuous, pointed, bracts. Capsules 2-seeded.

The seed (Plate 75, fig. 71) is boat-shaped, of the same size and form as that of Ribgrass but slightly wider, with sharper edges to the margin of the inner face. The elongated scar consists of 2 small, shallow pits lying close together in the centre of the inner excavated face, the whole of which is whitened by a coat of dried mucilage. The rounded outer face has a distinct shallow groove crossing it just below the middle. This groove and the two pits of the scar are the best characteristics for distinguishing this seed.

\section{THE MADDER or BEDSTRAW FAMILY (Rubiaceae).}

This is a large family which shows great variations in habits of growth and in appearance. The most important members are tropical, such as the coffee. The plants are herbaceous or woody, with opposite or whorled leaves, flowers bearing both stamens and pistils and various fruits.

The seeds of the following weeds are found in commercial seeds :-

Field Madder (Sherardia arvensis L.). A slender, prostrate, square-stemmed plant, with lance-shaped leaves in whorls of 4-6, and small pink or blue flowers. The seed is ash-gray from fine appressed hairs, eggshaped, not quite $1 / 8$ of an inch long, crowned with 3 dry, persistent calyx teeth.

Northern Bedstraw (Galium boreale L.), the most common of the bedstraws or cleavers. A native perennial, with square stem, linear, lance-shaped leaves in whorls of 4 , and compact panicles of bright white flowers.

The seed (Plate 75, fig. 73) is a good representation of the seed of the genus Galium, only it is much smaller than some 
of the other species; from $1 / 20$ to $1 / 10$ of an inch in diameter, nearly round, somewhat flattened on the side bearing the scar. The whole seed, except the depression in the scar, is covered with prickly hairs, giving it a grayish colour. The scar surface is brown, rugose. The hairs are sometimes broken off by threshing and cleaning the seed.

\section{THE SUNFLOWER FAMILY (Compositae).}

This, the largest family of flowering plants, includes ten to twelve thousand species and is represented in all parts of the world by economic, medicinal and ornamental plants, and by some poisonous and weed pests. The characteristics of the family are well marked. The roots and rootstocks contain a chemical principle, inulin, which is poisonous and gives to many plants their medicinal properties. The flowers of all are composite; that is, composed of many small flowers or florets standing together on expanded enlargements, known as receptacles, at the ends of the stalks. Individually, these flower heads, or collections of many florets, have the appearance of simple flowers and are popularly so spoken of; as, for instance, the flower of a sunflower, a daisy or a dandelion, while in reality each one is a large number of flowers grouped together at the. end of a common footstalk, and what appears to be a calyx is a cluster of small bracts. A striking characteristic of this family is that the stamens are united at their edges into a vertical tube with the pistil inside. The calyx of the florets, when present, is modified in fruit into a ring of silky bristles, awns, teeth or scales, which is called the pappus. The florets of composite flowers are of two kinds, both of which may sometimes be seen in the same flower head, as in Common Sunflower. The marginal or ray flowers are strap-shaped, and the smaller centre or disc flowers are tubular. When the flower head has ray flowers, either throughout or round the edge, it is termed radiate; 
when there are no ray flowers it is said to be diseoid. T'he true seed is enclosed in a hard, dry shell, like a small nut, botanieally called an achene. There are often two forms of seeds on the same flower; the centre ones are generally straighter, narrower and more or less angled through compression.

The members of this large family are divided into two series, according to the nature of the corolla. In the first series, the Tube-flowered Composites (Tubuliflorae), the corolla is tubular and regularly 5-lobed in all the flowers which bear stamens and pistils, and strap-shaped only in the marginal or ray flowers. In the second series, the Strap-flowered Composites (Liguliflorae), the corolla is strap-shaped in all the flowers of the head. To this series, also known as the Chicory family (Cichoriaceae), the Chicory and many other plants with similar flowers belong, including numerous well known weeds, such as the dandelions, sow thistles, lettuees and hawkweeds. The great majority of the weeds in this family belong to the first series, the Tubeflowered Composites. Such a large number of plants are grouped under this series that it becomes necessary to subdivide them into tribes.

\section{TRIBE VERNONIEAE}

Ironweeds (Vernonia species) are eommon perennial weeds along roadsides and low, permanent grass lands in the southern part of the eastern provinces. They are tall plants with long leaves and red-purple flowers heads. 'They may be kept in check by continued elose eutting or easily destroyed by cultivation on lands that can be brought under the plow.

\section{TRIBE EUPATORIFAE}

Joe-Pye Weed (Eupatorium purpureum L.) grows from 4 to 8 feet high, without branches, 3 to 6 large smooth leaves, growing in whorls at the joints, and with large clusters of pale pink to whitish flowers. Common in low meadows and pastures throughout Canada. It is easily destroyed by shallow eultivation. 
Boneset (Eupatorium perfoliatum L.) is low in habit of growth; stem hairy, leaves lance-shaped and united at the base around the stem; flowers white. Common in moist, permanent grass lands in eastern Canada. Said to be of medicinal value.

White Snakeroot (Eupatorium urticaefolium Riechard) is quite common in damp, woodland pastures in Ontario and eastward. Characterized by its large clusters of showy white flower heads and long-stalked opposite leaves. This plant is distinctly poisonous and is believed to be injurious to stock.

\section{TRIBE ASTEREAE}

Gumweed or Gum Plant (Grindelia squarrosa (Pursh) Dunal.) is a coarse biennial with golden-yellow flowers, the buds of which, just before opening, have a large drop of liquid resin on them. While it is seldom troublesome in crops, it frequently grows along trails and is supposed to cause hay fever.

The seed (Plate 75, fig. 74) has been found among wheat screenings and in clover seeds and is sometimes mistaken for the seed of Canada Thistle. It.is, however, plumper, much more flattened and more angular, roughly grooved lengthwise, paler and duller in colour.

The Sunflower is the golden flower of Peru, or the Flower of the Sunne. This goodly and stately plant, wherewith everyone is now adayes familiar, being of many sorts both higher and lower, riseth up at first like unto a Pompion with two leaves, and after two it riseth up into a great stalke, bearing the leaves on it severall distances on all sides thereof, one above another unto the very toppe, being sometimes, and in some places, seven, eight, or ten foote high..... At the top of the stalke standeth one great, large and broad, flower, bowing down the head unto the sunne, and breaking forth from a great head, made of scaly greene leaves, like unto a great single Marigold, having a border of manie long yellow leaves, set about a great round yellow thrumme as it were in the middle, which are very like unto short heads of flowers, under every one there is a seede, larger than any seede of the Thistles, yet somewhat like, and lesser, and rounder than any Gourde seede, set in so close and curious a manner, that when the seede is taken out, the head with the hollow places or cels thereof, seemeth very like unto a honey combe. 
NARROW-LEAVED GOLDENROD (Solidago graminifolia (L.) Salisb.).

Other English names: Bushy or Fragrant Goldenrod, Yellow Weed.

Other Latin names: Euthamia graminifolia (L.) Nutt., Chrysocoma graminifolia L., Solidago lanceolata L.

Native. Perennial by running rootstocks. Stems erect, branching above into cymes, 2 to 3 feet high, almost smooth. Leaves numerous, linear-lance-shaped, 1 to 5 inches long, the edges rough-hairy. Separate heads of flowers about $1 / 4$ inch across, bright golden-yellow, in dense, flat-topped clusters.

The seed (Plate 75 , fig. 75) is small, white, about $1 / 12$ of an inch long, ovate-oblong, nearly cylindrical, slightly tapering, many ribbed, downy. The pappus is white, consisting of a single row of rough bristles, about twice the length of the seed.

Time of flowering: July to September; seeds ripe in September.

Propagation: By seeds blown by the wind and by long running rootstocks forming new plants at the tips, which, if left undisturbed, soon form large patches.

Occurrence: In low land throughout the Dominion.

Injury: This and many other species of the goldenrods are objectionable in meadows on damp soils, as marsh lands and river bottoms, that are not well suited for general cultivation and rotation of crops. These weeds are unpalatable to stock and their presence in hay entails much waste.

Remedy: To prevent them from spreading, occasional weeds in the meadow may be destroyed by the application of a handful of salt after cutting. Badly infested land that is wet until late in the spring should be shallow-plowed and thoroughly cultivated as soon as the hay crop is removed. These perennial pests can 
be suppressed by repeated cultivation between the middle of July and the middle of September, when the land may be seeded to winter rye with a liberal application of thoroughly clean grass seed.

ALLIED SPECIES: Several other goldenrods are rather troublesome free-growing perennials; among them are:

Tall Hairy Goldenrod (Solidago rugosa Mill.), with long hairs, crowded leaves and a broad, pyramidal panicle.

Tall or Canada Goldenrod (Solidago canadensis L.) and varieties, with a slender stem, hairless at the base, and thin, narrow-lance-shaped leaves.

Smooth Goldenrod (Solidago serotina Ait.), with stout, smooth stems, leaves smooth on both sides.

All these showy, autumn-flowering plants are wayside and grass-land weeds and do not give trouble on fields under regular cultivation.

The true Asters, of which about 70 species are native to our country, very seldom become aggressive weeds.

As for the Sow-Thistle, the chief and onely Annoyance of all Thistles (as for other Thistles I scarce know how to rank them among those grand Corrupters, because the opinion of most men are, that they are most certain symptons of, good land as usually they are; so are Nettles, Hemlocks, Mallowes, etc.), and yet I had rather they were all destroyed than remain upon my lands (but because they are of lesse offence, and we have greater Prejuideces than these, Ile let them passe); but for the Sow-Thistle it is of so great offence that it destroys all the grasse it covers, which is many times a foot round, and also so easie to be destroyed that I shall put the Grazier or farmer upon no other charge or trouble, but onely to take a little Paddle staffe, as a Walking-staffe, and give each one a chop at the Root as he passeth by them, which will be rather a Recreation to an active man, than a Burthen, and thus every day a few as they grow in bignesse, will in a few days destroy them all; Or else a Shepheard, or Keeper of the Ground, as he walks among his Cattell may easily keep them under, as he goes about his daily businesse; But since I have found out a more certain way which will destroy them at one spudding up, which being done as soon as the Thistle begins to spread, but they must be done as it were up, by, or under the root, which lyeth very overly, and if it be not cut at first chop, it may at next by the Root; I had the last yeare a field of an hundred Acres so thick over-runne, that some acres were as thick that one man could not do above halfe an Acre in a day I caused them to be spudded up by the root, which was done at two chops by my Spade, I was not onely freed of them the last Summer wholly, but my whole ground is Cleansed of them for this yeare, and so I hope for ever. I beleeve the charge thereof was neare twenty shillings, or there about. A more certaine way I know not.

-Walter Blith, The English Improver Improved, or The System of Husbandry Surveyed,1652. 


\section{COMMON FLEABANE (Erigeron canadensis L.)}

Other English names: Horseweed, Fireweed, Butterweed, Prideweed, Blood-staunch, Coris, Colt's- or Mare's-tail, Bitterweed.

Other Latin name: Leptilon Canadense (L.) Britton.

Native. Annual. Sometimes very tall and much branched, with wand-like stems; generally bristly hairy. Leaves without teeth or divisions, linear, the basal ones dentate. The numerous, small, white flower heads form a panicle.

The seed closely resembles those of the goldenrods and is practically indistinguishable from them and from some varieties of asters. It is yellowish, flattened, 2-nerved, often slightly curved.

Time of flowering: July to October; seeds ripe August to October.

Propagation: By seeds carried with the wind. Seed-producing plants are of all sizes, up to 6 or 7 feet high. An average plant produces about 120,000 seeds.

Occurrence: General in fields and waste places. A native of North America, except the extreme north. Spread from America to Europe and common in South America. It is most abundant in moist grounds and pastures, but is found in meadow land and even cultivated fields.

Injury: Its seeds are found in poorly cleaned grass seed. An objectionable weed in meadows.

Remedy: Any method of cultivation which prevents it going to seed is effective. A short rotation with clover and a hoe crop or a bare fallow will casily kill it. Waste places should be watched and the weeds cut before they develop seed.

ALLIED SPECIES: Daisy Fleabane (Erigeron annuus (L.) Pers.) has coarsely-toothed leaves. 
Rough Daisy Fleabane (Erigeron ramosus (Walt.) B.S.P.) has leaves, without teeth or divisions.

Both are common clover field weeds in all parts of eastern Canada. The seeds are sniall and are carried in grass seeds.

\section{TRIBE INULEAE}

This tribe of the Sunflower family contains a few of the plants commonly known as Everlastings, which are weeds of secondary inportance. Such are the True Everlastings, or Cat's-foot (genera Antennaria and Anaphalis) and the Cutweeds (genus Gnaphalium). Most of them are perennial, low plants of a characteristic woolly appearance, with numerous dry, chaffy, mostly white or inconspicuous flower heads. The seeds are generally very small.

Elecampane (Inula Helenium L.), also called Horsehead, is a stout perennial with a thick, mucilaginous root; introduced from Europe. The leaves are large, rough above, woolly beneath, the upper ones stalkless, clasping the stem.

The flower heads are yellowish, with many rays. The seed is about $1 / 5$ of an inch long, olive brown, 4-angled, with a long, spreading pappus.

Elecampane, the beauteous Helen's flower, Mingles among the rest her silver store.

-Rapin, 1650.

Some think it took the name from the teares of Helen, from whence it sprang, which is a fable; others that she had her hands full of this herbe when Paris carried her away; others say that it was so called because Helen first found it available against the bitings and stingings of venomous beasts; and others thinke that it tooke the name from the Island Helena, where the best was found to grow. 


\section{TRIBE HELIANTHEAE}

\section{POVERTY WEED (Iva axillaris Pursh.)}

Other English name: Small-flowered Marsh-elder.

Native. Perennial. Whole plant with a rank odour. Stems herbaceous, branching, nearly erect, from tough, woody, extensive ruotstocks, 6 to 12 inches high, very leafy. Leaves thick, obovate to linear-oblong, without teeth or divisions, rough-hairy; the lower ones opposite, the upper alternate. Flower heads drooping, solitary, on short footstalks, from the axils of the upper leaves, $1 / 6$ of an inch across, inconspicuous.

The seed (Plate 75 , fig. 77) is $1 / 8$ of an inch long; colour variable, olive-green, yellowish-brown to almost black; surface mealy and dull; pear-shaped, slightly flattened, sometimes keeled on the side and a little curved toward the base. There are seldom more than one or two seeds in each flower head, and many heads have none.

Time of flowering: June to August; seeds ripe July to September.

Propagation: Mainly by the extensive underground stems, which send up many flowering, leafy shoots.

Occurrence: In grain fields and pastures from Manitoba to the interior of British Columbia, thriving in all soils but occurring generally on land where there is some alkali. The seed of Poverty Weed seldom occurs in grain or grass seeds.

Injury: A persistent perennial, forming large patches. Exhaustive of moisture, thus starving crops and rendering the land hard to work.

Remedy: This is a difficult enemy to dislodge when well established on the rich soils of the West. It requires well directed, persistent effort, with sharp implements. Plowing for summerfallow should be clean and deep, followed by frequent cultivation with a broad-shared cultivator. 


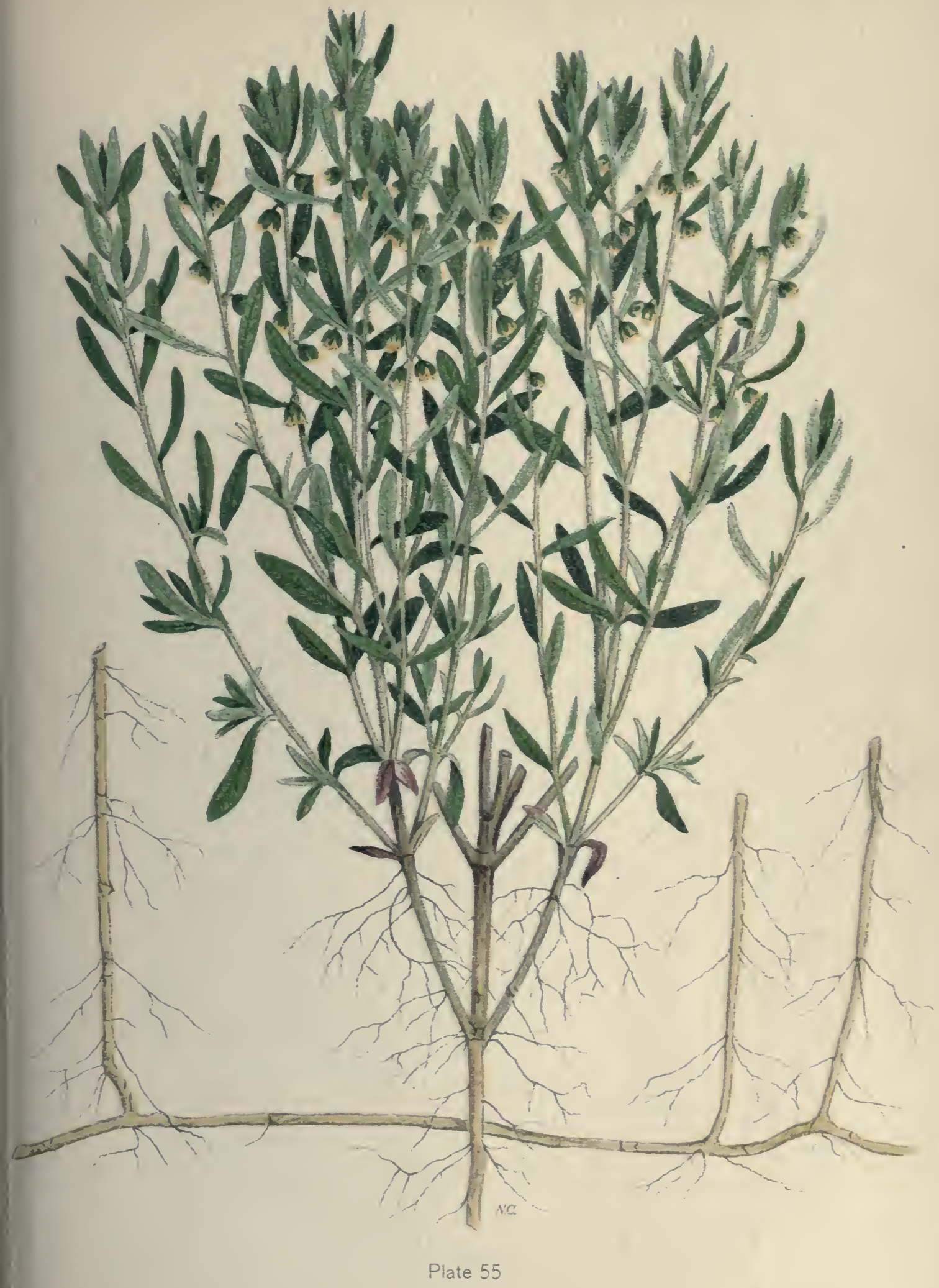


ALLIED SPECIES: False Ragweed (Iva xanthifolia Nutt.), a coarse annual which grows to a height of 6 to 8 feet and produces an enormous quantity of seed. Before flowering it has a remarkable superficial resemblance to Great Ragweed, having the same habit of growth and leaf outline; but it can be recognized at once by the stem, which is perfectly smooth, while in Great Ragweed both the stems and the leaves are noticeably rough; when full grown, the resemblance between the two plants disappears. False Ragweed bears a large, loose panicle of darkcoloured flowers at the top of the stem, while Great Ragweed has a long, rat-tail-like spike of male flowers at the tip of each branch.

The seed (Plate 75, fig. 76) is of the same general shape as that of Poverty Weed, but is only $1 / 10$ of an inch long, more tapering and finer, somewhat darker in colour, the surface finely striated lengthwise. When fresh it has a gray, mealy covering, which partially rubs off and gives it a mottled appearance. It is ocassionally found among grain, grass and alfalfa seed of western production.

False Ragweed is quite common in parts of the West, occuring principally in rich land around farm buildings and waste places. It does not often give trouble in cultivated fields, and can be kept in check by repeated cutting to prevent seeding.

The seeds of some weeds, particularly the different species of the thistle, are carried to a considerable distance by the wind; and where any earth is grown up in such a manner as to intangle them, as at the root of a hedge, or side of a ditch, there they appear in great plenty. It is surprising, that many farmers allow them to grow there undisturbed: the consequence of which is, that their seeds are carried in great plenty into the adjacent fields, and thereby great damage is done; which might have been prevented by cutting them down, at a small expense, before their seeds were ripened. 


\section{GREAT RAGWEED (Ambrosia trifida L.)}

Other English names: Tall Ragweed, Crownweed, Kingweed, Bitterweed.

Native. Annual. A tall, coarse-branching plant, 4 to 8 feet high, with rough stems and leaves. Leaves pale green, opposite, on long, margined footstalks, variable in shape, on young plants deeply indented but scarcely lobed; as the stems grow, 3 or even 5-lobed leaves are produced, but on many plants leaves may be found without lobes. The male and female flowers are borne in different heads on the same plant; the male in long, slender spikes at the ends of the branches, and the female 2 or 3 together, stalkless, in the axils of the leaves at the base of the spikes. Male flowers $1 / 4$ inch across, cup-shaped, nodding; stamens yellow and conspicuous. Female flowers inconspicuous; pistils slender and purplish.

The seed (Plate 75 , fig. 78 ) is about $1 / 4$ inch long, brown, urn-shaped, tipped with a tapering beak and bearing around the base of this, about $1 / 3$ from the top, 6 or 8 blunt spines, like the points of a crown, which are the ends of more or less distinct ribs. This crown-like appearance of the top of the seed has suggested the names Kingweed and Crownweed, sometimes used by millers.

Time of flowering: July, seed ripe by the beginning of August.

Propagation: By seeds, which are distributed in grain and carried by water. Wheat from some districts of the West often contains considerable quantities of Great Ragweed seed.

Occurrence: Ontario and occasional in other eastern provinces. Abundant in the rich Red River Valley in Manitoba and extending westward mostly along the railways. 
Injury: This coarse annual crowds and starves grain growing near it, but the chief loss to farmers is due to the difficulty millers experience in separating the seed from grain, owing to its similarity to wheat in size and weight. The spines catch in the meshes of the screens and give trouble in cleaning.

Remedy: This is one of the few weeds in Manitoba for which hand-pulling is practicable. As a rule, the plants are conspicuous and grow near the edges of the fields. The labour required in pulling this weed before the seed is ripe is more than repaid by the increased value of the grain harvested. Special attention should be given to fields along streams that are liable to be flooded. A mowing machine should be used around the edges of infested fields before the seed is ripe.

This is true, that where Kine feed upon Wilde Garlick, their Milk tasteth plainly of the Garlick. And the Flesh of Muttons is better tasted where the Sheep feed upon Wilde Thime, and other wholesome Herbs.

-Bacon, Natural History, 1625.

Most subject is the fattest soil to weeds.

-Shakespeare, 2 Henry VI, Act IV, Sc. iv, 1592.

There are many ancient and received Traditions and Observations, touching the Sympathy and Antipathy of Plants; for that some will thrive best growing near others, which they impute to Sympathy; and some worse, which they impute to Antipathy. But these are idle and ignorant conceits, and forsake the true indication of the causes; as the most part of Experiments, that concern Sympathies and Antipathies do. For as to Plants, neither is there any such secret Friendship, or Hatred, as they imagine. And if we should be content to call it Sympathy and Antipathy, it is utterly mistaken; for their Sympathy is an Antipathy, and their Antipathy is a Sympathy: For it is thus, wheresoever one Plant draweth such a particular Juyce out of the Earth, as it qualifieth the Earth, so as that Juyce which remaineth is fit for the other Plant, there the Neighborhood doth good, because the nourishments are contrary, or several: But where two Plants draw (much) the same Juyce, there the Neighborhood hurteth; for the one deceiveth the other. 
COMMON RAGWEED (Ambrosia artemisiifolia L.) Hogweed.

Other English names: Roman Wormwood, Smaller Ragweed,

Native. Annual. A coarse, branching plant with hairy stems, 2 to 4 feet high. Leaves thin, smooth above, grayish white beneath from short, downy hairs, much cut up, pinnatifid, twice divided. Flowers closely resemble those of Great Ragweed but are smaller. Occasional plants bear only female flowers.

The seed (Plate 75 , fig. 79) is from $1 / 12$ to $1 / 6$ of an inch long, dull, light straw to dark brown, somewhat pear-shaped, the apex long and tapering to a sharp point. The surface is veined and slightly ridged lengthwise. This ridge usually terminates in sharp teeth, which form a circle around and point toward the apex. These teeth vary in number, size and regularity and are sometimes entirely absent. The outer covering of the seed is brittle and may be more or less broken away, thus revealing a smooth, brown, inner cover. The breaking off of this second coat shows the inside seed, which is greenish-white, nearly round and slightly pointed at the base. Ragweed seed appears in red clover under these different forms, sometimes in large quantities, and can be separated only with much difficulty.

Time of flowering: July; seed ripe in August.

Propagation: By seeds, carried in the seeds of grain, clovers and grasses.

Occurrence: In rich land and waste places throughout eastern Canada and in the Prairie Provinces. Exceedingly prevalent in southwestern Ontario.

Injury: This weed has a detestable odour and flavour and is disliked by cattle in pasture or hay; its presence results in considerable waste of fodder or forage. Where it is abundant it will taint milk. It is a vigorous plant, occupies much space, and thus reduces the crop yield.

Remedy: Sow clean red clover seed. Stubble lands where this weed is prevalent should be shallow-plowed directly after 
harvest, or, if seeded, the autumn growth should be closely cut with a mowing machine within two weeks after the grain crop is cut. Hoed crops require attention with the hoe occasionally after general cultivation is discontinued. Lands badly infested should be put under a three-year rotation of crops, with prompt and thorough cultivation or mowing in early autumn after the crop has been removed.

ALLIED SPECIES: Perennial Ragweed (Ambrosia psilostachya DC.) is a western plant found on the prairies, resembling Common Ragweed in the shape of the leaves and flowers but with running perennial rootstocks, which throw up at intervals weak stems, 1 to 2 feet high. Leaves finely downy. The seed closely resembles that of the above, but as a rule is more, regularly oval.

This ragweed is seldom troublesome in Canada, either on farms or from the presence of the seeds among crop seeds. With the more extensive cultivation of grasses and alfalfa for seed in the West, it will require more attention.

Cockleburs or Clotburs (Xanthium) are tall, coarse, much-branched annuals. The leaves are heart-shaped or ovate, except in Spring Clotbur (Xanthium spinosum L.), which has lance-shaped or ovate-lance-shaped leaves, tapering at both ends. As in the ragweeds, spikes of male flowers are borne above with numerous clusters of female flowers below them.

The 2-celled "fruits," commonly called "burs," are from 1 to $1 \frac{1}{2}$ inches long, hard and leathery, armed with beaks (except in Spring Clotbur) and covered with more or less long, thick, hairy, recurved and crowded prickles. Each bur contains 2 oblong, flat seeds which retain their vitality for several years.

Some species are abundant as weeds in river bottoms and moist soils throughout the Prairie Provinces, and are particularly troublesome to stockmen in parts of Alberta. Other species are plentiful in the eastern provinces and are frequently reported as a nuisance in sheep pastures.

These coarse, annual weeds should be destroyed by handpulling, continued from year to year. 


\section{CONE FLOWER (Rudbeckia hirta L.)}

Other English names: Black-eyed Susan, Yellow Daisy, Orange Daisy, Nigger Head, Golden Jerusalem; sometimes miscalled Ox-eye Daisy.

Native. Biennial. Coarse, rough, hairy throughout. Stem simple, sometimes branched below. Leaves thick, without teeth or divisions, the upper ones oblong-lance-shaped, stalkless, the lower ones broader at the top, tapering towards the base, on footstalks. The mode of flowering is by showy, terminal, usually solitary heads, glaring golden-orange, about the size of those of Ox-eye Daisy. Rays 10 to 20, much longer than the hairy scaly bracts around the flower head. The dark brown centre, with its chaffy scales hairy at the top, is high, cone-shaped, and of ten becomes column-shaped in fruit.

The seed (Plate 75 , fig. 80 ) is about $1 / 12$ of an inch long, black, 4-angled, narrow, with parallel sides; each side with fine, parallel longitudinal lines. The top of the seed is flat and bears no pappus.

Time of flowering: June to August; seed ripe by August.

Propagation: By seeds.

Occurrence: In prairie and pasture lands, old meadows and occasionally in cultivated fields. Abundant in Quebec, where it has doubtless been introduced from western Canada.

Injury: Objectionable in pastures to all kinds of live stock except sheep, which eat it when their pasture is short. When prevalent in meadows it materially reduces the yield and quality of hay. The seeds are frequently present in grass seed.

Remedy: Continued cutting for a few years, to prevent the plant from seeding, will suppress it. The seeds are relatively short-lived. Old meadows should be cut early or brought under cultivation for a few years. Sheep in sufficient numbers will suppress this weed in pasture lands.

ALLIED SPECIES: Some Wild Sunflowers are noticeable weeds in the Prairie Provinces. In Manitoba Black- 


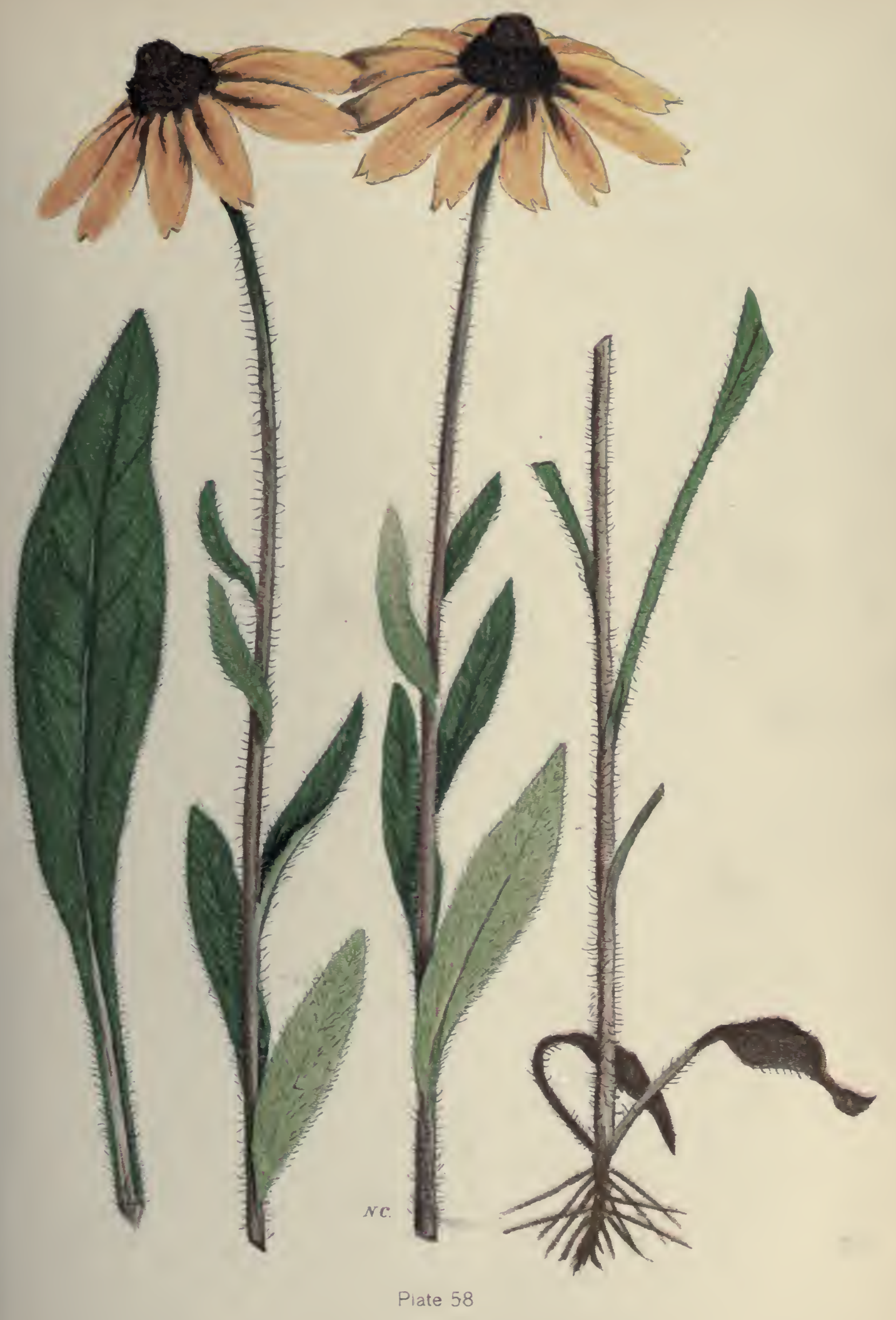

YEILOW DAISY OR BLACK-EYED SUSAN (Rudbeckıa hirra /.) 

headed Sunflower (Helianthus scaberrinus Ell.) and Manyflowered Prairie Sunflower (Helianthus Maximiliani Schrad.) are the most abundant, but Wild Artichoke (Helianthus doronicoides Lam.) is the most difficult to eradicate; for all these, early summer-fallowing is the best method.

The seeds are often found among western grain. The seed of Many-flowered Prairie Sunflower (Plate 75, fig. 81) is about $1 / 6$ of an inch long, brown, variable in shape but mostly narrowly oblong, egg-shaped in outline, flattened and rather angular, grooved lengthwise, cross-mottled with irregular, zigzag, white lines; both scars, at the top and the base, are conspicuous, the latter rather oblique.

The Bur Marigolds or Beggar-ticks (genus Bidens) are mostly swamp and wet meadow plants. One of them, Common Beggar-tick or Pitch-forks (Bidens frondosa L.) is a native weed of general distribution. It is a tall, branching annual, with 3 to 5 divided leaves and yellow flowers. The seed is enclosed in a flat, wedge-shaped fruit, often roughened with tubercles, olive brown, about $1 / 4$ to $1 / 3$ of an inch long, provided with 2 awns, $1 / 2$ as long as the fruit itself, downwardly barbed.

Close cutting from year to year when the plant is in early bloom will keep this weed in check by preventing the production of seed.

\section{TRIBE HELENIEAE}

The only member of this tribe that is recognized as a weed is Sneezeweed, False Sunflower or Yellow Star (Helenium autumnale L.), a native perennial found in moist soils, much resembling some species of sunflowers. The whole plant is aromatic, resinous. The leaves are firm, oblong-lance-shaped, generally toothed, wing-like, and extend down the stem. The bright yellow rays are 3 -cleft.

The seed is about $1 / 12$ of an inch long, angled, ribbed, hairy on the angles. The pappus consists of chaffy scales running into bristles. 


\section{TRIBE ANTHEMIDEAE}

\section{STINKING MAYWEED (Anthemis Cotula L.)} Fennel.

Other English names: Mayweed, Dog's Chamomile, Dog

Other Latin name: Maruta Cotula DC.

Introduced from Europe. Annual or winter annual. Dull green, slightly hairy or hairless, with an acrid taste and a strong, fetid odour. Stems 12 to 18 inches high, much branched from the root up. Leaves finely dissected, twice or thrice pinnatifid. Flower heads numerous, white, yellow-eyed, daisy-like, only about 1 inch in diameter, supported by slender, naked footstalks, forming a flat top bunch. Toward maturity the rays turn abruptly downward.

The seed (Plate 76 , fig. 83) is small, about $1 / 16$ of an inch long, ovate-oblong or oblong, cut off straight at the upper end, with a small knob in the centre, the smaller end abruptly pointed. The surface roughened with tubercles arranged more or less symmetrically in about 10 longitudinal rows; sometimes, however, the surface is nearly smooth.

Time of flowering: Summer to autumn; seed ripe by July and young plants sometimes abundant in September.

Propagation: By seeds.

Occurrence: A common weed in old settlements, around buildings, along roads and in waste places, from the Atlantic Coast to Manitoba, where it is rare as yet and found only along railways but is rapidly appearing in new districts.

Injury: An objectionable pest in fields and gardens; most abundant where crops have killed out in wet places. The seed is a common impurity in grass and clover seeds. The dust from Mayweed, ragweeds and others of this family, produced in threshing grain, is irritating, if not poisonous. 
Remedy: Sow clean grass and clover seeds. Do not allow the plant to mature. Clean up waste places about farmyards and seed to permanent grass that will take full possession of the soil to the exclusion of this and other weeds. The plant is usually prevalent in gardens fertilized with manure from city stables. The seeds are not long-lived and the vitality of many would be destroyed by piling the manure and allowing it to ferment for a few months.

ALLIED SPECIES: In the Maritime Provinces Scentless Mayweed or Chamomile (Matricaria inodora L.) is commonly found growing with the above. The two plants resemble each other, but Scentless Mayweed is a much handsomer plant, with flower's nearly 2 inches across and foliage of a dark, rich green. It lacks the unpleasant odour.

The seed is entirely different, being about $1 / 10$ of an inch long, square, somewhat flattened, dark brown except the margined top and the 4 very prominent, wing-like ribs, present in some seeds, which are generally much paler.

Yarrow or Milfoil (Achillea Millefolium L.) is a well known plant by waysides and in meadows throughout the Dominion. A native form in the West occurs high up on the mountains as well as on the prairies. The erect stems, 6 to 18 inches high, bear flat-topped clusters of white flower heads and finely-divided, fern-like leaves.

The seed (Plate 76 , fig. 82 ) is about $1 / 16$ of an inch long, gray with a white margin, flat and thin, oblong-wedge-shaped. It is similar to the seed of Ox-eye Daisy, but flat, smooth and ribless. Often found among seeds of the smaller grass.

Who soweth his Barley too soon, or in Rain, Of Oats and of Thistles shall after complain. I speak not of May weed, of Cockle and such, That noieth the Barley so often and much. 
OX-EYE DAISY (Chrysanthemum Leucanthemum L.var.pinnatifidum Lecoq \& Lamotte)

Other English names: White Daisy, White Weed.

Other Latin name: Leucanthemum vulgare Lam.

Introduced from Europe. Perennial, shallow-rooted. Stems numerous, simple or little branched, 1 to 3 feet high. Basal leaves are more or less pinnatifid or coarsely and irregularly toothed; middle and upper stem-leaves narrowly oblong or somewhat lance-shaped, conspicuously pinnatifid at the base. Flower heads solitary on long, naked footstalks, very handsome, $1 \frac{1}{2}$ to 2 inches across; rays 20 to 30 , pure white, spreading, 2 to 3 -toothed at the apex; centre flowers yellow.

The seed (Plate 76 , fig. 84) is $1 / 12$ of an inch long, clubshaped or elongate-ovate, usually curved, almost straight on one side and convex on the other, the knob-like scar at the top prominent; 10 well-defined white ridges run the whole length of the seed, meeting at both ends; between these ridges the surface of the seed is black, minutely dotted with white; no pappus. A single plant produces from 5,000 to 8,000 seeds.

Time of flowering: June; seeds ripe in July.

Propagation: By short offsets from the woody rootstock, and more abundantly by seeds.

Occurrence: Enormously abundant in old pastures, in meadows and by roadsides from the Atlantic Coast to the borders of Manitoba and occasional along the railways to the Pacific Coast.

Injury: A vigorous, persistent weed in old meadows, where it soon chokes out the grass. It frequently gives trouble in lawns. The seed is common in timothy and other grass seeds.

Remedy: Sow clean seed. Shallow plowing of sod in August, with thorough cultivation from time to time until frost, will 


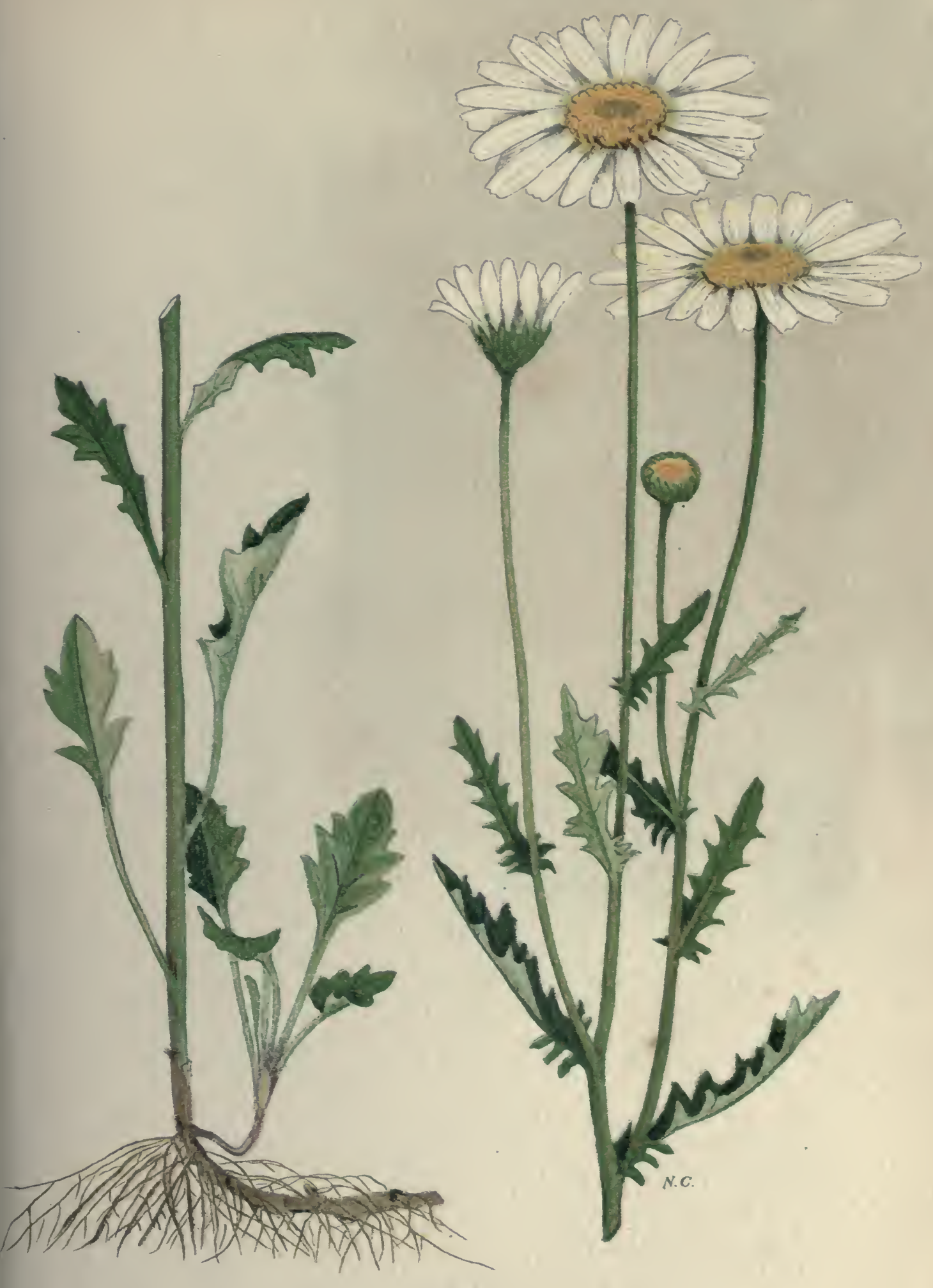

Plate 60

OX-EYE OR WHITE DAISY

(Chrysanthemum Leucanthemum livi:pinnatifinum Lersy \&lamare.) 

suppress it. This pest does not give trouble on lands worked under a sliort rotation of crops. Clover for hay in which this weed is plentiful should be cut early. Pasture lands overrun with it may be devoted to sheep grazing. Timothy containing Ox-eye Daisy should not be taken for seed.

ALLIED SPECIES: To the tribe Anthemideae belongs Common Tansy (Tanacetum vulgare L.) which is quite different from Common Ragwort, although the two plants seem to be confused in the Maritime Provinces. Tansy has almost rayless flowers; quite smooth, 5-ribbed seeds, with 5 blunt teeth at the top instead of a silky pappus. The plant is pleasantly aromatic instead of rankly fetid, a characteristic which in Nova Scotia has gained for Common Ragwort the name of Stinking Willie.

On the western plains there are many species of Wormwoods (Artemisia) which are spoken of collectively as Sage Brushes. Two of these, Pasture Sage (Artemisia ludoviciana Nutt.) and the so-called Sweet Sage or Lesser Pasture Sage (Artemisia frigida Willd.) sometimes infest home pastures, where the grass has been eaten close, necessitating breaking up the sod. The best known of the wormwoods is False Tansy (Artemisia biennis Willd.), a biennial which occurs in all parts of Canada. Although easily eradicated, it is an unsightly weed. It is quite common among grain crops on stubble. The seed (Plate 76 , fig. S5) is $1 / 15$ of an inch long, dark brown, egg-shaped, wrinkled lengthwise, and with a conspicuous, pale-coloured, ring-like basal scar.

They seem to have paid more attention formerly, at least in some parts of Scotland, to the extirpation of annual weeds than is thought of at present. It is recorded that an intelligent landlord, Sir William Grierson, was accustomed to hold Goul (Chrysanthemum) courts, for the express purpose of fining the farmers, on whose growing crop three heads, or upwards of that weed was found. Such a practice if annually adopted would soon extirpate annual weeds. 


\section{TRIBE SENECIONEAE}

\section{COMMON RAGWORT (Senecio Jacobaea L.)}

Other English names: Stinking Willie, Baughlan, Tansy Ragwort, Staggerwort, St. James'-wort.

Introduced from Europe. Perennial from few shallow, short, thick rootstocks. Under cultivation many plants, after flowering the second year, die without making any offsets. Whole plant almost hairless or with tufts of woolly hairs at the base of the leaves and flower heads and straggling hairs over the whole surface. Stem stiff, erect, grooved, 2 to 3 feet; much branched above. Root-leaves 6 to 8 inches long, stalked; stemleaves stalkless, embracing the stem; all leaves dark green, deeply twice pinnatifid, the segments crowded and overlapping, crisped and waved. Flower heads golden-yellow and very showy; $3 / 4$ inch across; numerous, erect, arranged in flat-topped, dense, compound corymbs.

The seeds (Plate 76 , fig. 86) are about $1 / 12$ of an inch long, creamy white, oblong, excavated at the top, with a small central point, deeply grooved along the sides; those of the centre almost straight, more or less angled, with short bristles; those of the ray-flowers smooth, much curved and broader; pappus white.

Time of flowering: July till November; seed ripe by August.

Propagation: By seeds and by a few offsets from the base of the stem.

Occurrence: Abundant in Pictou and Antigonish counties in Nova Scotia and in parts of Prince Edward Island; also reported from Quebec and the township of Puslinch in Ontario. It looks as though Ragwort had been imported into Nova Scotia from Scotland and into Prince Edward Island from Ireland, where it is known under the same name, Baughlan, as it bears in its new home. 
Injury: This weed causes a curious and fatal disease of the liver (hepatic cirrhosis) in cattle. For many years it was suspected that Ragwort was the cause of this malady, and this has recently been conclusively proved by experiments carried out by Dr. W. H. Pethick, of Antigonish, under the direction of the Dominion Veterinary Director General, Dr. J. G. Rutherford. The disease, previously supposed to be contagious, has been removed from the list dealt with under the Animal Contagious Diseases Act.

Remedy: Every effort should be made to eradicate this coarse, conspicuous and dangerous plant, now that there is proof of its nature. It does not increase extensively from the root and there is good evidence that where it is mowed systematically it soon disappears. In pastures and meadows every plant should be grubbed out before the seeds form. Ragwort is not readily eaten by cattle when green; the first attention should therefore be given to cleaning meadows, because it is eaten by all kinds of stock when mixed with hay. A short rotation of crops would at once exterminate it. Sheep can eat this weed with comparative impunity and it dies out when closely eaten off. Systematic and combined effort should be made by municipal authorities to have it destroyed along roadsides.

ALLIED SPECIES : Common Groundsel (Senecio vulgaris L.) has been introduced from Europe and is now found in gardens, rather rarely in Ontario and Quebec and the Prairie Provinces but abundantly in the Maritime Provinces and on the Pacific Coast. It is a small, branching plant, 6 to 8 inches high, bearing many tassel-like rayless flowers. The seed is long and narrow, spindle-shaped, the upper end blunt and slightly enlarged by the white apical scar; surface finely ridged lengthwise, and covered with short white bristles, differing in this from the seed of the similar Stinking Groundsel (Senecio viscosus L.) which occurs in the Maritime Provinces with Common Groundsel. Stinking Groundsel is viscid-hairy, its flower heads bear marginal ray-florets, and the seed is rather long, entirely without bristles. 
Fireweed (Erechtites hieracifolia (L.) Raf.) is a tall ranksmelling annual, with general habits of growth like some varieties of groundsel. The branched stem is succulent and characteristically striate. The flower heads are numerous, small, whitish and conspicuously swollen at the base before opening.

The seed is small, linear-oblong, tapering at the end and bearing a thick pappus of fine, soft, white hairs.

The common name, Fireweed, comes from the fact that this weed often occurs on land that has been swept by fire.

\section{TRIBE CYNAREAE}

\section{LESSER BURDOCK (Arctium minus Bernh.)}

Other English names: Bardane, Common Burdock, Clotbur.

Other Latin names: Lappa minor DC., Arctium Lappa L., var. minus Gray.

Introduced from Europe. Biennial, from a deep, thick, taproot. Root-leaves large, heart-shaped, downy beneath, somewhat resembling those of rhubarb, footstalks hollow. Flowering stem much branched, from 3 to 6 feet high. Flowers purple, flower heads numerous, $3 / 4$ inch across, in clusters at the tips of the branches and in the axils of the upper leaves, ovalglobular; the scaly bracts surrounding the flower-heads ending with hooks, by which the seed-bearing heads become burs and are distributed by adhering to passing animals.

The seed (Plate 76 , fig. 87 ) is about $1 / 4$ of an inch long, pale brown with dark, transverse, zigzag, depressed marks, oblong-. ovoid, cut off abruptly at each end, flattened, with about 5 longitudinal ridges generally somewhat curved; apical scar circular with a central point; pappus, when present, consisting of several rows of short bristles, upwardly barbed. 
Time of flowering: July-August; seed ripe by September.

Propagation: By seeds.

Occurrence: Rich land in the older settled provinces; common by roadsides, in waste places and orchards in sod.

Injury: An unsightly weed about farmyards, waste places and in orchards. It is especially objectionable in pastures where sheep are kept. It seldom gives trouble in fields under clean cultivation.

Remedy: Cut below the crown or spud out when the ground is wet and soft, either the first year or before the seeds are ripe the second. A handful of salt applied after cutting in hot dry weather will kill the plant. Waste places should be seeded to grass and the weeds kept out until the grass has become firmly established.

ALLIED SPECIES: Great Burdock (Arctium Lappa L.), not as common as Lesser Burdock, is a larger, coarser plant, with much larger, green flower heads, $1 \frac{1}{4}$ inch across, with hooked scales and more spreading and longer leaf stalks.

For out of the old fieldes, as men saithe,

Cometh al this new corne fro yere to yere,

And out of old bookes, in good faithe,

Cometh al this new science that men lere.

-Chaucer, The Assembly of Foules, 1381.

If we rightly consider the Addresses of this Divine Contemplation of Herbs and Plants, with what alluring Steps and Paces the Study of them directs Us to an admiration of the Supream Wisdome; we cannot but even from these inferiour things arrive somewhat near unto a heavenly Contentment. 


\section{CANADA THISTLE (Cirsium arvense (L.) Scop.)}

Other English names: Creeping Thistle, Soft Field Thistle.

Other Latin names: Carduus arvensis (L.) Robs.; Cnicus arvensis $\mathrm{Hoff} \mathrm{m}$.

Introduced from Europe. Perennial with deep running rootstocks. Stems erect, 2 to 4 feet high, marked with fine longitudinal lines. Leaves variable in shape, deeply pinnatifid, waved and crested, very prickly, in some plants much less so than in others, somewhat downy, particularly beneath. Flower heads numerous, in a large loose corymb at the top of the stems. Flowers variable in colour, ranging from pale purple through shades of pink to white. Some plants bear male flowers only, which form no seeds, other plants female flowers only, which produce many seeds; the flower heads of male plants are nearly globe-shaped, 1 inch across, those of the female plants only about half as large, oblong, with short florets. Large patches may be found bearing only male flowers, showing that all the plants originated from a single seed.

The seed (Plate 76, fig. 89) is $1 / 8$ of an inch long, light brown, elongated oblong, smooth, somewhat flattened and curved, more or less bluntly angled, marked with faint longitudinal lines; the top is nearly round, flat, and has a narrow rim with a small cone-shaped point in the centre; pappus copious, white. The pappus easily breaks off by threshing and handling and is absent when the seed is found in commercial grain and seeds.

Time of flowering: June to August; seed ripe by July.

Propagation: By seeds and extensive rootstocks, which send up both leafy barren shoots and flowering stems. This well known pest, which, although called Canada Thistle in North America, is really the Field or Creeping Thistle of England, has been introduced into almost all the British colonies and has everywhere proved a troublesome and persistent enemy of farmers. The rootstocks run down into the soil from eight to fifteen inches, and often much deeper; when patches are covered up stems can be thrown up through many feet of soil. 


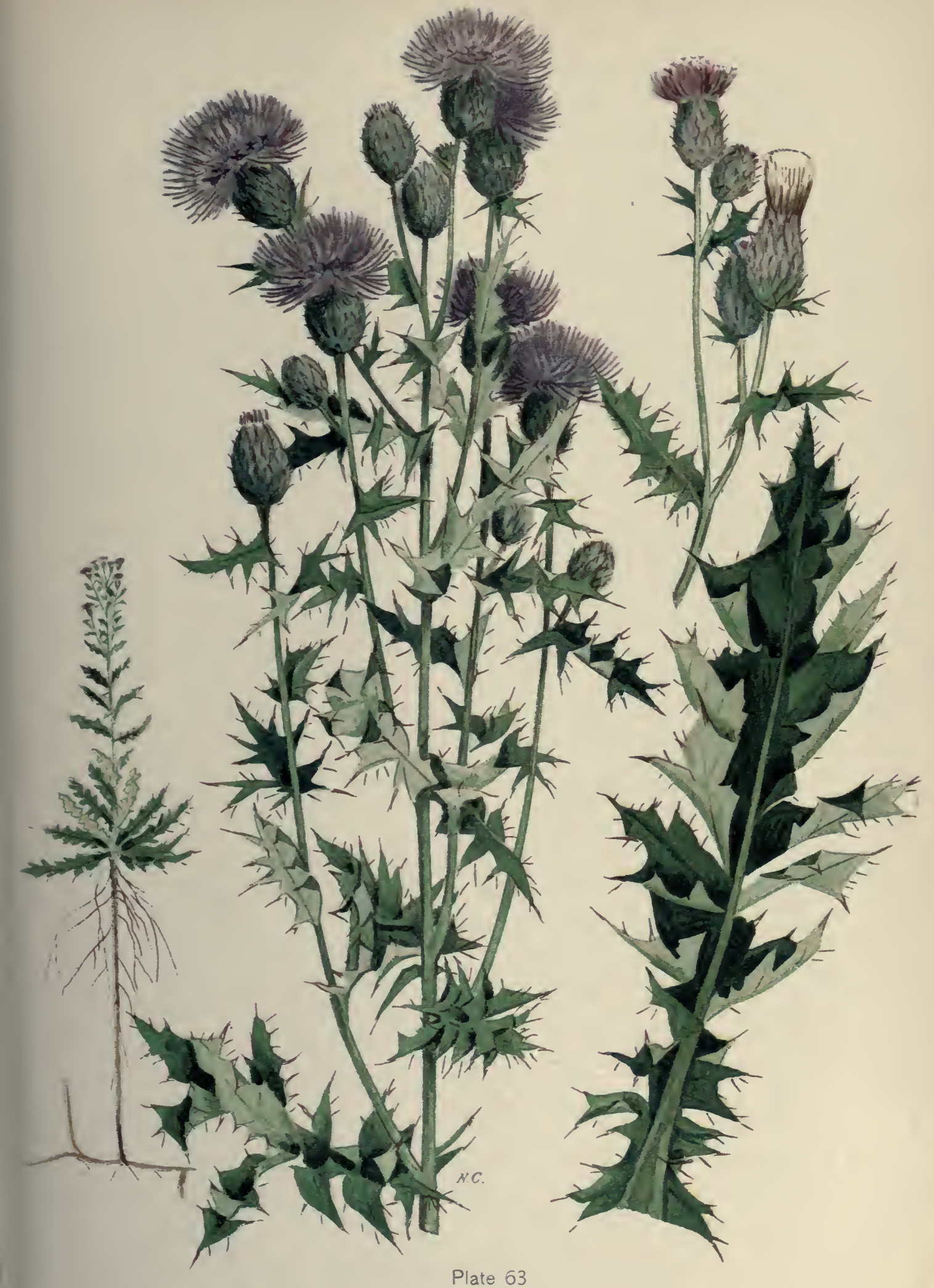

CANADA THISTLE

(Cnicus arvensis Horfm.l 

Occurrence: Abundant in eastern Canada, Manitoba and British Columbia; rapidly spreading in Saskatchewan and Alberta.

Injury: A gross feeder and a vigorous grower, which not only crowds out crops but is conspicuous evidence of negligent farming. The seed is frequently found in grass and clover seeds and in seed oats.

Remedy: Being a deep-rooted perennial, Canada Thistle should be plowed deep in summer, just as the flowers open; or the flowering stems may be mowed down and the land plowed as soon as a new growth appears. As new stems are thrown up they must be cut off with a broad-shared cultivator at intervals through the summer and autumn. Deep plowing late in autumn has been found useful in suppressing thistles in Manitoba.

The chief safeguard against Canada Thistle and all similar deep-rooted perennials is undoubtedly a regular short rotation of crops with thorough cultivation. A three-year rotation, including two cuttings of early red clover for the first year, followed by deep fall plowing for hoed crops with clean cultivation, and a cereal crop for the third year, will suppress it.

ALLIED SPECIES: In addition to Canada Thistle, farmers sometimes complain of two other allied species. Bull Thistle or Spear Thistle (Cirsium lanceolatum (L.) Hill.) is a large, coarse biennial, introduced from Europe, 2 to 4 feet high, widely branching, with many large, deep purple flower heads, $1 \frac{1}{2}$ inches high by as much across. The seed (Plate 76, fig. 88) is similar to that of Canada Thistle, but larger, about 1/6 of an inch long, plumper in proportion to the length, generally darker at the broader end, grayish brown in colour, marked with faint longitudinal lines. It occurs sometimes in seed grain. The treatment given for Lesser Burdock is effective for this weed.

Prairie Thistle or Western Bull Thistle (Cirsium undulatum (Nutt.) Spreng.) is a native perennial with running rootstocks and large, white-woolly leaves and stems; flower heads 
large, nearly 2 inches across, solitary at the end of the branches. The seed is also similar to that of Canada Thistle, but broader, more flattened, about $1 / 3$ of an inch long, highly shiny. This is not a serious pest and soon disappears when the land is put under crop.

Closely allied to these thistles are the Knapweeds (Centaurea). Common Knapweed (Centaurea nigra L.), is rather abundant in meadows in the Maritime Provinces. It is a coarse perennial with thistle-like flowers, over 1 inch across and $1 \frac{1}{2}$ inches high. The calyx-like whorl of bracts surrounding the flower heads is spherical and composed of black-fringed scales.

The seed (Plate 76, fig. 90) is about $1 / 8$ inch long, half as wide, tapering to the base, slightly angular, somewhat flattened and the dark, shining gray surface striped lengthwise with pale ridges; the whole seed is sparsely hairy. The large apical scar covers the whole of the top and is surrounded by a pappus of 2 or 3 rows of short, flat bristles. A characteristic of this seed, is the more or less hooked pointed end bearing the basal scar.

\section{TRIBE CICHORIEAE}

\section{CHICORY (Cichorium Intybus L.)}

Other English names: Wild Chicory, Wild Succory, Blue Sailors.

Introduced from Europe. Perennial from a deep, long, thick root. Stems 2 to 3 feet high, branched, hairy below. Rootleaves closely resembling those of Common Dandelion, 6 to 8 inches long, spreading on the ground, dentate or pinnatifid with the divisions directed backward; midribs hairy beneath; upper leaves glandular hairy on the margins, clasping at base. Flower heads bright blue, sometimes purple or nearly white, about 2 inches across, composed entirely of strap-shaped flowers, usually closing by noon, in stalkless clusters of 3 or 4 together along the almost leafless stems.

The seed (Plate 76, fig. 91) is $1 / 8$ inch long, dark brown or straw-coloured, mottled with brown, wedge-shaped, obtusely 


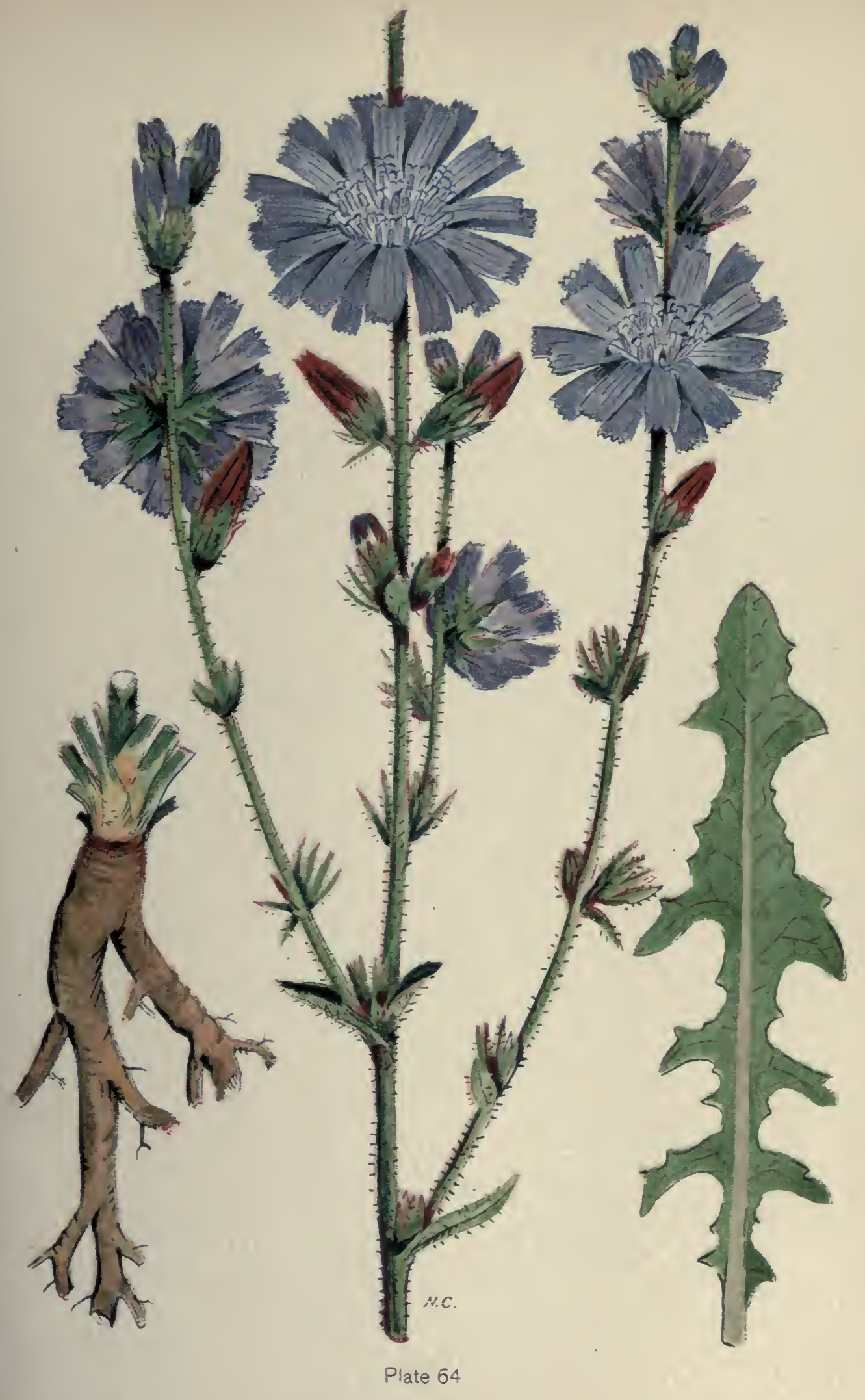

CHICORY

(Cichorium intybus c.) 

3 to 5-angled, sometimes much curved; the surface grooved and ridged from top to bottom and roughened crosswise with minute, close, raised and waved lines; at the top, surrounding the apical scar, is a fringe of short, flat, white bristles.

Time of flowering: July to frost; seeds ripe early in August.

Propagation: By seeds, and shoots which develop from the crown of the roots.

Occurrence: Through eastern Canada, most abundant in Quebec. A common roadside weed and occasionally found in cultivated fields.

Injury: A troublesome weed in rich, low land and in pastures. Seeds often found among crop seeds, particularly in clovers and grasses.

Remedy: Sow clean seed. A short rotation of crops will soon suppress it. Chicory is not often seen in good farming districts except as a wayside weed. Individual plants may be destroyed by close cutting and applying salt to the root in hot, dry weather.

Many report how the Doves make use of vervain, Swallows of Celandine, Linnets of Eye-bright, and Hawks of Hawkweed, for the recovery of their own, and their young one's sight

-William Cole, Adam in Eden, or Nature's Paradise, 1657.

I have not only set the names of Plants and their Vertues but their proprieties also, their Affects and Effects, their Increase and Decrease, their Flourishing and Fading; their Distinct Varieties and several Qualities, so that I may resolve the Reader this much, that though no Art be able to expresse Nature in her likenesse, yet if any Author can with his Pen counterfeit Similitude for Life, shape and shaddowes for substance, he doth to the utmost of his power expresse his Duty. 


\section{FALL DANDELION (Leontodon autumnalis L.)}

Other English names: August Flower, Autumnal Hawkbit, falsely called Arnica.

Other Latin name: Apargia autumnalis Hoffm.

Introduced from Europe. Perennial. Rootstock short and thick, frequently divided into several heads, each of which bears a thick tuft of toothed leaves, some what resembling those of Common Dandelion, and several few-flowered, branched, leafless, scaly stems. Flower heads over 1 inch across, bright yellow.

The seed (Plate 76, fig. 92) is $1 / 4$ inch long, brown, linear, not beaked, ribbed lengthwise, marked with fine lines crosswise; pappus dirty white, in 1 row of feathery bristles, about the length of the seed itself.

Time of flowering: July till frost; seeds ripe by August.

Propagation: By seeds and by division of the crown.

Occurrence: Abundant in the Maritime Provinces and parts of Quebec. Recently reported from several places in Ontario as occurring in hayfields.

Injury: Spreads rapidly from seed and overruns meadows, pastures and lawns, where it chokes out the grass.

Remedy: Fields infested with this weed should be brought under cultivation. It will not give trouble on lands worked under a short rotation, such as cereal grains, clover and grass for two years and hoed crops or peas for the fourth year, followed again by cereal grain. Pasture lands that can not be cultivated may be improved by severely raking the surface with a spring tooth harrow and sowing the most vigorous grasses. It is freely eaten by sheep when their favorite pasture grasses are short.

ALLIED SPECIES: Ox-tongue (Picris echioides L.) is a coarse, rough, bristly perennial with leafy branches, leaves and bracts covered with small bristly spines, flowers yellow. The seed, which occasionally occurs in grass and clover seeds, is cylindrical, about $1 / 10$ of an inch long, reddish brown, contracted to a neck above, and transversely wrinkled. 


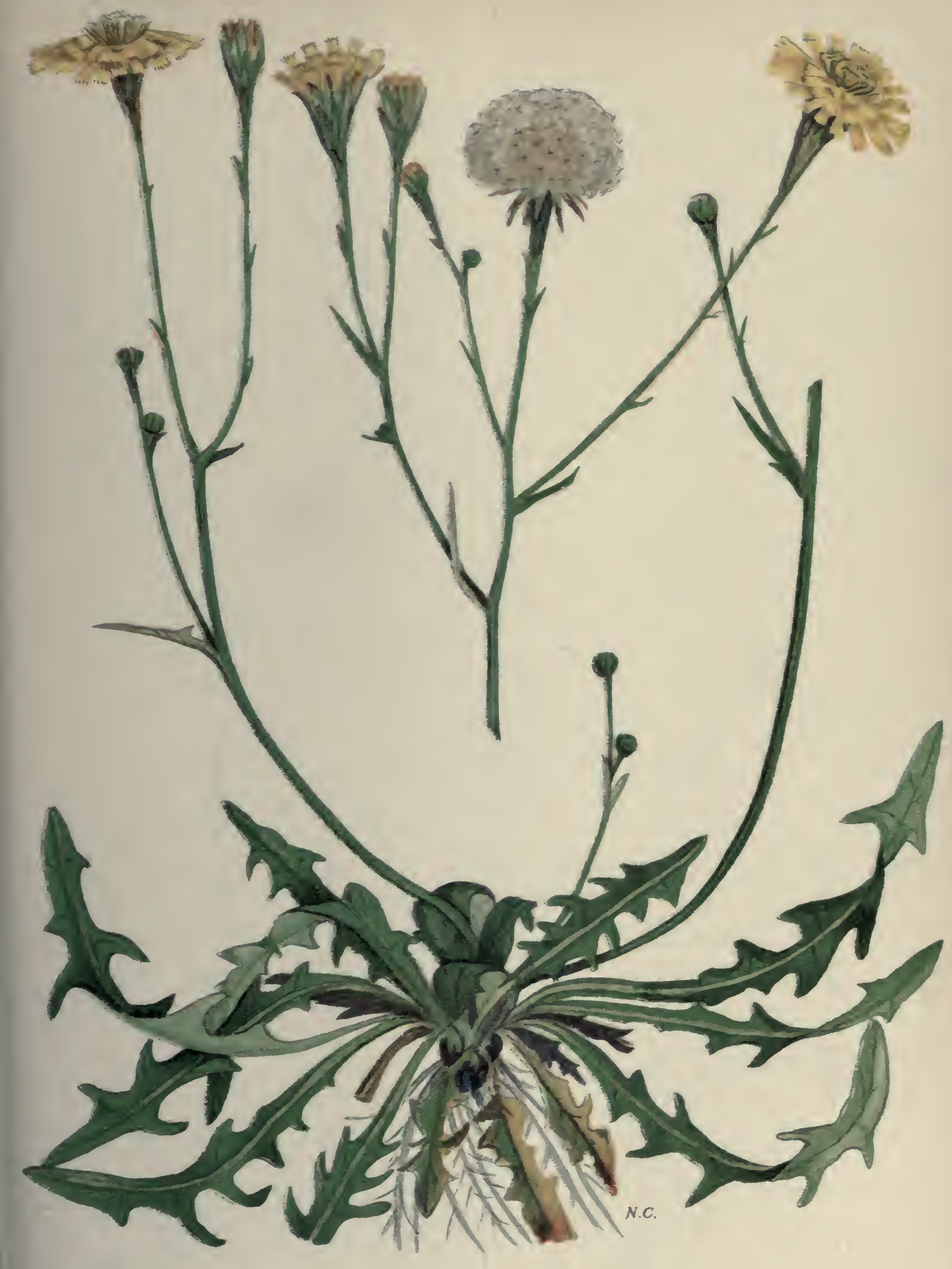

Plate 55

FALL DANDELION AUGUST FLOWER (Leontodon autumnalis $\mathrm{L}$.) 
Salsify (Tragopogon porrifolius L.) and Yellow Goat's Beard (Tragopogon pratensis L.) are common wayside weeds in the eastern provinces, seldom giving trouble in fields. The former is thought to have escaped from cultivation. They may be distinguished by their grass-like clasping leaves and large, solitary heads of yellow or purple flowers, somewhat similar in general appearance to the dandelions.

Common Dandelion (Taraxacum officinale Weber) is a well known pest of all long-settled districts. It differs from Fall Dandelion in having long, deep, tapering roots, every part of which, if broken off, will throw out leaves and form new plants, as well as in having hollow, single-headed flower stalks.

The seed (Plate 76 , fig. 93) is about $1 / 8$ of an inch long, spindleshaped, ridged lengthwise, the ridges roughened with upwardly directed, rigid spines decreasing in size from the top to the base of the seed, where they appear as minute tubercles. The top end of the seed runs into a beak, about $1 / 3$ of an inch long, crowned with a white, thin pappus, $1 / 2$ the length of the beak. This beak breaks off easily and is not present on seeds found in commercial samples.

Red-seeded Dandelion (Taraxacum erythrospermum Andrz.) occurs with the preceding and differs from it merely by having more deeply divided leaves, sulphur-yellow, smaller heads of flowers, and reddish-purple seeds.

It is important to prevent dandelions from seeding in lands adjacent to lawns. Though entailing much labour, the most satisfactory way to deal with them, when deeply rooted in lawns, is to loosen the soil with a digging fork and pull them up. The use of the fork may not be necessary in some wet and soft soils. The application of kerosene to the crown of the plant, in the centre of the rosette of leaves, is recommended. Sulphate of ammonia or sulphate of iron in excess is also recommended. A small tablespoonful of salt applied in the morning of a hot day, when the soil is quite dry, will kill them. 


\section{PERENNIAL SO $W$ THISTLE (Sonchus arvensis L.)}

Other English names: Field Sow Thistle, Creeping Sow Thistle, Corn Sow Thistle (in England), also sometimes incorrectly called Russian Thistle, which, however, is an entirely different plant, described in the Spinach family.

Introduced from Europe. Perennial, deep-rooted, with large and vigorous running rootstocks. Stems 1 to 5 feet high, hollow, simple, with few leaves, and branching at the top. Whole plant filled with a bitter, milky juice. Leaves 6 to 12 inches long, pointed, deeply cut, the lower divisions directed backward, clasping the stem by their heart-shaped base, and edged with soft spines. Flowers bright yellow, $1 \frac{1}{2}$ inches across, in corymbs, closing in strong sunlight; the flower stalk and the scaly bracts surrounding the flower-heads bristly, covered. in the common form, with long, glandular hairs. A perfectly smooth variety is common in parts of New Brunswick and also occurs at Port Hope, Ontario.

The seed (Plate 76 , fig. 94) is about $1 / 8$ inch long, dark reddishbrown, oblong, closely and deeply ridged lengthwise, the ribs wrinkled transversely, giving the seed the appearance of being ridged both ways, bearing at the top a tuft of white, silky and persistent hairs which spread in drying and enable the seed to be carried long distances by the wind.

Time of flowering: June to August; seed ripe by July.

Propagation: Very rapid, by seeds and running rootstocks.

Occurrence: Abundant in cultivated fields and along roadsides, rapidly spreading from the Atlantic Coast to Manitoba; introduced in a few localities from there westward.

Injury: Perennial Sow Thistle, from its exceptionally vigorous running rootstocks and the large amount of seed it matures, is one of our most aggressive weed enemies. It causes enormous loss, both on account of the difficulty of eradicating it and by reducing crop yields. Wherever established, it chohes 
out the crops almost completely. It is much worse in this respect than any of the other thistles. In Manitoba Perennial Sow Thistle is considered the worst of all weed pests; in some cases it has rendered whole fields unfit for grain production. If left undisturbed, its seeds ripen before the grain is cut and are carried long distances by the wind. The seed is sometimes present in clover and grass seeds and seed grain.

Remedy: The fight against this aggressive, pernicous pest will continue indefinitely in localities where it has become established unless extreme measures are taken, and continued from year to year, to prevent it maturing and distributing its seed from waste places and the lands of careless farmers. Every farmer should be sufficiently familiar with this plant to distinguish it from the other sow thistles, as it is a much more dangerous weed. It should be given special attention by municipal governing bodies and weed inspectors.

Small patches may be eradicated by digging out the roots as thoroughly as possible and destroying them. This may have to be done several times during a season. Great care must be taken not to distribute pieces of the rootstalks over the fields by harrows or other implements. To exterminate Perennial Sow Thistle, some system must be adopted which will prevent the development of leaves for a period sufficiently long to kill the roots by smothering them. When a field is badly infested it requires special treatment for a season and close attention for a number of years. One of the most effective methods is to pluw lightly immediately after the hay or grain crop is removed and follow with frequent use of a broad-shared cultivator. Late in the fall plow again, somewhat deeper. In the spring give frequent cultivation, so as to prevent the development of any leaves and thus weaken the roots to the greatest possible extent. About the middle of June or first of July sow rape in drills at the rate of about $1 \frac{1}{2} \mathrm{lbs}$. per acre. Cultivate between the drills as soon as possible and repeat at short intervals until the rape completely covers the ground. Some hand hoeing may be necessary to keep all the thistles down. This should pretty well exterminate the pest but if some plants still remain 
when the rape is cut or pastured off, the field may be fall plowed and put into hoed crop the next season, when special attention can be given to any small patches that may appear. Buckwheat is sometimes used instead of rape for a smothering crop.

In the Prairie Provinces Perennial Sow Thistle can be combatted most effectively by a bare summer-fallow, which should be plowed early and cultivated throughout the season as often as is necessary to keep down all leaf growth. When a field is badly infested it may be necessary to plow again in the fall, give thorough surface cultivation until late the following spring, and sow with oats or barley to be cut green for feed. 'Too much emphasis can not be placed on thorough cultivation, for if this is not given a summer-fallow will merely enable the pest to get a stronger hold.

\section{ANNUAL SOW THISTLE (Sonchus oleraceus L.)}

Other English names: Hare's Lettuce, Colewort or Thistle Milkweed, Milk Thistle, Milky Tassel, Swinies, Common Sow Thistle.

Introduced from Europe. Annual, roots fibrous. Stem nearly simple, 1 to 4 feet high. Leaves deeply cut and toothed with soft spiny teeth; the basal ones pinnatifid, terminated by a large lobe, clasping the stem by their heart-shaped base, ending in sharp points. The flower is pale yellow, about $1 / 2$ to 1 inch in diameter. The scaly bracts surrounding the flower-heads are downy only when young, later becoming hairless.

The seed (Plate 76, fig. 95) is somewhat similar to that of Perennial Sow Thistle but a little shorter, flattened, pointed at the basal end. The longitudinal ridges are wider apart, much finer, and the whole surface of the seed, the ridges as well as the interspaces, is finely wrinkled transversely. Pappus falls off easily.

Time of flowering: May to October; seeds ripe by July.

Propagation: By seeds, which are distributed by the wind. 
Occurrence: Widely distributed throughout eastern Canada and westward to the Prairie Provinces, in fields, gardens and waste places.

Injury: A troublesome weed in cultivated lands. Because of its natural means of distribution, it is difficult to suppress.

Remedy: Prevent it from seeding in waste places by cleaning them up and seeding them to permanent, vigorous grasses. This annual weed, with its relatively small, pale yellow flowers, when compared with the perennial species is not difficult to control by ordinary methods of cultivation and alternation of crops. Sheep, if in sufficient numbers, will prevent sow thistles from seeding in pasture lands.

ALLIED SPECIES: Spiny-leaved or Prickly Sow Thistle (Sonchus asper (L.) Hill.) is an annual of the same habit as Common Sow Thistle. It may be easily identified by its more prickly nature and less deeply cut leaves, the base appendages of which, instead of spreading, are appressed to the stem and rounded.

The seed (Plate 76 , fig. 96) is similar to that of the preceding species in size and shape; distinctly 3 -nerved on each side, with nerves and interspaces quite smooth. Pappus not persistent.

Uncultivated lands, that are often a breeding ground for sow thistles and other weeds, could be made less dangerous by seeding to some vigorous, permanent grass that is able to maintain full possession of the soil.

The thistle proves a great annoyance to some lands by killing the grass corn, etc., although it be a sure token of the strength of the land. The way to destroy them is to cut them up by the roots before feeding time; the advantage you will receive will answer your expense and more. 
PRICKLY LETTUCE (Lactuca scariola L., var. integrata Gren. \& Godr.)

Other English names: Compass Plant or Weed Milk Thistle.

Other Latin name: Lactuca virosa of American authors not L.

Introduced from Europe. Annual, occasionally a winter annual. A coarse, tall-stemmed plant, averaging 3 to 5 feet in height. In British Columbia plants 8 feet high have been found. The leaves are oblong-lance-shaped margined with spines and prickly on the midrib beneath, only the lower ones more or less pinnatifid, stalkless, with ear-like lobes at the base. The leaves of the stem are twisted at the clasping base so as to stand vertically with the edge to the sun, instead of horizontally, as in the case of the leaves of most plants. This peculiarity has given rise to a common name of this lettuce, the Compass Plant. The flower heads are pale yellow, less than $1 / 2$ inch across, on a large, wide-spreading panicle, only a few open at a time.

The seed (Plate 76, fig. 97) is about $1 / 8$ inch long, dark greenishgray, similar to that of the black-seeded varieties of the garden lettuce, usually a little smaller, and, like them, broadly lanceshaped and somewhat curved, flattened, margined and bearing 5 to 7 narrow ridges down each face; whole surface roughened with fine wrinkles, and short, white bristles on the ridges near the apex. The beak widens at the apex and is as long as the seed, very slender and often twisted; pappus white. Both beak and pappus easily broken off by handling the seed.

Time of flowering: July-August; seeds ripe by August.

Propagation: By seeds, which are carried long distances by the wind.

Occurrence: Widely distributed in waste places from Nova Scotia to the Prairie Provinces and reported from parts of British Columbia; sometimes giving trouble in fields. The seed is frequently found among crop seeds. 

Injury: A coarse, weedy plant, often quite prevalent in clover fields and the margins of winter wheat. Like other species of wild lettuce it possesses a narcotic poison, commonly known as lettuce-opium, and is said to be unwholesome to live stock. The plants frequently occur in dense masses, and when young and tender are readily eaten by horses, cattle and sheep. Prickly Lettuce harbours fungus diseases common to cultivated lettuce and some other crops.

Remedy: The seed is short-lived and if the plant is kept closely cut and prevented from seeding in waste places for two or three years it will soon disappear from cultivated areas. Clean waste lands and seed to permanent vigorous grasses. Ordinary methods of cultivation will suppress it in fields.

\section{ALLIED SPECIES: Wild Lettuce or Horse Weed (Lactuca} canadensis L.). A tall annual or biennial weed, hairless, smooth, upper leaves lance-shaped, without any teeth or divisions, lower leaves roundly pinnatifid. Flowers yellow, in open panicles.

The seed (Plate 76 , fig. 98) is about $1 / 6$ of an inch long, broadly ovate, ending in a thin beak, crowned with a silky pappus. Middle rib very prominent. The surface is rough, dark brown, the centre of the seed darker than the wing-like and somewhat radiate margin.

Wherever there are an Abundance of these Thistles, and such other of the rooted Kinds, let the Farmer understand that the Ground will cost him much more Expence than under any other Condition, whatever Method he follows.

一 Thomas Hale, The Compleat Body of Husbandry, 1756.

The putting forth of certain Herbs, discovereth of what nature the Ground where they put forth is; as wild Thyme sheweth good Feeding Ground for Cattel; Bettony and Strawberries shew grounds fit for Wood; Camomile sheweth mellow Grounds fit for Wheat; Mustard-Seed growing after the Plough, sheweth a good strong Ground also for Wheat Burnet sheweth good Meadow, and the like. 


\section{BLUE LETTUCE (Lactuca pulchella (Pursh) DC.)}

Other English names: Showy Lettuce, Large-flowered Blue Lettuce.

Other Latin names: Mulgedium pulchellum Nutt.; Mulgedium acuminatum DC.; Sonchus pulchellus Pursh.

Native. Perennial, deep-rooted. Stems 2 to 3 feet, leafy below. Whole plant smooth and covered with a fine bloom, filled with milky juice. Leaves variable, linear-lance-shaped or oblong; without teeth or divisions, or sometimes dentate or pinnatifid, the divisions directed backward; stem-leaves less divided and stalkless. The flower heads are nearly 1 inch across, pale blue, not very numerous, on scaly footstalks, in a narrow panicle.

The seed (Plate 76, fig. 99) is about $1 / 4$ inch long, including the short, thick beak, the tip of which is whitish, expanded into a short, cup-shaped dise, red when immature, slaty-gray when ripe; club-shaped, flattened with thick ridges down each face; whole surface dull and rough; pappus longer than the seed, pure white and silky.

Time of flowering: June-July; seed ripe by about the end of July.

Propagation: By seeds and fleshy, deep, persistent, running rootstocks.

Occurrence: Throughout the Prairie Provinces and British Columbia; in moist or sandy soil, particularly where there is some alkali.

Injury: A deep-rooted, troublesome weed, having all the bad characteristics of Prickly Lettuce and much more difficult to suppress. 


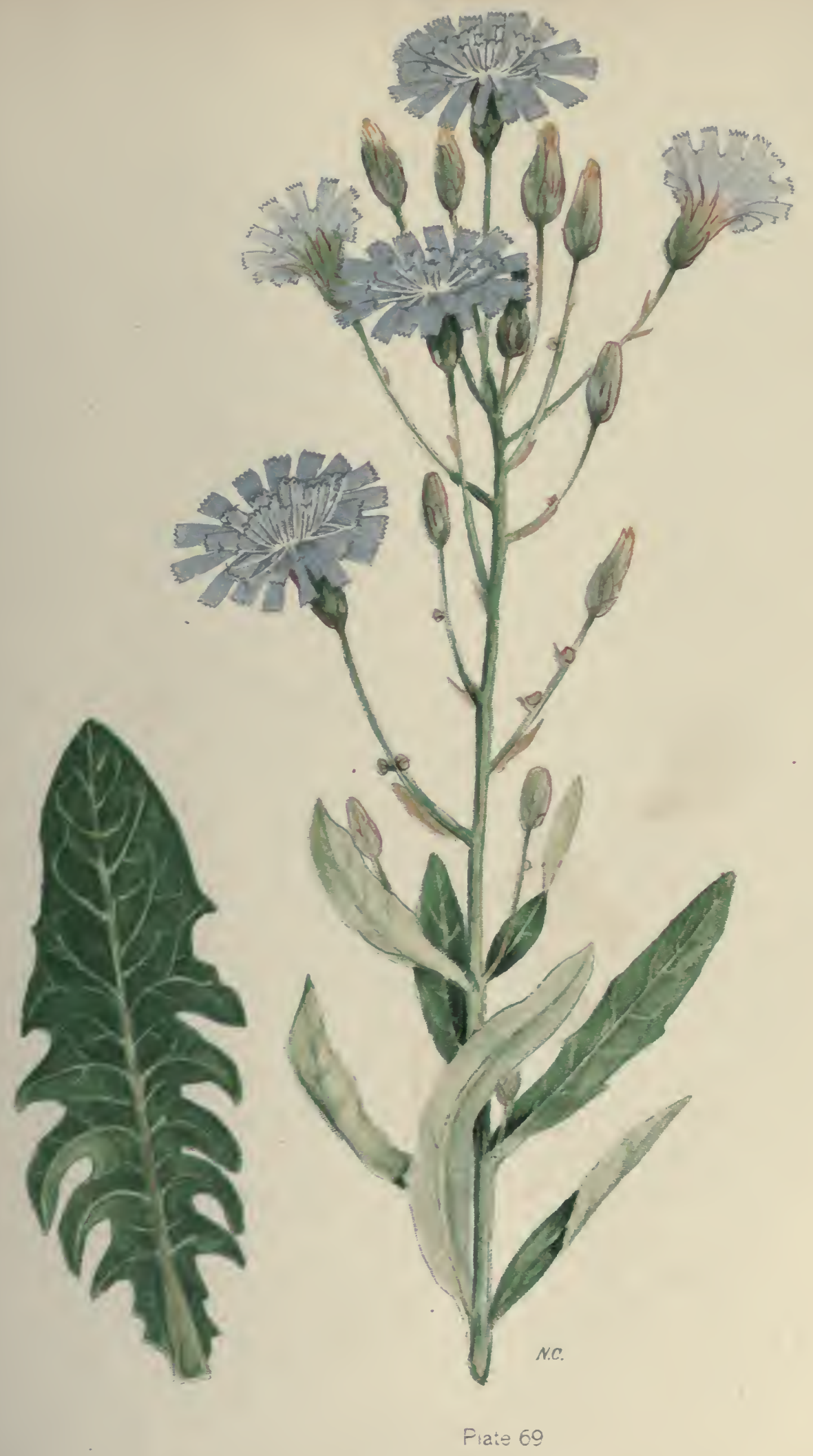

BLUE LETTUCE

(Lactuca pulchella (Pusshioc) 
Remedy: Prevent it from distributing its seeds, by continued cutting along streams, ditches and other waste places. Where this weed is established in fields, a thorough summerfallow, commenced early in the season, with deep cultivation, is advisable. To check this and other weeds having deep, persistent rootstocks, the arrangement of crops should allow thorough cultivation with the disc or broad-shared cultivator before spring seeding, and again in the autunm.

ALLIED SPECIES: Skeleton Weed (Lygodesmia juncea (Pursh) D. Don.) is a native, much-branched perennial, of a rush-like appearance from its almost leafless stems and branches. Leaves linear-lance-shaped, rigid, sharp-pointed, the upper ones nearly reduced to scales. Heads 5-flowered, purplish, solitary at the end of the branches.

The seed is $1 / 6$ of an inch long, slender, slightly tapering, ribbed, crowned with a light brown pappus.

This pest is scarcely less objectionable than Blue Lettuce and should be treated in much the same way. It is more confined to local, relatively moist areas.

If we will plant nettles or sow lettuce, set hyssop and weed up thyme, supply it with one gender of herbs or distract it with many, either to have it sterile with idleness or manured with industry, why, the power and corrigible authority of this lies in our wills.

-Shakespeare, Othello, 1, iii, 1604

Who weeding slacketh,

Good husbandry lacketh.

-Thomas Tusser, Five Hundreth Pointes of Good Husbandrie, 1557.

The farmer, who expects to make profit of his land from what he sows or plants in it, finds not only Herbae inutiles, but also noxiae, unprofitable and hurtful weeds; which come like Muscae, or uninvited guests, that always hurt and often spoil his crop, by devouring what he has by his labour in dunging and tilling, provided for its sustenance. 


\section{ORANGE HAWKWEED (Hieracium aurantiacum L.)}

Other English names: Devil's Paint-brush, Paint-brush.

Introduced from Europe. Perennial, low-growing, throwing out many creeping branches close to the ground. Filled with bitter, milky sap. Whole plant very hairy. Flowering stems 1 to 2 feet, erect and simple, almost leafless, clothed with stellate down, black gland-tipped hairs and long white hairs from black tubercles, bearing at the top a corymb of about a dozen handsome flower heads nearly 1 inch across. The fiery orange-red of the flowers is very striking. Leaves long, rounded at the top, gradually narrowing towards the base or lance-shaped, blunt-pointed, 3 to 8 inches long, tufted, many lying down flat.

The seed (Plate 76 , fig. 100) is from $1 / 16$ to $1 / 12$ of an inch long; purplish-black, unripe seed deep red; linear-oblong, cut off square at the top, pointed at the base, strongly 10-ribbed lengthwise, the tops of the ribs forming a star-like rim around the base of the dusky white pappus, which is not persistent.

Time of flowering: June; seeds ripe by July.

Propagation: By seeds and creeping stems.

Occurrence: Abundant and troublesome in the upland pastures of the Eastern Townships of Quebec and in some places in New Brunswick and Prince Edward Island. Reported occasionally from Ontario and all the eastern provinces.

Injury: A vigorous grower which spreads rapidly by its runners and matures many seeds, by means of which it soon overruns land that can not be plowed, the abundant and useless foliage displacing grass and ruining meadows and pastures.

Remedy: Although a vigorous grower, all the roots are close to the surface of the ground. In land used for crops, plowing down followed by surface cultivation will kill it. Infested meadows and pastures must be broken up and put under a short rotation of crops. For mountain pastures and uplands where plowing is not practicable, small patches may be kept from spreading by applying salt in hot dry weather, at the rate 
of 18 to 20 pounds to the square rod. Infested rocky pastures may be improved by sowing vigorous grasses that are better able to choke out hawkweed than the finer native species.

\section{ALLIED SPECIES: Mouse-ear Hawkweed (Hieracium} Pilosella L.) has been introduced into Prince Edward Island and has taken almost entire possession of some fields and extensive areas along the roadsides. It is an even worse pest than the species mentioned above, as it produces long, running, leafy stems on the surface of the ground, from which tufts of roots and side shoots grow at short intervals, the latter being densely clothed with clusters of leaves, which are smooth above, except for some inconspicuous long white bristles, and covered beneath with a thick felt of star-shaped hairs. The flower heads are solitary, on slender stalks, pale yellow, over an inch across and sweetly scented. The seed is a little longer than that of Orange Hawkweed.

According to Dr. N. L. Britton (Flora of the Northern States and Canada, 1901), the Prince Edward Island Mouse-ear Hawkweed is the variety Peleterianum Mer., of Hieracium Pilosella. The typical form of the species is found occasionally in the other provinces, having been introduced with European grass seeds.

Branching Hawkweed (Hieracium cladanthum Arvet-Touve, MS.) is a persistent perennial occuring in hay meadows and pastures in parts of Quebec and in many places in New Brunswick, Nova Scotia and Prince Edward Island. It is a pernicious and aggressive weed, closely resembling Orange Hawkweed, but having more numerous and rather smaller, pale yellow flowers, narrow and longer leaves, and, in strong plants, tall, flowering stems, sometimes 3 feet high, bearing a large, irregular cluster of flower heads. The lowest branches start below the middle of the stem, but are much elongated and raise their clusters almost as high as those of the upper branches. On weak plants, such as grow in hay fields, this branching habit is less conspicuous and the form more nearly resembles that of Orange Hawkweed. 
KING DEVIL (Hieracium praealtum Gochnat var. decipiens Koch.)

Introduced from Europe. Perennial, with the general characteristics of the hawkweeds. It ${ }^{2}$ bears few leaves, nearly all at the base, and numerous slender, leafy branches running on the surface of the ground. The whole plant is sparsely hairy and lightly covered with a fine bloom. Basal leaves narrow, the long flower stalk bristly hairy, supporting a spreading corymb of yellow flowers.

The seed is similar to that of the other varieties of hawkweeds, a little smaller, black.

Propagation: By runners and seeds which are distributed by the wind.

Occurrence: In the eastern provinces, abundant in southwestern New Brunswick, where it is a pest in pasture lands and old meadows.

Injury: A pernicious weed in pastures. Like the other hawkweeds, it is avoided by stock on account of its pungent flavour and hairy nature. When present in any quantity, it entails much waste of forage or fodder.

Remedy: Grass lands infested with King Devil should be brought under cultivation and a short rotation of crops. It does not long give serious trouble in fields under a rotation of crops that requires frequent plowing. In rocky pastures this pest may be treated the same as Orange Hawkweed.

Most of our hawkweeds are of relatively recent introduction and many varieties have not yet been exactly located and described. Their identity may occasionally prove difficult, as there seem to be variations in the characters of some varieties.

The seeds of the different varieties are practically indistinguishable. They sometimes occur in grass seeds and are a dangerous impurity. The method of eradication is the same for all and consists mainly of a short rotation, with seeding down to clover and grass at short intervals. 



\section{Place 72}

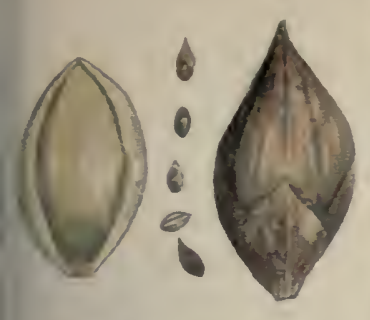

reld Hitidh "Yienss

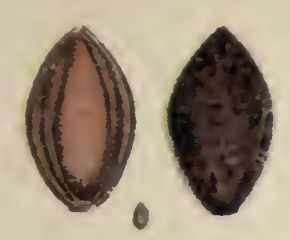

Srean Feastuil

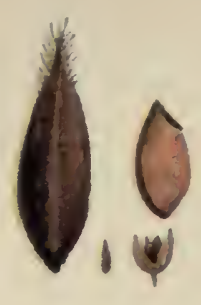

Sheet Srasis
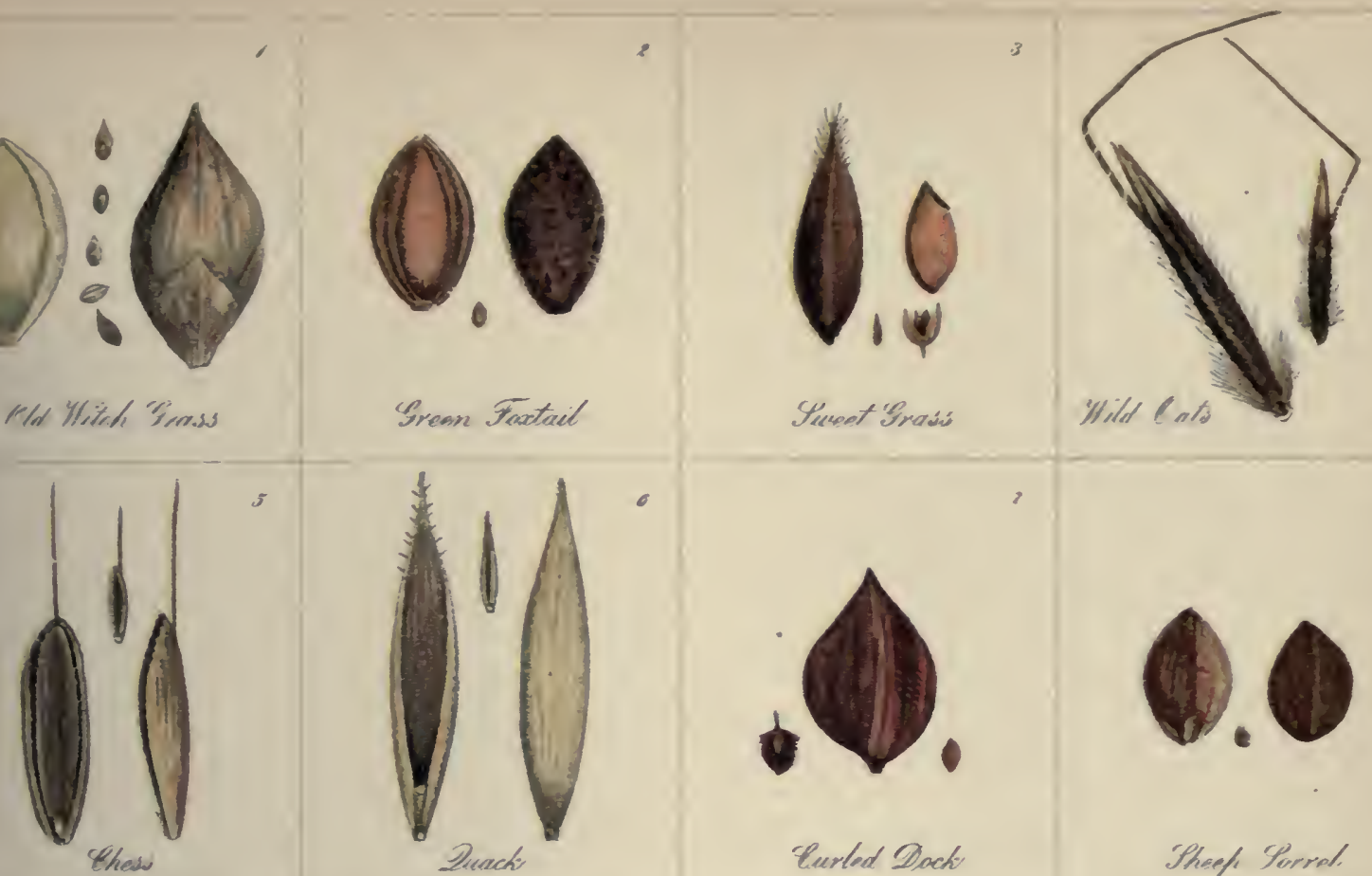

Curlod Dach

Sheef Sorrol.

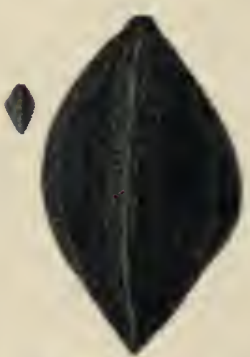

Hild Puchurheat.

Srumbis-yuerters
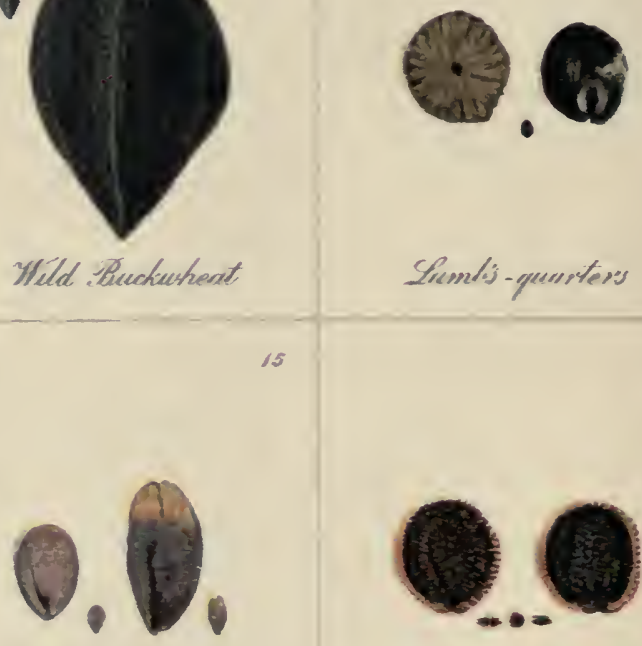

Resseren Promeat

Minsaren. Thialts

Fientreats Higumeat

18

0.8

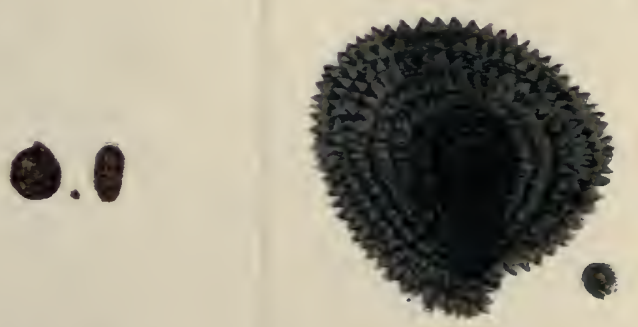

Purple. Euctle

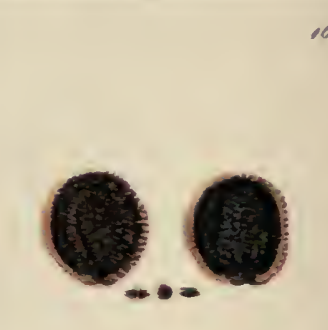

Sperriey

19

20 



\section{Plate 73}

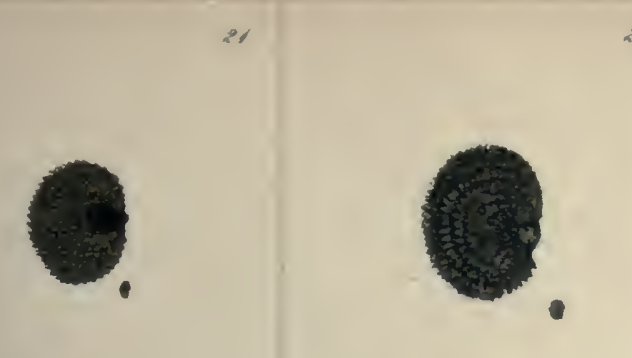

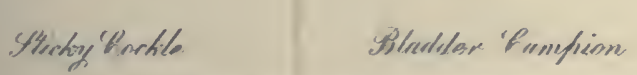

(fone Pontile
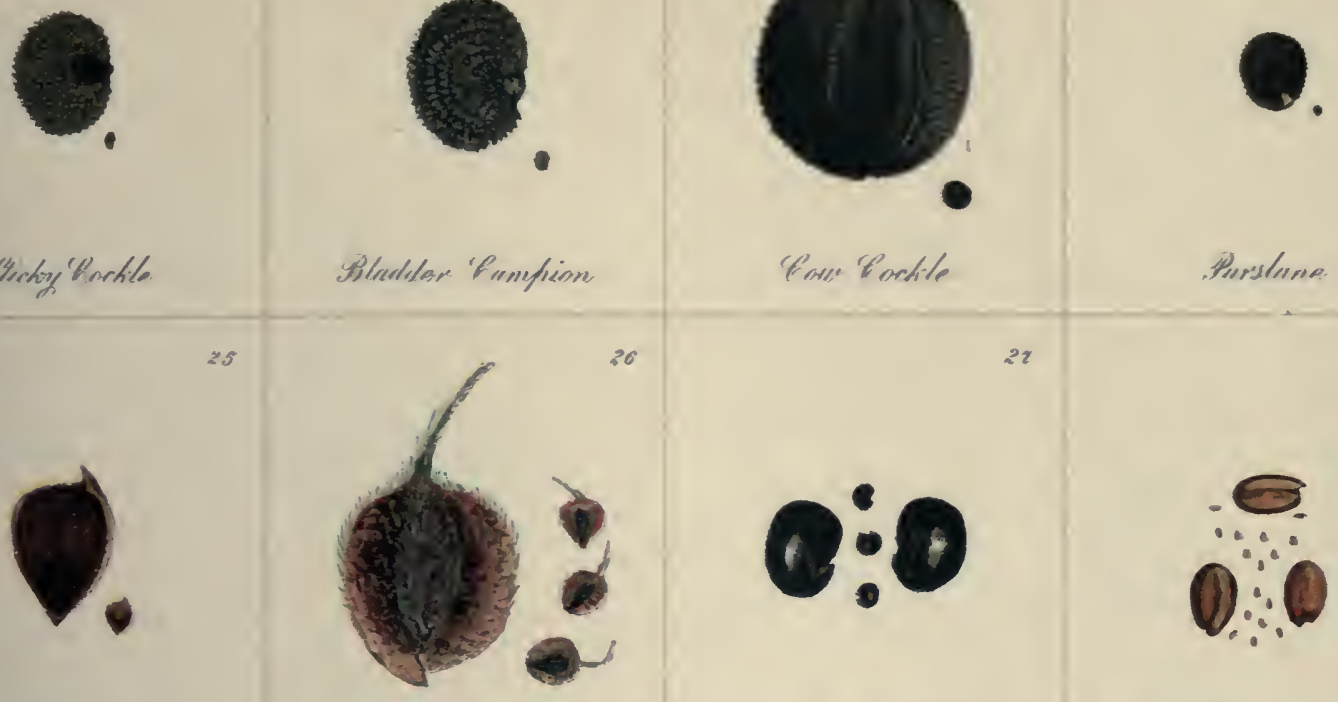

Trell Binttrerceife

White Sherrime.

Goldan Trmitung

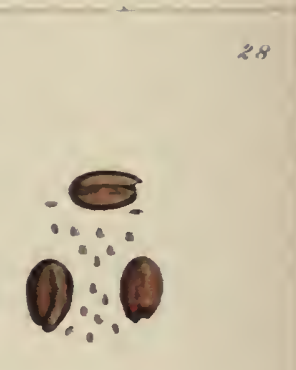

Proselurena

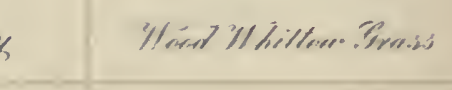

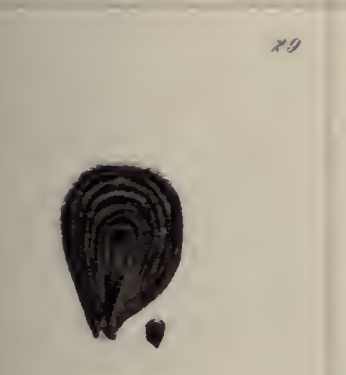

Flunt Whood

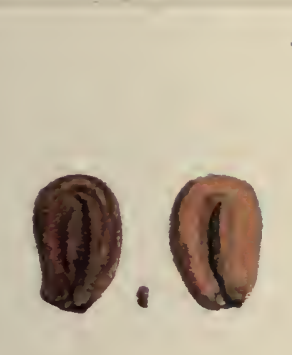

30

Sephiergruas
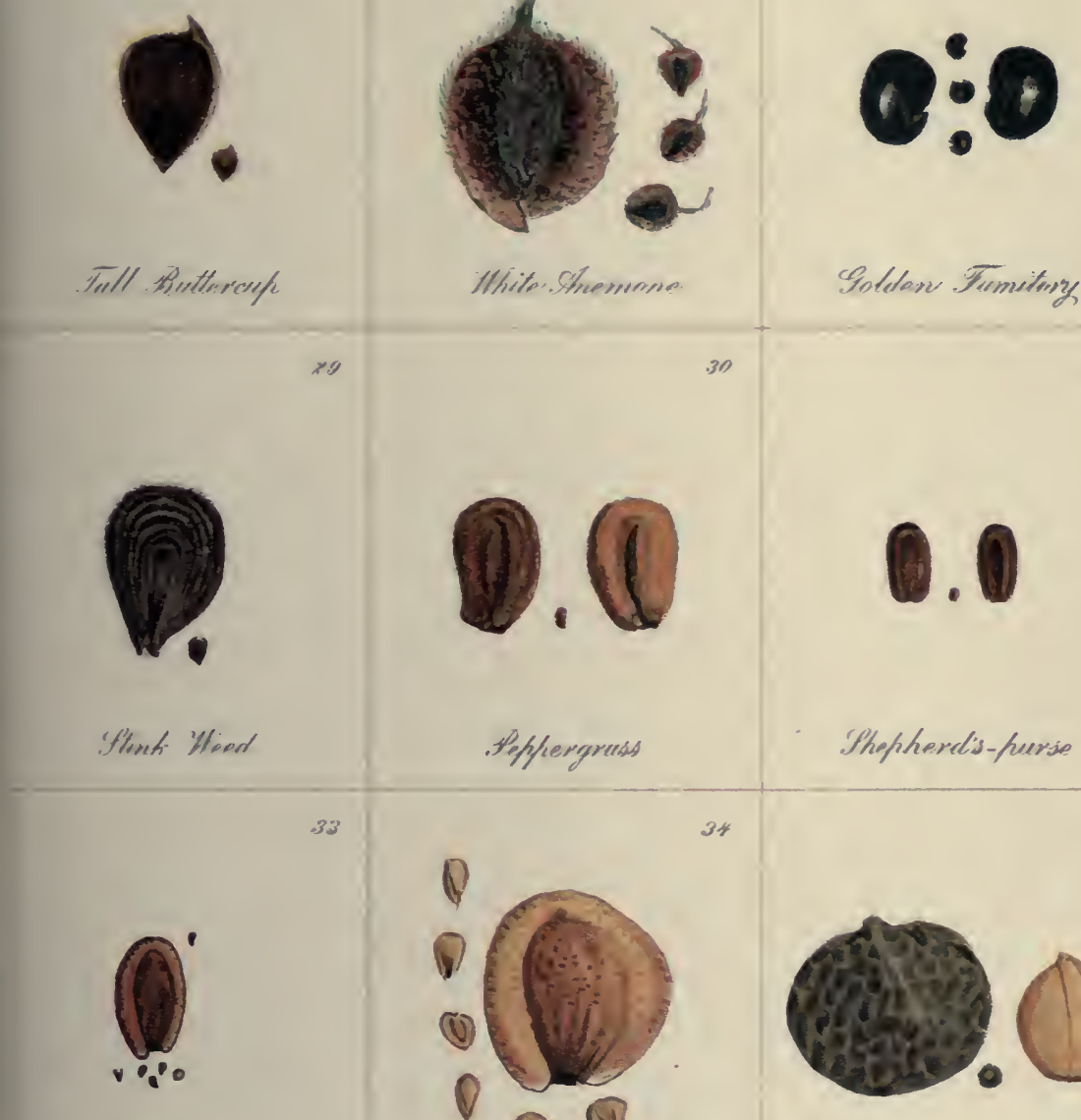

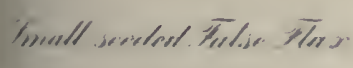

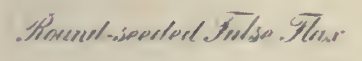

3

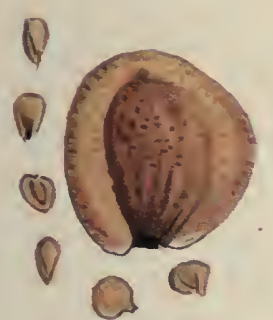

0.0
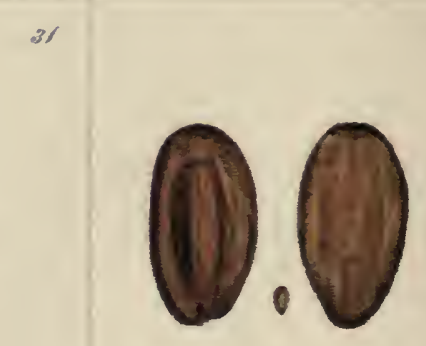

Shopherelis-huerse

False-flinx 



\section{Plate 75}

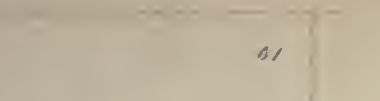

\subsection{0 .0} $y=$

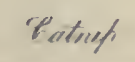

I rnagorretionol

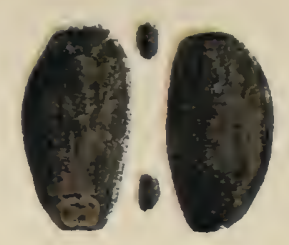

03

of

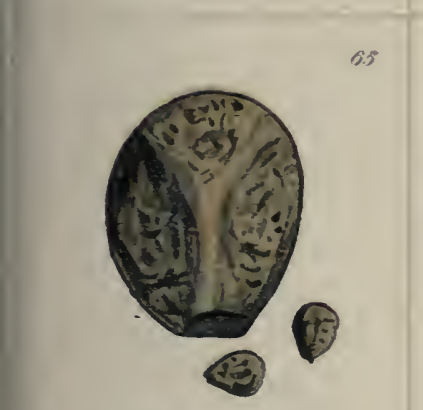

Wormef tirlls

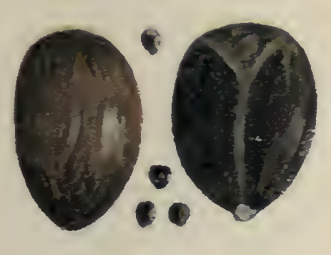

Hislyp Littlo

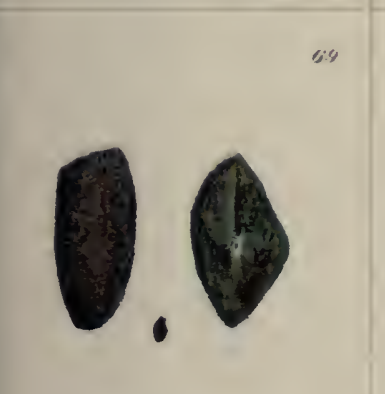

Yiste Plontiuin,
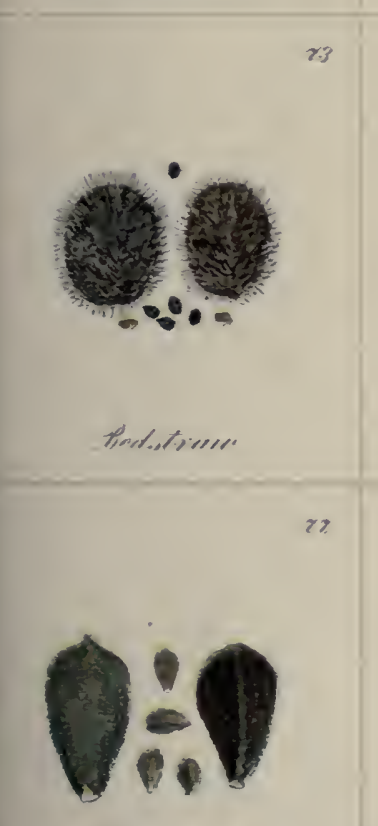

Phimerlly ore wit

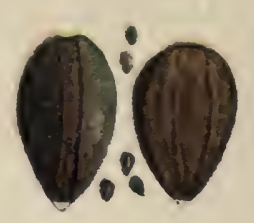

- Heonl all
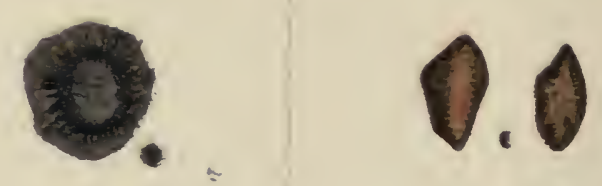

Toartflax.

Common Plantrin

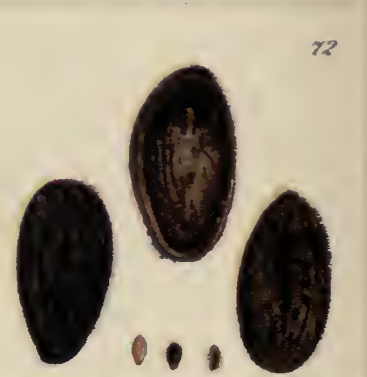

Honasy Plentrint
Pirmeted Plantuin

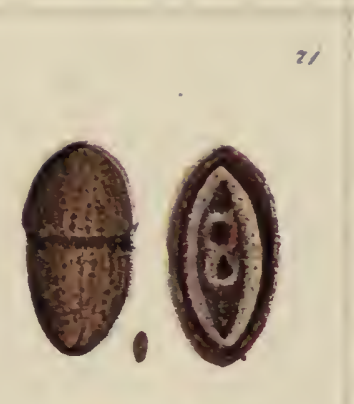

Tymer
Piliyprass 



\section{Plate 76}

\section{$0: 0$}

Yhild Simpltruer

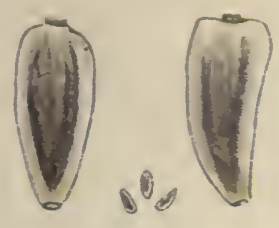

Ifornour

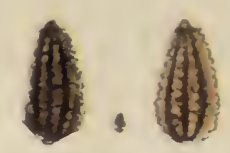

Mloyuceed

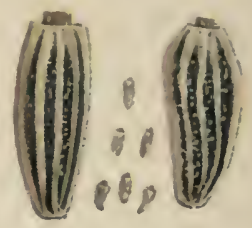

froye Jorizy

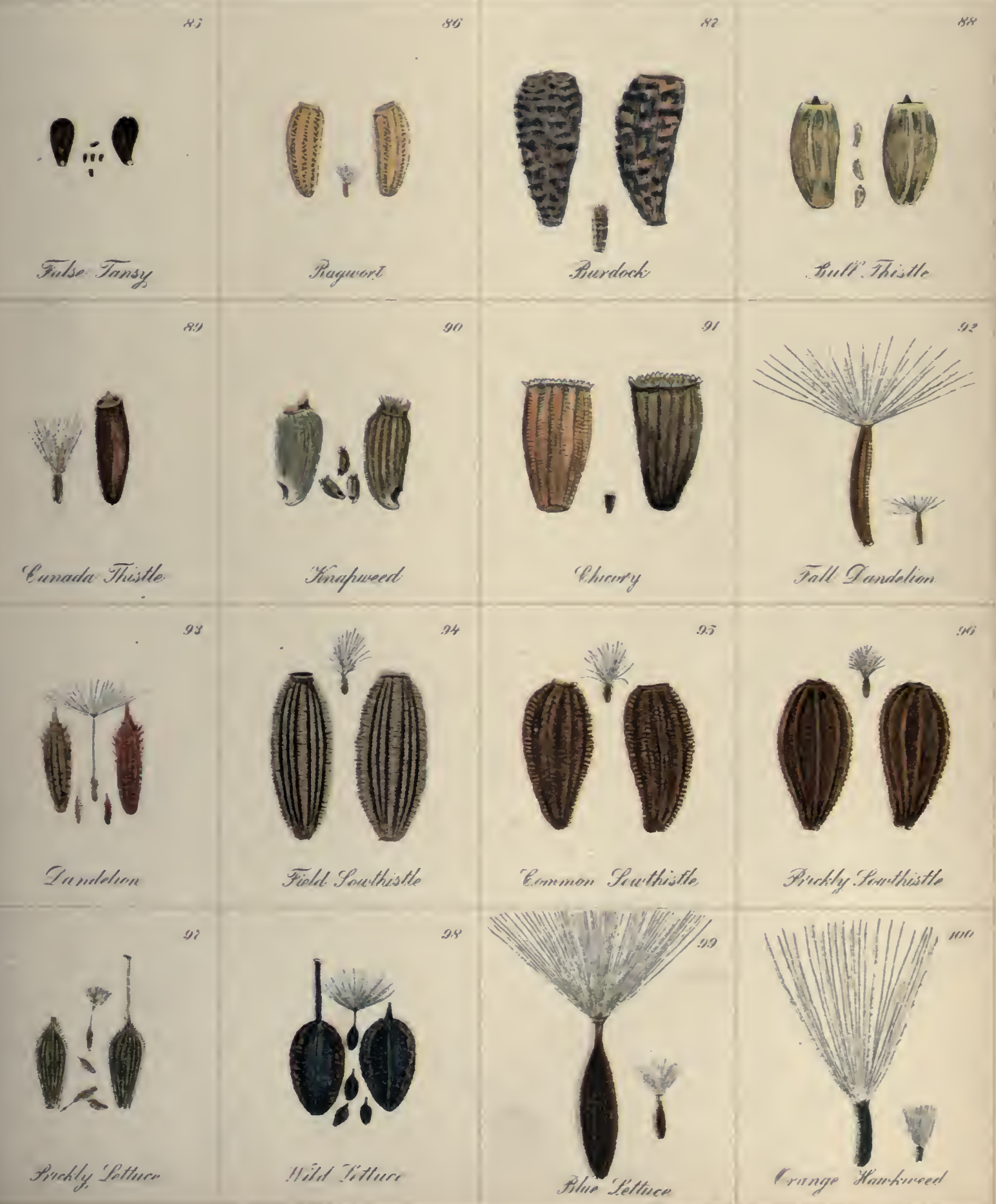


, 
EXPLANATION OF BOTANICAT, TERMS.

Alternate (of leaves, etc.)-Distributed singly at different heights along the stem or branch. Not opposite.

AxNual- See page 11 .

ApICAL SCAR - The mark at the free top end of a fruit, opposite the footstalk.

BASAL SCAR - The mark at the point of attachment of a fruit to its footstalk or of a seed to its vessel.

Biexial- See page 11.

Bract- A more or less modified leaf subtending a flower or belonging to a group of flowers or to the stem.

CALYX- The outer set of leaves composing the flower, generally green in colour.

Capsule- A variety of pod or dry fruit, opening to shed the contained seeds.

CORolla - The inner set of leaves composing the flower, generally coloured.

Conrub- A flat-topped or convex flower cluster, flowering from the margin inward.

Crus- Somewhat similar to corymb, but flowering from the centre outward.

FeMALE Flower-The flower that bears pistils only and produces the fruit and seeds. See "Perfect."

FreE- Separate, not attached or united to similar or other organs.

Fruit- In botany the word fruit signifies the enlarged and matured ovary, (see "Pistil") whatever its substance may be and whether fit to eat or not. In the small fruits of many weeds it is sometimes difficult to decide whether these are fruits or true seeds. In the Buttercup, Sunflower, Borage and Mint families, the seed-like bodies are really fruits, while in the Mustard, Pink, Pea and Evening Primrose families they are true seeds. In describing the weeds in the present publication, it seems wise to speak of all of these as seeds, which is the term commonly used by seedsmen, farmers and others.

HEAD- A dense cluster of flowers with very short or no flower stalks, resting upon the enlarged top end of a common stalk. See "Receptacle." 
MALE FLOWER - The flower that bears only the stamens which contain the pollen. See "Perfect."

Nuthet - A small nut or hard fruit, not opening to shed the contained single seed.

Panicle- A loose, irregularly compound cluster of flowers, borne on flower stalks.

Pappus - See page 141, under Sunflower family.

Perennial- See page 11.

Perfect Flower-A flower that bears both pistils and stamens.

Persistent- Organs remaining attached to those bearing them after the growing period.

PinNatifid (of leaves) - Cut like a feather, from both edges inward to the midrib.

PISTIL- The female organ of the flower, consisting of the ovary, which contains the seed, the stigma, a soft viscid part of the pistil which receives the pollen grains, and the style which supports the stigma.

POD- Any dry fruit, opening by valves, slits, etc., to shed the contained seeds.

RACEME- A cluster of flowers borne upon footstalks of an equal and noticeable length, along a common stalk.

RECEPTACLE - The enlarged top end of a flower stalk or of the footstalk of a flower head. See page 141 under Sunflower family.

REgular Flower-With the divisions of each part uniform in shape and structure.

Rооттоск- A creeping stem below the surface of the ground.

SCALESee page 23, under "The Seed."

SEEDSee Fruit.

STAMFNThe male organ of the flower, composed of the anther, which holds the fertilizing pollen grains, and the support called the filament.

Sike- An elongated flower cluster, with the flowers stalkless or nearly so along a common stalk.

SikELET- See page 23, first paragraph.

TUFted- See page 22, under Grass family.

TAP-ROOT- A generally strong deep root which is the prolongation downwards of the main stem.

Winter Annual-see page 11. 


\section{INDEX.}

\begin{tabular}{|c|c|c|c|}
\hline Plate & Page & Plate & $P_{A G}$ \\
\hline Acalypha virginica. .......... & 110 & Artemisia. . . . . . & \\
\hline Achillea Millefolium. ....... . . & 157 & biennis. ................. & \\
\hline Aconitum............... & 75 & frigida. .............. & \\
\hline Agropyron repens, . ....... 6 & 34 & ludoviciana.............. & \\
\hline $\begin{array}{l}\text { Agropyrum glaucum, var. oc- } \\
\text { cidentale............... }\end{array}$ & & Artichoke, Wild. .......... . . & \\
\hline Agrostemma. . . . . . . . . . . & 59 & ASCLEPIADACEAE... & \\
\hline Githago............. 19 & 64 & Asclepias incarnata. ...... & \\
\hline Alsine media........... 18 & 62 & syriaca. ............. & \\
\hline Alsineae................. & 59 & tuberosa............. & \\
\hline$A M A R A N T H A C E A E \ldots \ldots \ldots$ & 56 & Astereae. & \\
\hline Amaranth, Green.......... . & 57 & Asters. . & \\
\hline$\ldots \ldots \ldots \ldots \ldots \ldots$ & 58 & Astro & \\
\hline n............ & 56 & lex................. & \\
\hline$\ldots \ldots \ldots \ldots \ldots \ldots$ & 58 & August Flower. . ........ 65 & \\
\hline Amaranthus caudatus....... . & 56 & Avena fatua............ 3 & \\
\hline .............. & 58 & var. glabrata.............. & \\
\hline$\ldots \ldots \ldots \ldots \ldots \ldots$ & 58 & glabrescens........... 3 & \\
\hline hybridus............... & 57 & Avicularia............... & \\
\hline $\begin{array}{l}\text { retroflexus. } \ldots \ldots \ldots \ldots \ldots \ldots \\
\text { tricolor. ............... } 16\end{array}$ & $\begin{array}{l}56 \\
56\end{array}$ & Axyris amarantoides. . . . . 14 & \\
\hline Amber.............. 41 & 112 & vulgaris. .......... . & \\
\hline emisiifolia..... 57 & 152 & $\ldots \ldots \ldots \ldots \ldots 62$ & \\
\hline$\ldots \ldots \ldots \ldots \ldots$ & 153 & , Wild........... 7 & \\
\hline$\ldots 56$ & 150 & , Red............ . & \\
\hline Anaphalis.............. & 147 & $\ldots \ldots \ldots \ldots 61$ & \\
\hline Crocus.......... & 75 & den ............. & \\
\hline Pennsylvanian........... & 75 & Beaver Poison. . . . . . . . 43 & \\
\hline White............... & 75 & & \\
\hline Anemone canadensis. . . . . . . . & 75 & BEDSTRAW FAMILY....... & \\
\hline ar. Wolfgangania, . . . & 75 & Bedstraw, Northern. . . . . . . & \\
\hline$\ldots \ldots \ldots \ldots \ldots \ldots$ & 11 & cks. . . . . . . . . . & \\
\hline oallida.......... 42 & 114 & , Common........ & \\
\hline . & 147 & garis. . . . . . . 22 & \\
\hline Anthemis Cotula.......... 59 & 156 & $\ldots \ldots \ldots \ldots \ldots$ & \\
\hline Anthemideae............ & 156 & $\begin{array}{l}\cdots \\
\cdots\end{array}$ & \\
\hline$m$ Linaria........ 50 & 134 & $\ldots 44$ & \\
\hline A pargia autumnalis........ 65 & 168 & Black. ............. 12 & 41, \\
\hline Arabis. ................ & 101 & European. . . . . . . . . 44 & \\
\hline & 101 & Field. . . . . . . . . 44 & \\
\hline Arctium Lappa............. & 163 & Great............... . & \\
\hline minus...... 62 & 162 & Hedge. . .............. & \\
\hline minus.............. 62 & & & \\
\hline Arnica (misnamed)........66 65 & 168 & Upright. ................ . & \\
\hline
\end{tabular}




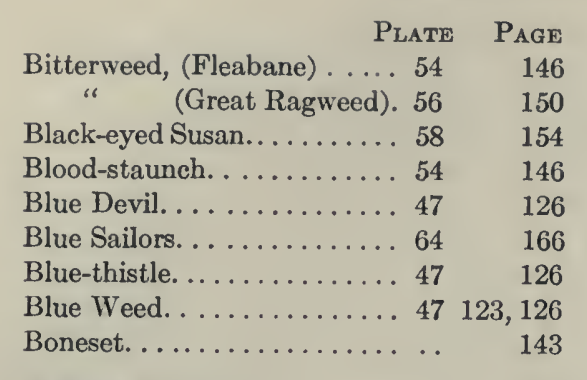

Borage Family............ . 123

BORAGINACEAE........ . 123

Bouncing Bet. ............

Brassica arvensis. ........ 33

campestris.............

juncea.................

Napus. ..............

nigra................

orientalis............ 34

perfoliata............ 34

Rapa.................

Sinapistrum.......... 33

Bromus hordeaceus. . . . . . . . .

secalinus............. 4

tectorum...............

Buckhorn. . . . . . . . . 52

Buckwheat FaMiLY.........

Buckwheat, Wild......... 12

Bugloss, Viper's. . . . . . . . 47

Bur, Blue. ........... 46

Common. ............. .

Sheep................ 46

Burdock, Common. . . . . . . 62

Great. ................ .

Lesser..............6 62

Bursa-pastoris. . . ...... 29

Butter and Eggs........ 50

Buttercup Family. .........

Buttercup, Cursed. .......... .

Meadow.............25

Small-flowered...........

Tall................. 25

Butterfly Weed. . ........... .

Butterweed............ 54

Cabbage, Hare's-ear. . . . . . . 34

Cactus, Russian. . . . . . . . . 15

Cadluck............... 33 .

(misnamed)...... 32
Plate Page

Camelina dentata......... 87

macrocarpa........... $30 \quad 86$

microcarpa........... 87

sativa.............. $30 \quad 86$

Campion, Bladder. ........ $22 \quad 70$

Red................ $\quad 67$

White............ $20 \quad 66$

CAPER FamiLY............. 102

CAPPARIDACEAE....... 102

Capsella Bursa-pastoris. .... $29 \quad 84$

Caraway................. 118

Carex trichocarpa, var. aristata .. $\quad 39$

Carduus arvensis. . .......6 $63 \quad 164$

Carrot, Wild. .............. 118

Carum Carvi.............. 118

CARYOPHYLLACEAE. . . . $\quad 59$

Catchfly, Conical............ $\quad 69$

Garden. ............... . 69

Night-flowering. ........ $21 \quad 68$

Sleepy................ . 69

Small-flowered. . . . . . . . . 69

Catnip................ 130

Cat's-foot. . ............. 147

Celosia................... $\quad 56$

Centaurea................ 166

nigra................ 166

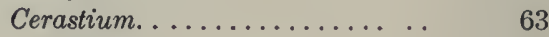

arvense.............. 63

vulgatum............ 63

Chaetochloa viridis. ......... 1

Chamaeraphis viridis....... 1

Chamomile............. $\quad 157$

Dog's. .............. $59 \quad 156$

Charlock ............. $33 \quad 92$

Jointed. . . . . . . . . . . $32 \quad 90$

Cheat............... $4 \quad 30$

Cheeses. .............. 111

CHENOPODIACEAE. .... . 50

Chenopodium............. 50

album.............. $13 \quad 50$

hybridum............ 52

Chess................ $4 \quad 30$

Slender. .............. . 31

Soft................ 31

Chickweed............... $18 \quad 62$

Common. ............ $18 \quad 62$

Common Mouse-car. ....... . . 63

Field, Mouse-ear. . . . . . . . 63 
Chickweeds.

Mouse-ear

Chicory, Family.

Chicory. .............64 64

wild............. 64

Chinaman's Greens. ...... 16

Chrysanthemum Leucanthemum, var. pinnatifidum ... 60

Chrysocoma graminifolia..... 53

Cichoricae.

Cichoriaceae..............

Cichorium Intybus........ 64

Cicuta Douglasii............ .

maculata. ............44 43

occidentalis. .............

ragans................

iirosa, var. maculata. .... 43

Cinquefoil, Rough........ 39

Upright. ............ 39

Cirsium arvense. .........6 63

lanceolatum.............

undulatum...............

Clammy-weed.............. .

Claviceps................

purpurea............ 8

Cleome serrulata. ............

Clotburs. ..................

Clotbur. .............. 62 Spring. ...............

Clover, Rabbit's-foot. . . . . . . .

Stinking ..............

Clovers, Sweet. ............

Clown's Heal. . . . . . . . . . . 49

Cnicus arvensis............ 63

Cockhead. ............. 49

Cockleburs. ...............

Cockle, China............ 23

Corn............... 19

Cow............... 23

Purple............... 19

Sticky. ............. 21

White. ............. 20

Cockles...................

Cockscombs. .............

Colewort. .............67 67

Colt's-tail. .............. 54

Compass Plant.......... 68
COMPOSITAE...........

141

Composites, Strap-flowered. . . .

Tube-flowered ...........

Cone Flower. ............ 58

Conringia orientalis....... 34

CONVOLVULACEAE.....

Convolvulus Famil. . . . . . .

Convolvulus arvensis. . . . . . 44 sepium................ spithamaeus. ............

Coris. ............... 54

Corydalis aurea. . .......... .

Cowbane............... 43

Spotted.............4 43

Cow-bell. . . . . . . . . . 22

Cowherb. ............. 23

CRASSULACEAE........ 103

Cress, Cow............... . 83

Crowfoot, Ditch........... . 77

Tall. .............. $25 \quad 76$

Crownweed........... $56 \quad 150$

CRUCIFERAE.......... 77

Cucubalus Behen.......... $22 \quad 70$

Cuscuta................. 123

Epithymum..........4 $45 \quad 122$

Trifolii............45 122

Cuscuteae............... 120

Cutweeds .............. 147

Cynareae............... 162

Cynoglossum officinale. ........ 124

CYPERACEAE......... $\quad 39$

Cyperus diandrus............ $\quad 39$

esculentus. ............ $\quad 39$

Daisy, Ox-eye. . . . . . . $60 \quad 158$

Ox-eye (misnamed)...... $58 \quad 154$

Orange............... $58 \quad 154$

White. .............6 $60 \quad 158$

Yellow.............. $58 \quad 154$

Dandelion, Common......... . 169

Fall..............65 $65 \quad 168$

Red-seeded............ $\quad 169$

Darnel, Bearded......... $5 \quad 32$

Common............. $5 \quad 32$ 


\begin{tabular}{|c|c|c|c|c|c|}
\hline & Plat & PAGE & & Plate & $P_{A G}$ \\
\hline Poison. . & 5 & 32 & EUPHORBIACEAE. & . . & 11 \\
\hline White............... & 5 & 32 & & & \\
\hline Daucus Carota. . .......... & .. & 118 & $\begin{array}{l}\text { Eupnorona corollaza. .. } \\
\text { alyptosperma. }\end{array}$ & $\cdots$ & \\
\hline Delphinium. ............. & . & 75 & $\begin{array}{l}\text { glyposperma.. } \\
\text { Helioscopia. . }\end{array}$ & $\cdots$ & \\
\hline Digitalis. . .............. & . & 133 & maculata. ... & & \\
\hline Dock, Bitter. ............ & .. & 43 & Euphrasia arctica.... & & \\
\hline Clustered.............. & -. & 43 & Euthamia graminifolia. . . & $\ddot{53}$ & \\
\hline ............. & - 9 & 42,43 & & & \\
\hline$\ldots \ldots \ldots \ldots \ldots \ldots$ & 9 & 42 & Evening Primrose Family.. & . $\cdots$ & \\
\hline Veiner & 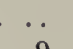 & 43 & Evening Primrose, Common.. & & \\
\hline$\ldots \ldots+\cdots \cdots \cdots$ & 9 & 42 & White. .................... & 42 & \\
\hline Docks. . ................ & ... & 40 & White-stemmed. . & 42 & \\
\hline Dodder, Alfalfa. .......... & 45 & 123 & Everlastings........ & 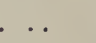 & \\
\hline r. . . . & $\begin{array}{l}45 \\
45\end{array}$ & 122 & True................ & & \\
\hline . $\cdots \cdots \cdots \cdots \cdots \cdots$ & $\begin{array}{l}45 \\
45\end{array}$ & 2 & Explanation of Botanical & & \\
\hline …....... & $\begin{array}{l}45 \\
. .\end{array}$ & & Terms............... & .. & \\
\hline $\begin{array}{l}\ldots \ldots \ldots \ldots \cdots \\
\cdots \ldots \ldots \ldots \ldots\end{array}$ & $\ddot{59}$ & 120 & Eyebright, Glandular . . . . . . & . & \\
\hline$\ldots \ldots \ldots \ldots$ & - $\ldots$ & 41,47 & & & \\
\hline iniana. . . . . . . . . & & 79 & d-seeded.. & 30 & \\
\hline nem & 26 & 78 & Small-seeded.............. & $\begin{array}{l}\cdots \\
\cdots\end{array}$ & \\
\hline & & 79 & Farm Implements to Destroy & & \\
\hline lum parviflorum. . & $\therefore$ & 131 & Weeds. .................. & & \\
\hline L, American....... & . . & 131 & Fat-hen. . . . . . . . . & 13 & \\
\hline$\ldots \ldots \ldots \ldots \ldots$ & .. & 67 & & & \\
\hline Drummond's Pink. ......... & . & 67 & FIGWORT FAM & .. & \\
\hline mum Lappula. . . . & 46 & & Figworts. & . & \\
\hline$\ldots \ldots \ldots \ldots$ & . & & Fireweed. . . & & \\
\hline …......... & 47 & 126 & Fleabane) & 54 & \\
\hline Bacon........... & 50 & 134 & “ (Great Willow-herb) & $\ldots$ & \\
\hline$\ldots \ldots \ldots \ldots \ldots$ & -. & 147 & Sticky............... & . . & \\
\hline ............ & . & 113 & eeds. . . . . . . . . . & . & \\
\hline$\ldots \ldots \ldots$ & .. & & & & \\
\hline$\ldots \ldots \ldots \ldots$ & . & & . & 50 & \\
\hline Erechtites hieracifolia........ & & 162 & Fleabane, Common........ & 54 & \\
\hline Ergot on Couch, Rye and & & & 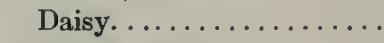 & & \\
\hline Timothy. ........... & - 8 & 38 & Rough Daisy. . . . . . . . . & . & \\
\hline Erigeron annuus........... & & 146 & Foxglove. .............. & & 13 \\
\hline .......... & 54 & 146 & Foxtail, Green. . . . . . . . . . . & 1 & \\
\hline n.w. & .. & 147 & .......... & & \\
\hline$\ldots \ldots \ldots \ldots \ldots$ & .. & 94 & 1 (misnamed). . . . & 7 & \\
\hline Erysimum, Small.......... & .. & 101 & French Weed. . . . . . . . . & . 27 & \\
\hline asperum..... & 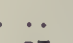 & 101 & & & \\
\hline cheiranthoides............ & - 37 & 100 & FUMARIACEAE. . . . . & & \\
\hline 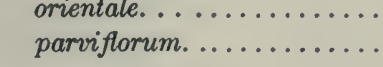 & $\begin{array}{l}34 \\
. .\end{array}$ & $\begin{array}{r}94 \\
101\end{array}$ & Fumitorx Family. . . . . . . & . & \\
\hline Eupatorieae. & & 142 & $\begin{array}{l}\text { ory, Golden. .......... } \\
\text { sis Tetrahit......... }\end{array}$ & $\ddot{48}$ & \\
\hline erfoliatum. & .. & 143 & & ... & \\
\hline & & & & & \\
\hline urticaefolium. & & 143 & Galium boreale. . . . . . . . & . & \\
\hline
\end{tabular}


Plate Page

General Principles.......... .

Glycyrrhiza lepidota...........

Gnaphalium.............

Goat's Beard, Yellow.......... .

Gold of Pleasure......... 30

Goldenrod, Bushy........ 53

Canada.................

Fragrant............ 53

Narrow-leaved.........53

Smooth................

Tall...................

Tall Hairy............. .

Golden Jerusalem. . . . . . . 58

Goosefoot FAMILY...........

Goosefoot, Maple-leaved..... . .

White.............. 13

GRAMINEAE.......... 22

Grass FaMILY............ 22

Grass, Blue Joint.......... . . 35

Bottle.............. 1

Couch.............. 6

" (misnamed)...... 2

Holy............... 2

Old-witch..............

Panic. ................. .

Pigeon.............. 1

Poison rye........... 5

Poverty...............

Quack............. 6

" (misnamed)...... 2

Quitch.............. 6

Scutch............. 6

Seneca.............. 2

Skunk.............. 7

Skunk-tail........... 7

Squirrel-tail.......... 7

Sweet............. 2

Tickle............ 7

Twitch............. 6

Vanilla.............. 2

Vernal..................

Western Couch............

Whitlow, Carolina ........

Wood............ 26

Yellow. . . ....... 26

Grindelia squarrosa. .........

Gromwell, Corn. ............

Field................

Groundsel, Common..........

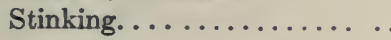

Gum Plant Plate Page

Gumped . .............. 143

Hardhack. . . . . . . . . . . $38 \quad 104$

Hawkbit, Autumnal. ......... 168

Hawkweed, Branching. ..... . . 179

Mouse-ear.............. 179

Orange............. $70 \quad 178$

Heal-all................ 131

Heliantheae ............ 148

Helianthus doronicoides. ... . . . 155

Maximitiani............ 155

scaberrimus............. 155

Helenieae............. 155

Helenium autumnale. ........ 155

Hemlock, Water......... $43 \quad 116$

Oregon......... 117

Purple-stemmed .. 117

Wyoming........ 117

Hemp, Bastard. . . . . . . . $48 \quad 130$

Herb-John. . . . . . . . . $41 \quad 112$

Herrick. ............. $33 \quad 92$

Hieracium aurantiacum. . . . $70 \quad 178$

cladanthum............ 179

Pilosella............... 179

var. Peleterianum........ 179

praealtum, var. decipiens.. $71 \quad 180$

Hierochloa borealis........ 226

Hierochloè odorata. ....... 2

Hogweed............. $57 \quad 152$

Holcus odoratus. ......... 2

Hordeum jubatum........ 7

Hòrsehead............... 147

Horseweed............. $54 \quad 146$

Horse Weed.............. 175

Hound's Tongue. . . . . . . . . . 124

HYPERICACEAE........ 112

Hypericum Ascyron. ......... 113

ellipticum............. 113

perforatum............41 112

punctatum............. 113

Indian Hay............ 2

Inula Helenium. . . . . . . . 147

Inuleae................ 147

Ironweeds. ............... 142

Iva axillaris. . . . . . . . . 5j 148 xanthifolia............. 149

Ivray............... $5 \quad 32$

Ixophorus viridis. . . . . . . 1 


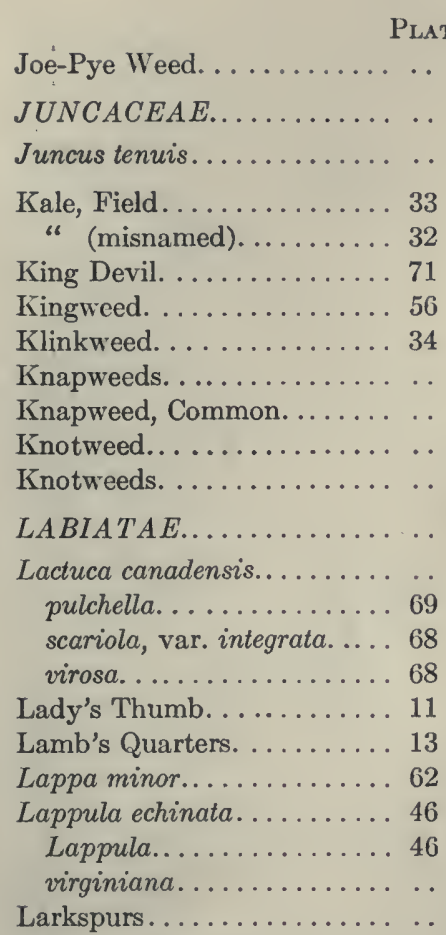

LEGUMINOSAE. ......... .

Leontodon autumnalis. . . . . 65

Lepidium apetalum. . . . . . 28 campestre.............. intermedium.......... 28

Leptilon Canadense. . ...... 54

Lettuce, Blue.......... 69 Large-flowered . 69 Hare's. . . . . . . . . . . . . 67 Prickly............ 68 Showy ............ 69

Wild.................

Leucanthemum vulgare. . . . 60

Liguliflorae. .............. .

Linaria Linaria........... 50 vulgaris. ............ 50

Liquorice, Wild. ........... .

Lithospermum arvense. ..... . .

Live-for-ever. . . . . . . . . . .

Loco Weed................ .

Loco Weeds .............. .

Lolium arvense. .......... 5 temulentum........... 5

Love-lies-bleeding. .......... .

Love Vine. ............ 45
PAge

142

40

40

92

90

180

150

94

166

166

47

40,41

129

175

176

174

174

41,46

50

162

124

124

125

75

107

168

82

83

82

146

176

172

176

174

176

175

158

142

134

133-4

108

127

103

108

107

32

32

56

122
Plate Page

Lychnis, Evening. . . . . . 20 20

Lychnis alba. . . . . . . . . 20 $20 \quad 66$ chalcedonica........... 67 coronaria................ 67 dioica............... $\quad 67$

Drummondii........... $\quad 67$

Flos-cuculi........... . 67

Githago............. $19 \quad 64$

vespertina........... $20 \quad 66$

Lygodesmia juncea........... . 177

Madder Family........... 140

Madder. Field.............. . . 140

MaLLOW FAMILY . .......... 111

Mallow, Common. .......... . 111

Common Round-leaf. ....... . 111

MALVACEAE.......... 111

Malva rotundifolia........... 111

Mare's-tail............. $54 \quad 146$

Marigold, Bur............ 155

Marsh-elder, Small-flowered. . $55 \quad 148$

Maruta Cotula. ......... $59 \quad 156$

Matricaria inodora.......... . $\quad 157$

Mayweed............ $59 \quad 156$

Scentless. .............. 157

Stinking. . . . . . . . . . $59 \quad 156$

Meadow Sweet............ 105

Medicago arabica........... 108

hispida.............. 108

lupulina.............. 108

Medick, Black. ........... 108

Spotted................ 108

Toothed................ . 108

Melandrium noctiflorum.... $21 \quad 68$

Melilotus alba.............. 107

officinalis. . . . ........ 107

Mercury, Three-seeded....... . 110

Milfoil. .............. 157

Milkweed Family. . ....... . 119

Milkweed, Common. . . . . . . . . 119

Swamp.............. 119

Thistle............67 $67 \quad 172$

Milkweeds .............. 119

Milky Tassel. ............. 172

Mint Family. ............. . 129

Mint, Hairy. . . . . . . . . . . 49

Monkshoods. ........... . 75

Monning Glory Family. . . . . 120

Morning Glory, Small-flowered $44 \quad 120$ 


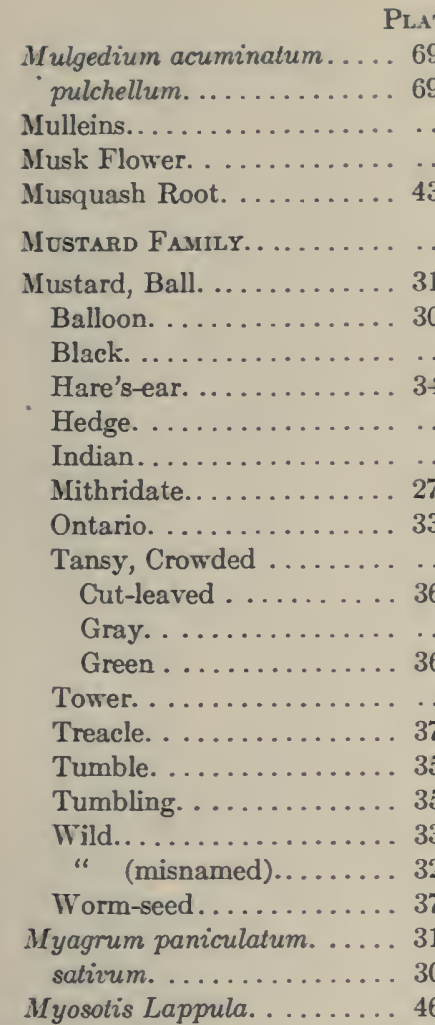

Nepeta Cataria. ............. .

Neslia. . . . . . . . . . . . . 31

Neslia paniculata. ........ 31

Nettle, Bee............ 48

Blind............. . 48

Dead. .............. 49

Dog. . . . . . . . . . . . 48

Hedge. . . . . . . . . . . . 49

Hemp. . . . . . . . . . . 48

Dead ............ 48

Stinging............ 48

Nettle-wild............ 48

Nigger Head............ . 58

Nutgrass..............

Oats, Wild. ............ 3

Odontites rubra. .............

Oenothera albicaulis. ........ 42

biennis. ..............

pallida.............. 42

ONAGRACEAE..........

OrPine FaMily.
PAGE

176

176

133

133

116

77

88

86

93

94
Plate Page

Ox-tongue.............. 168

Oxytropis............... 107

Lamberti.. . . . . . . . . . . . . 108

Paint-brush............70 $70 \quad 178$

Devil's............. $70 \quad 178$

Panicum................ 25

capillare................. 25

viride.............. 1 24

Parsley FaMily. .......... 115

Parsnip, Water (misnamed) . .. 116

Wild.................. 118

Pastinaca sativa........... 118

Pea Famly.............. 107

Pea, Wild.............44 408

Penny Cress. ............ $27 \quad 80$

Penny-John. ...........41 412

. Peppergrass............ $28 \quad 82$

Field............... 83

Perennials............... 11

Persicaria. .............. 41

Persicary............. $11 \quad 46$

Dockleaved............ $11 \quad 47$

Glandular. ............. 47

Pale.............. $11 \quad 47$

Pickpurse............ $17 \quad 60$

Picris echioides . . . . . . . . . . 168

Pigeon Weed. . . . . . . . . . . 127

Pigweed Family. .......... 56

Pigweed............. $13 \quad 50$

Redroot. ........... $16 \quad 56$

Rough............. $16 \quad 56$

Russian. ............ $14 \quad 52$

Pink Family. ........... 59

Pitch-forks. ............. 155

PLANTAGINACEAE....... 135

Plantago aristata. .......... 139

lanceolata............ $52 \quad 138$

major............. $51 \quad-136$

media................ 139

Rugelii. ............ 137

Plantain Famur........... 135

Plantain, Birdseed........ $51 \quad 136$

Bracted. .............. . 139

Broad-leaf. ........... 51 136

Common. ........... $51 \quad 136$

Dooryard. . . . . . . . . $51 \quad 136$

English. .......... $52 \quad 138$ 


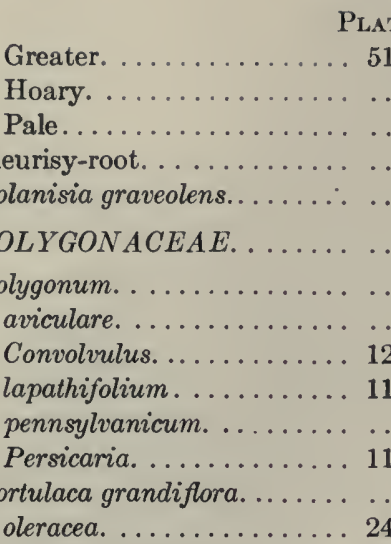

Portulaca, Wild. ......... 24

PORTULACACEAE........ .

Potentilla................ .

Anserina .............. .

hirsuta.............. 39

monspeliensis. ........ 39

var. norvegica ..........

Poverty Weed. . . . . . . . . . 55

Prideweed.............. 54

Prunella vulgaris. ...........

Purslane Family. ..........

Purslane. ............... 24

Milk. .................

Pusley................. 24

Rabbit-ear............. 34

Radish, Jointed. . . . . . . . . 32

Wild............... 32

Ragged Robin. ............

Ragweed, Common........ 57

False. ...............

Great. ............ 56

Perennial..............

Smaller. . . . . . . . . . 57

Tall. .............. 56

Ragwort, Common. .......61

Tansy. . . . ........6 61

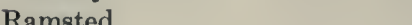

RANUNCULACEAE. . . . . .

Ranunculus abortivus. . .......

acris. .............. 25

sceleratus. .............

Rape. ................

Bird . . .............

German................

Raphanus Raphanistrum..... 32

Rattle Weed............ 22

\section{PAGE}

136

139

137

119

102

40

40

41,47

41,48

47

47

41,46

73

74

74

73

106

107

106

106

106

148

146

131

73

74

111

74

94

90

90

67

152

149

150

153

152

150

160

160

134

75

77

76

77

93

93

93

90

70
Plate Page

Red Root. ............. 127

Rhinanthus Crista-galli..... . . 133

Ribgrass............. $52 \quad 138$

Ribwort Family. . . . . . . . . 135

Ribwort............. $52 \quad 138$

Rock Cresses. ............. 101

Rocket................. 94

Prairie. .............. 101

Salad. ................ . 94

Yellow............... 101

Rosa acicularis, var. Bour-

geauiana.............. 104

arkansana............. 103

pratincola.............. 103

ROSACEAE........... 103

Rose Family............. 103

Rose (St. Johns-wort) . . . . . $41 \quad 112$

Roses, Prairie............. 103

Rose Moss............... . 73

Rosin..............41 412

Rotation of Crops, Short. ... . $\quad 17$

Rough Weed........... $49 \quad 132$

RUBIACEAE.......... 140

Rudbeckia hirta.......... $58 \quad 154$

Rumex.............. 40

Acetosa .............. $\quad 45$

Acetosella............. $10 \quad 44$

conglomeratus........... . 43

crispus............. $9 \quad 42,43$

obtusifolius. ............. 43

venosus.............. 43

Rush Family........... 40

Rush, Slender............. 40

Rutabaga.............. 93

Sage Brushes. . . . . . . . . . . . 159

Lesser Pasture. . . . . . . . . . . 159

Pasture. .............. . 159

Swect............... . . 159

Salsify................ 169

Salsola................. . 50

Salsola Kali, var. tenuifolia. . $15 \quad .54$ var. Tragus.... 15 ' 54

Tragus............. $15 \quad 54$

Sandweed. ............. $17 \quad 60$

Saponaria.............. $\quad 59$

officinalis............. . 73

Vaccaria............ $23 \quad 72$

Savastana odorata ....... 2

Scarlet I.ightning. . . . . . . . 67 
SCROPHULARIACEAE. . . . 133

Scutch.............. 6

Sedge Family . . . . . . . . . . 39

Sedge, Awned............... 39

Sedum purpureum........ . . 103

Seeding to Grass. . . . . . . . . . $\quad 18$

Self-heal. .............. 131

Senecioneae............. 160

Senecio Jacobaea. . . . . . . . 61 viscosus. ................ vulgaris.

Setaria glauce ............. viridis............. 1

Sheep destroy Weeds. . . . . . ...

Shepherd's Purse. ......... 29

Sherardia arvensis. ..........

Sida spinosa..............

Sileneae.................

Silene .................

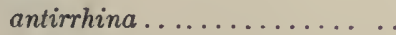

Armeria................

conica.

Cucubalus............ 22

gallica...............

inflata. ........... 22

latifolia............ 22

noctiflora............ 21

pratensis........... 20

vulgaris. ............ 22

Silkweed. . . . . . . . . . . . . . . .

Silkweeds. . . . . . . . . . . . . .

Silverweed. .............. .

Sinapis arvensis. . . . . . . . 33

Sisymbrium, Tall. ........ 35

Sisymbrium altissimum..... 35 incisum, var. Hartuegianum .. var. filipes...... 36 officinale.............. pannonicum.......... 35 sinapristrum. ......... 35

Skeleton Weed. .............

Smartweed. ............ 11

Smartweeds. ..............

Snakeroot, White. .........

Snapdragon, Wild..........

Sneezeweed. ..............

Solidago canadensis.......... . graminifolia.......... 53 lancealata............ 53 rugosa.

(1)

8

160
160

161

161

25

Plate Page

serotina.............. 145

Sonchus arvensis. . . . . . . $66 \quad 170$ asper................ . 173 oleraceus............667 67 pulchellus............69 $69 \quad 176$

Sophia incisa. . . . . . . . . $36 \quad 98$

Sorrel, Field........... $10 \quad 44$

Garden. .............. . 45

Red.............. $10 \quad 44$

Sheep. .............. $10 \quad 44$

Sour-grass. ............ $10 \quad 44$

Speedwells............... 133

Spergula arvensis. . ....... $17 \quad 60$

Spider-flower. ............ 102

Spinach Family........... 50

Spiny Sida............... 111

Spiraea sulicifolia........... 105

tomentosa............ $38 \quad 104$

Spurge Famil............. 110

Spurge, Flowering. .......... 111

Ridge-seeded. ............ 111

Sun................. 110

Spurrey............ $17 \quad 60$

Corn............ $17 \quad 60$

St. James'-wort. . . . . . . $61 \quad 160$

St. John's-wort Famul . . . . . 112

St. John's-wort, Common . . $41 \quad 112$

Corymbed............. 113

Great............... . 113

Pale................ 113

Spotted.............. 113

Stachys palustris. . . . . . . $49 \quad 132$

Staggerwort,........... $61 \quad 160$

Steeple Bush........... $38 \quad 104$

Stellaria graminea.......... . 63 media............... $18 \quad 62$

Stickseed............. $46 \quad 124$

Stickweed. . . . . . . . . . $46 \quad 124$

Virginian.............. 125

Stinking Willie.......... $61 \quad 160$

Stinkweed........... $27 \quad 80$

Stitchwort, Grass-leaved. . . . . 63 Lesser................ 63

Succory, Wild.......... $64 \quad 166$

Summer Fallowing. . . . . . . . 15

Sirnflower Family......... 141

Sunflower, Black-headed. . . . . 154

False................ 155

Prairie, Many-flowered ... .. 155

Wild................. 154 


\begin{tabular}{|c|c|c|c|c|}
\hline & Plate & PAGE & Plate & PAGE \\
\hline Swinies. . & 67 & 172 & Vernonieae.. . & 142 \\
\hline Tanacetum vulgare. ........ & . & 159 & Vernonia. & 142 \\
\hline Tansy, Common........... & . $\ldots$ & 159 & Veronica. . & \\
\hline False. . . . . . . . . . . & . $\cdots$ & 159 & Vervain Family. . & \\
\hline Taraxacum erythrospermum. . & - $\cdots$ & $\begin{array}{l}169 \\
169\end{array}$ & Vervain, Blue...... & \\
\hline $\begin{array}{l}\text { officinale } \ldots \ldots \ldots \ldots \ldots \\
\text { Tare, Cultivated. . . . . . . }\end{array}$ & $\cdots$ & $\begin{array}{l}169 \\
109\end{array}$ & Narrow-leaved... & \\
\hline wild................ & 40 & 108 & White. . . . . . . & 128 \\
\hline Thapsus................ & . & 133 & Vetch, Common. ........ 40 & 108 \\
\hline Thermopsis............. & . & 107 & Hairy................ & 110 \\
\hline Thistle, Bull. ............ & . & 165 & Spring. ............... & 109 \\
\hline Western. ....... & & 165 & Tufted, Purple . ......... . & 109 \\
\hline Canada............... & . 63 & 164 & Wild.............. 40 & 108 \\
\hline Creeping. . ............ & 63 & 164 & 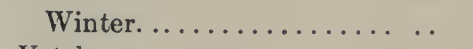 & \\
\hline Field, Soft . ........... & 63 & 164 & Vetches................. & \\
\hline Milk. ............. & 67 & 172 & Milk . . . . . . . & 08 \\
\hline Prairie............... & . . & 165 & Vicia angustifolia.........40 40 & \\
\hline Russian. ............. & 15 & 54 & 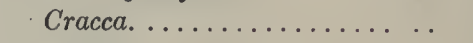 & 109 \\
\hline “ $\quad$ (misnamed)..... & 66 & 170 & sativa............. & 109 \\
\hline Sow, Annual............. & 67 & 172 & Villosa............. & 110 \\
\hline Common ............ & 67 & 172 & & \\
\hline Corn $\ldots \ldots \ldots \ldots \ldots$ & 66 & 170 & Wallflower, Western........ & 101 \\
\hline Creeping. . . . . . . . . . & 66 & 170 & Wax-ball. ............ & 110 \\
\hline Field ............... & 66 & 170 & Weed, what is a. ........... & 8 \\
\hline Perennial. . . . . . . . . . & 66 & 170 & Weeds, classification of. . . . . . & 10 \\
\hline Prickly ............. & . & 173 & control and extermination of .. & 13 \\
\hline Spiny-leaved. . . . . . . . & & 173 & distributed in space....... & 12 \\
\hline Spear. .............. & & 165 & in time...$\ldots \ldots \ldots \ldots$ & 1 \\
\hline Weed Milk. . . . . . . . . . . & 68 & 174 & how they spread. . ........ . & 0 \\
\hline Thlaspi arvense.......... & 27 & 80 & losses due to $\ldots \ldots \ldots \ldots$ & \\
\hline Bursa-pastoris. . . ...... & 29 & 84 & Weed seeds in commercial & \\
\hline Tiniaria................ & & 41 & seeds and feeding stuffs .. & 21 \\
\hline Toad Flax............... & 50 & 33,134 & Weed seeds in the soil.. ..... & 12 \\
\hline 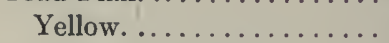 & 50 & 134 & Wheat Thief (Chess)....... & 30 \\
\hline Tragopogon porrifolius. . .... & $\therefore$ & 169 & " " (Pigeon Weed). .. & 127 \\
\hline pratensis. ................ & $\cdots$ & 169 & White Bottle. . . . . . . . 22 & 70 \\
\hline Trefoil, Yellow............ & .. & 108 & White Weed. ........... 60 & 158 \\
\hline Trifolium arvense. ......... & . & 107 & Willow-herbs. ........... & 113 \\
\hline Triticum repens. . . . . . . . . & 6 & 34 & Willow-herb, Great......... . & 113 \\
\hline Tubuliflorae. ............ & .. & 142 & Winter annuals. . .......... & 11 \\
\hline Tumble Weed............ & .. & 58 & Wormwood, Roman. ...... 57 & 152 \\
\hline Russian. ............... & 15 & 54 & Wormwoods............. & 159 \\
\hline Turnip. . & . & 93 & Woundwort. . ......... 49 & 132 \\
\hline Wild................... & $\ddot{32}$ & 90 & Woundwort, Clown's....... 49 & 132 \\
\hline Twitch................ & 6 & 34 & Xanthium. .. & 153 \\
\hline UMBELLIFERAE. . . . . & . & 115 & 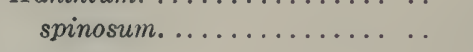 & 153 \\
\hline Vaccaria Vaccaria.......... & 23 & 72 & Yarrow. ....... & 157 \\
\hline vulgaris. .............. & 23 & 72 & Yellow Rattle. ............. & 133 \\
\hline VERBENACEAE....... & .. & 128 & Yellow Star. . . . . . . . . . . & 155 \\
\hline Verbena angustifolia. ....... & .. & 128 & Yellow-weed (Ball Mustard).. 31 & 88 \\
\hline hastata. .................... & . & 128 & Yellow Weed (Yellow Rocket).. & 101 \\
\hline urticaefolia. ............ & .. & 128 & " " (Goldenrod)...53 & 144 \\
\hline
\end{tabular}




SB

613

$\mathrm{C}_{2} \mathrm{~A}_{4}$

1923

cop.2
Canada. Dept. of Agriculture

Farm weeds of Canada $2 d$ ed., rev. and enl.

\section{Botany}

PLEASE DO NOT REMOVE CARDS OR SLIPS FROM THIS POCKET

UNIVERSITY OF TORONTO LIBRARY 


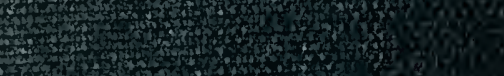

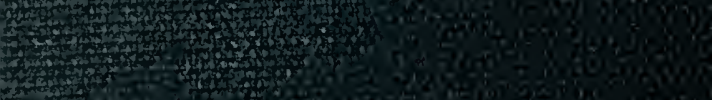

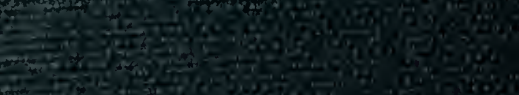

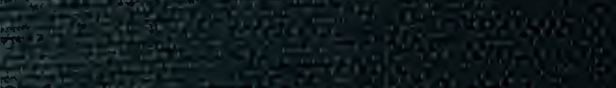

